\title{
SOME ARGUMENT-STRUCTURE PROPERTIES OF 'GIVE' IN THE LANGUAGES OF EUROPE AND NORTHERN AND CENTRAL ASIA
}

\author{
BERNARD COMRIE \\ Max Planck Institute for Evolutionary Anthropology \& \\ University of California Santa Barbara
}

Haspelmath (forthcoming) provides a typology of the expression of the object arguments of the verb 'give' using three basic types, according to whether the recipient, the gift, or neither is overtly marked differently from patients of monotransitive verbs:

indirect object, e.g. 'Mary gives the book to John'

primary object, e.g. 'Mary gives John with the book'

double object, e.g. 'Mary gives John the book'

In addition, he allows a mixed type for languages that permit more than one of these types, such as English, which has both indirect object and double object constructions. A quick glance at the map accompanying his text shows that Europe and Northern and Central Asia are dominated by the indirect object type, with exceptions being largely geographically peripheral or, as in the case of Ket, in a language that is otherwise typologically unusual for its location: For instance, the primary object type is found in Nivkh, the double object construction in Ainu and Ket, and the mixed type in English (and in some other neighboring Germanic languages not included in Haspelmath's sample).

While not challenging Haspelmath's basic finding, and indeed in part following up on passing observations made by Haspelmath, this paper aims to show that consideration of a broader range of morphosyntactic features than just the overt marking of recipient and gift leads to a more differentiated picture of argument-structure properties of 'give' in what otherwise seems a very homogeneous area. In particular, many languages show features that indicate a less marked, morphosyntactically more central status of the recipient. Properties to be discussed include the following:

a) Differences between full noun phrases and pronouns as object arguments of 'give', as when Maltese has the double object construction with pronoun objects, alongside the indirect object construction elsewhere.

b) Verb-object agreement, including the use of resumptive pronouns, which often gives preference to resumptive dative pronouns agreeing with the recipient over resumptive accusative pronouns agreeing with the gift, as in Spanish.

c) Passive verb forms, which may give preference to promotion-to-subject of the recipient rather than of the theme, in the indirect object construction (e.g. Japanese) and in the double object construction (e.g. English).

d) Constituent order, with the possibility of having the recipient rather than the gift closer to the verb in the double object construction (e.g. English, Mandarin Chinese) and perhaps even in the indirect object construction.

e) Stem suppletion according to features of the recipient rather than of the gift, as in Old Basque, Tsez (East Caucasian family), Yukaghir, and Japanese.

\section{REFERENCE}

HASPElmath, MARTIN. Forthcoming. Ditransitive constructions: the verb 'give'. In Matthew Dryer, Martin Haspelmath, David Gil, and Bernard Comrie (eds.), The World Atlas of Language Structures. Oxford: Oxford University Press. 


\title{
PATTERNS OF ASYMMETRY IN ARGUMENT STRUCTURE ACROSS LANGUAGES: SOME PRINCIPLES AND PUZZLES
}

\author{
JOHN A. HAWKINS \\ University of Southern California \& \\ Max Planck Institute for Evolutionarly Anthropology Leipzig
}

Many cross-linguistic generalizations reveal asymmetries between the different arguments of multiargument predicates. The asymmetries are visible in syntactic processes such as relativization or reflexivization (argument A may undergo rule R, argument B does not); in linear ordering (argument A is preferred before B, not vice versa); and in surface coding (argument A is coded morphosyntactically, argument B is not, and/or argument A is coded using less phonological material than B). These asymmetry rankings have been captured in the form of hierarchies of grammatical relations, hierarchies of morphological cases and verb agreement, hierarchies of thematic roles, and in linear precedence preferences (cf. e.g. Greenberg 1966, Keenan \& Comrie 1977, Primus 1999, Siewierska 1988). The paper raises the question: why should there be such consistent rankings and asymmetries among the arguments of a predicate? It proposes some partial answers using the principles of efficiency and complexity developed in Hawkins $(2003,2004)$, argues against some proposals that have been made in the literature, and takes note of the phenomena that are still puzzling from this point of view. A wide range of languages will be considered in presenting these patterns of asymmetry, including many from Europe and North and Central Asia.

\section{REFERENCES}

GreEnBerg, J.H. 1966. Language Universals, with Special Reference to Feature Hierarchies. The Hague: Mouton.

HAWKINS, J.A. 2003. Efficiency and complexity in grammars: three general principles. In J. Moore, and M. Polinsky (eds.), The Nature of Explanation in Linguistic Theory, 121-152. Stanford, CA: CSLI Publications,

HAWKINS, J.A. 2004. Efficiency and Complexity in Grammars. Oxford: Oxford University Press.

KEENAN, E.L., and B. Comrie. 1977. Noun phrase accessibility and Universal Grammar. Linguistic Inquiry 8: 63-99.

PRIMUS, B. 1999. Cases and Thematic Roles: Ergative, Accusative and Active. Tuebingen: Max Niemeyer Verlag.

SIEWIERSKA, A. 1988. Word Order Rules. London: Croom Helm. 


\title{
PYRAMIDS OF TOPOGRAPHICAL RELATORS IN NORTHEASTERN TURKIC AND ITS NEIGHBOURS
}

\author{
LARS JOHANSON \\ Johannes Gutenberg University Mainz, Mainz
}

The paper will deal with the domain of basic topological relations in older and recent stages of languages of the northeastern area of distribution of Turkic, i.e. Siberia and Mongolia. It will discuss topographical relators that describe physical scenarios, expressing different kinds of contiguity and coincidence, i.e. spatial notions such as inclusion ('in', 'inside'), superposition ('on', 'over'), subposition ('under'), circumposition ('around'), exteriority ('outside'), contraposition ('against'), prosecution ('along'), intermediacy ('between'), laterality ('beside'), proximity ('near'), etc. Another relevant variable is the difference between static ("essive") functions ('in', 'on', etc.) and dynamic functions expressing direction ('into', 'onto', 'from inside', 'from outside', etc.).

It will be argued that the northeastern Turkic languages exhibit several layers of topological relators representing different stages of grammaticalization. The oldest layer consists of rather general, undifferentiated locative relators, residual categories that cover several potential basic notions in the topological domain. Thus the simple East Old Turkic "locative-ablative" case marker is used for static and dynamic spatial situations encompassing adherence, attachment, inclusion, superposition, etc. ('at', 'in', 'on', 'from', 'out of').

There is a second layer of relators, which is partly found in East Old Turkic already, a small set of old adpositions representing less advanced stages of grammaticalization and conveying more specific relations ('over', 'up to', 'towards', 'between', 'beyond', 'through', 'across').

There is finally a third layer of relators which develop later and differentiate the systems further, spatial adpositions with still more specific meanings. They are typically locative nouns ('interior', 'back', 'side', 'top', 'bottom', etc.) assuming locative case markers.

The relators of each successive layer convey more fine-grained meaning differences, the more specific terms functioning as hyponyms of the more general ones. The development is thus pyramidlike, departing from an undifferentiated "apex", proceeding over regularly sloping sides, and ending in a polygonal base of clearly differentiated relators.

Relics of the older less differentiated systems are found in the argument structure of a small set of basic positional verbs, 'sit', 'settle', 'go', etc., with which spatial nouns are used as direct objects, e.g. East Old Turkic yazï qon- 'to settle (down on the) plain'.

The paper will also address questions of possible contact influences between the Turkic languages of the area and varieties of Mongolic, Tungusic, and Paleosiberian. In this connection it will also discuss special language-specific topographical notions depending on geographical positions or cultural conditions, such as 'downstream', 'upstream', etc. 


\title{
КОГНИТИВНОЕ РАЗНООБРАЗИЕ ПРЕДИКАТНО-АРГУМЕНТНЫХ СТРУКТУР И ЯЗЫКОВЫЕ СТРАТЕГИИ ИХ УНИФИКАЦИИ
}

\author{
АЛЕКСАНДР ЕВГЕНЬЕВИЧ КИБРИК \\ Московский государственный университет им. М.В. Ломоносова, Москва
}

1. Известно, что наряду с привычной европейскому языковому сознанию аккузативной конструкцией, лежащей в основе базового предложения, в различных ареалах мира представлены также эргативная, активная и трехчленная конструкции. Изучение этих конструкций приводит к выводу, что синтаксическое разнообразие структуры базовых предложений в естественных языках не сводимо к синтаксическим концептам подлежащего и дополнения, отражающим прежде всего структуру аккузативной конструкции. Если это так, то сами концепты полежащего и дополнения не являются первичными и универсальными, а образуются из более элементарных концептов.

Более того, во многих языках обнаруживаются базовые предложения, явным или скрытым образом отклоняющиеся от доминирующей в языке (канонической) синтаксической конструкции и реализующие некоторые особые неканонические конструкции ${ }^{l}$. Неканоничность этих конструкций может выражаться непосредственно в их кодирующей технике или проявляться в особенностях их синтаксического поведения.

2. Я исхожу из тезиса, что языковые структуры являются наблюдаемыми коррелятами когнитивных структур и мотивированы ими. Поэтому когнитивные структуры могут быть реконструированы по языковым данным и особенно по данным о языковом варьировании в кодировании идентичных когнитивных структур.

Вслед за Чейфом правомерно считать, что строительным материалом когнитивной структуры являются представления (ideas по [Chafe 2002]) о ситуациях и их партиципантах. Вообще говоря, каждая ситуация является уникальной, в том числе и с точки зрения ролевых характеристик еe партиципантов. Однако естественные языки предоставляют нам свидетельства их последовательной когнитивной генерализации. Можно выделить, по крайней мере, следующие типы представлений ${ }^{2}$ :

\section{Ситуации}

процесс (идти, падать, лететь, расти, спать) действие (делать, убивать, портить, одевать) мысль (думать, говорить, решать, полагать) чувствование ${ }^{3}$ (видеть, знать, быть холодно; любить, хотеть, быть весело; забывать, находить) обладание (иметь, принадлежать, иметься) локализация (быть, находиться) дескрипция ${ }^{4}$ (быть [большим, студентом, дураком]) существование (быть, существовать) отождествление (означать то же самое, что) называние (зовут, называться)

\author{
Партиципанты \\ Процессант \\ Агенс, Пациенс \\ Говорящий, Содержание \\ Экспериенцер, (Стимул) \\ Посессор, Обладаемое \\ Локализуемый, Место \\ Сущность, Дескриптор \\ Сущий \\ Означающее, Означающее \\ Означаемое, Означающее
}

\footnotetext{
${ }^{1}$ Проблема неканонических конструкций поднята в [Aikhenvald and Dixon (eds.) 2001], хотя там точкой отсчета являются универсальные концепты субъекта и объекта, а не конкретно-языковая каноническая конструкция.

${ }^{2}$ Основанием для их выделения является наличие особых типов конструкций в различных языках.

${ }^{3}$ В этом типе объединяются восприятие, эмоции и ментальные состояния.

${ }^{4}$ В этом типе объединяются предложения таксономии (Он большой), характеризации (Он студент) и оценки (Он дурак).
} 
3. В принципе эти ситуации онтологически первичны и не сводимы друг к другу ${ }^{5}$. У каждой ситуации свой набор ядерных партиципантов и характеризующих их ролей (иными словами, по комбинациям ролей партиципантов однозначно определяется тип ситуации). Языковое кодирование этих представлений может быть основано на различных тенденциях, полярными из которых являются следующие:

ПРЕДЕЛЬНО РАЗЛИЧИТЕЛЬНАЯ ТЕНДЕНЦИЯ: - У КажДОЙ ТИПОВОЙ СИТУацИИ имеется спецИфическое ролевое кодирование ее партиципантов;

ПРЕДЕЛЬНО НЕРАЗЛИЧИТЕЛЬНАЯ ТЕНДЕНЦИЯ: - тИПОВЫе ситуацИи (и их партиципантЫ) на языковом уровне не различаются.

Есть все основания считать, что языки не приемлют первую альтернативу как экономически бесперспективную (напомним, что выделение типовых ситуаций уже является обобщением бесконечного многообразия ситуаций).

Вторая альтернатива многим кажется маловероятной (как в таком случае различать партиципантов, если их в ситуации более одного?), однако она не может быть исключена, поскольку частичное неразличение участников встречается во многих языках, см., например, неразличение номинатива и аккузатива в некоторых склонениях в латинском или русском языках, что приводит к предложениям типа: Болящий дух врачует песнопенье, где, несмотря на падежную омонимию, нерелевантность признака одушевленности и инвертированный порядок слов, прагматически однозначно восстанавливается смысл предложения (врачуют то, что болит). Согласно исследованиям Д.Гила [Gil 1994], риау индонезийский не различает ролей партиципантов. Такой язык реализует нейтральную конструкцию элементарного предложения.

Компромиссной альтернативой является следующая:

МИНИМАЛЬНО РАЗЛИЧИТЕЛЬНАЯ ТЕНДЕНЦИЯ: - коДИрОваНИе роЛеЙ дЛЯ всеХ/МНОГИХ ТИПОВЫХ ситуаций обеспечивается минимальным набором обобщенных ролей (гиперролей) с соблюдением принципов экономичности, различительности и семантической мотивированности.

Абсолютное большинство языков следуют этой тенденции. Эта тенденция, существенно ограничивая структуру естественных языков, тем не менее она имеет достаточно много степеней свободы. Это касается как выбора канонической конструкции, так и степени охвата ею типовых ситуаций.

4. Когнитивно естественной является генерализация по выделенному прототипу. Языки, использующие стратегию унификации синтаксической конструкции, обычно берут за прототипическую основу действия, поскольку последние имеют два ядерных партиципанта (Агенс и Пациенс), нуждающихся в идентификации. Генерализация при этом в первую очередь распространяется на процессы (имеющие только один ядерный аргумент - Процессант). Имеется четыре семантически мотивированных альтернативы: 1) раздельное кодирование Агенса, Пациенса и Процессанта (трехчленная конструкция), 2) уподобление Процессанта Агенсу с образованием гиперроли Принципала (аккузативная конструкция), 3) уподобление Процессанта Пациенсу с образованием гиперроли Абсолютива (эргативная конструкция), 4) различение агенсоподобных и пациенсоподобных Процессантов с образованием гиперролей Актора и Претерпевающего (активная конструкция). Более подробное обоснование см. в [Kibrik 1997, Кибрик 2003: 109-187].

Агенс и Пациенс могут быть источником дальнейшего метонимического расширения на участников других ситуаций. Так, для ситуации чувствования обычным (хотя не обязательным, см. ниже) является объединение Экспериенцера с Агенсом и Стимула с Пациенсом. В аккузативной конструкции Экспериенцер вместе с Агенсом входит в гиперроль Принциапала, а Стимул с Пациенсом - в гиперроль Пациентива. В эргативной конструкции Стимул с Пациенсом объединяются в гиперроли Абсолютива, а Экспериенцер с Агенсом - в гиперроли

\footnotetext{
5 Это не исключает наличия композиционных предикатов типа появляться, исчезать (процесс + существование), сидеть, лежать (процесс + наличие свойства) и т.п.
} 
Агентива. В трехчленной конструкции Экспериенцер с Агенсом образуют гиперроль Агентива, а Стимул с Пациенсом - гиперроль Пациентива. В этом случае Процессант объединяется с ролями участников других одноместных ситуаций в гиперроли Единственного.

Следует отметить, что подлежащее также является гиперролью (это наиболее выделенный, наиболее важный, наиболее обязательный участник ситуации), которая в принципе может быть расширением гиперролей Принципала, Абсолютива или Единственного, хотя наиболее широко засвидетельствован первый тип расширения. Ядерные синтаксические отношения (субъект, объект) в тех языках, в которых они грамматикализованы, являются наиболее наиболее обобщенным способом представления структуры базового предложения.

5. Таким образом, все гиперроли имеют когнитивную мотивацию, поэтому для языков, следующих минимально различительной стратегии унификации, существует возможность выбора того или иного набора гиперролей как мишеней грамматикализации. Иными словами, некоторые гиперроли реализуются в языке в явном виде. Они задают каноническую конструкцию элементарного предложения. Однако это не значит, что прочие гиперроли не существуют в языке в скрытом виде. Имеются универсальные контексты, гармонирующие с той или иной гиперролью.

Например, контекст императивного предложения гармонирует с гиперролью Актора, а контекст дистрибутивного распределения события по многим участникам гармонирует с гиперролью Абсолютива. Так, в языках, чувствительных к гиперролям, императив от глаголов, не имеющих агентивнго партиципанта (например, умирать, видеть), невозможен (багвалинский). В русском языке дистрибутив возможен только в отношении Абсолютива (время разбрасывать камни, дети разбежсались, родители поумирали).

Абсолютив также гармонирует с дискурсивной категорией «attention-worthiness» [Mithun 1993].

То же можно сказать об инкорпорации аргумента при номинализации глагола: в отглагольное имя инкорпорируется Претерпевающий, но не Актор (см. русское 6 кофеварка [из варят кофе], снегопад [из снег падает]; аналогично ограничение на инкорпорацию в алюторском языке).

Широко известна дискурсивная корреляция Принципала с топиком, автономной референтностью и фокусом эмпатии.

6. Языки находятся на разных ступенях унификации типов ситуаций. Многие языки сохраняют различия, существующие между различными ситуациями. Особенно распространены неканонические конструкции для выражения ситуаций чувствования (аффективная конструкция) и обладания (посессивная конструкиия). Весьма часто не укладываются в прокрустово ложе канонической конструкции также ситуации локализащии, существования, дескрипчии, отождествления и называния. Специфические особенности могут иметь конструкции, обозначающие ситуацию мысли.

\section{ЛИТЕРАТУРА}

КИБРИК А.Е. 2003. Константы и переменные языка. СПб: Алетейя.

AiKHENVALD, ALEXANDRA AND R.M.W.DiXON. 2001. Non-canonical marking of subjects and objects. Amsterdam: Benjamins.

Chafe, Wallace. 2002. Putting grammaticalization in its place. In Wischer, Ilse, and Gabriele Diewald (eds.), New reflections on grammaticalization, 395-412. Amsterdam: Benjamins.

GIL, DAVID. 1994. The structure of Riau Indonesian. Nordic journal of linguistics 17. 179-200.

KIBRIK, ALEKSANDR. 1997. Beyond subject and object: Toward a comprehensive relational typology. Linguistic typology 1. 279-346.

Mithun, MarianNe. 1993. The implication of ergativity for a Philippine voice system. In Fox, Barbara. and Paul J.Hopper (eds.), Voice, form, and function, 247-277. Amsterdam: Benjamins.

\footnotetext{
${ }^{6}$ Кроме Абсолютива в русском языке может инкорпорироваться также Место и Инструмент: снегоход [из: ходит по снегу], солнцелечение [из: лечить солнцем].
} 


\title{
COGNITIVE DIVERSITY OF THE PREDICATE-ARGUMENT STRUCTURES AND THE LINGUISTIC STRATEGIES OF THEIR UNIFICATION
}

\begin{abstract}
ALEKSANDR E. KIBRIK
Moscow State University

At least the following types of situations, as conceptualized in verbs, must be distinguished: process, action, thought, feeling, possession, localization, description, existence, identification, and naming. Each of these types has a unique set of participant roles. In principle, these roles are fundamental and irreducible to each other. However, languages present many cases of their generalization or likening. Since linguistic structures constitute visible reflections of the cognitive representations, these processes of generalization or likening must be taken as signals of the underlying cognitive processes. The fully distinctive strategy is rarely found in languages, as well as the fully neutralizing strategy. Many intermediate strategies are actually found in languages, in particular the minimally distinctive strategy: role coding is performed by a minimal set of generalized hyperroles, which conforms to the principles of economy, distinctiveness, and semantic motivation. Generalization means relying on one type of situation, with its participant role, as the basis, and representing other types of situations as analogical extensions. For instance, the Experiencer of the feeling situation type can be generalized with the Agent of the action situation type. The subject/object systems (in languages that have these categories) are a common example of the minimally distinctive strategy. All hyperroles have a cognitive motivation, and this applies to covert hyperroles, too. For example, in Russian the distributive meaning is compatible only with the Absolutive hyperrole that is not explicitly represented by the coding devices.
\end{abstract}




\title{
THE POTENTIAL INSTABILITY OF GRAMMATICAL RELATIONS
}

\author{
MARIANNE MITHUN \\ University of California, Santa Barbara
}

In stimulating work on deep genetic relations, Nichols $(1990,1992)$ has proposed that the categorization of core arguments has high genetic stability over time. It should serve, accordingly, as a useful guide in solving 'problems of detecting affinity at great time depths and describing early linguistic prehistory' (Nichols 1992:1). Examples certainly abound of such stability within certain language families. Numerous examples can also be found, however, of shifts at relatively shallow time depths. Here we will examine shifts to various types of patterns, some widely known (Nominative/Accusative, Ergative/Absolutive), and others less familiar (Agent/Patient, Hierarchical Inverse). It will be seen that both language-internal and language-external factors may stimulate and facilitate the shifts, often acting in concert. The fluidity of these systems suggests that the codification of grammatical relations and argument structure may not be a reliable indicator of deep genetic relationship after all. It may, to the contrary, suggest the influence of contact.

Diachronic shifts to Nominative/Accusative and Ergative/Absolutive patterns may be brought about by several different mechanisms. Among them are the generalization of passive or antipassive constructions, the reanalysis of instrumental constructions, and the extension of possessed nominalized clauses to main clause status. Since such processes have already been discussed elsewhere, shifts of this type will be surveyed briefly.

The next type of shift to be discussed is to the Agent/Patient type. Though not as common as some others, such systems have been observed in most areas of the world. In North America they cover a wide, contiguous area of the Northeast, Southeast, and Great Plains, but they appear in only a few small points elsewhere. One of these is the Yuki language of Northern California. Yuki has traditionally been classified as remotely related to just one other language, Wappo, though that relationship remains controversial. Wappo distinguishes Subject and Object categories, but Yuki has grammaticalized Agent and Patient categories, distinguished in pronoun shape and case endings on nouns referring to humans. Semantic agents of verbs like 'run', 'eat', or 'hit', for example, are categorized as grammatical Agents, while participants affected by such events as 'hit', 'fall, or 'die', or by such states as 'fear', 'be tired', or 'be in pain' are categorized as grammatical Patients. The crucial features underlying the categorization are not aspect (as in Active/Stative systems), nor instigation or performance (as in some other Agent/Patient systems), but control and affectedness. Verbs like 'hiccup' or 'vomit', performed but uncontrolled, appear with grammatical Patients. The distinction is made only for humans, and in some cases not even for them, particularly for third persons. A system with just these characteristics is rare cross-linguistically, but it is found in the immediately adjacent languages of the Pomoan family. All seven Pomoan languages share precisely these features, though the forms involved show no similarity whatsoever. No genetic relationship has ever been seriously considered between Yuki and Pomoan. There has, however, been longstanding, extensive intermarriage among Yuki and Pomoan speakers, with a strong tradition of multilingualism, suggesting that the system came into being through contact. The abstract pattern was apparently borrowed but not on the markers themselves. The mechanism underlying the shift is easy to reconstruct. In Yuki, as in Pomoan, pronouns are independent words rather than affixes, but third persons are not normally identified at all if their reference is clear. A sentence like '(It) tires me' could thus be rendered with just a verb and Patient pronoun 'me'. Transitivity is not marked on verbs, so it would be an easy matter to reanalyze the indigenous transitive '(It) tires me' (1.patient tired) as an intransitive 'I am tired'. The original object pronoun 'me' could be reinterpreted as a Patient pronoun. There are few syntactic constructions that distinguish a subject relation in either language. Yuki contains no passives, for example, though there are derivational suffixes that can be used to form new verb stems for specifically deliberate or involuntary actions. The Pomoan languages contain a derivational detransitivizer that affects argument structure, eliminating an Agent argument from transitive verb stems, but the remaining argument shows no change in grammatical status: it is still a grammatical Patient. The Yuki case provides a good example of a system shift stimulated and shaped by contact, but developed through language-internal reanalysis. 
The last shifts to be examined are to Hierarchical systems. In the systems considered here, core arguments are identified on verbs by pronominal affixes. In intransitive clauses, the single core argument is always specified pronominally. In transitive clauses, only one of the two arguments is represented. The choice of argument to represent is determined primarily by person, though other factors may be in play as well. Typically in clauses with a first or second person acting on a third $(1 / 3,2 / 3)$, only the first or second person is represented ( 1 or 2$)$. In clauses with a third person acting on a first or second, again it is the first or second person that is represented, usually with some indication of the role of that argument (1-x or 2-x). Such systems occur in various parts of the world, though they are comparatively rare. A concentration of such systems can be found, however, in a set of areally contiguous languages in Northern California. Among them are the closely-related Yanan languages, the isolate Chimariko, the isolate Karuk, the Yurok language of the Algic family, and to a lesser extent the neighboring Palaihnihan and Shasta languages. One might be tempted to suggest that the similarities reflect a very deep genetic relationship, deeper than one retrievable through the comparative method. The development of the systems can be seen to be relatively recent in each of the languages, however. Furthermore, they can be seen to have evolved from slightly different kinds of systems through slightly different mechanisms. The Yanan systems, for example, can be seen to have arisen relatively recently in several stages from a Nominative/Accusative system, through an increase in passivization. The Chimariko system can be seen to have arisen from an Agent/Patient system, facilitated by the lack of affixes representing third persons. Each of the systems and their histories will be described. The situation suggests that the development of the systems was originally stimulated by contact in an area known for long-term, heavy multilingualism, but that the particular pathways by which each evolved was dependent on different circumstances in each language.

In the end, the fluidity of each of these system types suggests that the codification of grammatical relations and argument structure should not be taken prematurely as an indication of deep genetic relationship.

\section{REFERENCES}

NiCHOLS, JOHANNA. 1990. Linguistic diversity and the first settlement of the New World. Language 66: 475-521.

NiCHOLS, JOHANNA. 1992. Linguistic diversity in time and space. Chicago: University of Chicago Press. 


\title{
РЕЦИПРОКАЛЬНЫЕ КОНСТРУКЦИИ В ТЮРКСКИХ ЯЗЫКАХ (ТИПОЛОГИЧЕСКАЯ ХАРАКТЕРИСТИКА)
}

\author{
ВЛАДИМИР П. НЕДЯЛКОВ \\ Российская академия наук (РАН), Институт лингвистических исследований, \\ Санкт Петербург
}

1. Рассматриваются некоторые семантические и синтаксические особенности реципрокальных (взаимных) конструкций в ряде тюркских языков и на типологическом фоне ряда языков других семей.

Реципрокальной именуется конструкция, содержащая либо реципрокальный суффикс -ш (или $-c)$ в составе глагола, либо приглагольное реципрокальное местоимение типа якутского бейе-бейе-лери-н со значением 'друг друга' (для северо-тюркских языков; типа бири-бири-н для остальных). Эти реципрокальные местоимения однозначны, тогда как реципрокальный суффикс многозначен. Так, например, тувинская форма (1) и́nте-ш- может иметь следующие четыре значения: (а) реципрокальное - 'грабить друг друга', (б) социативное - 'грабить когол. вместе', (в) комитативное - 'вместе с кем-л. грабить кого-л.' и (г) ассистивное - 'помогать кому-л. грабить кого-л.' (K. Kuular, в печати). Общим для всех этих четырех значений является то, что в каждой из называемых ситуаций действие, обозначенное исходным глаголом, совершается двумя или более лицами. Своеобразие реципрокального суффикса заключается в том, что он может воздействовать на синтаксические свойства деривата тремя возможными способами: в случае (а) валентность глагола уменьшается, в случае (б) валентность сохраняется, а в случаях (в) и (г) она увеличивается (в случае (а) валентность тоже может сохраняться, если оба участника ситуации называются разными членами предложения - подлежащим и косвенным дополнением).

Судя по специальной литературе, такой набор значений у реципрокального показателя пока не отмечен в других языках мира, за исключением ареально близких монгольских языков (суффиксы -лда и -лца/-лса; Г. Санжеев 1963). Названные четыре значения реципрокальный показатель имеет и не во всех тюркских языках. Полисемия показателя, включающая все четыре значения, характерна для таких языков как якутский, татарский, тувинский, туркменский, казахский, и не наблюдается, например, в турецком, азербайджанском, карачаево-балкарском, где нет ассистивного значения (см. также Э. Севортян 1962).

2. Если учитывать только значения, наиболее близкие (семантически и генетически) к реципрокальному, то можно выделить три основных типа полисемии реципрокальных показателей: 1) рефлексивно-реципрокальная полисемия (ср. болгарск. (2) Te се гледат 'Они смотрят на себя/друг на друга'); 2) реципрокально-социативная полисемия (ср. бурятск. (3) асуу- 'спросить кого-л.' $\rightarrow$ асуу-лда-/асуу-лса- 'спросить друг друга'; (4) оро- 'войти' $\rightarrow$ оролда-/оро-лса- 'войти вместе'); 3) итеративно-реципрокальная полисемия, семантически связанная не только с реципрокальным, но и с социативным значением (ср. один из способов образования реципроков в китайском: (5) da-lai-da-qu (где $d a=$ 'бить') со значениями (а) 'бить друг друга', (б) 'драться несколько раз’; Liu 1999). В тюркских языках, как видно из примера (1), реализуется второй тип (традиционно именуемый взаимно-совместным залогом), равно как и в монгольских языках.

Каждый из этих трех типов полисемии может включать и другие значения, в той или иной мере характерные для каждого из них, а также общие значения (см. ниже значения соревнования, множественного числа и антикаузатива).

3. Занимая обширные территории, главным образом в Азии, тюркские языки входят в ареал, охватывающий большое число языков (не со всеми из которых они находятся в непосредственном контакте). Большинство из этих языков также имеют морфологические показатели реципрока: суффиксы (в монгольских, тунгусо-маньчжурских, чукотском и японском языках), префиксы (юкагирский, ительменский, нивхский, айнский) Из языков этого ареала только в кетском нет аффиксального реципрокального показателя. 
В тюркских языках существует пятичленная залоговая система (актив - пассив рефлексив - реципрок - каузатив); в других языках этого ареала морфологический рефлексив отсутствует (исключение - айнский и юкагирский).

Этот лингвистический ареал противостоит европейскому, в котором реципрокальное значение выражается в основном рефлексивным местоимением (ср. пример (2)), а морфологический каузатив отсутствует (исключение - балтийские языки, армянский и хинди). В известном смысле промежуточный ареал составляют угро-финские языки, где есть морфологический каузатив, а реципрокальное значение может выражаться рефлексивным суффиксом (ср. мансийск. (6) lowt-xat(u) 'мыться', titt-xat(u) 'кормить друг друга'; Е. Ромбандеева 1973) (исключение - эстонский и финский).

4. Между тюркскими языками наблюдаются заметные расхождения в плане полисемии реципрокального показателя не только в наборе, но и продуктивности перечисленных в разделе 1 четырех основных значений. В частности: а) реципрокальное значение, сохранившееся, видимо, в той или иной мере во всех тюркских языках, высокопродуктивно в якутском и непродуктивно в турецком, карачаево-балкарском; б) социативное значение высокопродуктивно в якутском языке, отсутстсвует в киргизском и ограничено образованием только (или преимущественно) от интранзитивов в татарском и карачаево-балкарском; в) к сказанному выше в разделе 1 об ассистивном значении добавлю, что в татарском языке (по данным Г. Зиннатуллиной 1969) этом значение даже несколько более продуктивно, чем реципрокальное. Реципрокальное и ассистивное значения отстоят друг от друга дальше, чем социативное, комитативное и ассистивное. Последние три значения в разных языках нередко выражаются одним показателем; ср., например, др.-греч. (7) fero 'нести' и sym-fero (а) 'нести что-л. вместе', (б) ‘с кем-л. вместе нести что-л.' и (в) 'помогать кому-л. нести что-л.'

Огрубляя картину, можно сказать, что в западной части тюркского ареала реципрокальное значение менее продуктивно, чем в остальной части ареала. В этой связи упомяну и отсутствие ассистивного значения в западном ареале.

5. Помимо названных четырех основных значений, охватывающих большие лексические группы глаголов, у реципрокального суффикса могут быть второстепенные значения, представленные ограниченным числом дериватов - от одного до нескольких десятков. Эти значения появлялись, видимо, в отдельных тюркских языках независимо от других (по логике расширения сочетаемости с различными основами). Отмечу следующие случаи.

а) Продуктивность значения соревнования в карачаево-балкарском языке. В других тюркских языках оно либо отсутствует (азербайджанский), либо охватывает узкое число дериватов (в пределах шести-двенадцати, например, в якутском), образуемых от транзитивов и интранзитивов, которые сами по себе ознчают действия, в которых соревнуются (например, 'бегать', ‘прыгать', ‘стрелять' и т.п.); в карачаево-балкарском же языке они свободно образуются от всех глаголов, называющих действия, по которым можно устроить соревнования, например, (8) сава-ш- 'соревноваться в дойке', арmbl-ш- 'соревноваться в чистке картошки'.

б) Значение множественности 3-го л. в киргизском языке (а также, м меньшей мере, в узбекском и казахском); ср.: (9) Биз am-ышu-mbl-к 'Мы стреляли друг в друга' (-mbl-= прош. вр., $-\boldsymbol{\kappa}=1$ л. мн.ч.; -ыш = рец. суф.) и (10) Aлар am-ыш-ты(-Ш = 3 л.; -ыши = рец. суф.), (б) ‘Они стреляли в кого-то’ (-ыш = 3 л.мн.ч.). Одновременное употребление суффикса -ыш в двух разных значениях грамматично, хотя и кажется необычным: (11) Aлар am-blu-blu-mbl 'Они стреляли друг в друга'.

Рассмотренные два значения, отсутствующие в ряде других тюркских языков, не случайны для реципрокального показателя, они встречаются и в других языках мира. Так, реципрокальный показатель в японском языке также продуктивен в значении соревнования. В болгарском языке имеется группа глаголов с приставкой над- и рефлексивно-реципрокальной клитикой се (см.(2)), выражающих соревнование; ср. (12) Те се надпиват 'Они соревнуются в выпивке' (К. Иванова 1973). Показатель реципрока в значении множественного числа встречается, например, в самоанском (Churchward 1951) и сахалинском айну (Chiri 1973). 
6. Существуют такие способы маркировки транзитивных локативных реципроков, т.е. реципроков, полученных в результате симметризации прямого и косвенного дополнений, референты которых соединяются: а) аффикс со значением соединения (ср. (13) Он приклеил $A$ $\kappa Б$-Он $\boldsymbol{c}$-клеил $A$ и Б); б) тот же аффикс, который используется для обычных реципроков (ср. кабардинский (14) гуэун 'кричать на кого-л.' $\rightarrow$ зэ-гуэун 'кричать друг на друга' и (15)

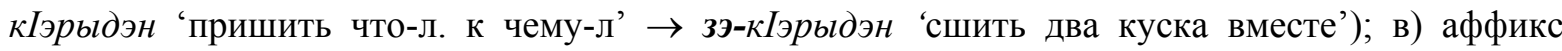
каузатива, присоединяемый к антикаузативу, образованного реципрокальным суффиксом. Именно этот способ характерен для некоторых тюркских яыков; ср. киргиз. (16) а. ула'присоединять что-л. к чему-л.', 'соединять концами' $\rightarrow$ б. ула-ш- 'присоединяться' $\rightarrow$ в. улаu-mыр- со значением 'связать вместе'. Конечный дериват близок по значению к базовому глаголу ула-. Речь здесь, видимо, идет о тенденции маркировать определенный тип глаголов. Рассмотрим последний случай подробнее.

a) Антикаузативное значение. Дериваты с антикаузативным значением образуются в тюркских языках главным образом от трехместных транзитивов, которые могут функционировать как лексические реципроки (с симметричными объектными аргументами; см. (16)). Аналогичное значение встречается и в других языках у реципрокальных показателей. Особенно продуктивно это значение у рефлексивно-реципрокальных показателей, антикаузативные дериваты с которыми не имеют таких лексических ограничений; ср. (17) сломать $\rightarrow$ сломаться-ся. Так, в русском языке антикаузативная функция является одной из основных у рефлексивно-реципрокального показателя (около 1400 дериватов). В тюркских языках антикаузативы такого рода отразуются с помощью и других залоговых показателей (на $-л$ и на $-\boldsymbol{\mu}$ ), и они могут быть синонимичны с дериватами с реципрокальным показателем; ср. якутск. (18) силимнээ- 'склеить что-л. с чем-л.' $\rightarrow$ силимнеc- 'склеиться вместе' и силимне-н- 'склеиться вместе' (Л. Харитонов 1963). Антикаузативы, образуемые реципрокальным показателем, отмечены и в нетюркских языках: зулу (Damman 1954), муна (van der Berg 1989), монгольском (Г. Санжеев 1963) и др.

б) Каузативы от антикаузативов. Тенденция, проиллюстрированная в (16), проявляется иногда и в тех случаях, когда в языке существуют локативные реципроки, отмеченные только реципрокальным показателем (т.е. типа, показанного в (14) и (15)); ср. киргизск. (19) а. как'стукнуть' $\rightarrow$ б. каг-ыш- (i) 'ударять один предмет о другой', (ii) 'сталкиваться' $\rightarrow$ в. каг-ышmыр- 'ударять один предмет о другой’. К двум синонимичным транзитивам (см. (19б) и (19в)) можно добавить еще один (20г), опять же с реципрокально-каузативным показателем: (20) а. как- 'стукнуть' $\rightarrow$ б. каг-ылл- 'стукнуться' $\rightarrow$ в. каz-blл-blu- 'стукнуться друг о друга' $\rightarrow$ г. кагbыл-ыш-mыр- 'стукнуть один предмет о другой'.

в) Реципрокально-каузативные аффиксы. Сочетание реципрокального и каузативного суффикса может переосмысливаться и выступать как единый показатель. Этот сложный реципрокально-каузативный суффикс -штыр- может маркировать трехместные транзитивы, даже минуя антикаузативный дериват от базового непроизводного глагола, поскольку такого среднего звена либо вообще нет, либо этот дериват семантически не соотносится с последним в цепочке реципрокально-каузативным дериватом; ср. киргизск. (21) а.байла- 'привязать чтол. к чему-л.' $\rightarrow$ б. байла-штыр- 'связать вместе (например, лошадей)'; форма байла-шсуществует, но семантически не соотносится с последней, поскольку имеет значения ‘привязывать что-л. вместе' или 'помогать привязывать'.

Формы, аналогичные байла-штыр-, встречаются и в других языках, опять же для трехместных транзитивов, обозначающих соединение объектов; ср. японск. (22) а. xar-u 'приклеить что-л. к чему-л.' $\rightarrow$ б. xar-aw-ase-ru 'склеить что-л. вместе' $(-\boldsymbol{a} /-\boldsymbol{a w}$ - = реципрокальный суффикс, -ase- = каузативный суффикс). У исходного глагола реципрокальная форма типа *xari-a-u отсутствует (М. Himeno 1982). Глаголов с суффиксом aw-ase- насчитывается более пятидесяти.

7. Тюркские конструкции с реципрокальным аффиксом представляют собой типологически интересный материал в плане как внутритюркского, так и общетипологического сопоставления. 


\section{ЛИТЕРАТУРА}

АПАЖЕВ, М.Л. и др. 1957. Кабардинско-русский словарь. Москва: Гос. изд-во иностр. и национальных словарей.

ГАлКИН, И.С. (гл. ред.). 1966. Русско-марийский словарь. Москва: Изд-во Советская энциклопедия.

ДвОРЕцКИЙ, И. Х. 1958. Древнегреческо-русский словарь. Москва: Изд-во Русский язык.

ЗИННАТУЛЛИНА, Г. 1969. Залоги глагола в современном татарском литературном языке. Казань: Татарское книжное изд-во.

ИВАНОВА, К. 1987. Някои случаи на взаимодействие между категориално различни явления в областта глагола. Славистичен сборник. София, 171-179.

РОМБАНДЕЕВА, Е.И. 1973. Мансийский (вогульский) язык. Москва: Наука.

САНЖЕЕВ, Г. Д. 1963. Сравнительная грамматика монгольских языков. Москва: Изд-во восточной литературы.

СЕВорТян, Э. В. 1962. Аффиксы глаголообразования в азербайджанском языке. Опыт сравнительного исследования. Москва: Изд-во восточной литературы.

ТЕПЛЯШИНА, Т. 1966. Удмуртский язык. В кн.: В.И. Лыткин и др. (ред.). Языки народов СССР. Том III. Финно-угорские и самодийские языки. Москва: Наука, 261-281.

ХАРИТОНОВ, Л.Н. 1963. Залоговые формы глагола в якутском языке. Москва, Ленинград: Издво Академии Наук СССР.

ЧЕРЕМИСОВ, К. М. 1973. Бурятско-русский словарь. Москва: Изд-во Советская энциклопедия.

ЮДАХИН, К. К. 1965. Киргизско-русский словарь. Москва: Изд-во Советская энциклопедия.

CHIRI, M. 1973. Studies in Ainu Grammar - with Emphasis on the Sakhalin dialect. In Chiri Mashiho Chosakushuu, vol. 4. Tokyo: Heibonsya (на японском языке).

Churchward, S. 1951. A Samoan Grammar. Melbourne: Spectator Publishing Co. Pty Ltd.

DAMMAN, E. 1954. Reziprok und Assoziative in Bantusprachen. Zeitschrift der Deutschen morgenländischen Gesellschaft. Bd. 104, Heft 1, 163-174.

HIMENO, M. 1982. Auxiliary verbs denoting symmetry relations (about au and awaseru). Nihongakoo ronshuи, 9, 17-52 (на японском языке).

KUUlAR, K. Reciprocals, comitatives and assistives in Tuvan. In V. P. Nedjalkov (ed.), Typology of Reciprocal Constructions (to appear).

LIU, M. 1999. Reciprocal marking with deictic verbs come and go in Mandarin. In Z. Frajzyngier, T.S. Curl (eds.), Amsterdam, Philadelphia: John Benjamins.

NedjalKov, V. P. 2002. Karachay-Balkar reciprocals. Turkic Languages 6, 19-80.

NedJALKOV, V. P. 2003. Yakut reciprocals. Turkic Languages 7, 1-77.

NeDJALKov, V. P. Reciprocals, assistives and plural in Kirghiz. In V. P. Nedjalkov (ed.), Typology of Reciprocal Constructions (to appear).

VAN DEN BERG, R. 1989. A Grammar of the Muna Language. Dordrecht: Foris Publication. 
1) в английский вариант:

а) стр. 1, 8-ая строка снизу: Turkmenian вместо Turkmen;

б) стр. 2, 6-ая строка сверху: Cheremisov вместо Cheremisin.

в) стр. 2, 8-ая строка снизу: после Tepljashina добавить 1966.

\section{REFERENCES}

APAZHEV, M. ET AL. 1957. Kabardinsko-russkij slovar' [Kabardian-Russian dictionary]. Moskva: Gos. izd-vo inostr. i nacional'nyx slovarej.

Cheremisov, K. 1973. Burjatsko-russkij slovar' [Buryat-Russian dictionary]. Moskva: Izd-vo Sovetskaja enciklopedija.

CHIRI, M. 1973. Studies in Ainu Grammar - with Emphasis on the Sakhalin dialect. In Chiri Mashiho Chosakushuu, vol. 4. Tokyo: Heibonsya (in Japanese).

ChurchWARD, S. 1951. A Samoan Grammar. Melbourne: Spectator Publishing Co. Pty Ltd. 
DAMMAN, E. 1954. Reziprok und Assoziative in Bantusprachen. Zeitschrift der Deutschen morgenländischen Gesellschaft. Bd. 104, Heft 1, 163-174.

DVORECKIJ, I. X. 1958. Drevnegrechesko-russkij slovar' [Ancient Greek-Russian dictionary]. Moskva: Izd-vo Russkij jazyk.

GALKIN, I. (ed.). 1966. Russko-marijskij slovar' [Russian-Mari dictionary]. Moskva: Izd-vo Sovetskaja enciklopedija.

HIMENO, M. 1982. Auxiliary verbs denoting symmetry relations (about au and awaseru). Nihongakoo ronshuu, 9, 17-52 (in Japanese).

IVANOVA, K. 1987. Някои случаи на взаимодействие между категориално различни явления в областта глагола. Славистичен сборник. София, 171-179.

KUUlaR, K. Reciprocals, comitatives and assistives in Tuvan. In V. P. Nedjalkov (ed.), Typology of Reciprocal Constructions (to appear).

LIU, M. 1999. Reciprocal marking with deictic verbs come and go in Mandarin. In Z. Frajzyngier, and T. S. Curl (eds.), Amsterdam, Philadelphia: John Benjamins.

NeDJALKOV, V. P. 2002. Karachay-Balkar reciprocals. Turkic Languages 6, 19-80.

NEDJALKOV, V. P. 2003. Yakut reciprocals. Turkic Languages 7, 1-77.

NeDJALKOV, V. P. Reciprocals, assistives and plural in Kirghiz. In V. P. Nedjalkov (ed.), Typology of Reciprocal Constructions (to appear).

RoMBANDEEVA, E. 1973. Mansijskij (vogul'skij) jazyk [Mansi (Vogul) language]. Moskva: Nauka.

SANZHEEV, G. 1963. Sravnitel'naja grammatika mongol'skix jazykov [A comparative grammar of Mongolian languages]. Moskva: Izd-vo vostochnoj literatury.

SEVORTJAN, E. 1962. Affiksy glagoloobrazovanija v azerbajdzhanskom jazyke [Affixes of verbal derivation in Azerbaijani. An attempt of comparative analysis]. Moskva: Izd-vo vostochnoj literatury.

TEPLJASHINA, T. 1966. Udmurtskij jazyk [The Udmurt language]. In V. I. Lytkin et al. (eds.), Jazyki narodov SSSR [Languages of the peoples of the USSR]. Tom III. Finno-ugorskie $i$ samoedskie jazyki [Finno-Ugric and Samoyedic languages]. Moskva: Nauka, 261-281.

VAN DEN BERG, R. 1989. A Grammar of the Muna Language. Dordrecht: Foris Publication.

XARITONOV, L. 1963. Zalogovye formy glagola $v$ jakutskom jazyke [Voice forms of the verb in Yakut]. Moskva, Leningrad: Izd-vo Akademii Nauk SSSR.

YUDAKHIN, K. 1965. Kirgizsko-russkij slovar' [Kirghiz-Russian dictionary]. Moskva: Izd-vo Sovetskaja enciklopedija.

ZINNATUllinA, G.. 1969. Zalogi glagola v sovremennom tatarskom literaturnom jazyke [Verbal voices in present-day Standard Tatar]. Kazan': Tatarskoe knizhnoe izd-vo. 


\title{
ARGUMENT STRUCTURE OR EVENT STRUCTURE? \\ - THE CASE OF JAPANESE AND KOREAN CAUSATIVES -
}

\author{
MASAYOSHI SHIBATANI \\ Rice University in Texas
}

Since the time of the generative semantics controversy in the 70's, studies of Japanese causative constructions have yielded particularly interesting results concerning the argument structure and grammatical relations of morphological causative constructions. In particular, the scope of adverbial modification and the reflexive construal phenomenon have presented compelling evidence that productive morphological causative constructions involve a complex embedding underlying structure with two distinct subjects despite their simplex surface structure with a single subject nominal. The evidence from reflexive construal has been especially convincing for the bi-clausal analysis of morphological causatives, for it unambiguously refers to a syntactic fact, namely, the relationship between the grammatical relation of subject and the reflexive anaphor.

This presentation attempts a critical reassessment of the past evidence in light of a comparative study of causative constructions in Japanese and Korean, which together cover the entire spectrum of causative type, ranging from lexical to periphrastic constructions with morphological causatives of varying degrees of productivity in between. The results indicate that there is no uniform correspondence between form and syntactic fact. Rather, the relevant syntactic evidence responds to different kinds of event structure more abstract than syntactic argument structure. Especially significant is the situation where a factor not representable in syntactic terms holds a crucial key in the interpretation of the reflexive anaphor. A new reflexive-construal rule is offered that obviates the need to posit bi-clausal underlying syntactic structures for morphological causatives. 


\title{
THREE TAKES ON GRAMMATICAL RELATIONS: A VIEW FROM THE LANGUAGES OF EUROPE AND NORTH AND CENTRAL ASIA.
}

\author{
ANNA SIEWIERSKA, Lancaster University \\ DIK BAKKER, University of Amsterdam
}

The view that GRs are not primitive notions but rather are identifiable in terms of restricted neutralization of semantic and pragmatic relations lies at the heart of the typologies of GRs developed by Kibrik (1997, 2001), Dik (1997 and earlier work) and Van Valin \& La Polla (1997 and earlier work). Despite their common point of departure the three typologies differ substantially in regard to the level at which GRs are posited (the language vs. the constuction), the range of GRs recognised (potentially three by Kibrik, two by Dik and one by Van Valin \& La Polla) and the nature of the neutralization taken to define the GRs. In this talk we will compare the above three approaches to GRs focusing first on the role of voice alternations in determining the presence of GRs in a language and then on the role of morpho-syntactic alignment in determining the sub-types of GRs posited. The differences between the three approaches will be illustrated on the basis of the GRs that each identitifes in a range of languages from the Indo-European, Uralic, Tungusic, Mongolic and Turkic families. The talk will conclude with a consideration of the descriptive and typological value of the three classifications of GRs under discussion.

\section{REFERENCES}

Dik, SimOn C. 1997. The Theory of Functional Grammar. Part 1: The Structure of the Clause. Kees Hengeveld (ed.). Berlin: Mouton der Gruyter.

KIBRIK, A.E. (1997). Beyond subject and object: toward a comprehensive relational typology. Linguistic Typology 1-3: 279-346.

KIBRIK, A.E. 2001. Subject-oriented vs. Subjectless languages. In Martin Haspelmath, Ekkehard König, Wulf Oesterreicher, and Wolfgang Raible 9eds.), Language Typology and Language Universals. An International Handbook. vol 2 Berlin: Walter de Gruyter, 1413-1423.

VAN VAlin, R. D. \& R. J. LAPOLLA. 1997. Syntax. Cambridge: Cambridge University Press. 


\title{
DEFINING TRANSITIVITY AND INTRANSITIVITY: SPLIT-INTRANSITIVE LANGUAGES AND THE UNACCUSATIVE HYPOTHESIS
}

\author{
ASIER ALCÁZAR \\ University of Southern California, Los Angeles
}

\section{Proposals}

0.1 Basque is not an ergative language; it is split-intransitive.

* Against the standard typological claim (contra Comrie 1981, Dixon 1994, Primus 1999)

0.2 Unergative verbs are not always intransitive (they can be transitive: e.g. Basque).

* Against the claim in the Unaccusative Hypothesis (contra Perlmutter 1978, Burzio 1986)

0.3 Split-intransitivity signals that unergatives are transitive.

* Novel claim: split-intransitivity has been otherwise considered an anomalous pattern.

1. INTRODUCTION: INTRANSITIVE VERBS WITH TRANSITIVE LOOKS (I.E. 1A). Basque is often presented as a splendid example of ergativity (Comrie 1981, Dixon 1994, Primus 1999 among many). Traditionally, ergative languages differ from accusative languages in the verbal argument they mark. Ergative languages mark the subject of transitives (compare the girl in 2 with 1b) and accusative languages mark the object of transitives (e.g. Latin/Romance; see the feminine singular pronoun in 4). However, the axioms in the typological classification of languages would by definition declare Basque to be of type split-intransitive (e.g. like Guarani, Gregorez and Suarez 1967 cfr. Primus 1999; or Slave, Rice 1991). For Basque has a class of intransitive verbs (1a) whose argument is marked exactly as the subject of transitives (2).

Basque intransitives:
(1)a. Neskatil-ak dei-tu du girl-Erg.Sg call-Per have.3Sg_3Sg 'The girl called'
b. Neskatil-a ailega-tu da girl-Abs.Sg arrive-Per be.3Sg 'The girl arrived'

Basque transitives:

(2) Neskatil-ak izozki-a amai-tu du girl-Erg.Sg ice-cream-Abs.Sg finish-Per have.3Sg_3Sg

'The girl finished her ice-cream'

Spanish intransitives:
(3)a. Ella llam-s she.Nom call-3Sg.Past
'She called'
b. Ella lleg-s she.Nom arrive-3Sg.Past 'She arrived'

Spanish transitives:
(4) Ella la acab-s (la nieve) she.Nom it.Acc.Fem.Sg finish-3Sg.Past (the.Fem.Sg ice-cream-Fem.Sg) 'She finished it' (where it $=$ her ice-cream)

2. THE CONSEQUENCES OF (1A) FOR THE UNACCUSATIVE HYPOTHESIS AND TYPOLOGICAL STUDIES. The class of intransitives exemplified by (1a) is identified with unergative verbs (see Laka 1993, 1995). Basque unergatives for the most part overlap with the unergatives recognized for IndoEuropean (Burzio 1986, Sorace 2000). Thus, some examples of intransitive verbs like (1a) in Basque include, but are not limited to, verbs like blow, cough, dance, dream, run, and work. Basque unergatives do not parallel transitives only in ergative case marking on their argument. In addition, unergatives also require auxiliary have (unaccusatives be) and they must show subject and object agreement in the auxiliary. In fact, over 50 commonly used unergatives (Zubiri 2000) (may) surface as light verbs of the form [Noun + Do] (see 5). The noun argument cannot bear absolutive case (Ortiz de Urbina 1989) as it would in a transitive (2) or intransitive (1b) sentence.

$$
\begin{array}{lrll}
\text { Neskatil-ak dei } & \text { egi-n } & \text { du } \\
\text { Girl-Erg.Sg call } & \text { do-Per } & \text { have.3Sg_3sg } \\
\text { 'The girl called' } &
\end{array}
$$


2.1. THE UnACCUSATIVE Hypothesis Claims that UNERgatives ARE INTRANSITIVE. The unergative-unaccusative distinction arises from Perlmutter's Unaccusative Hypothesis (1978, henceforth UH). For Perlmutter the traditional term intransitive encompasses a mixed group of nontransitive verbs (like 1a, 1b) that select a single expressed argument (e.g. the girl). Perlmutter proposes that the argument of intransitives is originally a canonical subject (e.g. dance, run) or an internal argument (e.g. arrive, break), and coins the terms unergative and unaccusative, respectively (not to be confused with ergativity and accusativity). In Italian Syntax, Burzio (1986) later formalizes the idea that the internal argument of unaccusative verbs becomes a subject marked nominative due to the inability of the verb to case-mark its argument. Italian provided much empirical support for the UH. Intransitives split in auxiliary choice, participial agreement, and ne-cliticization, among other morphosyntactic tests. Basque parallels and enhances these tests showing at the same time that unergatives are transitive.

2.2. TYPOLOGICAL STUDIES TREAT SPLIT-INTRANSITIVITY AS AN ANOMALOUS PATTERN. The typological classification assumes that languages mark an argument only if there is more than one argument (the transitive case). Thus, intransitives are unmarked in accusative and ergative languages. Split-intransitivity challenges this classification for a class of intransitives is marked like transitives. This anomaly can be ruled into the model by assuming that in split-intransitive languages unergatives are transitive verbs. If unergatives have a latent object, like examples (1a) and (5) from Basque suggest, then one of the two arguments needs to be marked.

$\begin{array}{llll} & \text { Mark Subject } & & \text { Mark Object } \\ \text { Intransitive } & \text { Unergatives } & \text { Ergative } & \text { Accusative } \\ \text { Transitive } & \text { Unergatives } & \text { Split-intransitive } & \text { Split-intransitive 3. }\end{array}$

(6) TABLE 1: Ergativity, Accusativity and Split-intransitivity explained away.

3. CONCLUSION. Basque unergatives (1a) call for a new classification of Basque in the typological literature. The long standing claim that unergatives are intransitive does no longer hold. Splitintransitivity follows from the typological axioms assuming that unergatives are transitive in these languages.

\section{SELECTED REFERENCES}

BuRZIO, L. 1986. Italian Syntax. A Government-Binding Approach. Dordrecht: Reidel.

COMRIE, B. 1981. Language Universals and Linguistic Typology. Chicago: The University of Chicago Press.

DiXON, R.M.W. 1994. Ergativity. Cambridge: Cambridge University Press.

LAKA, I. 1993. Unergatives that Assign Ergative Case, Unaccusatives that Assign Accusative. In J.D. Bobaljik et al (eds.), Papers on Case and Agreement I. MITWPL 18, 149-72. Cambridge.

LAKA, I. 1995. Thetablind case: Burzio's generalization and its image in the mirror. In E. Reuland (ed.), Arguments and Case: Explaining Burzio's generalization, 103-129. Amsterdam: John Benjamins.

SORACE, A. 2000. Gradients in Auxiliary Selection with Intransitive Verbs. Language, 76: 4.

ORTIZ DE URBINA, J. 1989. Parameters in the Grammar of Basque. Dordrecht: Foris.

PerlmutTer, D.M. 1978. Impersonal Passives and the Unaccusative Hypothesis. In Proceedings of the Fourth Annual Meeting of the Berkeley Linguistics Society, 157-189. Berkeley Linguistics Society.

Primus, B. 1999. Cases and Thematic Roles: Ergative, Accusative, Active. Tübingen: Max Niemeyer Verlag.

RICE, K. 1991. Intransitives in Slave (Northern Athapaskan): Arguments for Unaccusatives. International Journal of American Linguistics. Chicago: The University of Chicago.

ZUBIRI, I. 2000. Euskal Gramatika Osoa. Bilbao: Didaktiker. 


\title{
THE STRUCTURE OF VERB PHRASE IN PERSIAN WITH PARTICULAR REFERENCE TO VP INTERNAL SUBJECT HYPOTHESIS
}

\author{
ALI ALIZADEH \\ Islamic Azad University, English Department, \\ Torbat Heidariyeh Branch, Torbat Heidariyeh, Iran
}

This paper investigates the position of subject in Persian (a language spoken in Iran) with particular reference to the VP Internal Subject Hypothesis (ISH). The study is carried out within the framework of Government and Binding as developed in Chomsky $(1981,1986 \mathrm{~b})$ and the subsequent works. In the traditional form of the X-bar model, subject is considered to be generated in Spec. of IP where it is assigned nominative case by the tense and agreement features of INFL. This research deals with a proposal which has recently been gaining ground in the literature through a number of studies by Fukui and Speas (1986), Kitagawa (1986), Kuroda (1988), Sportiche (1988) and Koopman and Sportiche (1991).

In their analysis, it is argued that subject is base generated in Spec. of VP and then moves to Spec. of IP at S-structure to receive case. This movement as an instance of an NP-movement is case driven. The present study has analysed Persian data in the light of this hypothesis. The analysis shows that ISH does not receive support from Persian data. It seems that movement of subject is an instance of topicalisation in Persian from Spec. of IP into Spec. of Top P, a position higher than IP according to Split CP Hypothesis. It shown that A'-movement, not a case driven A-movement is involved. The structure of the sentences in which the movement of subject and wh-movement take place simultaneously shows that the Spec. of Top P is the only potential landing site of subject after movement and adjunction to IP or Spec. of CP cannot be considered as its landing site. The position of PRO in Persian embedded finite clauses shows that the PRO theorem cannot be maintained by generating it in Spec. of VP. I have also proposed as a result that the base generated position of subject at the D-structure level and having a derived or non derived subject at S-structure is a language parameter. Persian is a language whose subject is non derived and is base generated in the Spec. of IP at D-structure level. In this study, I also show that the direct object which is characterized by the feature [+ Specific] is in the Spec. of VP at S-structure level.

\section{REFERENCES}

ABNEY, S. (1994) The English Noun Phrases in Its Sentencial aspects. Unpublished diss, Cambridge, Mass: MIT.

Chomsky, N. 1965a. Aspects of the Theory of Syntax. MIT Press: Cambridge, Mass.

ChOMSKY, N. 1981a. Lectures on Government and Binding. Dortrecht: Foris.

GHOMESHI, JiLA. 1996. Projection and Inflection: A Study of Persian Phrase Structure, Ph.D. diss, University of Toronto.

GHOMESHI, JiLA. 1997b. Topics in Persian VPs. Lingua 102, 133-167

HAEgeman, L. 1994. Introduction to Government and Binding. Cambridge: Blackwell Publishers Ltd.

Hajati, AbDOl-Khalil. 1977. Ke Construction in Persian, Descriptive and Theoretical Aspects, unpublished PhD. Dissertation, University of Illinois, Urbana.

JACKENDOFF, R S. 1977. X bar Syntax: A Study of Phrase Structure: Cambridge, Mass: MIT Press.

KARIMI, SIMIN. 1989. Aspects of Persian Syntax; Specificity and the Theory of Grammar, unpublished Ph.D. Dissertation, University of Washington.

KARIMI, SIMIN. 1999. A note on parasitic gaps and specificity. Linguistic Inquiry 30, 704-713

KitagawA, Y. 1986. Subject in Japanese and English, Ph.D. diss. University of Massachusetts, Amherst.

KoIZUMI, M. 1995. Phrase Structure in Minimalist Syntax, Ph.D. diss, MIT.

KOOPMAN, H., and D. SPORTICHE. 1991. The position of subjects. Lingua 85, 211-258

KURODA, Y. 1986. Whether we agree or not, Ms, UCSD.

POLLOCK, J. Y. 1986. Verb movement, UG and the structure of IP. Linguistic Inquiry 20, 364-426 
RADFORD, A. 1997. Syntax, A Minimalist Introduction, Cambridge: Cambridge University Press.

SPEAS, M. and N. FUKUI. 1986. Specifiers and projection. MIT working papers 8, Department of Linguistics and Philosophy. Cambridge, Mass: MIT.

SPORTICHE, D. 1988a. A theory of floating quantifiers and its corollaries for constituent structure. Linguistic Inquiry 19, 425-49. 


\title{
RUSSIAN STATE UNIVERSITY FOR HUMANITIES, MOSCOW TWO-TERM CASE SYSTEMS IN THE INDO-IRANIAN LANGUAGES: A TYPOLOGICAL PERSPECTIVE
}

\author{
PETER M. ARKADIEV \\ Russian State University for Humanities, Moscow
}

The Indo-Iranian languages which occupy a large area in Southern and Central Asia reveal a great diversity of linguistic structures, as well as a certain degree of areal consistency. In the domain of case one of the most prominent features is the presence of two-term systems. Such systems are of particular interest, since they reveal some basic patterns of how language can structure the core grammatical relations, and those semantic relations which are associated with them. In Indo-Iranian there are two-term case systems of quite different morphological and functional types. In this paper I will focus on the functional domain, although some remarks about the formal properties are necessary as well.

Two-term case systems usually arise through reduction of more elaborate systems (Lehmann 1995 [1982]: 121); that is the most frequent case in Indo-Iranian, although newly developed two-term case systems can be found, too (cf. Tati). Old case systems usually have several declension types, often both cases are marked, their markers are either cumulated with number or sensitive to it; the overall degree of fusion of the case marker with the stem is relatively high. On the contrary, in the new case systems one of the terms is formally unmarked, and the Oblique case marker is either a clitic or a loosely attached affix. However, the distinction is quite often blurred through multiple restructurings of the nominal paradigms which occurred in the history of some languages (cf. Khovar, Yagnob).

Turning to the semantic and functional content of two-term case systems in the Indo-Iranian languages, it is necessary to emphasize the great degree of variation in respect both of the functional domains covered by each case and the organization of the core and also a number of recurrent common features.

Although most of the languages exhibit a split-ergative system, there is a minority with a purely accusative system, comprising both some of the Dardic languages in the eastern (Prasun, Khovar) and some of the Iranian languages in the western part of the area (Tati). However, no rigid ergative system similar to that of the Daghestanian languages is attested in Indo-Iranian. Such a situation is due to the origin of the ergative construction in these languages which stems from the ancient passive construction (cf. Estival and Myhill 1988) and at least in some languages (e. g. Urdu) is an innovation of a relatively recent origin. Another common peculiarity of these languages is the so-called differential object marking (Bossong 1985), when the O relation is marked either by the Direct case (when the $\mathrm{O}$ is inanimate and/or indefinite) and by the Oblique case or a prepositional phrase (when the $\mathrm{O}$ is animate and/or definite).

There is also a tendency to align particular peripheral relations, such as Possessive, Locative, Goal, Temporal, Purpose with the core relations, thus marking them with the 'bare' Direct or Oblique case without any adposition. These relations are marked either by one of the cases or are distributed among them, which constitutes one of the main parameters of variation.

Another variable feature is the co-occurrence of the cases with adpositions. In some languages (Kati, Shina, Yagnob) both cases can be governed by certain adpositions, in other (Vaigali, Pashto) only the Oblique case can co-occur with them; there is no language, however, where adpositions would exclusively require the Direct case. It is also interesting to note that Indian languages (Hindi, Nepali) tend not to allow the 'bare' Oblique case, the latter always followed by a postposition.

Two-term case systems in the Indo-Aryan region may serve as an excellent polygon for the cross-language study of that phenomenon. It should be kept in mind that some of the features common to these languages may be found elsewhere. 
REFERENCES

Bossong, G. 1985. Empirische Universalienforschung: differentiale Objektmarkierung in neuiranischen Sprachen. Tübingen: Narr.

ESTIVAL, D., and J. MYHILL. 1988. Formal and functional aspects of the development from passive to ergative systems. In M. Shibatani (ed.), Passive and Voice, 441-491. Amsterdam, Philadelphia: John Benjamins.

LEHMANN, Christian. 1995 [1982]. Thoughts on Grammaticalization. München \& Newcastle: LINCOM Europa. 


\title{
GRAMMATICAL RELATIONS IN A TYPOLOGY OF AGREEMENT SYSTEMS
}

\author{
GREVILLE G. CORBETT \\ Surrey Morphology Group \\ Linguistic, Cultural and International Studies, School of Arts \\ University of Surrey, Guildford
}

1. INTRODUCTION. We ask how useful grammatical relations are for constructing a typology of agreement systems. We first sketch the development of work on grammatical relations, and earlier suggestions about their relevance for agreement. Then we move to a typology, taking as canonical those instances that can be described in terms of grammatical relations, and examining the types of construction which require access to additional information. Examples are taken from various languages, but especially from Russian which, though it appears to have a rather 'standard' agreement system, poses considerable problems for an account of agreement based on grammatical relations, as demonstrated by data from corpus-based studies.

2. THE RISE OF GRAMMATICAL RELATIONS. The notion 'grammatical relation' is well established (see Blake 1994: 48-93, Palmer 1994, Givón 2001: 173-232, Kibrik 2003: 109). It has a continuous tradition in European linguistics, while the attempt in transformational grammar to treat sentence structure in terms of dominance and linear order led to a reaction, particularly in America, in which the need for grammatical relations was carefully justified, rather than being assumed. This is most evident in Relational Grammar, where grammatical relations are given central status (see Perlmutter 1983a, Perlmutter and Rosen 1984, Postal and Joseph 1990, Blake 1990). A parallel reaction is found in the typology of Keenan and Comrie (1977). ${ }^{1}$ 156):

Grammatical relations are treated hierarchically, as in the Relational Hierarchy (Johnson 1977:

subject $>$ direct object $>$ indirect object $>$ other object

The Accessibility Hierarchy of Keenan and Comrie (1977: 66) further divides 'other objects'. In subsequent years, grammatical relations have been embedded in different theories, with somewhat different interpretations. They have a core role in Lexical Functional Grammar, as 'grammatical functions' (Bresnan 2001: 44-60).

3. EARLY IDEAS ON GRAMMATICAL RELATIONS AND AGREEMENT. The Relational Hierarchy was considered directly relevant to agreement. Thus Moravcsik (1978: 364) claimed that if a language shows agreement, then there will be cases of agreement with the intransitive subject; only if there is such agreement will there be agreement with the direct object, and agreement of this type is a precondition for agreement with the indirect object. This is a typological claim at the level of possible languages. A more restrictive claim was made by Johnson (1977: 157):

THE AGREEMENT LAW: Only terms can trigger verbal agreement.

Where 'term' covers the first three items on the hierarchy.

4. PROBLEMS With GRAMMATICAL RELATIONS. If Johnson's claim could be maintained, we would indeed have a highly restricted theory of agreement, and a fine basis for a typology. ${ }^{2}$ However, Ais-

\footnotetext{
${ }^{1}$ Note, however, that the argument is not only in one direction. After detailed discussion of Spanish psychological predicates Vogel and Villada (1999) conclude that 'subject' is not a particularly helpful notion.

${ }^{2}$ It should be pointed out that much of the early discussion dealt with verbal affixes whose status has since been debated as to whether they are agreement markers or pronominal affixes (see Corbett 2003 for discussion).
} 
sen in various papers, and definitively in (1990), pointed out the problem of 'brother-in-law' agreement, as in There are cows in next door's garden. Such constructions have a dummy element (like English there) in the term position, while its 'brother-in-law' acts as the agreement controller. Perlmutter (1983b) permits 'silent' dummies, which allows for analyses in which apparent terms are analysed as brothers-in-law to zeroes.

There is a second type of non-term which can control agreement, namely predicate nominals, in instances of 'back' agreement. Examples will be given, of which the most convincing are from Czech (Vanek 1970, Corbett 1998).

Just as there are instances where a noun phrase which would be predicted not to be the agreement controller according to an account based on grammatical relations actually controls agreement, so also we find the converse, where the predicted controller fails to control agreement. Thus in Russian possessive constructions, the possessor phrase is subject-like in that it controls reflexivization, but agreement is not with this noun phrase.

5. A tYPOLOGY OF AGREEMENT USING GRAMMATICAL RELATIONS. Since our main focus is agreement, we shall ask how far grammatical relations allow us to determine how agreement operates in different languages. Suppose we can establish the grammatical relations in a particular construction according to other criteria (for instance according to the criteria of Keenan $1976{ }^{3}$, that is, controlling reflexives, being the target for promotion, being the missing argument for imperatives, and so on, discussed in Comrie 1989: 104-123). Can we then straightforwardly determine how agreement will operate?

We have seen already that our typology must include instances where the controller is outside the candidate noun phrases provided by an approach based on grammatical relations. But our typology needs to go beyond grammatical relations for a second, more subtle, reason. Even when grammatical relations are sufficient to determine the controller, they may still be insufficient for determining the feature values involved in agreement. When we have agreement options (which are prevalent in Russian, as for instance with quantified expressions), ${ }^{4}$ the feature value assigned can be influenced by considerations outside the scope of grammatical relations. To extend the typology, a suggestion of Polinsky proves useful. Polinsky (1995: 360) gives the following mappings for the 'regular active transitive construction'

$\begin{array}{llc}\begin{array}{l}\text { thematic roles } \\ \text { grammatical relations }\end{array} & \begin{array}{l}\text { Agent } \\ \text { subject }\end{array} & \begin{array}{c}\text { Theme } \\ \text { direct object } \\ \text { fommunicative functions }\end{array} \\ \text { topic } & \text { focus }\end{array}$

'the clause is viewed as a linguistic sign having three distinct levels of representation, namely: the meaning of the clause, represented by thematic roles and verbal semantics, and the form of the clause represented by grammatical relations, on the one hand, and by communicative functions, on the other.' (1995: 360)

Perhaps surprisingly, a typology of agreement requires access to information of all three types. If we consider agreement with quantified noun phrases in subject position in Russian, the feature value for number depends in part on the semantics of the clause. Corpus-based studies have shown that the more agent-like is the subject (as evidenced by the semantic type of the predicate), the more likely is plural agreement (Corbett 1983, Robblee 1993). Similarly we need access to communicative function, in that the more topic-like the subject (as reflected in word order) the more likely is plural agreement (Corbett 1998). We shall provide examples of the different types, showing the role of these two sorts of information in addition to that provided by grammatical relations (as in, for instance, Nocentini 1999 and Nikolaeva 2001), in order to fill out the proposed typology.

\footnotetext{
${ }^{3}$ We must recognise that criteria can differ substantially from researcher to researcher, and so comparison of different claims is often difficult. For careful discussion of dative subjects see Moore and Perlmutter (2000).

${ }^{4}$ A relevant article, fully in the Relational Grammar tradition, arguing that quantified noun phrases in Polish can indeed be subjects, even though the verb does not agree, is Dziwirek (1990).
} 
6. THE ROLE OF CASE. We might expect that if we appeal to grammatical relations we shall not also need to refer to case. Indeed the Relational Grammar literature stressed the importance of instances where the controller was of the 'right' grammatical relation but the 'wrong' case (quirky case) and still controlled agreement. These were discussed in detail with regard to Georgian, notably by Harris (1981); for later analyses giving a greater role to morphology see Anderson (1984) and Kathman (1995). However, there are clear instances demonstrating the need to refer to case as well as to grammatical relations for specifying agreement. These are of two types.

First, in terms of the controller, we find instances, as in Russian, where a noun phrase in the right grammatical relation (subject) but not in the right case (nominative) cannot control agreement (as in the possessive constructions mentioned above). Moreover, the non-subject noun phrase which is in the nominative does control agreement. For other comparable examples see Bickel and Yadava (2000) and Butt (2001); and for discussion of Inari Sami see Toivonen (2003). Note the regularity that when the noun phrase in the 'right' grammatical relation has its controlling potential usurped by another, that noun phrase is typically in the 'right' case: this is true of the cases just discussed, of back agreement, and of long distance agreement (Polinsky and Comrie 1999).

Second, in terms of agreement choices, we find instances where a modifier in the 'right' (nominative) case outweighs all other factors which may determine the feature value. The examples are again from Russian, and involve determiners and adjectives within quantified expressions.

7. CONCLUSION. Attempts to determine agreement entirely in terms of grammatical relations were overly optimistic. However, grammatical relations provide a useful basis for a typology. The types of extensions needed affect first the determination of the controller, and second the determination of feature values in examples of agreement options. In addition to grammatical relations we need to refer to the meaning of the clause (thematic roles and verbal semantics) and to communicative functions. On top of all this, we also need to refer to (surface) case.

\section{REFERENCES}

AISSEN, JUDITH. 1990. Towards a theory of agreement controllers. In: Paul M. Postal and Brian D. Joseph (eds), Studies in Relational Grammar 3, 279-320. Chicago: University of Chicago Press.

ANDERSON, STEPHEN R. 1984. On representations in morphology: case, agreement and inversion in Georgian. Natural Language and Linguistic Theory 2.157-218.

Bickel, BALTHASAR and YogendRA P. YADAVA. 2000. A fresh look at grammatical relations in Indo-Aryan. Lingua 110, 343-373.

BLAKE, BARRY J. 1990. Relational Grammar (Croom Helm Linguistic Theory Guides. London: Croom Helm.

Blake, BARRY J. 1994. Case. Cambridge: Cambridge University Press.

BRESNAN, JOAN. 2001. Lexical-functional syntax. Oxford: Blackwell.

BUTT, MIRIAM. 2001. Case, agreement, pronoun incorporation and pro-drop in South Asian languages. Paper read at the workshop on 'The Role of Agreement in Argument Structure', Utrecht 31.8-1.9.2001.

COMRIE, BERNARD. 1989. Language Universals and Linguistic Theory: Syntax and morphology. Oxford: Blackwell. [2nd edition, first edition 1981.]

Corbett, Greville G. 1983. Hierarchies, Targets and Controllers: Agreement Patterns in Slavic. London: Croom Helm.

Corbett, Greville G. 1998. Agreement in Slavic. WWW document prepared for the workshop 'Morphosyntax in Slavic', available at: http://www.indiana.edu/ slavconf/linguistics/index.html [January 1998].

CorbetT, GREVILle G. 2003. Agreement: the range of the phenomenon and the Principles of the Surrey Database of Agreement. In Dunstan Brown, Greville G. Corbett, and Carole Tiberius (eds.), Agreement: A Typological Perspective. Transactions of the Philological Society 101, 155-202. Oxford: Blackwell. 
DziwireK, Katarzyna. 1990. Default agreement in Polish. In Katarzyna Dziwirek, Patrick Farrell \& Errapel Majías-Bikandi (eds.), Grammatical Relations: A Cross-theoretical Perspective, 147-61. Stanford: Stanford Linguistics Association/CSLI.

Givón, TALMY. 2001. Syntax: An Introduction, I. Amsterdam: John Benjamins.

HARRIS, ALICE C. 1981. Georgian Syntax: A study in relational grammar. Cambridge: Cambridge University Press.

JOHNSON, DAVID E. 1977. On relational constraints on grammars. In Peter Cole, and Jerrold M. Sadock (eds.), Syntax and Semantics 8: Grammatical relations, 151178. New York: Academic Press.

KATHMAN, DAVID. 1995. Verb agreement and grammatical relations. In Clifford S. Burgess, Katarzyna Dziwirek, and Donna Gerdts (eds.), Grammatical Relations: Theoretical approaches to empirical questions, 153-170. Stanford: CSLI.

KEENAN, EDWARD L. 1976. Towards a universal definition of "subject". In Charles N. Li (ed.), Subject and Topic, 303-333. New York: Academic Press.

KEENAN, EDWARD L., and BERNARD COMRIE. 1977. Noun phrase accessibility and universal grammar. Linguistic Inquiry 8.63-99.

KIBRIK, ALEKSANDR E. 2003. Konstanty i peremennye jazyka. Saint Petersburg: Aletheia.

MoOre, JoHn, and DAVID PerlmutTER. 2000. What does it take to be a dative subject? Natural Language and Linguistic Theory 18.373-416.

MoRAVCSIK, EDITH A. 1978. Agreement. In Joseph H. Greenberg, Charles A. Ferguson, and Edith A. Moravcsik (eds.), Universals of Human Language IV: Syntax, 331-374. Stanford: Stanford University Press.

NiKOLAEVA, IRINA. 2001. Secondary topic as a relation in information structure. Linguistics 39, 149.

NOCENTINI, ALBERTO 1999. Topical constraints in the verbal agreement of spoken Italian (Tuscan variety). Rivista di Linguistica 11,315-339.

Palmer, F. R. 1994. Grammatical roles and relations. Cambridge: Cambridge U. P. Perlmutter, David (ed.) 1983a. Studies in Relational Grammar 1. Chicago: University of Chicago Press.

Perlmutter, DAVID (ed.) 1983b. Personal vs. impersonal constructions. Natural Language and Linguistic Theory 1, 141-200.

Perlmutter, David, and Carol Rosen (eds.), 1984. Studies in Relational Grammar 2. Chicago: University of Chicago Press.

Postal, Paul M., and Brian D. Joseph (eds.), 1990. Studies in Relational Grammar 3. Chicago: University of Chicago Press.

POLINSKY, MARIA. 1995. Non-terms in complex predicates: from incorporation to reanalysis. In: Clifford S. Burgess, Katarzyna Dziwirek and Donna Gerdts (eds.), Grammatical Relations: Theoretical approaches to empirical questions, 359-390. Stanford: Center for the Study of Language and Information.

Polinsky, MARIA, and Bernard COMRIE. 1999. Agreement in Tsez. In: Greville G. Corbett (ed.) Agreement. Folia Linguistica XXXIII/2 (special issue), 109-130.

ROBBLEE, KAREN E. 1993. Individuation and Russian agreement. Slavic and East European Journal $37,423-441$.

TOIVONEN, IDA. 2003. Grammatical functions and Inari Sami verbal agreement. Paper read at the 19th Scandinavian Conference of Linguistics, revised ms under review.

VANEK, ANTHONY L. 1970. Aspects of subject-verb agreement. Edmonton: Department of Slavic Languages, University of Alberta.

VOGEL, CARL AND BEGOÑA VILLADA. 1999. An HPSG analysis of grammatical relations, syntactic valency and semantic argument structure in Spanish psychological predicates and other instances of quirky case and agreement. Ms. Trinity College Dublin. 
Eva CSATÓ-JOHANSON

University of Uppsala, Department of Asian and African Languages, Uppsala 


\title{
CAUSATIVES, DECAUSATIVES AND LABILITY IN AGUL
}

\author{
Michael A. DANiEl, Timur A. MAISAK, AND SOlmaZ R. MERDANOVA \\ Moscow
}

The paper investigates the valency increase and decrease mechanisms in Agul (Lezgic, NakhDaghestanian). We deal with agentivization of intransitive and deagentivization of transitive predicates; in other words the problem setting is limited to the conventional causative $\sim$ labile decausative domain. The paper focuses on non-derived (i.e. non-prefixed and non-composite) Agul verbs.

1. CAUSATIVES. The only productive causativization pattern in Agul is a combination of the infinitive of the main verb with (a)q'as 'do' ('do'-causatives below). The causer NP is Ergative. With an intransitive predicate, the causee NP keeps its Nominative or Dative (with experiential predicates) marking. With a transitive predicate the causee NP is marked Apudessive (one of the spatial cases). The 'do'-causative is a default causativization pattern. It is available for all verbal lexemes except stative verbs (which do not form causatives); only 'do'-causatives are available for transitive predicates.

In intransitive predicates, there are three non-productive valency increase patterns in addition to the 'do'-causatives.

(a) A closed set of intransitive predicates have morphological causative correlates: composite forms including an $-r$ suffixed verbal stem plus the stem $t f a v V^{\prime}$ do' (cf. $\left.U X\right\} d V^{\prime}$ stop (intr)' $\left.>U x\right\} d 0$

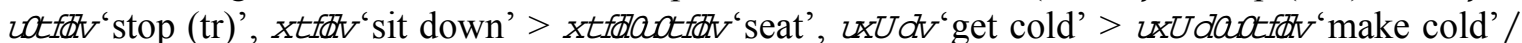

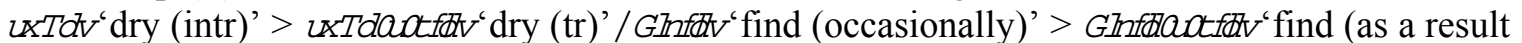

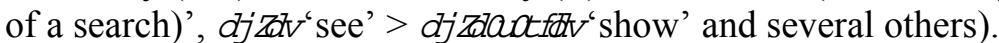

(b) A closed set of predicates may be used both in transitive and intransitive constructions; these are called labile verbs (cf. duPdV'break (tr, intr)'; $u /\left\{h V^{6} \operatorname{cook}(\mathrm{tr}\right.$, intr)'). For convenience they are viewed as pairs of formally identical verbs expressing related intransitive and transitive meanings; see the following section for details.

(c) Finally, there is a small number of lexical (suppletive) pairs causative $\sim$ decausative, including

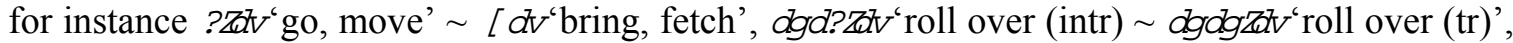

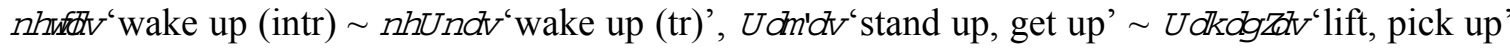
and some other.

All intransitive predicates in (a) through (c) also have the productive 'do'-causative. The two causatives of one and the same verb are contrasted semantically. Non-productive causative (composite verb or the transitive 'member' of the labile pair or the lexical causative in a suppletive pair) expresses direct, intentional causation (cf. 1a, 2a). The 'do'-causative expresses indirect or unintentional causation (cf. 1b) or has other additional semantic components (2b).

(1) tefh 'dadtffr' moisten, make wet' vs. 'do'-causative of tfh ' $d v^{6}$ 'moisten, become wet'

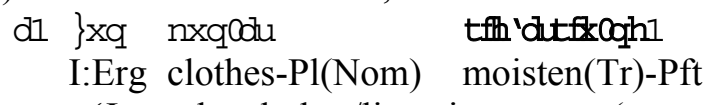

'I put the clothes/linen into water (to soak).'

$$
\begin{array}{cll}
\text { e1 3xq ornoolu } & \text { tfh'dor } & \text { texoghl } \\
\text { I:Erg foot-Pl(Nom) } & \text { moisten(Intr)-Inf } & \text { do-Pft }
\end{array}
$$

'I got my feel wet (i.e. did not prevent them from becoming wet).'

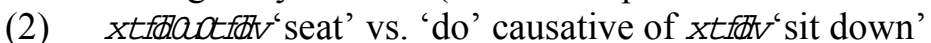

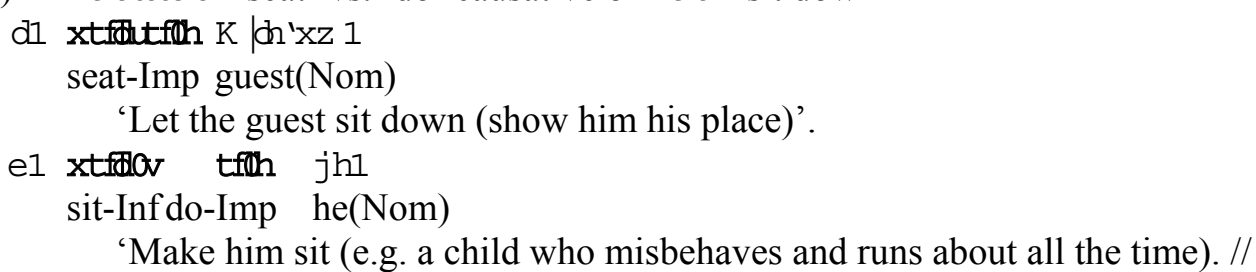


Let him wait (= sit) for a while (i.e. make him be seated while I am away).'

With labile predicates, the 'direct' causation of the intransitive meaning (the intransitive member of the pair) is expressed by the same verbal form in the transitive construction (the transitive member of the pair). As in (1) and (2), 'indirect' causation is expressed by the 'do'-causative:

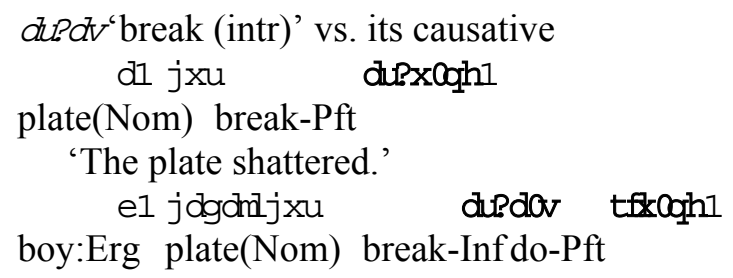

boy:Erg plate(Nom) break-Infdo-Pft

' $\approx$ The plate shattered because of the boy (for instance, he left it on an unsteady table).'

(4) dupdv'break (tr)' vs. its causative

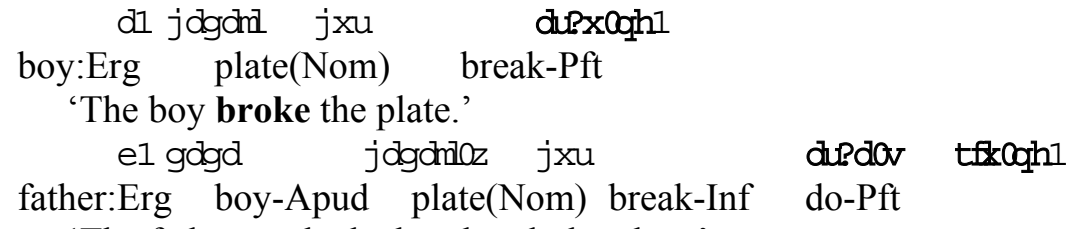

Similar contrast is observed between 'do'-causative of an intransitive predicate and its lexical causative in a 'suppletive pair':

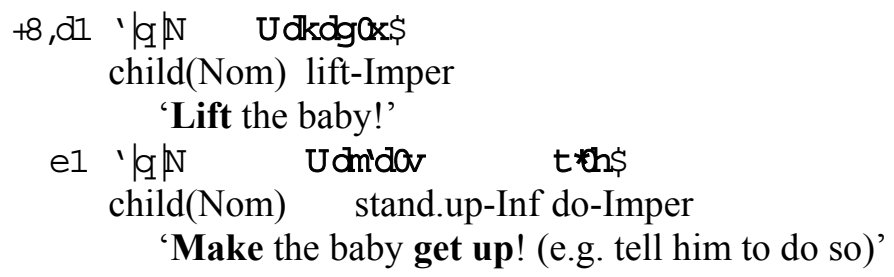

To sum up, 'direct' causation prefers morphological and lexical means, if available (morphological derivation, lability, lexical causatives), while distant causation is expressed by means of a periphrastic construction ('do'-causative).

Note, however, that for some intransitive non-labile verbs (e.g. dffot 'become full', $n \times 20$ V 'become dirty' and other) 'do'-causatives are the only causativization pattern available and express both direct and indirect causation:

(6)dl ehuKhp nxuxOghl dress(Nom)become.dirty-Pft

'The dress became dirty.'

el ux'd ehikhp nxudor tekoghl girl:Erg dress(Nom)become.dirty-Inf do-Pft

'The girl got the dress dirty (1. on purpose put it in a dirty place // 2 . unintentionally let it become dirty, was not careful enough to prevent it from becoming dirty).'

2. LABILE VERBS. Characteristic of Agul (and probably of other Lezgic languages) is a vast number of labile predicates. (We understand here lability narrowly as P-labile predicates, alias $\mathrm{S}=\mathrm{O}$ ambitransitives). At the present moment we are aware of 30 labile verbs, their share in the nonderived verbal vocabulary amounting to as much as $20 \%$. Two major groups of labile verbs may be distinguished in Agul, including:

(a) predicates designating situations which may occur spontaneously or result from actions of an

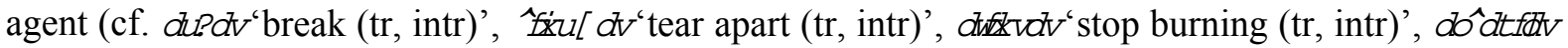
'close (tr, intr)'; cf. also $n k v^{\prime}$ 'die, kill' etc.) - the majority of the Agul labile verbs;

(b) autonomous processes which are initiated by an agent and then may go on autonomously ( $u /\left\{h v^{6}\right.$ cook (tr, intr)', $x G d v^{6}$ bake, fry (tr, intr)'); cf. also $u x\left[d v^{6}\right.$ give birth to, be born'). 
It has been observed that, cross-linguistically, the predicates in these two classes are relatively likely to be labile; cf., among others, [Dixon \& Aikhenvald (eds.) 2000: 20]. In other words, one should start looking for lability by examining the predicates within these two groups. What is peculiar about Agul, is that there are considerable discrepancies between statistical generalizations suggested by $M$. Haspelmath with regard to the choice of verbal meanings within the two classes [Haspelmath 1993]. At the same time, the set of labile verbal meanings in Agul seems to be typical of the Daghestanian; cf. [Ljutikova 2002].

Although the two domains of lability can not be delimited in a clear-cut way, these predicates behave differently, reflecting the described difference in the situational pattern. For instance, a dedicated non-intentional agent construction ('an animate participant A performs an action accidentally, without noticing it') is more available with the verbs of the first group than with the verbs of the second.

A thorough analysis of the Agul verbal vocabulary also shows that lability is not simply a lexical property of the verb, but may to a certain extent depend on its interpretation in a specific

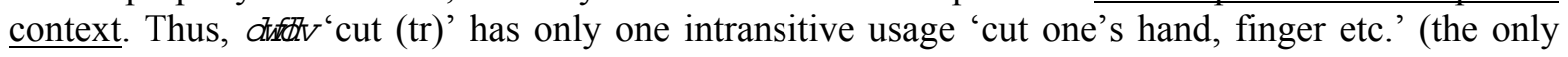
argument being the designation of the damaged body part), while $x f f(t /$ ' melt (intr), dissolve (intr)' in transitive construction is only interpreted as 'melt (tr)' (e.g. a piece of ice), but not 'dissolve (tr)' (e.g. sugar in water). Sometimes, the meaning of one of the members of the labile pair is lexicalized; thus, Xwedr 'rot', typically intransitive, when used with an Ergative agent is only interpreted metaphorically 'maltreat, vex, harass'. The literal causative sense 'let/make rot' (e.g. potatoes) may only be expressed by a 'do'-causative.

3. DeCAusatives. There is no decausative derivation in Agul. It should be noted, however, that in some types of contexts, as in fairy tales, where an inanimate patient is recategorized as animate, a transitive verb may become intransitive. These are first of all verbs designating cultural activities ('sew', 'weave', 'cut (wool)' etc.). Cf. the following examples with intransitive and (primarily) transitive predicates; the composite pronoun $x^{\wedge} x^{\wedge} \log I$ in (7a) и (8b) is an equivalent of the English itself (literally, a combination of $u$ [ 'self' in Nominative with the same pronoun in Superlative which, in Agul, encodes the role of instrument):

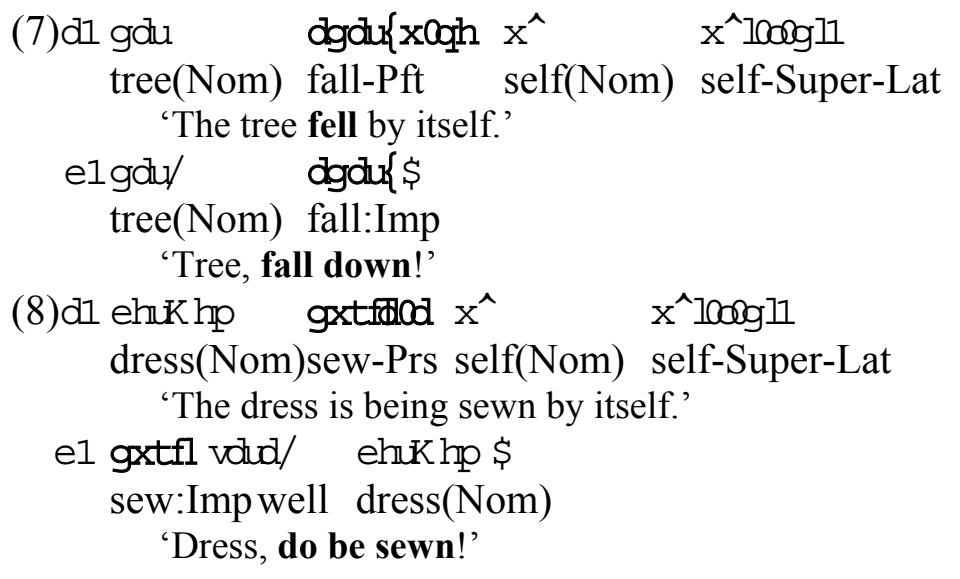

For a situation in which the agent himself is affected by the situation, such as 'eat', 'drink' etc., this kind of recategorization is virtually impossible. This phenomenon of 'contextual decausativization' shows (or at least is an argument in favor of the opinion) that the lability, i.e. a capability of a verb to be used in both transitive and intransitive contexts, is a scale rather than a binary feature. The verb 'drink' is then non-labile; 'cook' and 'break', labile, while 'sew' etc. are in between.

4. Classifying Agul PRedicates. We have started the description of valency increase/decrease mechanisms as based on the traditional classification of predicates into transitive, intransitive and labile. Using some standard contexts, one comes to a more detailed classification, zooming into the transitivity scale. For instance, only a part of intransitive verbs are used in the non-intentional agent 
construction (agent coded by Apudelative), while other verbs designate situations where an agent's control is absolutely indispensable. In other words, the degree of agentivity of intransitive verbs may be different (transitive verbs may not be used in this construction altogether).

On the other hand, only a part of transitive predicates (mainly designations of various cultural activities) allow decausative interpretation (see above). Similar contexts with verbs designating situations which affect the agent (such as 'drink') are much less interpretable.

\section{REFERENCES}

LJUTIKOVA, E. A. 2002. Kauzativy, dekauzativy i labilnyje glagoly v dagestanskikh jazykakh: opyt tipologii v predelakh jazykovoj gruppy. [Causatives, decausatives and lability in Daghestanian. A typological analysis within a genetic grouping.] Materialy k dokladu na XI Kollokviume Jevropejskogo obshestva kavkazovedov, Moscow, June 2002.

Dixon, R.M.W., and A. Aikhenvald (eds.), 2000. Changing valency: Case studies in transitivity. Cambridge: Cambridge University Press.

HASPELMATH, MARTIN. 1993. More on the typology of inchoative/causative verb alternations. In Comrie, Bernard \& Polinsky, Maria (eds.), Causatives and transitivity. Studies in Language Companion Series, 23. Amsterdam: Benjamins, 87-120. 


\title{
TYPES OF RECIPROCALS
}

\author{
ALEXIS DIMITRIADIS \\ Utrecht institute of Linguistics OTS, Utrecht
}

1. This paper addresses the interpretative options of reciprocals cross-linguistically, with particular focus on the discontinuous reciprocal construction (1a), found in numerous languages including Hebrew, Hungarian, German, Russian, Polish, Serbian, Sakha, and various Bantu languages, but not in French or Italian (Mchombo and Ngunga 1994, Siloni 2001).

(1)a. O Giannis filithike me ti Maria the John and the Maria kissed-Recip.P1

(Greek)

'John and Maria kissed each other'

b. O Giannis kje i Maria filithikan

the John kissed-Recip.Sg with the Maria

'John and Maria kissed each other'

This construction is closely associated with the semantics of necessarily symmetric events, that is, events involving a binary relationship whose two participants have necessarily identical participation (Dimitriadis 2002); I show that, contrary to prior claims, discontinuous reciprocals cannot be derived from the corresponding "simple" reciprocals. I take the semantics of necessary symmetry to be the core reciprocal meaning of this type of reciprocal; identification of the two arguments is a second, optional operation.

The discontinuous reciprocal construction is specific to a particular type of reciprocal verbs, and is impossible with other reciprocal types. It is just one of a number of specifically reciprocal properties which, while frequently found with reciprocals in genetically unrelated languages, are not found with all reciprocals. Other parametrically varying properties include: whether the reciprocal predicate is formed via a pronominal or quantificational argument with reciprocal meaning, or via an argument structure operation on the verb; if the latter, whether the argument structure operation occurs productively "in the syntax", or "in the lexicon" (Reinhart 2000, Siloni 2001); scope and scope-like effects: small clauses, derived predicates/ECM, dependent-pronoun readings, or true longdistance binding (Heim et al. 1991, Dalrymple et al. 2004, Dimitriadis 1999, Siloni 2001); whether it shows polysemy with reflexive, collective, or other meanings (Lichtenberk 1985, Kemmer 1993, Frajzyngier 1999); and (keeping in mind that we are characterizing constructions, not languages), whether this construction is the primary means of expressing reciprocal semantics in that language.

These properties raise the issue of classification of reciprocal constructions. Typologically we may speak of identifying reciprocal types and implicational relationships, while formally one must look for a set of representations, corresponding to existing reciprocal types, which can account for the observed clusterings of reciprocal properties.

2. THE DISCONTINUOUS RECIPROCAL. The two examples in (1) are, broadly speaking, synonymous: the comitative argument in (1a) is interpreted as part of the logical subject of the reciprocal verb. This makes it possible for the syntactic subject to be singular, as in example (1a), while still satisfying the semantic requirement that reciprocation must be between a plural number of participants.

Prior analyses of the construction have treated it along the lines of the descriptive summary just given, capturing in various ways the intuition that the logical subject of the reciprocal is split between the syntactic subject and the comitative argument. (Vitale 1981, Mchombo and Ngunga 1994, Siloni 2001).

A closer look, however, shows that the interpretation of discontinuous reciprocals is not quite identical to that of the corresponding simple reciprocal. The argument is based on the semantics of sentences in which the syntactic subject and/or the comitative argument denote a plural NP, as in (2a). 
(2)a. Maria und Sabine schlugen sich mit Johan.

Maria and Sabine hit each $\sim$ other with Johan

(German)

'Maria and Sabine fought with Johan.'

b. Maria, Sabine und Johann schlugen sich.

Maria Sabine and Johann hit each other

'Maria, Sabine and Johann fought.'

Example (2a) only states that Maria and Sabine fought with John, not that Maria and Sabine fought each other; but the equivalent simple reciprocal example (2b) is vague with respect to who fought with whom, allowing any combination of individuals to have fought (subject only to the condition that every individual must have been involved in some fighting). This effect cannot be derived in an analysis which treats discontinuous reciprocals as being derived from the corresponding simple reciprocal: Schwarzschild (1986) has shown that plural individuals correspond to simple unions of atomic individuals, with no intermediate structure such as might be created by the conjunction of two plural NPs; hence an analysis that combines the comitative argument with the syntactic subject of the reciprocal could never separate them again. It follows that the two are separate arguments at all stages of the derivation.

If discontinuous reciprocals do not involve an intransitivized reciprocal verb, what makes them reciprocal? I show that in most languages, reciprocal verbs that allow the discontinuous construction must denote a necessarily symmetric event, that is, an event expressing a binary relationship whose two participants have necessarily identical participation. The effect can be illustrated with implicitly reciprocal verbs in English: example (3a), involving a reciprocal pronoun, can refer to an exchange of non-symmetric kisses (e.g., on each other's cheek or hand); but the reciprocal verb in (3b) requires a symmetric kiss, with equal participation by both parties (Gleitman et al. 1996).

(3)a. John and Mary kissed each other.

b. John and Mary kissed.

In some languages, including Serbian and German, the reciprocalization operation does not always create necessarily-symmetric event verbs; but only the symmetric ones allow the discontinuous construction (example (4)). (We set aside for the moment Bantu reciprocals, which conform to a different pattern).

(4)a. Johann und Maria vergötteren sich.

Johann and Maria idolize Refl/Recip (German)

'Johann and Maria idolize themselves/each other.'

b. *Johann vergöttert sich mit Maria.

I propose that the function of the core reciprocalization operation in verbs of this type does not detransitivize the base verb, but creates a necessarily symmetric predicate. The roles of the two participants in an event become necessarily identical, but the participants remain distinct. Discontinuous reciprocals take two arguments, while simple reciprocals undergo a second, optional operation, which causes the two semantic arguments of the reciprocal to be identified. An informal definition of "symmetricization" is given in (5). We can then write an abbreviated semantics for verbal reciprocalization as in (6), modeled on the analysis of Heim et al. (1991).

(5) $\operatorname{Symm}(V)(x, y)$ iff $\exists e(V(e, x, y) \& V(e, y, x))$

(E.g., $x$ symmetrically-kisses $y$ if some event $e$ is both an event of $x$ kissing $y$ and of $y$ kissing $x$ ).

$$
\operatorname{Recip}(V)=\lambda R \lambda S \forall x \varepsilon S \forall y \varepsilon R(x \neq y \rightarrow \operatorname{Symm}(V)(x, y))
$$

3. TOWARD A TYPOLOGY. A number of different principled schemes for the classification of reciprocal constructions have been proposed. Morphologically, we can distinguish whether a reciprocal predicate is formed via a pronominal or quantificational argument with reciprocal meaning, or via an argument structure operation on the verb; and if the latter, whether the argument structure operation occurs productively "in the syntax", or "in the lexicon" (Reinhart 2000, Siloni 2001, Plank 2002). 
Interpretationally, we can ask whether we are dealing with a dedicated reciprocal construction, or with one that is polysemous between a reciprocal and a reflexive, collective, or other meaning (Frajzyngier 1999); alternatively, we can classify reciprocals according to the reciprocal and reciprocallike situation types they allow (Lichtenberk 1985, 1999). Finally, keeping in mind that we are classifying constructions, not languages, we should ask whether a reciprocal construction is the primary means of expressing reciprocal semantics in that language.

I know of no existing classification of reciprocals that corresponds to the distribution of reciprocal properties. Bantu reciprocals, in particular, systematically cut across the expected categories. They are formed by a demonstrably derivational verbal morpheme but share properties that are usually associated with each of the three morphological types; they do not show reflexivereciprocal polysemy, but they allow many of the same constructions (such as discontinuous reciprocals) as polysemous reflexive-reciprocal verbs in Greek, Serbian and Hebrew (Dalrymple et al 1994, Dimitriadis 2002).

\section{REFERENCES}

Dalrymple, Mary, Sam A. Mchombo, and Stanley Peters. 1994. Semantic similarities and syntactic contrasts between Chichewa and English reciprocals. Linguistic Inquiry 25, 145-163.

DIMITRIADIS, ALEXIS. 1999. Reconciling dependent plurals with each other. In Tanya Matthews and Devon Strolovitch (eds.), Proceedings of SALT 9. Ithaca, NY: CLC Publications.

DIMITRIADIS, ALEXIS. 2002. Discontinuous reciprocals and symmetric events. Paper presented at the Anaphora Typology Workshop on Reciprocals, Utrecht University.

FRAJZYNGIER, ZYGMUNT. 1999. Coding of the reciprocal function: Two solutions. In Frajzyngier, Zygmunt, and Traci S. Curl (eds.), Reciprocals: Forms and functions. Typological Studies in Language, 41, 179-194.

FrAJZYNGIER, ZYGMUNT, and TRACI S. CURL (eds.), 1999. Reciprocals: Forms and functions. Typological Studies in Language 41. Amsterdam: John Benjamins.

Gleitman, Lila R., Henry Gleitman, Carol Miller, and Ruth Ostrin. 1996. Similar, and similar concepts. Cognition 58, 321-376.

HeIm, IRENE, HOWARD LASNIK, and ROBERT MAY. 1991. Reciprocity and plurality. Linguistic Inquiry 22, 63-101.

Kemmer, SuZANNE. 1993. The middle voice. Typological Studies in Language, 23. Amsterdam: John Benjamins.

LiCHTENBERK, FRANTISEK. 1985. Multiple uses of reciprocal situations. Australian Journal of Linguistics 5, 19-41.

LiCHTENBERK, FrANTISEK. 1999. Reciprocals without reflexives. In Frajzyngier, Zygmunt, and Traci S. Curl (eds.), 1999. Reciprocals: Forms and functions. Typological Studies in Language, 41. 31-62.

MCHOMBo, SAm A., and ARmindo S. A. NGUNGA. 1994. The syntax and semantics of the reciprocal construction in Ciyao. Linguistic Analysis 24, 3-31.

PLANK, FRANS. 2002. Thoughts on the origin, progress, and pro status of reciprocal forms in Germanic, occasioned by those of Bavarian. Ms., Universit"at Konstanz.

REINHART, TANYA. 2000. The theta system: Syntactic realization of verbal concepts. OTS Working Papers in Linguistics 00,01/TL. Utrecht institute of Linguistics OTS.

SChWARZSCHILD, Roger. 1996. Pluralities. Studies in Linguistics and Philosophy 61. Dordrecht: Kluwer.

SilonI, TAL. 2001. Reciprocal verbs. In Yehuda N. Falk (ed.), Proceedings of the Israel Association of Theoretical Linguistics. Online publication, available at http://atar.mscc.huji.ac.il/_english/IATL/17/.

VitALE, ANTHONY J. 1981. Swahili syntax. Dordrect: Foris. 


\title{
ASPECTUAL COMPOSITION: NEW EVIDENCES
}

\author{
PHILIP I. DUDCHUK \\ Moscow State University
}

1. THEORETICAL ISSUE OF THE TALK. The formal semantics introduced the idea of compositionality suggested first in (Frege 1892) into researches of the aspectual meanings of a clause. The theories of the aspectual composition (Krifka 1986, 1992, 1998; Verkuyl 1999, 2001, 2002; Filip 1999; Partee 1995; Dowty 1988, 1991) showed that the telicity feature of a clause is derived from the similar features of its constituents. They appear to be the feature of the quantification of the internal object and the eventuality type of the verb (dinamic or stative). The classic approach in (Vendler 1967) suggests that the whole set of aspectual features is determined for each verb in the lexicon, and the idea of compositionality makes the modern theories differ from the Vendlerian one.

Predication (1a) is atelic, and (1b) is telic, this fact is proved by the tests with durative adverbials.

(1) English

a. John ate [apples $]_{[-\mathrm{QUANT}]}\{$ for three hours/*in three hours .

b. John ate [the apples $]_{[+ \text {QUANT }]}\left\{{ }^{*}\right.$ for three hours/in three hours $\}$.

Such a changing of telicity feature as in (1) seems not to be able to be explained in terms of Vendler's aspectual classes. In the compositional framework it is argued that this changing takes place because of the difference between quantificational features of internal objects in (1a) and (1b). Nowadays there are two the most elaborate theories: the PLUG theory developed by Henk Verkuyl and the mereological approach of Manfred Krifka. These theories analyze the quantificational properties of the internal object differently. Now I will expose the main ideas of the two theories.

1.1. The PLUG TheOry, HenK J. FerkuYl (1999, 2001, 2002). The main assumption of the theory is that each constituent of the predication is provided with a feature that is able to change its value and may be either positive or negative.

Thus each of the predicate's arguments is provided by the [ $\alpha \mathrm{SQA}]$ feature opposition, 'specified quantity of A', where A is the denotation of the head noun. Such NPs as a house, two houses, the houses are [+SQA], and such ones as houses, milk are [-SQA].

The verb is provided with the [ $\alpha$ ADDTO] feature opposition, additivity of the situation described by the verb; normally, non-stative (dynamic) verbs are [+ADDTO], dynamic verbs are [ADDTO] specified.

Finally, on the VP and the whole predication there is $[ \pm T]$ feature, the terminativity that indeed provides the telicity of the predication. Thus in Verkuyl's theory the structure of the predication is as on Figure 1.

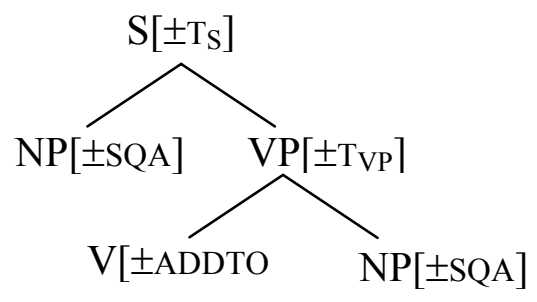

FIGURE 1

The value of $[ \pm T]$ feature is not obtained in the very beginning (like other features in the tree), but is calculated from daughter nodes by the Plus Principle (Verkuyl 2001: 23): the value of $\left[ \pm \mathrm{T}_{\mathrm{S}}\right]$ feature is positive iff the values of all other features in the tree are positive. 
1.2. Mereological APPROACH, MANFred Krifka (1986, 1992, 1998). M. Krifka captures the difference between telic and atelic predicates and predications by means of the notions cumulativity and quantization. His theory is called mereological approach.

Predicate is cumulative if it is additive, i.e. whenever it applies to the entities $x$ and $y$, it also applies to the sum $x \oplus y$. If the predicate does not possesses this property, it is quantized.

$$
\begin{aligned}
& \text { additivity } \\
& \mathrm{ADD}(\mathrm{P}) \equiv \forall x \forall y[\mathrm{P}(x) \wedge \mathrm{P}(y) \rightarrow \mathrm{P}(x \oplus y)]
\end{aligned}
$$

Although the cumulative predicates have the property of divisivity: a predicate is divisive iff whenever $\mathrm{P}$ applies to $\mathrm{x}$, then it must also apply to any $\mathrm{x}$ ' that is properly included in $\mathrm{x}$.

(ii) divisivity

$$
\operatorname{DIV}(\mathrm{P}) \equiv \forall x \forall x^{\prime} \subset x\left[\mathrm{P}(x) \rightarrow \mathrm{P}\left(x^{\prime}\right)\right]
$$

The examples of cumulative predicates: voda (rus. 'water'), apples, du sucre (fr. 'sugar'), etc. The examples of quantized predicates: the apples, dom (rus. 'house'), a cup.

In fact, the events appear to be in the same way. The verbal predicate speak is cumulative, because it is true that if the events $e$ is speak and the events $e^{\prime}$ is speak, that $e \oplus e^{\prime}$ is also a speaking. On the other hand, the verbal predicate flash is quantized, because the event flash $\oplus$ flash is not a flashing.

So, Krifka formulates the following generalization: a predicate is atelic iff it is cumulative; $a$ predicate is telic iff it is quantized.

The further researches required the adopting of the notion incrementality. A predicate is incremental if it stands in one-to-one relation with its arguments. Thus, the event eat apples is incremental, because when someone eats apples, each part of this situation corresponds to a part of apples that are eaten at the moment. When the whole denotaion of the argument apples disappeares, the situation will be naturally terminated. The internal object (apples) is called the gradual patient (Krifka 1986, 1992), or the incremental theme (Dowty 1988, 1991).

Finally, the principle of the aspectual composition is formulated:

An episodic verb (in sentences denoting single eventualities) combined with a quantized Gradual Patient argument yields a quantized complex verbal predicate, while with a cumulative Gradual Patient argument it yields a cumulative complex verbal predicate (Filip 1991: 94).

2. DATA. The aspectual composition in French, German and in the most part of Turkic and NakhDaghestanian languages is similar with the English one; the fact is illustrated in (1). ${ }^{11}$

(2) French

$$
\begin{aligned}
& \text { a. Jean a=mangé [les pomme-s }] \quad\{* 3 \text { heures / en } 3 \text { heures }\} \\
& \text { Jean AUX=eat DEF apple-PL \{for } 3 \text { hours / in } 3 \text { hours\} } \\
& \text { 'Jean ate the apples.' } \\
& \text { b. Jean a=mangé [des pomme-s] }\{3 \text { heures } / * \text { en } 3 \text { heures }\} \\
& \text { Jean AUX=eat INDEF apple-PL \{for } 3 \text { hours/ in } 3 \text { hours } \\
& \text { 'Jean ate apples.' }
\end{aligned}
$$

However, there are languages the data of which cannot be analyzed by the theories exposed in the section 1 and requires the further elaboration of the theories. In Russian the interaction of the telicity and quantization features is not the same as in English: if a Russian predication is quantized, its internal object is subjected to the universal quantification. Thus, in (3) NP jabloki ('(the) apples') is specified "by context" (SQA = Specified Quantity of A - (Verkuyl 1999)).

\footnotetext{
${ }^{11}$ Glosses AND ABBREVIATIONS. ACC = accusative, ATI = atelic interpretation, AUX = auxiliary verb, DEF = definite article, DUR $=$ durative, $\mathrm{f}=$ finite stem, $\mathrm{INDEF}=$ indefinite article $=\mathrm{IPFV}=$ imperfective, $\mathrm{o}=$ objective conjugation, $\mathrm{PF}=$ perfective, $\mathrm{PL}=$ plural, $\mathrm{PLo}=$ plural of the object, $\mathrm{PST}=$ past, $\mathrm{s}=$ subjective conjugation, $\mathrm{TI}=$ telic interpretation.
} 
(3) on s-je-1 [jablok-i $]_{[+S Q A]}$

he PF-eat-PST apple-PL

'He ate the apples.'

The upgrade of the theory was suggested by H. Verkuyl. He supposed that in Russian the scope of the perfective prefix is the whole VP, including the internal object. M. Krifka offers another solution: the prefix is analyzed as a lexical quantifier the scope of which is the incremental theme. But the both approaches seem to fail to explain the obtaining of (4).

(4) Russian

a. Boris po-risova-l kvadrat-y.

Boris PF-draw-PST square-PL

'Boris drew squares.'

b. Boris pro-pe-1 pes'n-i vesj den'.

Boris PF-song-PST song-PL all day

'Boris sang songs all the day.'

c. Boris s-jed-a-l každijd'en' tarelk-u fasol'-i. ATI

Boris PF-eat-IPFV-PST every day plate-ACC been-GEN

'Every day Boris ate a plate of beens.'

In (4a) there is a prefix po on the VP but it does not provide any telicity, but seems to be the function that takes a part of an event.

In (4b) the situation is about to be the same as in (4a) but pro with the scope over the VP requires the object every day.

In (4c) we have a set of subevents eat a plate of beens that is interpreted as atelic.

The discussion of these problems was provided by S. Tatevosov (2002 and 2003).

Besides, in Hungarian the verbal prefix applies to the incremental theme and subjects it to the universal quantification as illustrated in (5d) where the NP of the internal object is not specified and so is not quantized.

(5) Hungarian

a. almá-k-at

evett

apple-PL-ACC eat.PST.s

'He ate apples.'

b. az almá-k-at ette

DEF apple-PL-ACC eat.PST.o

'He was eating the apples.'

c. az almá-k-at meg-ette

DEF apple-PL-ACC PF-eat.PST.o

'He ate the apples.'

d. *almá-k-at meg-evett

apple-PL-ACC PF-eat.PST.s

In Nenets the interaction between the properties of the predicate and its arguments is the same as in Russian and Hungarian, the internal object is also universally quantified. However, the telicity is not caused by a prefix like in Russian, but it is atelicity that is caused by durative marker as illustrated in (6b). There is neither operator nor quantifier with the scope over the VP, so there seems to be no knowledge about why a Nenets predication is (a)telic neither in Verkuyl's nor Krifka's terms.

(6) Nenets

a. plgdnquljd woohmogd+0vJ,

he book.ACC.PL read.PLo-3SG(-PST)

'He read the books.' 
b. plgd nqJljd
he book.ACC.PL read-DUR.f-3SG(-PST)
'He read books.'

ATI

3. CONCLUSION. The theories discussed in this talk seem to predict a great deal of facts in different languages. It appeared however that there is some data got in the field that cannot be analyzed by the theories of the aspectual composition. It seems that these theories are to be modified significantly so they predict correctly the telicity of predications in such languages as Nenets.

\section{REFERENCES}

Dowty, D. R. 1988. Thematic Proto-Roles, Subject Selection, and Lexical Semantic Defaults, ms. (Paper presented at the 1987 LSA Colloquium. San Francisco).

DowTY, D. R. 1991. Thematic Proto-Roles and Argument Selection. Language 67, 547-619.

FILIP, H. 1999. Aspect, Eventuality Types and Noun Phrase Semantics. New York, 81-149.

Frege, G. 1892. Über Sinn und Bedeutung. Zeitschrift für Philosophie und Philosophische Kritik. No. 100, 25-50.

KRIFKA, M. 1986. Nominalreferenz und Zeitkonstitution. Zur Semantik von Massentermen, Individualtermen, Aspektklassen. Doctoral Thesis, The University of Munich.

KRIFKA, M. 1992. Thematic Relations as Links between Nominal Reference and Temporal Construction. Sag, I. A. and A. Szabolsci (eds.), Lexical Matters, pp. 29-53.

KRIFKA, M. 1998. The Origins of Telicity. Rothstein, S. (ed.). Events and Grammar. Dorbrecht/Boston/London: Kluwer Academic Publishers, pp. 197-235.

PARTEE, B. H. Quantificational Structures and Compositionality. Bach, E. et al. (1995), 541-601.

TATEVosov S.G. 2003. Tipologija vida i russkij delimitative. (Presentation at the Moscow Typological Society 2003, March 11).

TATEVosov, S.G. 2002. The parameter of actioanlaity. Linguistic typology 6, 317-401.

VENDLER, Z. 1967. Verbs and Times. Philosophical Review 56, pp. $143-160$.

VerkUYL, H. J. 1999. Aspectual Issues. Structuring Time and Quantity. CSLI Lecture Notes, 98, Stanford, California.

VERKUYL, H. J. 2001. A Young Person's Guide to the Theory of Tense and Aspect, 15-43, 55-75.

VERKuYL, H. J. 2002. Formal Semantics Course. Lectures delivered in the St. Petersburg State University, pp. 71-109. 


\title{
MODALS, PSEUDOCLEFTS AND THE SUBJECT ROLE
}

\author{
KRISTIN M. EIDE \\ Norwegian University of Science and Technology (NTNU)
}

1. THE ROOT VS. EPISTEMIC DISTINCTION. In many of the world's languages, modals have what seems to be a two-faced value. Thus, a modal typically has a "root reading", where it is taken to denote e.g. some sort of complex social relation (obligation and permission are cases in point), and an "epistemic (or metaphysical, or evidential) reading", whereby "the speaker signals his attitude to the truth-value of the proposition" (Palmer 2001). The Norwegian data in (1) illustrates the phenomenon.

(1) Jon må være på kontoret

Jon must be in office-DEF

'Jon must be in his office'

(a) Jon is obligated to be in his office (root reading).

(b) It must be the case that Jon is in his office (epistemic reading).

2. THE ARGUMENT STRUCTURE OF MODALS: CONTROL VERSUS RAISING? There exists a comprehensive literature on the argument structure of modals. A widespread analysis, implemented in various frameworks, assumes that an epistemic modal is best construed as a one-place predicate taking the proposition as its argument, whereas root modals denote two-place predicates, construed as a relation between an agent (e.g. Jon) and an action.

(2) epistemic modal: must (p) root modal: $\quad$ must $(\mathrm{J}, \mathrm{a})$

In the generativist framework, this analysis has a long tradition, starting with Ross (1967). It is often referred to as the "control-versus-raising" (CvR) analysis, since root modals are analysed as control verbs, whereas epistemic modals are analysed as raising verbs. To illustrate; in the root modal construction in (3a), the subject $J o n$ receives its thematic role $(\theta-$ role) from the root modal and controls the PRO subject of the downstairs verb. In the epistemic modal construction in (3b), the subject Jon receives its thematic role from the downstairs verb and moves to fill the subject position of the epistemic modal verb, but receives no subject role from the modal.

(3)

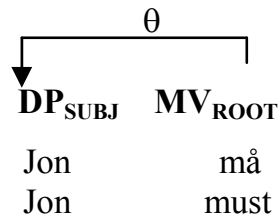

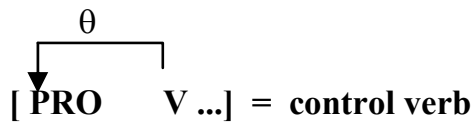

være på kontoret

be in office-DEF

'John must be in his office (John has an obligation to be in his office)'

b.

$\begin{array}{lr}\mathbf{e} & \mathbf{M V}_{\text {EP }} \\ \text { Jon }_{\text {I }} & \text { må } \\ \text { Jon } & \text { must }\end{array}$

'John must be in his office (it must be the case that John is in his office)'

Now, the CvR analysis has a range of predictions (cf. 4), in particular pertaining to the properties of the subject in a modal construction. Control verbs (e.g. hope) take rational agents as their subjects, whereas raising verbs (e.g. seem) impose no selectional requirements on their subjects. Thus, if root modals are control verbs, we would not expect them to take e.g. expletive subjects and other subject types assumed to occur in non-thematic positions (cf. Thráinsson and Vikner 1995 and many others), but we would expect raising verbs to do so. Moreover, raising verbs are typically scopally ambiguous, capable of scoping over the subject or under it, unlike control verbs, where the subject always takes the wider scope. All things equal, we would expect root modals to pattern with control verbs and epistemic modals to pattern with raising verbs in this respect. 


\section{(4) Predictions of the CvR analysis}
a. Allow expletive subjects
b. Allow weather-det/Dad 'it' subjects
c. Allow idiom-chunk subjects
d. Allow quirky (non-nominative) subjects (Icelandic)
e. Allow passive complement with inanimate subject
f. Display subject-modal scope ambiguity

$\begin{array}{cc}\text { Epistemic modals } & \text { Root modals } \\ \text { yes } & \text { no } \\ \text { yes } & \text { no } \\ \text { yes } & \text { no } \\ \text { yes } & \text { no } \\ \text { yes } & \text { no } \\ \text { yes } & \text { no }\end{array}$

However, these predictions are not borne out (cf. Eide 2002). Although dispositional modals (denoting ability and volition) behave as expected on the CvR analysis, deontic modals (denoting permission and obligation) pattern instead with raising verbs, not control verbs, with respect to the properties listed in (4). Thus, (5) illustrates root modals with expletive subject (5a), weather-it subject (5b), idiom-chunk subject $(5 \mathrm{c})$, quirky subject $(5 \mathrm{~d})$, passive complement with inanimate subject $(5 \mathrm{e})$ and subject-modal scope ambiguity (5f). Our findings are summed up in (6).

\section{(5) Root modals with raising verb properties}

a. Det skal bestandig være minst to voksne til stede. there shall always be at-least two adults at place

'There should always be at least two adults present.'

b. Nå bør det snart regne; gresset er så tørt. now should it soon rain; the grass is so dry

'It ought to rain soon; the grass is so dry.'

c. M.h.t. Jon, så kan fanden ta ham!

'As for John, the devil may take him (= permission).'

(Idiom: Fanden ta Jon! Devil-def take-OPTATIVE Jon)

d. Umsækjandann verður að vanta peninga the-applicant-ACC must to lack money

'The applicant must lack money

(in order to apply for this grant).'

e. Maten må/ skal/ kan/ bør bli servert snart.

'The food must/ will/ may/ should be served soon (epistemic/root = OK).'

f. Noen søkere bør/kan/må/skal søke igjen.

'Some applicants should/may/must/will apply again.'

i) There are some applicants and they should/may/must/will apply again.

ii) It is preferred/allowed/necessary/intended that some applicants apply again.

(6) Our findings concerning modals and the properties in (4)

\section{Raising verbs, epistemic modals}

\& deontic root modals: modals:

a. Allow expletive subjects

b. Allow weather-det 'it' subjects

c. Allow idiom-chunk subjects

d. Allow quirky subjects (Ic.)

e. Allow passive compl. with inanimate subject

f. Display subject-modal scope ambiguity

$\begin{array}{ll}\text { yes } & \text { no } \\ \text { yes } & \text { no } \\ \text { yes } & \text { no } \\ \text { yes } & \text { no } \\ \text { yes } & \text { no } \\ \text { yes } & \text { no }\end{array}$

That is, our findings so far suggest that deontic root modals pattern with raising verbs (i.e. one-place predicates), not with control verbs. However, this picture changes when we look at the behavior of modals in pseudoclefts. 
3. MODALS IN PSEUDOCLEFT CONSTRUCTIONS. Although versions of the CvR analysis keep surfacing in the literature, it has had a lot of critics over the years. A number of authors (e.g. Pullum and Wilson 1977, Wurmbrand 1999) have suggested instead that all modals are raising verbs. This analysis is also problematic for certain classes of modals. As listed in (6), dispositional root modals behave like control verbs in all types of constructions, whereas deontic modals seem to pattern with raising verbs. On closer scrutiny, however, deontic modals constitute something of a paradox. Although their properties (cf. 6) reveal their resemblance to rasing verbs, it is still possible to construe them as two-place predicates semantically. Thus, it is possible to argue that (7) has two distinct deontic (i.e. nonepistemic) readings, one where Jon is subject to the obligation (what is sometimes called the subjectoriented reading), and another where somebody else (not mentioned) is subject to the obligation, e.g. Jon's babysitter, some arbitrary person, or perhaps no-one (i.e. the proposition-scope deontic reading).

(7) Jon må spise grøten sin.

Jon must eat porridgeDEF his

'John must eat his porridge'

(a) Jon has an obligation to eat his porridge (subject-oriented reading).

(b) It is required that Jon eats his porridge (proposition-scope reading).

Certain authors, e.g. Wurmbrand (1999), have claimed that the proposition-scope deontic reading which is easily construed as a one-place predicate relation, just like epistemic modals (cf. 2 above), is the basic reading. The subject-oriented reading arises in many cases because of contextual/pragmatic factors. This two-place reading, she claims, does not mirror the semantic representation of a modal, and it is always possible to force a non-directed reading under any circumstances. However, this is incorrect. There is one construction type where only the subject-oriented (two-place) reading is allowed, notably where the complement of the modal undergoes pseudocleft. Raising verbs are typically ungrammatical in this construction ( $8 \mathrm{ab})$, whereas control verbs are fine (8cd). Root modals are fine in this construction, too, as long as the subject-oriented reading is the natural reading (8ef). When this reading is unnatural, and the proposition-scope reading seems to be the only natural reading, the construction is ungrammatical (8gh). Our findings are summed up in (9).

(8)
a. * Det Jon viste seg, var å være inkompetent.
it Jon showed self, was to be incompetent
(Int.: 'What John turned out to be, was incompetent.')
b. * Det Marit antas, er å være uærlig.
it Marit suppose-PASS, is to be dishonest
('What Marit is supposed to be, is dishonest.')
c. Det Jon prøvde, var å være ærlig.
it Jon tried, was to be honest
'What John tried, was to be honest.'
d. Det Marit håpet, var å få snakke med ham.
it Marithoped, was to get talk to him
'What Marit hoped (for), was to get to talk to him.'
e. Det Marit må, er å snakke med ham.
it Marit must is to talk to him
'What Marit must (do), is to talk to him.'
f. Det du skal, er å pusse tennene.
it you shall is to brush teeth-DEF
'What you will (do), is to brush your teeth.'
$\begin{array}{cllll}\text { g. *Det en kvinne bør, } & \text { er å bli vår } & \text { neste statsminister. } \\ \text { it a woman should, } & \text { is to be our } & \text { next prime minister. }\end{array}$
(Intended: 'What should happen is that a woman becomes our next prime minis ter.')
$\begin{array}{clll}\text { h. *Det apene ikke må, er å mates } & \text { av besøkende } \\ \text { it the monkeys not must, } & \text { is to feed-PASSive by visitors }\end{array}$

it the monkeys not must, is to feed-PASSive by visitors


(Intended: 'What must not take place is that the monkeys are fed by visitors.')

\section{(9) Readings available for Mainland Scandinavian modals:}

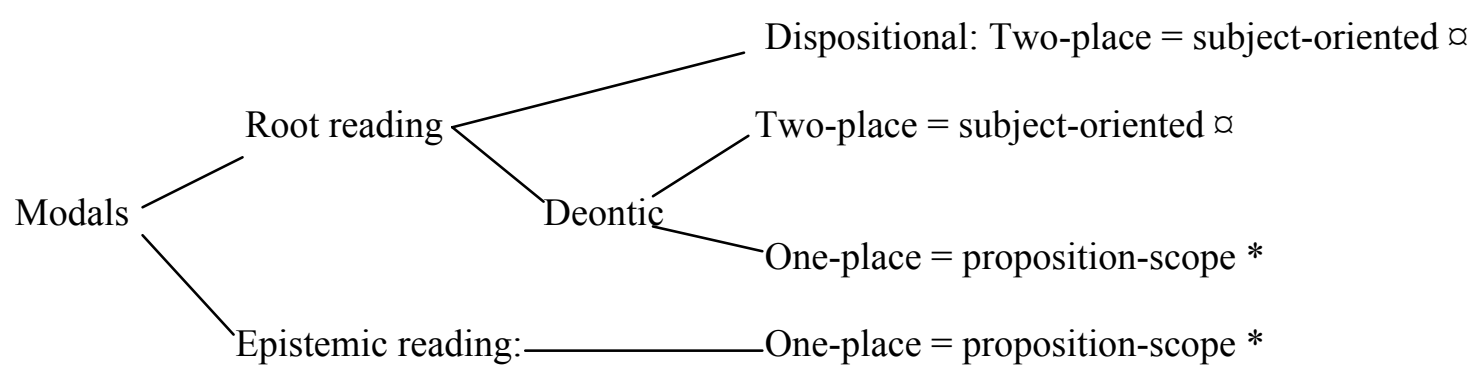

a: Accepts a pseudoclefted complement; * rejects a pseudoclefted complement.

4. THE ARGUMENT STRUCTURE OF MODALS. The CvR analysis gives the right predictions when we look at dispositional modals (denoting ability and volition) and epistemic modals exclusively. Dispositional modals are always construed as two-place predicates, and they behave like control verbs syntactically. Epistemic modals are always construed as one-place predicates and they pattern with raising verbs syntactically. However, deontic modals constitute a problem and a paradox for the CvR analysis and the Wurmbrand analysis alike. Deontic modals patterns with raising verbs in some respects and with control verbs as regards other properties. I will claim that the only way to resolve this paradox, is to analyse deontic modals as predicates with an ambiguous argument structure, they sometimes select for a subject role and sometimes not.

However, to account for the argument structure of modals in an exhaustive way, it is necessary to describe their semantics on two different levels (cf. Bierwisch and Lang 1986, developing a twolevel semantics for adjectives). The level Semantic Form (SF) specifies the semantics relevant for syntax (e.g. the number of syntactically realised arguments), whereas the level Conceptual Structure (CS) contains the solely conceptually relevant information (e.g. the source of the modality). By means of this two-level system I show how the obligation-reading of deontic modals is not part of the semantic matrix of the modal, but arises as a result of one specific combination of SF- and CS arguments.

\section{REFERENCES}

BIERWISCH, MANFRED, and EWALD LANG. 1989. Somewhat Longer - Much Deeper - Further and Further: Epilogue to the Dimensional Adjective Project. In B. Bierwisch and E. Lang (eds.), Dimensional Adjectives - Grammatical Structure and Conceptual Interpretation, Springer Series in language and Communication, Springer-Verlag, Berlin.

EIDE, KRISTIN M. 2002. Norwegian Modals, doctoral dissertation, Linguistics dept. NTNU, Trondheim.

PALMER, FranK R. 2001. Mood and Modality. Cambridge: Cambridge University Press.

PULLUM, GEOFFREY, and DEIRDRE WILSON. 1977. Autonomous syntax and the analysis of auxiliaries, Language 53, 741-788.

Ross, JOHN R. 1969. Auxiliaries as main verbs. In W.Todd (ed.), Studies in Philosophical Linguistics, 77-102, Great Expectations, Evanston, Illinois.

THRAINSSON, HÖSKULDUR, and STEN VIKNER. 1995. Modals and Double Modals in the Scandinavian Languages, Working papers in Scandinavian Syntax 55, 51-88. Department of Scandinavian Linguistics, Lund University.

WURMBRAND, SUSI. 1999. Modal verbs must be raising verbs, In Sonya Bird, Andrew Carnie, Jason D. Haugen and Peter Nordquest (eds.), Proceedings of the 18th West Coast Conference on Formal Linguistics (WCCFL18), 599-612. 


\title{
CONTINUITY OF INFORMATION STRUCTURING STRATEGIES IN EASTERN KHANTY. DEFINITENESS/TOPICALITY
}

\author{
ANDREJ FILTCHENKO \\ Rice University / Tomsk State Pedagogical University, Tomsk
}

The presentation addresses the issue of structural cohesion in language. Based on the analysis of discourse-pragmatic functions and propositional-semantic content of examples in the narrative, it illustrates the continuity in morphosyntactic means in the system that are used for structuring of information: case, transitivity, voice, agreement, elision, possessive marking, non-finite forms and relative clauses. Selected methodology includes contrastive contextual analysis, attending to the information structure and extra-linguistic metadata, in the general cognitive-functional framework.

Based on narrative discourse analysis of Eastern Khanty, an endangered Siberian native FinnoUgric language, it is hypothesized, that a wide cognitive faculty facilitating the structuring of information specifies the roles and interrelations of the participants in a complex negotiation of the pragmatic features (identifiability, activation, topicality), semantic properties (agentivity), pragmatic/locutionary pressures (power/control, volition, authority) formally manifested in the choice of grammatical resources available in the system. It follows from the analysis of the host of the interrelated features of a set of constructions that specific conglomerates of the system's grammatical resources strongly associate with specific conglomerates of pragmatic-functional and semantic properties. The holistic analysis of pragmatic-functional, semantic and structural properties of all the participants in their interaction in the narrative discourse, is viewed as particularly revealing.

1. The syntax of Eastern Khanty generally correlates to SOV word order patterns. In the discourse pragmatic organization, a new referent is activated as topic by a full NP and maintained by a free pronoun in the S/A relation and by S/A-V agreement. Once identifiable as the pragmatic center, the referent continues in this function expressed by elision and by S/A-V agreement. Whenever overt, $\mathrm{S} / \mathrm{A}$ is pragmatically marked as a topic-shift or a presentational clause.

(i) In active-direct clauses verb transitivity and O-argument definiteness is marked by the $\mathrm{O}-\mathrm{V}$ agreement inflection governed by the interaction of a host of the referent's pragmatic features (identifiability, activation, topicality) and semantic properties (agentivity), as revealed in the syntactic behavior of the argument:

- word order/omissibility: the $\mathrm{O}$ arguments that co-occur with $\mathrm{O}-\mathrm{V}$ agreement may be more flexible in its constituent position, or altogether elided, whereas the $\mathrm{O}$ argument not co-occurring with $\mathrm{O}-\mathrm{V}$ agreement is rigid in its overt SOV position.

- O-argument focus clauses and WH-question/answer sequences: only S/A-V agreement is attested, thus proving that $\mathrm{O}-\mathrm{V}$ agreement is contingent upon $\mathrm{O}$ 's pragmatic status, i.e. identifiability/activation, topicality.

- subject-controlled embedded participial clauses: non-finite V has co-reference agreement with the S/A referent of the non-finite clause, if this S/A referent is high on the pragmatic identifiabillty/activation (Lambrecht, 1994; Nikolaeva, 1999).

- relative subject agreement: - attested in sentences with the S/A-Rel expressed by a free pronoun, rather than a full NP, which correlates to the referent's pragmatic status: identifiability/activation.

- reflexivization: - can be controlled by the S/A or O argument that co-occurs with the O-V agreement on the predicate, while the $\mathrm{O}$ argument without $\mathrm{O}-\mathrm{V}$ agreement cannot control it. Thus, the reflexive/possessive marker on the NP possessed may refer both to the S/A and O in case of $\mathrm{O}-\mathrm{V}$ agreement, whereas in case of the absent $\mathrm{O}-\mathrm{V}$ agreement this affix may only refer to the S/A. Functional/structural similarity between the relative and the possessive constructions is widely attested in typological literature, as invoking a relation to one entity for identification of another (Langacker, 1993).

- possession constructions: - demonstrate agreement patterns similar to those of relative clauses, i.e. while the pronominal head-possessor triggers the agreement on the possessed NP, the NP pos- 
sessor does not, manifesting, once again, the relevance of the pragmatic status of the referent: identifiability/activation.

2. The Eastern Khanty non-canonical agent-marking constructions (ergative \& passive) appear a marginal construction type, describing events with more than one closely associated discourse referent with competing topicality status simultaneously occupying the stage in the narrative. The actual functional-semantic specifics of the constructions lies in the intersection of multidimensional featureplains, the degrees of: identifiability and topicality; agentivity; activeness/control/volition; completeness and affectedness.

ii) The "ergative" clause has Loc-marked agent referent and Ø-marked non-agent/target. Verbal morphology remains "active", demonstrating active-direct S/A-V and O-V agreement patterns, where applicable. Its functional-pragmatic motivation is representation of an event where the S/A referent, although fairly high on inherent agentivity and pragmatic identifiability, topicality (albeit parenthetical) is, however, low on activeness/control/authority status, merely mapping the locus of the event.

iii) The passive is a host of constructions unified by compatible general functional and structural specifications: identifiability, topicality of the non-agentive S referent. That is, these passive constructions prototypically exemplify the promotion of the non-agent referent to the $\mathrm{S}$ relation, and, in case of the agented passive, the demotion of the agent referent to a locative-marked non-S relation. It signals the deficit of authority/control and a shift in topicality, by altering the centrality of the referents in the proposition.

Actual functional specifics of the Eastern Khanty voice constructions lies in the intersection of multidimensional feature-plains: discourse pragmatic - the degrees of identifiability and topicality; semantic - activeness/control/volition and inherent agentivity; evidentiality - completeness, affectedness, reality.

Based on the above a notable continuity in the strategies of information structuring, i.e. consistency of association of certain morphosyntactic means with the set of pragmatic and semantic properties in the Eastern Khanty system is observed in the narrative discourse. The pragmatic features of identifiability, activation and topicality are consistently expressed by the grammatical features of verbal agreement, possessive/reflexive agreement, case marking, anaphora, ellipsis. The grammatical continuum NP-Prn.-Prn.Infl- $\varnothing$ is seen as iconic of the pragmatic continuum New Ref.Identif./Acces.-Active-Topical. Accidentally, this correlation of the pragmatic features and grammatical means is resonant with the posited ethymological make up/ the main grammaticalazation route: Prs.Prn.-Poss.Infl-Agreement.Infl.

Data Sample:

(i) Active-direct:

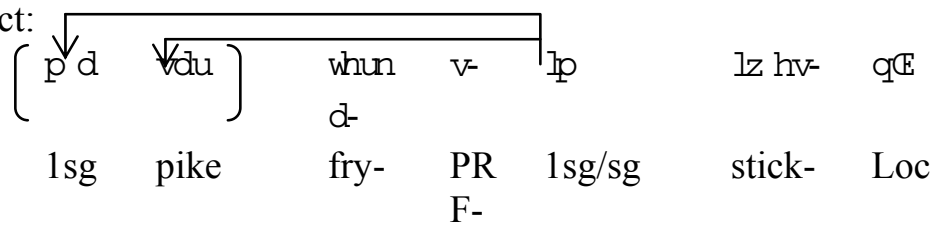

'(I) fried (the pike-fish) on sticks'

(ii) "Ergative":

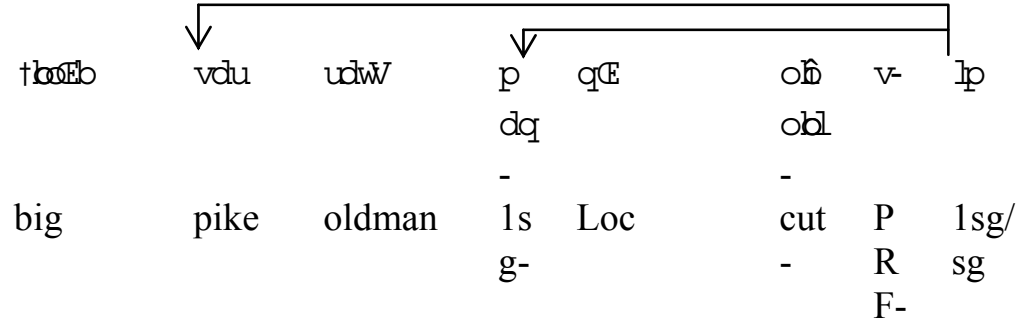

'I cut the big pike' 
(iii) Passive:

a) Agented

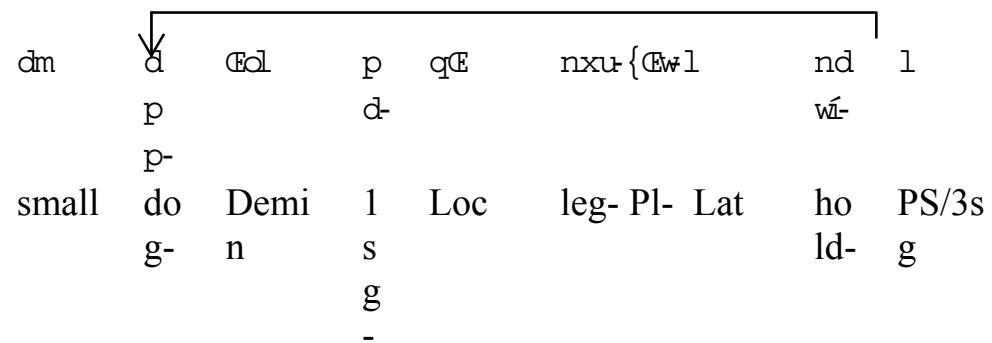

'I held the dog by the legs'

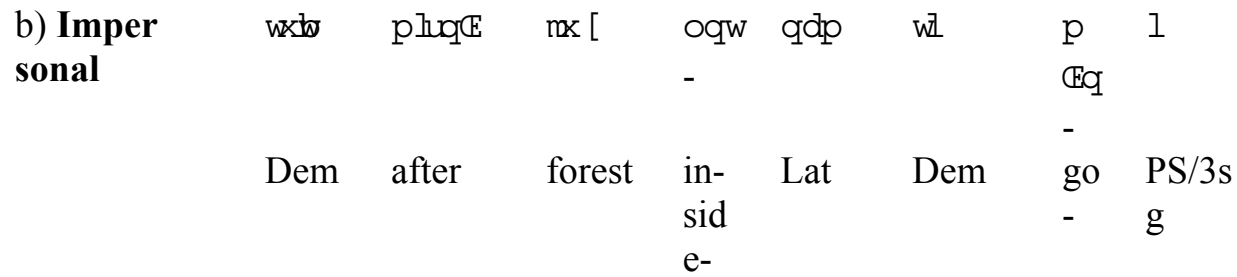

'After this (we) went to the woods'

Reflexivization:

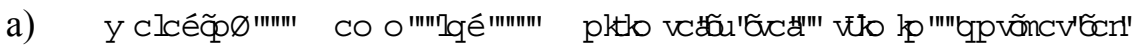
animal-Loc dog home pull-PRF-3sg there inside-house -3sg

'The bear hid the dog inside his (bear's / *dog's) house.'

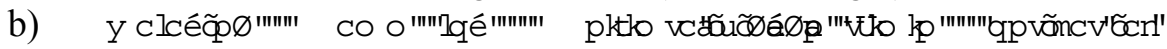
animal-Loc dog home pull-PRF-3sg/sg there inside-house-3sg

'The bear hid a dog inside his (bear's/dog's) house.'

O-V agreement:

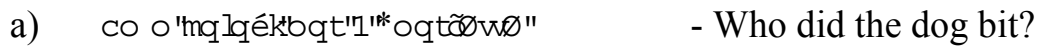

dog who bit.3sg

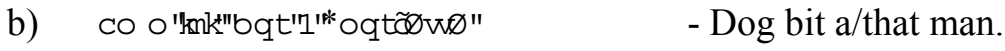
dog man bit.3sg /*3sg/sg

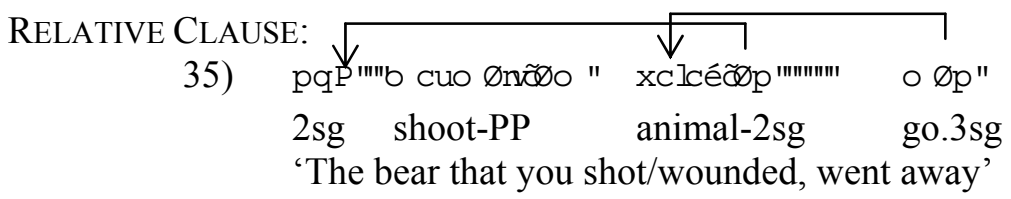

$2 \mathrm{sg}$ shoot-PP animal-2sg go.3sg

'The bear that you shot/wounded, went away'

\section{BIBLIOGRAPHY}

AiKHENVALD A.Y., DiXON R.M.W., Onishi M. 2001. Non-canonical marking of subjects and objects. Amsterdam/Philadelphia: John Benjamins.

BRESNAN, J., MCHOMBO, S. 1987. Topic, Pronoun, and agreement in Chichewa. Language 63, 74183.

BYBEE, J. 1985. Morphology: A Study of the Relation between Meaning and Form. John Benjamins.

COMRIE, B. 1975. Su and DO in Uralic languages.

COMRIE, BERNARD. 1978. Ergativity. In W. P. Lehman (ed.), Syntactic Typology. UT Austin Press.

DIXON, R.M.W. 1994. Ergativity. Cambridge: Cambridge University Press.

GIVON, T. 2001. Syntax. An Introduction. Amsterdam/Philadelphia: John Benjamins.

GulYA, J. 1966. Eastern Ostyak Chrestomathy. Bloomington: Indiana University Press.

Haspelmath, M. 1990. The Grammaticalization of Passive Morphology. Studies in Language 14, 1. $25-72$.

HOPPER, P. 1987. Emergent Grammar. BLS 13, 139-57. 
KeEnAN, E. 1985. Relative clause. In Shopen, T. (ed.): Syntactic Typology and Syntactic Description. Cambridge: Cambridge University Press.

Kovgan, E. 1991. Pricastno opredelitelnie konstruktsii v severnix dialektax xantiiskogo jazika. Dissertation. Novosibirsk.

KOSKAREVA, N. 1991.Konstruktsii s infinitivnimi formami glagola v xantiiskom jazike. Dissertation. Novosibirsk.

Kulonen, U-M. 1989. The Passive in Ob-Ugrian. Helsinki: The Finno-Ugrian Society.

LAMBRECHT, K. 1994. Information Structure and Sentence From. Cambridge: Cambridge University Press.

LANGACKER, R. 1993. Reference point constructions. Cognitive Linguistics 4, 1-38.

LEHMANN, C. 1984. Der Relativsatz: Typologie seiner Strukturen, Theorie seiner Funktionen, Kompemndium seiner Grammatik. Tuebingen: Gunter Narr Verlag.

NiKOLAEVA, I. 1999. Ostyak. Lincom Europa.

ONISHI, M. 2001. Non-canonical subjects and objects: Parameters and properties. In Aikhenvald, Dixon, Onishi (eds.), Non-canonical marking of subjects and objects. Amsterdam, John Benjamins.

ShiBATANI, M. 1985. Passives and Related Constructions. Language, 61: 4, 821-848. Subject and Topic. 1977. Ed. C. Li. London: Academic Press.

UBRJATOVA, E., Litvin, F. 1986. Strukturnie tipi sinteticeskix polipredikativnix konstruktsij v jazikax raznix sistem. Novosibirsk.

VAN VAlin, R., and LAPOLlA, R.J. 1997. Syntax. Structure, meaning, and function. Cambridge: CUP. 


\title{
TO THE TYPOLOGY OF ARGUMENT STRUCTURE IN THE IRANIAN LANGUAGES
}

\author{
KETEVAN GADILIA \\ The Institute for Bible translation, Moscow
}

The paper focuses on the typological study of argument structure within the group of related Iranian languages.

In the modern Iranian languages (both in the East-Iranian (EI) and the West-Iranian (WI) groups) several grammatical elements convey the meaning of the definiteness that is simultaneously used for distinguishing the direct and indirect objects.

As a result of analyzing the following rule became apparent that applies equally to several Iranian languages.

The direct object is obligatorily marked by the grammatical markers like the indirect case markers (WI and IE) and/or the particle $\boldsymbol{r} \hat{\boldsymbol{a}}$ (WI) 1These markers usually convey the meaning of definiteness.

(1) In the Iranian languages where the secondary innovation case paradigm was developed the particle -râ C radiy transformed in case markers (Balochi, Tati, Gilyani).

(2) In the languages where the old category of case was eliminated * radiy transformed in particle (postposition) and in this status became a part of the category definiteness that is closely tied with the category of case.

(3) Designation of definiteness is not the essential function of case markers. The agglutinative case paradigm was developed in Gilyani, Balochi and some other Modern Iranian languages, after reducing the Old Iranian multifunctional infletional case system. MI innovation agglutinative case category is not directly connected and correlated with the category of definiteness, but is deeply interrelated/interdependent. First, the direct case extends its sphere of usage to denote the direct and indirect objects. Afterwards the opposition of definite direct object vs. indefinite direct object became relevant. Thus, the definite nouns are marked by direct case markers as Balochi -râ and Gilyani $-\boldsymbol{a}$, while the indefinite nouns are represented by the nominative unmarked case. The purpose of designating actants by case markers is to distinguish the subject and the direct object of a transitive verb and avoid the possible polysemi. Thus case markers and the particle $-\boldsymbol{r} \hat{\boldsymbol{a}}$ in Modern Iranian languages reflect the topic - focus/subject - object relations. Marking actants is the result of changed sentence structure from Old Iranian SVO into Modern Iranian SOV. 


\title{
TEASING APART TELICITY AND GRAMMATICAL ASPECT
}

\author{
BERIT GEHRKE \\ University of Utrecht, Utrecht
}

In accordance with a number of researchers in the field (e.g. Smith (1991/97), Verkuyl (2003)), I will assume that aspectual-temporal information obtained at lower levels is not obscured by other such information obtained at higher levels. Rather, a compositional approach to aspectuality at higher levels is pursued as the meaning gets more complex with different possible meaning effects due to different layers of meaning that in a way get 'piled on top of each other'. Although it is widely acknowledged that Aspect and telicity are two different notions (e.g. Glasbey (1998), Borik (2002)), there have been some suggestions for defining Aspect in terms of telicity (e.g. Verkuyl (1972)). This strategy is especially prominent for Slavic (e.g. Filip (1993/99) or van Hout (2003)) due to a dynamic interaction of both categories. Nevertheless, it is crucial for a compositional approach to define Slavic Aspects in a way that is not influenced by certain telicity effects, which is a problem for many theories on this topic (e.g. Filip (1993/99) or Borik (2002)).

By taking telicity as a strictly semantic notion, be it in terms of quantizedness (Filip) or subinterval property (Borik), eventualities described by verbs, predicates, and even complex sentences are classified as telic or atelic at one point or another. In this way, telicity turns out to be equivalent to the notion of 'boundedness' that can be applied to various language levels as well. Both concepts are too vague and not very useful in a compositional approach to aspectuality in general. I will assume instead that (a)telicity is a structural property and an instance of inner aspectuality and thus a property of VPs, only. ${ }^{1}$ The particular telicity property of a predicate remains stable throughout the derivation and the eventuality type can be unbounded and bounded at higher levels by different means, belonging to the realm of outer aspectuality, which also includes grammatical Aspects.

There is evidence for a structural as well as semantic asymmetry in the pattern of Slavic prefixes. Di Sciullo \& Slabakova (forthcoming) address this problem and state that only internal prefixes may change the telicity of the event denoted by the verbal projection they are part of. For Bulgarian they claim that internal aspectual features are part of the v projection whereas external aspectual features are part of the Tense projection. This is supported by certain properties of Bulgarian prefixes:

1. An external prefix must precede an internal one, whereas the reverse order is ungrammatical.

2. External prefixes do not alter the "Aktionsart" of the verb, while internal prefixes do so, since they signal telicity.

3. When more than one prefix occurs on a given stem, it is only one of them that supplies the endpoint of the event, the others offer additional meanings similar to adverbial modification.

A similar distinction between two groups of Slavic prefixes (lexical vs. superlexical) is also found in Svenonius (forthcoming) and Romanova (forthcoming) for Russian, and Milićević (2003) for SerboCroatian. The conclusion of these three authors is different from the one drawn in this paper, though. I will claim that in Slavic languages, internal prefixes that apply to verbs (i.e. lexical items) and participate in their argument structure grammaticalize telicity rather than Aspect, whereas only external prefixes belong to the realm of outer aspectuality, applying higher in the tree to (telic or atelic) predicates (VPs) without changing the telicity property of the predicate they apply to.

First, I will show that the three properties mentioned above also hold for Russian and Czech prefixes. This can be illustrated by means of the highly productive external prefix po- supplying the meaning 'a bit' and attaching to atelic or telic predicates without changing their telicity value. In Russian, the external prefix po- marks Perfectivity on atelic VPs or otherwise temporally unbounded eventuality descriptions (delimitative Aktionsart). It gets a temporal interpretation only ('for a while'):

\footnotetext{
${ }^{1}$ At this point, I can only give an informal definition for telic predicate types as denoting some point of change.
} 
(1) On po-sidel. - 'He sat / was sitting (for a while).'

On po-ležal. - 'He lay / was lying (for a while).' (Russian)

A piece of supporting evidence for the claim that the VP remains atelic can be seen in the interaction with temporal adverbials, since such Perfective verbs are only compatible with durational adverbials but not with frame adverbials (2), whereas it is the other way round with verbs containing internal prefixes marking telicity (3):
On popisal
dva časa / *za dva časa. (Russian)
he-NOM PO-write-PAST two hours in two hours
'He was writing for two hours / *in two hours.'

On napisal pis'mo *dva časa / za dva časa. (Russian)
he-NOM PF-write-PAST letter two hours in two hours
'He wrote a / the (whole) letter for two hours / in two hours.'

The claim that such external prefixes attach at a higher level to the whole VP without changing its telicity value is further supported by the fact that they cannot occur as infinitival subjects. In the dictionaries, one does not find independent lexical entries of these verbs and infinitives are always dependent on some other verbal form, e.g. Nado pogovorit's nim. - 'It is necessary to (have a) talk with him.' Russian $p o$ - thus functions as a temporal delimiter, comparable to for-adverbials, and provides the interpretation of temporal boundedness at sentence and discourse level. The verb becomes Perfective but the VP itself stays atelic, since there is no additional change in argument structure and no telicity effect.

In Czech, on the other hand, the external prefix po- hardly ever conveys a temporal but rather a spatial interpretation (cf. Filip (forthcoming)). In most cases, it is combined with Perfective telic verbs and functions like a weak quantifier, e.g.:

(4) Pak holička po-odstoupila [...] (Kundera, Žert) (Czech)

then hairdresser-NOM PO-PF-from-step-PAST

'Then the hairdresser stepped aside a little.'

This spatial meaning cannot be rendered by the Russian cognate but an additional lexical item čut' 'a bit' is used instead:

$$
\begin{aligned}
& \text { Potom parikmaxeř̌a otošla čut' [...] (Russian) } \\
& \text { then hairdresser-NOM PF-from-go-PAST bit }
\end{aligned}
$$

In general, Russian external prefixes mark temporal boundaries, only, whereas in Czech, these boundaries primarily get a spatial interpretation. Russian and Czech and presumably other Slavic languages differ primarily with respect to the usage of external prefixes. The usage of internal prefixes and thus the marking of telicity on the verb is more or less identical in both languages. I will take this as supporting the claim about the asymmetry of Slavic prefixes. ${ }^{2}$

In addition to marking telicity on a simple verb, most Slavic internal (or lexical) prefixes derive new lexical items, often accompanied by a change in argument structure. From these new lexical items Slavic languages regularly derive secondary Imperfectives by means of suffixes, mainly, which never change the argument structure or the lexical meaning of the base verb but only its Aspect. Hence, secondary Imperfectives should be considered telic as well, since they contain internal prefixes. They still imply a natural point of change, the existence of which is stripped off by the suffix. ${ }^{3}$

\footnotetext{
${ }^{2}$ As to Di Sciullo \& Slabakova's first point, the Russian po-vy-daval 'gave out for a while' and the Czech pood-stoupil 'stepped aside a bit' are used instead of the ungrammatical *vy-po-daval and *od-po-stoupil.

${ }^{3}$ A similar effect of the combination of telicity and Imperfectivity arises when the English Progressive is combined with a telic VP (cf. Moens \& Steedman (1988)) . Its semantic effect is not exactly the same, though, because English has an overt marking of Imperfectivity but neither of telicity nor Perfectivity.
} 
In this case the suffix explicitly marks that the natural point of change of the eventuality type described by the prefixed verb has not been reached in the actual case. ${ }^{4}$

Finally, it has been noted that the quantizedness property of the internal argument (in the sense of Krifka (1992)) is not in all cases decisive for the predicate being telic. Ramchand (forthcoming), for example, convincingly argues that this is only the case with one class of verbs, namely verbs of creation and consumption which combine with incremental theme arguments (undergoers). Such observations, which stand in sharp contrasts to theories simply deducing the telicity value of a predicate from the properties of the internal argument (e.g. Verkuyl), seem to be reflected in the morphological processes found with Slavic verbs and the forming of aspectual pairs: Typically we find aspectual pairs with so-called empty prefixes precisely where the quantizedness properties of the internal argument is decisive for the telicity value of the VP. The whole VP is either telic when combined with a quantized incremental theme argument or atelic in combination with a cumulative incremental theme argument, resulting in a homomorphic mapping from the domain of objects to the domain of events (cf. Krifka (1992)). This is in accordance with Filip (1993/99) for Czech and Di Sciullo \& Slabakova (forthcoming) for Bulgarian. Telic verbs, on the other hand, i.e. those with internal prefixes, form aspectual pairs with secondary Imperfectives. Finally, atelic verbs stay imperfectiva tantum but can be perfectivized by external prefixes deriving what is traditionally known as Perfective Aktionsart verbs. Hence, Slavic verbs can be divided into strictly atelic verbs, strictly telic verbs and verbs that can give rise to either a telic or an atelic interpretation.

The observations made so far have impact on the question of markedness of Aspect. Traditionally, it is claimed that the Slavic Imperfective Aspect is (semantically) unmarked with respect to the Perfective Aspect and that both constitute a privative or even subordinative opposition (see also Borik (2002), Klimonow (2000)). It has also been noted that this is not always in accordance with the morphological marking so that in some cases the morphological marking is claimed to be contraiconic (e.g. Klimonow). Bohnemeyer \& Swift (forthcoming) address the issue of Aspect and markedness from a quite different angle than what is usually done in the Slavistic tradition. They define grammatical Aspect as viewpoint aspect and constitute a telicity bias in viewpoint selection with some languages, where there are marked Imperfective Aspect and unmarked Perfective Aspect for telic predicates but just the opposite distribution for atelic predicates (e.g. Russian, Yukatek Maya). Such a telicity bias is also found in Early Child Language: In English, for example, there is a preference for using the ing-form with atelic predicates, and the $e d$-form with telic ones. This bias is directly reflected in Russian Aspect marking which depends on the telicity of the predicate. ${ }^{5}$

To account for the morphological differences between Imperfective simple verbs and secondary Imperfectives and with the distinction between telicity and Aspect worked out so far, I conclude that the Imperfective Aspect is not unmarked per se, but that there are different levels of morphological markedness, resulting in different kinds of semantic markedness. ${ }^{6}$ In particular, there is a privative opposition of unmarked atelicity vs. marked telicity interacting with the equipollent opposition Imperfectivity vs. Perfectivity.?

\footnotetext{
${ }^{4}$ This can give rise to different interpretations, e.g. a process meaning: it has not been reached yet, or any meaning of repetition: the whole macro-event (process of the macro-event) has not come to an end, but its micro-events might have reached their particular points of change.
}

${ }^{5}$ Slavic atelic predicates are unmarked for Imperfectivity and marked for Perfectivity by prefixes on the verb, whereas telic ones are unmarked for Perfectivity and marked for Imperfectivity (so-called secondary Imperfectives) by verbal suffixes (productive), less often vowel alternation (not productive).

${ }^{6}$ Empirical research (Gehrke (2002)) shows that this is reflected in the usage of Czech and Russian aspectual affixes. It also shows that grammatical aspect cannot be relegated to one particular level, but fulfils different functions at different levels. In Russian, temporal boundedness at sentence level can be marked by perfectivizing prefixes on atelic predicates, whereas temporal unboundedness at discourse level (habituality) is marked by imperfectivizing suffixes. In Czech, on the other hand, Aspect does not operate on these higher levels in such a way and temporal (un)boundedness is generally marked by other lexical means or contextually induced.

${ }^{7}$ Each affix has some specific meaning effect, which is not necessarily grammatical aspect alone. If there were only one imperfective and one perfective meaning each and every affix were used solely to express just one out 


\section{REFERENCES}

BOHNEMEYER, J., and M. SWIFT (forthcoming). Default Aspect: The Semantic Interaction of Aspectual Viewpoint and Telicity. To appear in To appear in van Hout, A., H. de Swart, and H.J. Verkuyl (eds.), Perspectives on Aspect. Dordrecht: Kluwer.

BORIK, O. 2002. Aspect and Reference time. Doctoral dissertation. Utrecht: Utrecht Institute of Linguistics OTS.

Di SciUllo, A.M., and R. SlabaKova (forthcoming). Quantification and Aspect. To appear in van Hout, A., H. de Swart, and H.J. Verkuyl (eds.), Perspectives on Aspect. Dordrecht: Kluwer.

FILIP, H. 1993/1999. Aspect, Eventuality Types and Nominal Reference. New York: Garland Publications.

FILIP, H. Forthcoming. On Accumulating and Having it All. To appear in van Hout, A., H. de Swart and H.J. Verkuyl (eds.), Perspectives on Aspect. Dordrecht: Kluwer.

GEHRKE, B. 2002. Systemhafte Unterschiede im Aspektgebrauch zwischen dem Russischen und dem Tschechischen. Magisterarbeit, Institut für Slawistik, Humboldt-Universität Berlin.

Glasbey, S. 1998. Progressives, States and Backgrounding. In Rothstein, S. (ed.), Events and Grammar, 105-124. Dordrecht: Kluwer.

VAN HOUT, A. 2003. Acquiring telicity crosslinguistically: On the acquisition of telicity entailments associated with transitivity. In Bowerman, M. and P. Brown (eds.), Crosslinguistic perspectives on argument structure: Implications for learnability. Hillsdale: Lawrence Erlbaum.

KLIMONOW, W. 2000. Ikonismus und Abweichungen vom Ikonismus in grammatischen Kategorien. Prace Filologiczne XLV, 277-290.

KRIFKA, M. 1992. Thematic Relations as Links between Nominal Reference and Temporal Constitution. In Sag, I. A., and Szabolcsi, A. (eds.), Lexical Matters, 29-53. Stanford: CSLI Publications.

MiLIĆEviĆ, N. 2003. The lexical and superlexical prefix $i z$ - and its role in the stacking of preifxs. Ms. University of Tromsø and University of Novi Sad.

Moens, M., and M. STEEDMAN. 1988. Temporal Ontology and Temporal Reference. Computational Linguistics 14:2, 15-28.

RAMChand, G. Forthcoming. Aktionsart, L-syntax and Selection. To appear in van Hout, A., H. de Swart \& H.J. Verkuyl (eds.), Perspectives on Aspect. Dordrecht: Kluwer.

Romanova, E. (forthcoming). Superlexical vs. Lexical prefixes. In P. Svenonius (ed.), Working Papers on Slavic Prefixes. University of Tromsø.

SMITH, C. S. 1991/1997. The Parameter of Aspect. Dordrecht: Kluwer.

SVENONIUS, P. Forthcoming. Introduction in P. Svenonius (ed.), Working Papers on Slavic Prefixes. University of Tromsø.

VERKUYL, H. J. 1972. On the Compositional Nature of the Aspects. Reidel: Dordrecht.

VERKUYL, H. J. 2003. How (in-)sensitive is tense to aspectual information? Unpublished paper, Utrecht University.

of these two meanings, one would not expect to find verbs with more than one affix at a time (as in some of the given examples). Thus, at least some of them clearly must have a different purpose if they can co-occur. 


\title{
COMPLEMENTATION AND CONTROL IN ADYGHE
}

\author{
DMITRY GERASIMOV \\ Institute for Linguistic Research, St. Petersburg
}

Adyghe (Circassian, Northwest Caucasian) possesses a rich system of non-finite verbal forms used to code sentential complements. Traditional grammar divides this set of forms into a number of categories under the standard labels such as "masdar", "participle", "converb", etc. It can easily be shown however, that morphologically all these non-finite forms fit into a single paradigm, being able to attach both Case and TAM-markers at the same time. Thus, the segment -new, traditionally referred to as "supine ending" is clearly analyzable as a combination of the Future Tense marker - $n$ - and the Adverbial Case marker -ew. No special transcategorial morphemes are used to indicate the non-finite status of complement verbs, save for the zere- prefix that marks complements of factive predicates. So, in general the morphological structure of the (intransitive) complement verb corresponds to the following scheme: (Pers) + (-zere-) + Stem + (Case) + (TAM). Contrary to [Noonan 1985]'s assumption, Adyghe seems to lack the sentential-like strategy of complementation, except conditional and concessive forms used in "if-clause" complements. There are some peripheral cases when complement predicates do not inflect for Case (in Adyghe only nouns with defined reference take overt Case markers, the same mutatis mutandis applies to sentential complements), and so their finite/non-finite status is somewhat problematic. Such cases will be treated in more detail at the presentation.

The co-occurrence of TAM markers with Case endings (the latter being assigned by the matrix predicate) is especially interesting, if we take into account that basic inflectional categories in Adyghe, such as Case and TAM, are oriented to sentential functions (such as argument and predicate) rather than to parts of speech (such as noun and verb). Thus, a TAM marker can be easily attached to a NP used in the predicate position.

With respect to co-reference relations, Adyghe shows a great variability: both Subject and Object "Control" can be Forward or Backward. It is notable that one and the same predicate can participate in Forward and Backward "Control". It is not clear what actually determines the choice between forward and backward strategies; since in both types of constructions there are cases when the reference of the silent participant can't be identified unambiguously, it may depend on whether the speaker considers the situational semantics of the higher or the lower predication more important.

It is still not quite clear whether Adyghean complements are syntactically true complements and not complement-like adverbial clauses (hence we take the word "Control" in quotes). If they are, than the pattern described in the preceding passage will be of great value for the typology of control structures. Anyway, the syntactic relation between matrix and embedded predication and, therefore, the nature of the silent argument remains problematic. Further investigation concerning selectional restrictions, behaviour of negative markers and various modifiers is required to give a final answer to the question. Some evidence pro and contra will be presented in the paper. 


\title{
CROSS-LINGUISTIC VARIATION IN OVERALL EXPRESSIVE POWER
}

\author{
DAVID GIL \\ Max Planck Institute for Evolutionary Anthropology, \\ Department of Linguistics, Leipzig
}

While many linguists believe that semantic structures are universal, it is sometimes recognized that languages may differ with respect to their expressive power: their ability to express concepts of various kinds. Nevertheless, the study of cross-linguistic variation in expressive power is often predicated on the assumption that such differences "make up for each other", and that if one language happens to be of lesser expressive power than another with respect to one semantic domain, it will be of greater expressive power with respect to some other semantic domain. In other words, it is generally assumed that if, somehow, for each language, one could calculate the total expressive power across all semantic domains, all languages would come out to be roughly the same.

This paper argues that the assumption of equal overall expressive power is false. Instead, it is claimed that languages may and actually do differ significantly with respect to their total expressive power. Two lines of argumentation are presented: a principled argument suggesting that languages may and in fact must differ with respect to overall expressive power, and an empirical argument showing that languages actually do so differ.

On a theoretical level, it is actually very hard to envisage the kind of regulatory mechanism that would be necessary in order to ensure equal overall expressive power. Whatever the differences between them, most or all theories of language or of grammar are endowed with an architecture that is essentially modular, distinguishing between different grammatical and semantic domains that are subject to different kinds of rules and principles. To cite just one obvious example, it is hard to imagine a theory that did not distinguish between two phenomenological domains corresponding to what is commonly referred to as "argument structure" and "tense/aspect". (Note: the assumption of modularity does not preclude that such modules may interact, such as, for example, when verbal aspect affects the choice of an accusative or absolutive case-marking system; what it says is simply that the relevant modules are themselves of very different nature.) Now in order to maintain equal total expressive power, there would have to exist some overall regulatory mechanism that would be able to interact with just about every nook and cranny of the grammar, adding up the expressive power of each module, in order to ensure that the sum total reaches the pre-ordained universal target value. Such a mechanism is, to say the least, highly implausible. And it gets worse. What happens if a language develops a new semantic distinction in some particular domain, say an elaboration of the tense/aspect system? In order to maintain equal overall expressive power, the regulatory mechanism would have to compensate for this new distinction by reducing expressive power in some other module of grammar, perhaps by getting rid of some spatial distinctions expressible by means of case markings. But language simply does not work in this super-holistic way. Thus, it is hard to imagine the existence of a regulatory mechanism of the kind required by the assumption of equal overall expressive power. Moreover, in the absence of such a mechanism, it is extremely unlikely that the overall expressive power of all languages would, by sheer accident, end up roughly the same. Rather, it is a statistical near-certainty that the diverse diachronic processes governing the ways languages change over time would yield cross-linguistic variation in overall expressive power. Indeed, one would expect such variation to be of the kind characterizable by a bell-shaped curve, with a large number of languages with more or less average overall expressive power, sandwiched between a smaller number of outlying languages with significantly greater than average, or lesser than average, overall expressive power.

Empirical support for cross-linguistic variation in overall expressive power may be obtained from various psycholinguistic experiments designed to measure the expressive power of different languages. This work is still in preliminary stages, and therefore conclusive results are not yet available. However, interim results provide prima facie support for the existence of significant variation in overall expressive power. One experiment measures a global parameter which might be referred to as the specificity of a language. The experiment consists of two stages. At Stage 1, subjects are presented with pictures of various events, and are asked to construct a one-sentence description of each 
picture. At Stage 2, a different set of subjects are presented with the one-sentence descriptions obtained before, and, for each such sentence, with a set of 20 pictures: one of these pictures is the original picture for which the description was provided, while the remaining 19 pictures each differ from the original picture with respect to exactly one semantic feature, chosen from a set that includes number, gender, spatial orientation, colour, shape, thematic role, aspect, and many others. For each sentence, subjects are asked to identify which of the 20 pictures are appropriately described by the given sentence. This number provides a measure of the overall specificity of the language: the fewer pictures that are chosen, the greater the overall level of specificity of the language. Work on this experiment is still in progress. A second experiment, similar in goal but of a more restricted nature, pertains specifically to thematic roles, measuring the specificity of languages in this particular domain. Preliminary results now becoming available for English, Hebrew, and several languages spoken in Indonesia suggest that with respect to thematic roles, English and Hebrew are characterized by a greater degree of specificity than their counterparts in Indonesia. Differences with respect to specificity thus constitute one of the ways in which languages may differ with respect to expressive power. Work in progress within this experimental paradigm is leading towards the conclusion that languages may indeed differ with respect to their overall expressive power. 


\title{
ON ARGUMENT STRUCTURE IN TATAR AND FINNISH CONVERB CLAUSES
}

\author{
TEIJA GREED \\ Summer Institute for Linguistics (SIL)
}

The present paper deals with the argument structure of Tatar and Finnish converb clauses from a typological perspective. These two languages have been chosen due to the many structural and typological similarities that appear to exist between them. The purpose of the research is twofold: firstly to find out how the argument structure - in our case the subject and object - in Tatar and Finnish converb clauses compares with that of the basic finite clause/sentence; and secondly to compare and contrast the arguments in Tatar and Finnish converb clauses.

Tatar and Finnish belong to different language families - Tatar to the Altaic, and Finnish to the Uralic language family. However, typologically there are many similarities between them. Morphologically they are both agglutinative, and strongly suffixing languages, and in genitive constructions both can mark the head as well as the dependent. Syntactically both are pro-drop languages, and both use non-finite verb forms, such as converbs and participles, extensively.

This paper focuses on the converb, that is, a non-finite verb form that functions as a free adverbial modifying the finite verb or the entire main clause. An example from Finnish is given in (1), and a Tatar example in (2).

$$
\begin{aligned}
& \text { fall.over-CONV(2INF.INE)-POSS.3s Maija hurt-PST.3s leg-ACC+POSS } \\
& \text { 'When falling over, Maija hurt her leg.' } \\
& \text { Janggyr bet-kach, bala uram-ga chyq-ty. } \\
& \text { rain finish-CONV child street-DAT go.out-PST.3s } \\
& \text { 'After it had stopped raining, the child went out.' }
\end{aligned}
$$

In (1) the converb, kaatuessaan, modifies the finite verb satutti. In (2) the converb betkach (with its argument) modifies the main clause. In Tatar and Finnish, converbs are typically used in syntactically subordinate clauses.

Converb clauses in both Tatar and Finnish can frequently take subjects and objects. Special attention is given to describing the possibilities and limitations for converb clause arguments. For example, in Finnish, different rules apply to different types of converbs, whereas in Tatar there are fewer restrictions.

In both Tatar and Finnish, the object in converb clauses retains the form it would have had in the equivalent basic finite clause. An object which is in a main clause occurring with a converb clause sometimes undergoes changes, depending on whether it is co-referent with the subject or the object of the converb clause. The purpose of these changes is to make the reference explicitly clear.

While the changes affecting the object are relatively constrained, the subject in both languages experiences greater changes when it occurs in a converb clause. In many cases the way the subject is marked in converb clauses is different from the way it is marked in finite clauses. These differences depend on many factors, one of the most important being whether the subjects of the converb clause and main clause are co-referential. The general principle is towards economy: if the subjects are coreferential, the subject is made explicit with a noun phrase only in one of the clauses. This is particularly prevalent in Tatar.

The subject of the converb clause can be non-co-referential with the subject of the main clause in both Tatar and Finnish. However, Tatar is far freer: almost all the converbs are able to take non-coreferential subjects. Finnish is more restricted: some converbs do not allow for non-co-referential subjects at all, while certain others allow them only very rarely.

The subject of converbs takes various forms: an independent noun phrase, a possessive suffix, agreement marking on the main verb, or zero. The principles determining what form a subject will take are different in Tatar and Finnish. In discourse Tatar, unlike Finnish, also allows the subject to be fully implicit in both the converb clause and the main clause, if the subject is evident from the preceding context.

The argument structure in Tatar and Finnish converb constructions has key similarities, largely in the broad spectrum, but numerous differences, mainly in the details. 


\title{
ON MISMATCHES BETWEEN SYNTAX AND MORPHOLOGY IN GEORGIAN
}

\author{
OLYA GUREVICH \\ University of California, Berkeley
}

Georgian presents a clear case of mismatch between syntactic argument structure and morphological agreement. The mismatches include the relation between pronominal agreement and case marking, number agreement, and the number of slots in the syntactic and morphological frames. These mismatches are typologically unusual yet very systematic in the language. They tend to weaken the status of grammatical relations, to the point where some scholars have proposed that the notions of subject and object are not relevant for Georgian at all. In this paper, I will explore the mismatches between morphosyntactic agreement and grammatical relations in Georgian. I will argue that morphosyntactic agreement and grammatical relations, while representing orthogonal sets of distinctions, must nevertheless be represented within the same frameworks in order to account for language acquisition and use. I will propose such a representation within the framework of Construction Grammar [Kay and Fillmore 1999, Goldberg 1995].

The biggest issue is that grammatical relations are expressed differently by case marking and pronominal agreement. The Georgian verbs are traditionally divided into four conjugation types based on semantic and syntactic criteria, as follows [Aronson 1990, Holisky 1981].

- Conjugation I - Transitive Verbs

- Conjugation II - Intransitive verbs derived from Conj I verbs

- Conjugation III - Intransitive active verbs (medial verbs)

- Conjugation IV - Indirect verbs

Each verb can be conjugated in several tenses, or screeves. The screeves can be grouped into three Series based on commonalities in case marking, agreement, and morphological formation patterns. There are three possible case marking patterns, as in 0.

(0) Case-marking patterns

\begin{tabular}{|c|c|c|c|}
\hline Pattern & Subject & Direct Object & Indirect Object \\
\hline A & NOM & DAT & DAT \\
B & ERG & NOM & DAT \\
C & DAT & NOM & postposition phrase \\
\hline
\end{tabular}

Pattern C has also been called the Inverted pattern. Tuite [1994] has argued that the DAT argument in the Inverted pattern is still the syntactic subject.

The verbs of four conjugation types choose the following patterns in the three Series:

(1) Case-marking patterns by conjugation type and Series

\begin{tabular}{|c|c|c|c|c|}
\hline & Conjugation I & Conjugation II & Conjugation III & Conjugation IV \\
\hline Series I & $\mathrm{A}$ & $\mathrm{A}$ & $\mathrm{A}$ & $\mathrm{C}$ \\
Series II & $\mathrm{B}$ & $\mathrm{A}$ & $\mathrm{B}$ & $\mathrm{C}$ \\
Series III & $\mathrm{C}$ & $\mathrm{A}$ & $\mathrm{C}$ & $\mathrm{C}$ \\
\hline
\end{tabular}

The most obvious issue with these patterns is that the subject and object are not represented consistently by the same case, and even different verb types can have different subject and object case marking.

Pronominal agreement on the verbs follows somewhat different principles. The verb marks agreement with the subject, object, and sometimes the indirect object. Subject and object agreement is expressed by a combination of prefixal and suffixal markers. Traditionally, two sets of agreement markers have been identified. The alternation indicated below is conditioned by phonology, screeve, and verb type. 


\begin{tabular}{|c|c|c|c|}
\hline \multicolumn{4}{|c|}{ v-Set: } \\
\hline & Singular & & \\
\hline 1 & $\mathrm{~V}-$ & V- & $-t$ \\
\hline 2 & - & - & $-t$ \\
\hline 3 & $-s /-a /-o$ & & 1/es/nen \\
\hline
\end{tabular}

\begin{tabular}{|c|c|c|}
\hline \multicolumn{3}{|c|}{ m-Set: } \\
\hline & Singular & Plural \\
\hline 1 & $\mathrm{~m}-$ & gv- \\
\hline 2 & g- & g- \\
\hline 3 & $-/ \mathrm{h} / \mathrm{s}$ & $-/ \mathrm{h} / \mathrm{s}$ \\
\hline
\end{tabular}

Both sets can mark subject or object agreement in different circumstances. Indirect object agreement can be (optionally) marked by a pre-stem vowel, or not marked at all. The choice of agreement by Series and Screeves is as follows:

(3) Pronominal agreement patterns by conjugation type and Series

\begin{tabular}{|c|c|c|c|c|c|c|c|c|c|c|c|c|}
\hline & \multicolumn{4}{|c|}{ Conjugation I } & \multicolumn{4}{c|}{ Conjugation II } & \multicolumn{3}{c|}{ Conjugation III } & \multicolumn{3}{c|}{ Conjugation IV } \\
\hline Argument & S & O & IO & S & O & IO & S & O & IO & S & O & IO \\
\hline Series I & $\mathrm{v}$ & $\mathrm{m}$ & $\mathrm{yes}$ & $\mathrm{v}$ & $\mathrm{m}$ & $\mathrm{no}$ & $\mathrm{v}$ & $\mathrm{m}$ & $\mathrm{yes}$ & $\mathrm{m}$ & $\mathrm{v}$ & no \\
Series II & $\mathrm{v}$ & $\mathrm{m}$ & $\mathrm{yes}$ & $\mathrm{v}$ & $\mathrm{m}$ & $\mathrm{no}$ & $\mathrm{v}$ & $\mathrm{m}$ & $\mathrm{yes}$ & $\mathrm{m}$ & $\mathrm{v}$ & no \\
Series III & $\mathrm{m}$ & $\mathrm{v}$ & $\mathrm{no}$ & $\mathrm{v}$ & $\mathrm{m}$ & $\mathrm{no}$ & $\mathrm{m}$ & $\mathrm{v}$ & no & $\mathrm{m}$ & $\mathrm{v}$ & no \\
\hline
\end{tabular}

The first mismatch which can be seen by comparing tables 0 and 0 is that the choice of pronominal agreement set is not always correlated with the case of the nominal argument. Set $v$ markers correspond to NOM in Series I but to ERG in Series II. Set $m$ markers correspond to DAT in Series I but to NOM in Series II. The situation is even more complex in Series III. While in Series I and II, the marker sets were consistently associated with subject and object, in Series III this relationship is flipped for several verb types: Set $v$ markers correspond to subjects in Series I and II but to objects in Series III; and Set $m$ markers correspond to objects in Series I and II but to subjects in Series III. This seems inconsistent: in Series I and II, there was not firm association between agreement marker set and nominal case, but in Series III the agreement markers invert when the cases do.

Another mismatch concerns the indirect object agreement. In the syntactic argument structure, the IO is not a core argument only in cases where case-marking pattern $\mathrm{C}$ is followed. In the morphology, IO agreement is impossible whenever the case-marking pattern is $\mathrm{C}$, but also in other situations (marked by 'no' in the preceding table).

The next mismatch concerns the number of slots in agreement paradigms. Nouns always inflect for case and number, but plural agreement on the verbs is more complex. A non-inverted agreement paradigm (in Series I) is in 0

(4) Non-inverted agreement paradigm, Series I

\begin{tabular}{|c|c|c|c|c|c|c|c|c|c|c|}
\hline \multirow{3}{*}{$\begin{array}{c}\text { SUBJ } \\
1 S G\end{array}$} & \multicolumn{10}{|c|}{ OBJECT } \\
\hline & \multicolumn{2}{|c|}{ 1SG } & \multicolumn{2}{|c|}{ 1PL } & \multicolumn{2}{|c|}{ 2SG } & \multicolumn{2}{|c|}{ 2PL } & \multicolumn{2}{|c|}{3} \\
\hline & & & & & $g$ & & g & $\mathbf{t}$ & $\mathbf{v}_{-}$ & \\
\hline 1PL & & & & & g & $\mathbf{t}$ & g & t & $\mathbf{v}_{-}$ & $\mathbf{t}$ \\
\hline 2SG & $\mathbf{m}$ & & gv & & & & & & & - \\
\hline 2PL & $\mathbf{m}$ & $t$ & & $\mathbf{t}$ & & & & & & t \\
\hline 3SG & m & $\mathbf{s}$ & $\mathbf{g v}$ & $\mathbf{S}$ & $\mathbf{g}$ & $\mathbf{S}$ & g & $\mathbf{t}$ & & $\mathbf{s}$ \\
\hline 3PL & $\mathbf{m}$ & en & gv & en & g & en & g & en & & en \\
\hline
\end{tabular}

Note that there is no explicit agreement with $3 \mathrm{Pl}$ objects. By contrast, an inverted paradigm is presented in 0 . 
(5) Inverted agreement paradigm:

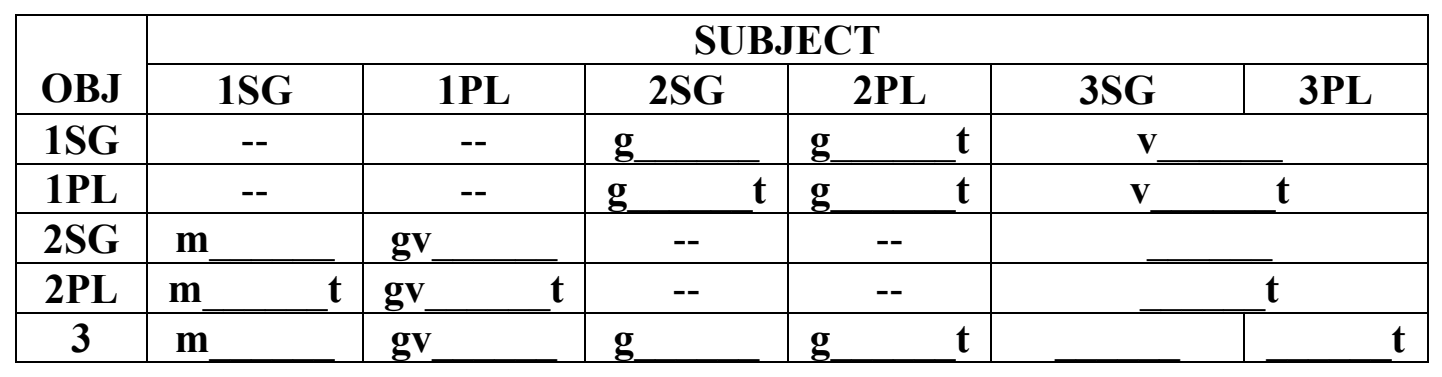

The inverted paradigm looks almost identical to the non-inverted paradigm with subject and object reversed, except that it contains fewer cells: the inverted paradigm distinguishes plural subjects only when the object is $3^{\text {rd }}$ person. There is no parallel to this difference in inverted vs. non-inverted syntactic patterns.

Thus is seems that there are two types of parameters through which a sentence can express event participants. One is through case marking on the nominal arguments, which is sensitive to verb type and screeve. Another is through verbal agreement, which is also sensitive to verb type and screeve, but subdivides the space of possibilities in a different way.

One prominent generalization is that the verbal agreement markers preserve a permanent association with person/number qualities, in particular for $1^{\text {st }}$ and $2^{\text {nd }}$ person arguments. Thus, the marker $m$ - always corresponds to a $1 \mathrm{Sg}$ argument, be it subject or object, and the marker $g v$-always corresponds to a $1 \mathrm{Pl}$ argument.

Traditionally, the case marking patterns in 0 are said to apply to arguments in all person/number combinations. However, $1^{\text {st }}$ and $2^{\text {nd }}$ person pronouns in Georgian do not inflect for case. Thus, case marking for those types of arguments is not helpful for deciphering subject / object relations, although verbal agreement is. So, in a sense, verbal agreement identifies conversation participants while nominal case marking identifies formal grammatical relations.

In summary, the Georgian verbal morphology and syntactic argument structure are mismatched in important and regular ways. This has led some analysts to propose separate levels of syntactic and morphological structure [e.g. Anderson 1992]. The morphosyntactic properties are passed down from syntax to morphology, and in morphology they undergo a series of fusion and fission rules in order to match the available agreement markers. Thus, there is an abstract level between syntax and morphology where the mismatches can be fixed.

However, even if argument structure and verbal agreement exist on separate levels, they still have to interact and be acquired by language learners. Recent studies in language acquisition have emphasized that learning proceeds as an item-based, very concrete process where learners extract generalizations based on specific words they know, and not on abstract level ordering [Tomasello 2003]. How can we represent the mismatched syntactic and morphological patterns in a way compatible with language acquisition?

I propose a representation within the framework of Construction Grammar [Kay and Fillmore 1999, Goldberg 1995] which argues for the existence of constructions as grammatical primitives. A construction is essentially a form-meaning pairing with constraints on both form and meaning. Aspects of meaning can be contributed by the construction as a whole, not just by its participants. Constructions can be very specific, single-word (lexical), or very general, e.g. argument-structure constructions. Thus constraints can be represented at a multitude of levels so there is no single monolithic syntactic level distinct from a monolithic morphological level. A given utterance, or construct, can instantiate several different constructions at the same time; lexicalist-style unification is used to make sure that the properties of the different instantiated constructions are not in conflict. That is, a given construct can exhibit more than one mismatched pattern at the same time, but no abstract layers are required to fix the mismatch.

For Georgian, constructions can represent generalizations both about verbal agreement and about valence and nominal case marking. Verbal agreement is represented as word-level constructions specific to Series and conjugation types. Case assignment, on the other hand, is represented as 
phrase-level constructions specific to Series and conjugation types. A given phrase (or construct) unifies the agreement properties expressed by the verb with those dictated by the phrase, without requiring them to be identical.

A constructional approach to verbal agreement and phrase structure allows us to represent the mismatched patterns in a unified way. It treats possible mismatches as normal rather than exceptional, thus allowing an account of the regularity and stability of the Georgian system.

A detailed examination of grammatical relation marking in Georgian will be very useful for crosslinguistic comparisons within the Caucasus and with neighboring areas. A Construction Grammar approach allows the patterns to be represented in a clear and consistent fashion, making such comparisons easier.

\section{REFERENCES}

ANDERSON, STEPHEN R. 1992. A-Morphous morphology. Cambridge [England], and New York: Cambridge University Press.

ARONSON, HowARD I. 1990. Georgian. A Reading Grammar. Corrected Edition. Columbus, OH: Slavica Publishers.

GOLDBERG, ADELE E. 1995. Constructions: a construction grammar approach to argument structure. Chicago: University of Chicago Press.

HOLISKY, DeE ANN. 1981. Aspect and Georgian medial verbs. Delmar, N.Y.: Caravan Books.

IMEDADZE, NATELA, and KEVIN TUITE. 1992. The Acquisition of Georgian. In D. I. Slobin (ed.), The Crosslinguistic Study of Language Acquisition. London: LEA. 3, 39-109.

KAY, PAUL, and CHARLES J. FILLMORE. 1999. Grammatical Constructions and Linguistic Generalizations: The What's X Doing Y? Construction. Language 75: 1, 1-33.

TOMASELLO, MiCHAEL. 2003. Constructing a language: a usage-based theory of language acquisition. Cambridge, Mass.: Harvard University Press.

TUITE, KEVIN J. 1994. Syntactic Subject in Georgian. In H. I. Aronson (ed.), Non-Slavic Languages of the USSR. Columbus, OH: Slavica Publishers. 


\title{
GRAMMATICAL RELATIONS IN KURDIC LANGUAGES: A DIACHRONIC PERSPECTIVE
}

\author{
GEOFFREY HAIG \\ Seminar für Allgemeine und Vergleichende Sprachwisenschaft, Universität Kiel
}

It is widely assumed that ergativity in Iranian developed from a passive construction (e.g. Bynon 1979, 1980, Estival \& Myhill 1988, Campbell \& Harris 1995:243-244). On this view, the emergence of ergativity must have involved, among other things, a transfer of subject properties from the grammatical subject of the erstwhile passive construction to the Agent-phrase, which ultimately became the subject of the ergative construction. These changes are generally considered to have occurred somewhere between the Old and Middle Iranian periods.

While modern Kurmanjî Kurdish appears to offer a straightforward case of ergative alignment (cf. Haig 1998), data from lesser-known Kurdish dialects and closely related West Iranian languages (Gurani, Awroman, Mukri), suggest that the development of ergativity may in fact have had little to do with the widely-held 'transfer of subject properties' account. In Bahdinanî Kurdish (North Iraq), for example, both 'passive' and 'active ergative' functions of the same set of verb forms coexist, yet there is no evidence of an intermediate stage involving agented passives. In Gurani and Mukri, a broad spectrum of constructions with non-canonical subjects combining with intransitive verbs is attested, with no clear demarcation distinguishing them from the ergative construction. Crucially, it can be demonstrated that such non-canonical subjects already possess subject properties.

An alternative view of the emergence of ergativity would be to interpret it as the extension of an existent construction, thereby rendering an account in terms of a transfer of subject properties within the ergative construction superfluous. It will be argued that this mechanism also offers a more plausible explanation for the evolution of ergativity in the Iranian languages generally, a suggestion that follows the spirit, if not the letter, of Benveniste (1952). Finally, it is consonant with more recent accounts of the changes in Germanic from oblique to nominative subjects of Experiencer verbs (Eythórsson \& Barddal 2003), where Cole et al's (1980) approach in terms of a transfer of subject properties is called into question.

\section{REFERENCES}

BENVENISTE, E. 1952. La construction passive du parfait transitiv. BSL 48, 52-62.

BYNON, T. 1979. The ergative construction in Kurdish. Bulletin of the School of Oriental and African Studies 42, 211-224.

BYNON, T. 1980. From passive to active in Kurdish via the ergative construction. In Traugott, E., Labrum, R., and Shepherd, S. (eds.), Papers from the 4th International Conference on Historical Linguistics, 151-163. Amsterdam: Benjamins.

CAMPBELL, L. and HARRIS, A. 1995. Historical syntax in cross-linguistic perspective. Cambridge: Cambridge University Press.

Cole, P., W. HARbert, G. Hermon, and S. SRIDHAR. 1980. The acquisition of subjecthood. Language 56, 719-743.

ESTIVAL, D., and MYHILL, J. 1988. Formal and functional aspects of the development from passive to ergative systems. In Shibatani, M. (ed.), Passive and Voice, 441-492. Amsterdam: Benjamins.

EYTHÓRSSON, T., and BARDDAL, J. 2003. Oblique subjects: A Germanic inheritance! Working papers in Scandinavian Syntax 71. 145-202.

HAIG, G. 1998. On the interaction of morphological and syntactic ergativity: Lessons from Kurdish. Lingua 105, 149-173. 


\title{
SYNTACTIC AND DISCOURSIVE CONSTRAINTS OF SOME JAPANESE ADJECTIVES IN RELATION TO THEIR CONCEPTUAL DOMAINS
}

\author{
MOTOKO HORI \\ Kansai Gaidai University, Osaka
}

It has been recognized that adjectives in Japanese are unstable compared to other grammatical categories of the Japanese language. Some grammarians say that it is because they have not achieved a full development in the history of the language. This is the problem I have kept in mind for a long time: why adjectives have been left behind when other grammatical elements have reached the final stage of 'development' of the language.

With this in mind, I made an investigation of a Japanese adjective 'itai' (meaning 'painful') and have found that the conceptual distance correlates with the grammatical complexity (Hori 2004). That is, when the pain belongs to the speaker-self, the expression is the shortest, but when it belongs to another person, the expression becomes longer. This phenomenon well accords with the examples given by Croft (2001: 360). According to him, in some languages linguistic distance correlates with conceptual distance, the former being measured by the grammatical complexity and the latter by the actual relations of the person and the thing.

Based on my study of 'itai', I plan to continue investigating some other adjectives. The problems to be questioned will be: (1) what syntactic constrains exist for each adjective; (2) what conceptual distance from the speaker is implied in each adjective; (3) what is the possible concept underlying each adjective and how it affects the syntactic and discoursive constraints.

\section{REFERENCES}

Croft, WiLliam. 2001. Typology. In Aronoff, Mark and Janie Rees-Miller (eds.), The Handbook of Linguistics, 337-368. Malden, Mass.: Blackwell.

HORI, MOTOKO. 2004. The paradigm of pain expressions in Japanese. In Thompson, Geoff, and

Susan Hunston (eds.), System and Corpus: Exploring Connections. London: Equinox. In print. 


\title{
THE CASE OF OBJECTS IN FINNO-UGRIC
}

\author{
EDIT JAKAB \\ Université du Québec à Montréal, Montreal
}

In this paper, I examine nonfinite and "defective" finite modal constructions which contain a direct object whose case is nominative instead of the canonical accusative within the Finno-Ugric language family. I concentrate on the following languages: Finnish (Fi), Estonian (Est), Hungarian (H), Mari (Mar), and Moksha Mordvin (Md). The nonfinite constructions include infinitival sentences containing an invariant modal predicate and an infinitive whose direct object is nominative, illustrated in (1$3)^{1}$.

(1) Sinu-n täyty-y osta-a uusi talo.

you-gen must-3sg buy-inf new-nom house-nom

'You have to buy a new house.'

(2) See raamat tuleb teil läbi lugeda. ${ }^{2}$. this book-nom must you-dat through read-inf

'You have to read through this book.'

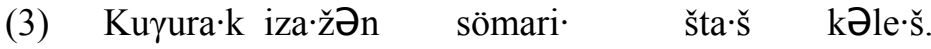

big brother-dat wedding-nom hold-inf must-3sg

'The elder brother has to arrange a wedding.'

The sentences in (4-5) demonstrate the canonical situation, i.e., when the direct object is accusative ${ }^{3}$.

(4) Minä halua-n luke-a tämän/*tämä kirjan/*kirja.

I-nom want-1sg read-inf this-acc/*nom book-acc/*nom

'I want to read this book.'

(5) Õpilane võttis raamat-u ja luges.

student-nom took book-acc and read

'The student took the book and read.'

Older stages and some current dialects of Hungarian demonstrate objects unmarked by any suffix, therefore can equally be called nominative objects. Such objects occur predominantly in nonfinite environments as well: as complements of infinitives (6-7), as complements of verbal participles (gerunds) (8), and also as complements of adjectival participles (9-10).

(6) Egy kevet-et Duna lát-ni bocsátának.

an ambassador Danube-nom see-inf sent3sg

'They sent an ambassador to see the Danube.' (Klemm 1922: 157; Pann. Megv. 30)

(7) Jöjetek el ... halott lát-ni. come-imp2pl VM dead-nom see-inf

'Come to see the dead' (Klemm 1922: 157; Arany: A varró leányok)

${ }^{1}$ It is interesting to note that the same construction is observed in Old Russian (OR), illustrated in (i). This phenomenon in OR is claimed to be the result of geographic promixity and linguistic contact with Finnic languages.

(i) Ino dostoit' mužu žena svoja nakazyvati. (OR)
for fit-3sg man-dat wife-nomF his-nomF punish-inf
'For it is fitting for a man to punish his wife.'

${ }^{2}$ The object is nominative in Estonian only if the infinitive of the modal construction is a $d a$-infinitive, such as the one in the example in (2): lugeda 'to read'. This restriction does not exist in Finnish.

${ }^{3}$ The same situation can be observed in OR, as (ii) exemplifies.

(ii) Ol'ga že povelě iskopati jamu/*jama veliku/*velika.

Olga-nom EMPH ordered dig-inf hole-accF/*nom large-accF/*nom

'Olga ordered to dig a hole.' 


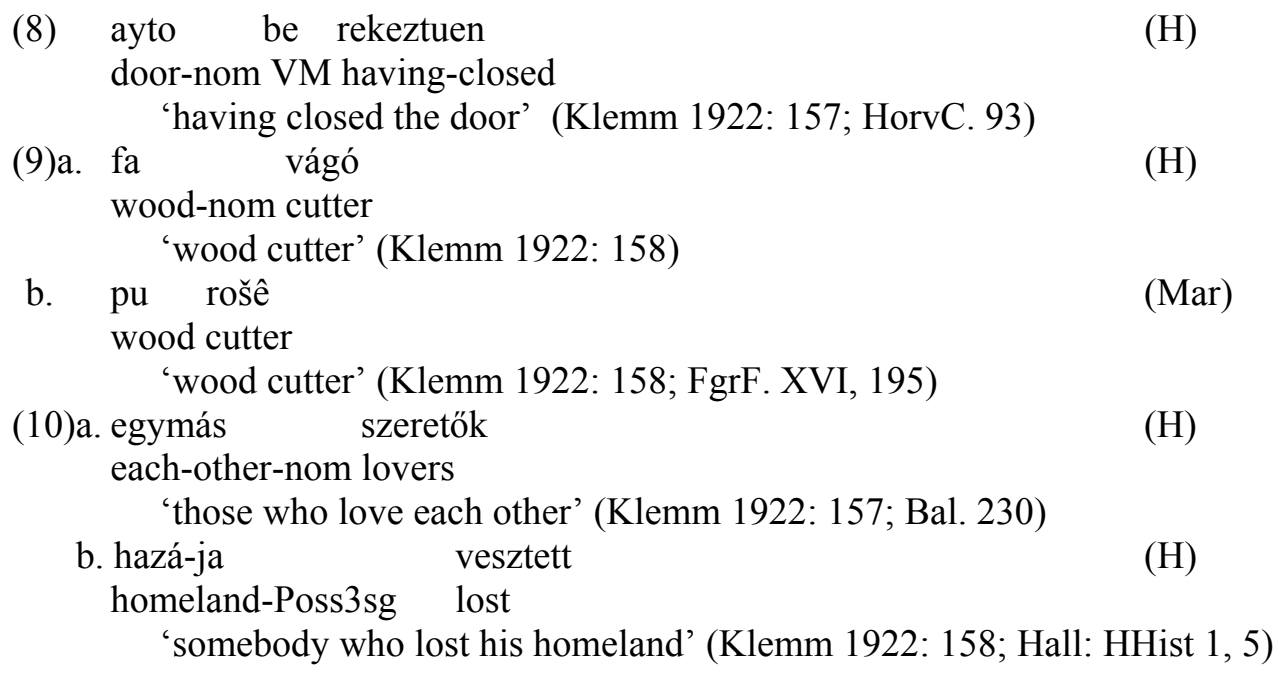

The "defective" finite constructions include imperatives that take a direct object in the nominative case, as in (11-14).
(11) Lue
(sinä) tämä kirja!
read-impv-2sg (you-nom) this-nom book-nom
'Read this book.'
(12) Too raamat siia! bring book-nom here
'Bring the book here.'
(13) Eszem a lelk-e! eat-1sg the soul-3PossSg
'I eat his soul.' (Klemm 1922: 160; typical of folk language)
(14) Fogd ez a nyulfark! hold-imp2sg this the rabbit-tail
'Hold this rabbit tail.' (Klemm 1922: 160; Arany II, 252)

Another Finno-Ugric language, namely Mordvin, also possesses nominative objects. In this language, indefinite direct objects are always nominative ${ }^{4}$ regardless of the type of construction in which they occur, as in (15).

(15) Son šužärńä poŕi.
he straw-nom chews
'He (the mouse) is chewing a piece of straw.'

On the basis of Finno-Ugric data such as (15), I propose that the notion of specificity is connected to the category of the direct object. Another example for this claim can be found in Finnish: when the direct object is a personal pronoun, a referential (specific) element, as in (16), the direct object's case is the canonical accusative in the same nonfinite (cf. (1-3) or "defective" (cf. 6-14) environments, that otherwise require the direct object to be nominative ${ }^{5}$.

$$
\begin{aligned}
& \text { (16)a. Sinu-n täyty-y kutsu-a minu-t/*minä. } \\
& \text { you-gen must-3sg invite-inf I-acc/*nom } \\
& \text { 'You have to invite me.' }
\end{aligned}
$$

\footnotetext{
${ }_{5}^{4}$ Indefinite direct objects are nominative also in Mari as well as in several Turkic languages.

${ }^{5}$ It is interesting to note that in OR the issue of specificity manifests itself in terms of "animacy". Only direct objects of inanimate categories can be nominative; i.e., inanimate masculine and all feminine NPs (animate masculine NPs receive the canonical accusative case) (cf. Timberlake 1974).
} 


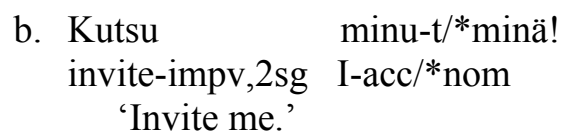

Assuming Di Sciullo's (2000) framework, I propose that the difference in case follows from an asymmetrical relation between lexical and functional features. Consequently, case checking equals identification of case features under local asymmetry in either the lexical or the functional domain. Thus, in modal infinitivals (1-3), the NP direct objects are merged with nominative case in Spec-VP, and thus case checking (i.e., case identification) happens in situ in the lexical domain. On the other hand, direct object pronouns (16) are generated in the functional projection DP in the complement position of $\mathrm{V}$ with accusative case since pronouns are not lexical categories (i.e., they are not part of the lexical domain, and thus necessarily behave differently from full NPs. In this theory, only lexical categories ( $\mathrm{N}$ and $\mathrm{V}$ ) are part of the lexical domain. All others, including pronouns (D), belong to the functional domain. Hence the difference between the case realization of NP and pronominal direct objects boils down to the difference in their case identification, i.e., shifting (merge) or linking (movement), respectively.

Besides the major difference in the case of direct objects in Finnish (i.e., direct objects of imperatives and infinitives embedded in a modal context are nominative), there are several differences in the case of the direct objects even within these well-defined circumstances: the direct object of 1st and 2nd person imperatives is marked as the nominative case (cf. (6)), whereas the direct object of 3 rd person imperatives is marked as accusative (cf. (17)).
(17)a. Luke-koon hän kirja-n. read-impv,3sg (s)he-nom book-acc 'May he/she read the book.'
b. Hän luke-koon kirja-n.
(s)he-nom read-impv,3sg book-acc
'May he/she read the book.'

It will be shown that the difference in the feature specification of second and third person imperatives coincides with their pattern of subject omission ${ }^{6}$. I propose that the nominative direct object $\mathrm{NP}$ of $1^{\text {st }}$ and $2^{\text {nd }}$ person imperative verbs is generated in Spec-VP where it checks its nominative case in situ (also, there is no obligatory nominative subject present in such sentences). The optional occurrence of a nominative-cased subject thus does not cause a theoretical problem and it is structurally accounted for (without the proliferation of functional projections, as in Mitchell 1991), i.e., it checks its case in Spec-AgrSP. On the other hand, the direct object of $3^{\text {rd }}$ person imperatives is generated in the complement position of $\mathrm{V}$ with accusative case. This assumption is supported by the obligatory presence of a nominative subject NP in the sentence.

The advantage of this proposal is that it ties together two distinct properties of second and third person Finnish imperatives in accounting for the case difference that their direct objects display. When the imperative has an obligatorily overt nominative subject, it takes a direct object in the accusative in the cross-linguistically canonical way. On the other hand, when the imperative's subject (i.e., ImpNP) is not necessarily overt, the direct object's case is nominative. Notice that even when the ImpNP is overt, it cannot occupy the regular sentence-initial subject position: it always follows the verb (in contrast with (10b)). The regular absence and the position of the ImpNP suggests that it has different properties from those of regular subjects (cf. Platzack \& Rosengren 1998). Consequently, its case is a weaker nominative, which allows the presence of another nominative (the direct object) in the same clause. Platzack \& Rosengren 1998 suggests that the ImpNP can be considered to be caseless since imperatives lack the case-checking TP position. While this suggestion might be correct, I suggest that the nominative case of ImpNPs is checked in AgrSP (there is an AgrS projection since the ImpNP agrees with its subject) (cf. Iatridou 1993).

\footnotetext{
${ }^{6}$ Finnish is a "mixed" pro-drop language, i.e., it allows an empty subject in first and second person, but the presence of the subject is obligatory in third person (cf. Vainikka \& Levy 1999).
} 
The paper also shows that previous hypotheses (Timberlake 1974, the Case Tier Hypothesis (1985), or Mitchell 1991) cannot account for all the data, e.g., they fail to explain the possibility of two nominative NPs in the same clause. Furthermore, they do not provide a formal mechanism for the nominative object to check its [-interpretable] feature, and they do not indicate where and how the nominative object checks its nominative case, i.e., whether it differs from the way in which the nominative subject checks its case.

Finally, the Hungarian data will be explained by a diachronical syntactic process, namely, the reanalysis of certain syntactic functions.

\section{SELECTED REFERENCES}

BereCZKI, G. 1990. Chrestomathia Ceremissica. Budapest: Tankönyvkiadó.

CHOMSKY, N. 1998. Minimalist Inquiries: The Framework. Ms. MIT.

Di SCIULLO, A.M. 1999. Local Asymmetry. MITWPL 35:23-67.

EMONDS, J. 1989. Timberlake's Nominative Objects in Finnish and Old Russian. Talk given at LSA.

HAKULINEN, A., and F. KARLSSON. 1979. Nykysuomen lauseoppia [Syntax of Modern Finnish]. Jyväskylä, Finland: SKS.

Holmberg, A., and U. NIKANNE, eds. 1993. Case and Other Functional Categories in Finnish Syntax. Berlin: Mouton.

IATRIDOU, S. 1993. On Nominative Case Assignment and a Few Related Things. In MIT Working Papers in Linguistics 19, 175-196.

JAKAB, E. 2000. Nominative Object Constructions in Old Russian and Finnish. In T. Holloway King \& I. A. Sekerina, eds., Annual Workshop on Formal Approaches to Slavic Linguistics: The Philadelphia Meeting 1999, 168-188. Ann Arbor: Michigan Slavic Publications.

LAVOTHA, Ö. 1973. Kurzgefasste estnische Grammatik. Veröffentlichungen der Societas UraloAltaica, v. 9. Wiesbaden.

KereszTES, L. 1989. Chrestomathia Morduinica. Budapest: Tankönyvkiadó.

KLEMM, A. 1922. In K. Szily, ed., Magyar Nyelv, 156-160. Budapest: Magyar Nyelvtudományi Társaság.

Mitchell, E. 1991. Case and the Finnish Object. Cornell Working Papers in Linguistics 9, 193-228.

PlatzaCK, C., and I. Rosengren. 1997. On the Subject of Imperatives: A Minimalist Account of the Imperative Clause. In K. Safir \& G. Webelhuth, eds., The Journal of Comparative Germanic Linguistics, 177-224.

SPRINČAK, JA.A. 1960. Očerk russkogo istoričeskogo sintaksisa. Kiev: Radjans'ka škola.

TARAlDSEN, T. 1985. On the Distribution of Nominative Objects in Finnish. Proceedings of the 12th Scandinavian Conference on Linguistics. Joensuu: University of Joensuu.

TIMBERLAKE, A. 1974. The Nominative Object in Slavic, Baltic, and West Finnic. Slavistische Beiträge 82. München: Verlag Otto Sagner.

TIMBERLAKE, A. 1975. The Nominative Object in Finnish. Lingua 35, 201-230.

URA, H. 1996. Multiple Feature-Checking: A Theory of Grammatical Function Splitting. Ph.D. dissertation, MIT, Cambridge, Mass.

VAINIKKA, A. \& Y. Levy. 1999. Empty Subjects in Finnish and Hebrew. Natural Language and Linguistic Theory 17, 613-671.

YIP, M., J. MALING, and R. JACKENDOFF. 1987. Case in Tiers. Language 63, 217-250. 


\title{
TOPIC MARKING AND THE CONSTRUCTION OF NARRATIVE IN SIBE
}

\author{
TAEHO JANG and TOM PAYNE \\ University of Oregon, Department of Linguistics
}

The Sibe language is the language spoken by those members of the Sibe nationality that live in northwest China. The Sibe in northwest China are the descendants of thousands of Sibe soldiers and their families who were assigned to Xinjiang (present day Xinjiang Uygur [Uighur] Autonomous Region) from northeast China in 1764. The Sibe language belongs to the ManchuTungus branch of the Altaic family of languages. It has the largest number of speakers of any language belonging to that branch. Most of the data for this paper is drawn from natural discourse, relying primarily on a corpus of folktale narratives recorded by T. Jang.

In this paper we show that there is a prototypical grammatical construction in Sibe that functions to advance the foregrounded portion of a narrative text. This construction crucially involves the particle $d a$ in interesting and varied usages. The particle $d a$ occurs in four syntactic contexts in our corpus, but is never "obligatory" in any particular context. In other words, it is a particle that is constrained, but not determined, by syntactic structure. The central question that we address in this paper is what semantic and/or pragmatic factors influence or determine a speaker's choice to use or omit $d a$ in any particular environment in which it may occur.

Our conclusion is that the usages of $d a$ are sensitive to a cluster of semantic and pragmatic properties extending from a prototype in which $d a$ marks the topic, in the sense of $\mathrm{Li}$ and Thompson (1976). The other usages can all be insightfully viewed as extensions of this basic use. In the process we show that Sibe is appropriately considered a topic and subject-prominent language. It is similar in this respect to Japanese and Korean. However, Sibe is more flexible in what may be the topic constituent in topic-comment sentences. Therefore Sibe is closer to the topic-prominent end of the topic/ subject-prominent continuum than either Japanese or Korean.

Finally, the usages of the discourse particle $d a$ are crucially involved in an indigenous notion of style. The frequency of $d a$ is highest in stories told by well-known and proficient storytellers. Furthermore, $d a$ is virtually absent in daily conversation, and its use lends a highly valued element of formality, or even archaism to narrative text. This study, therefore, provides a preliminary template for how linguistic analysis may inform a fundamental characterization of genre, style and literary esthetics. 


\title{
ON THE HIERARCHY OF STRUCTURAL CONVERGENCE IN THE AMDO SPRACHBUND
}

\author{
JUHA JANHUNEN \\ University of Helsinki, \\ Institute for Asian and African Studies \\ Department of East Asian Studies
}

The Amdo Sprachbund, also known as the Qinghai-Gansu Sprachbund (Slater 2003), comprises ca. 15 languages and/or principal dialects spoken in the Sino-Tibetan borderland historically known as the Amdo Province of Ethnic Tibet, and today divided between the Gansu and Qinghai Provinces of China. The languages of the Sprachbund belong to four linguistic stocks: Turkic (Sarygh Yughur, Salar), Mongolic (Shira Yughur, Huzhu Mongghul, Minhe Mangghuer, Qinghai Bonan, Gansu Bonan, Kangjia, Santa), Sinitic (Northwest Mandarin, Hezhou, Tangwang, Gangou, Wutun), and Bodic (Amdo Tibetan, with variants). All of the idioms concerned have undergone interactive adaptations, which may be seen as manifestations of mutual "creolization". Speaking of "creoles" in the proper sense of the term is nevertheless unjustified, since the distinction between the four genetic lineages remains synchronically unambiguous, as is evident from the genetically diagnostic sections of linguistic substance (basic vocabulary, morphological elements). Outside of the Amdo Sprachbund, but partly within the same physical region, other languages are spoken which also represent the same four linguistic stocks: Turkic (Kazakh), Mongolic (Qinghai Oirat), Sinitic (Standard Mandarin), and Bodic (Khams Tibetan, marginally also variants of Central Tibetan).

The mutually conditioned structural developments observed in the languages of the Amdo Sprachbund may be divided into four categories: active positive (adoption of a new feature), active negative (loss of an original feature), passive positive (retention of an original feature), and passive negative (non-adoption of a new feature) (Janhunen 2001). As a result, the participants of the Sprachbund share a significant number of properties at all levels of linguistic structure (phonology, morphology, morphosyntax, syntax, discourse). Not all properties are shared by all the participants, however. Diachronically, it is possible to operate with three typological spheres, which variously cover the languages of the Sprachbund: the Altaic sphere, the Sinitic sphere, and the Bodic sphere. Features representing the Altaic sphere (as understood in the typological sense only) are mainly manifested as a general substratum, uniformly present in all the languages of the Sprachbund, while features representing the Sinitic and Bodic spheres are often, though not necessarily, mutually exclusive. Thus, the Sinitic and Bodic languages of the Sprachbund may be said to share a basic Altaic typological orientation with their Turkic and Mongolic partners. The contrast between the Sinitic and Bodic spheres is most clearly observed in the Mongolic languages of the Sprachbund, which can have an exclusively Sinitic orientation (Santa), an exclusively Bodic orientation (Shira Yughur, Huzhu Mongghul, Qinghai Bonan), or a primary Bodic orientation upon which secondary Sinitic features have been added (Minhe Mangghuer, Kangjia, Gansu Bonan).

Apart from the overall Altaic orientation of all the languages of the Amdo Sprachbund (the highest level of interaction), and the cumulative impact of the contrasting Sinitic and Bodic typological spheres (the medium level of interaction), there are also more localized relationships of structural adaptation (the lowest level of interaction). These are manifested as an even closer convergence especially at the morphosyntactic and phonotactic levels, making the participating idioms mutually fully convertible both morphologically (isomorphy) and phonologically (isophony). Even in such cases, at least synchronically, one of the languages seems to be the dominant partner, while the other(s) take(s) a recessive position, as can be deduced from the generally unilateral forms of bilingualism. The most obvious such case is formed by Minhe Mangghuer (dominant) and Gangou (recessive) (Zhu \& al. 1997), but the areal union between Santa (dominant) and Tangwang (recessive) may also turn out to be a relevant example. Another pair of convergent languages is formed by Qinghai Bonan and Wutun, though it is difficult to establish for the time being to what extent their parallelism is due to their immediate mutual interaction, and to what extent it is conditioned by their independent convergence under the impact of the local form (the Rebgong dialect) of Amdo Tibetan (the dominant form of speech and lingua franca in the area). 
Although the structural properties characteristic of the Amdo Sprachbund are present in several languages in parallel, it is generally possible to single out for each property the specific linguistic stock, or stocks, from which the property ultimately derives. At the syntactic level, for instance, the basic word order in the Sprachbund is SVO, which is typically an Altaic (as well as, possibly, Bodic) feature secondarily introduced into the Sinitic (as well as, possibly, Bodic) languages of the Sprachbund. At the morphosyntactic level, Altaic (as well as, partly, Bodic) features include the systems of suffixally (or postclitically) marked nominal cases and verbal tense-aspect categories. The use of postpositions (often with genitive rection) seems also to be a feature deriving mainly from the Altaic sphere of the Sprachbund. On the other hand, the loss of the category of suffixally marked personal conjugation in the Turkic languages of the Sprachbund (Sarygh Yughur, Salar), as well as the non-introduction of personal conjugation in the Mongolic languages of the Sprachbund (in deviation from several other branches of Mongolic), clearly represent the impact of the Sinitic and Bodic typological spheres. An important feature of the discourse level contributed to the Amdo Sprachbund by Bodic (Amdo Tibetan) is the category of perspective, documented to a varying degree from several Turkic (Sarygh Yughur, Salar?), Mongolic (Shira Yughur, Huzhu Mongghul, Minhe Mangghuer, Qinghai Bonan, Gansu Bonan, Kangjia?), and Sinitic (Gangou? Wutun?) languages of the region. Another Bodic (supported by Sinitic) feature is the presence of a final indefinite article (from the numeral 'one') in some of the Mongolic languages of the Sprachbund (Huzhu Mongghul, Minhe Mangghuer, Qinghai Bonan, Gansu Bonan).

From the analysis of the structural features shared by the languages of the Amdo Sprachbund it is obvious that certain structural properties were liable to be transmitted by areal contact, while others were not. In contrast to the conventional understanding of "creolization", it would be wrong to view the diachronic developments that have taken place in the participating languages as manifestations of a tendency towards overall grammatical simplification, in which the Sprachbund would end up exhibiting the smallest common denominator for each given feature. For instance, the loss (or nondevelopment) of personal conjugation in some languages of the Sprachbund may be seen as a simplification, but the effect of this simplification is counteracted by the parallel adoption of the new category of perspective, which in some respects overlaps functionally with the category of person. It is simply not possible to determine which feature is universally less complex, personal conjugation or a grammaticalized system of perspective (though the latter is certainly less frequent among the languages of the world). The real issue is, however, why it was the category of person that receded in the Amdo Sprachbund, while the category of perspective expanded into new languages. This may have been connected with the demographic and cultural power relations of the languages concerned, but it is also possible that there is an inherent, though not necessarily universal, hierarchy of structural convergence, rendering some features more liable to be borrowed than others.

If the assumption of a hierarchy of structural convergence is correct, it is interesting to have a look at such features in the languages of the Amdo Sprachbund that have generally not been transmitted across language boundaries. It is not impossible that such features represent exceptionally persistent and, consequently, conservative properties of language, on a par with the contrast between headmarking and dependent-marking grammars (Nichols 1986). Not surprisingly, among such features we find the basic difference between accusative and ergative strategies of sentence structure. In the Amdo Sprachbund, Amdo Tibetan (like other forms of Tibetan) is consistently an ergative language, and in spite of its otherwise Altaic sentence structure it has not adopted the accusative strategy of Altaic typology. On the other hand, the Turkic and Mongolic languages of the Amdo Sprachbund keep their original accusative strategy with the only complication that the Mongolic (but not the Turkic) languages of the region have replaced the actual accusative by a syncretic connective case which also functions as a genitive (Janhunen 2002). Interestingly, the Sinitic languages of the region have generally adopted the accusative model (with no syncretism between accusative and genitive), while the ergative strategy seems to have remained alien to them. This may be connected with the fact that the direct impact of Bodic on Sinitic in the Amdo Sprachbund is rare (the only exception being Wutun). A secondary ergative is, however, reported from a "creolized" variety of Chinese (Daohua) spoken in Northern Sichuan (Ye.shes.vod.gsal xA.tshogs 2003).

Another apparently conservative feature for which the languages of the Amdo Sprachbund retain their original structural diversity is the word order of the nominal phrase. The languages belong- 
ing to the Altaic and Sinitic typological spheres exhibit the widespread Altaic (and Sinitic) word order GAN, in which both the genitival $(\mathrm{G})$ and the adjectival (A) attribute precede the head noun. Amdo Tibetan (like other forms of Tibetan), by contrast, belongs to the Southeast Asian area of languages in which the adjectival attribute (including adjectivally used numerals and pronouns) follows the head noun, while only the genitival attribute precedes the head noun, yielding the order GNA (Dryer 2003). With the exception of the final indefinite article (based on the numeral 'one'), as well as the occasional use of borrowed Tibetan numerals in a Mongolic context (Qinghai Bonan), this feature seems not to have crossed language boundaries within the Amdo Sprachbund, leaving a fundamental structural difference between the Bodic and non-Bodic languages of the region.

It has to be noted that almost all the languages and dialects of the Amdo Sprachbund, including even those for which relatively large systematic grammars and/or dictionaries are available (Sarygh Yughur, Salar, Huzhu Mongghul, Minhe Mangghuer, Amdo Tibetan), are still insufficiently documented, especially as far as their syntactic and discourse properties are concerned. It will take a lot of more effort to map their individual grammatical systems in detail, so that a more comprehensive understanding of their shared properties and areal relationships can arise. A fortunate circumstance in this context is that almost all of the languages (and even dialects) concerned are still alive, being transmitted to the next generation. Therefore, the Amdo Sprachbund remains a promising laboratory for future fieldwork on contact linguistics.

\section{REFERENCES}

DRYER, MATTHEW S. 2003. Word Order in Sino-Tibetan Languages from a Typological and Geographical Perspective. In Graham Thurgood \& Randy La Polla (eds.), The Sino-Tibetan Languages. Routledge Language Family Series, vol. 3, 43-55. Routledge Curzon: London \& New York.

JANHUNEN, JUHA. 2001. Typological Interaction in the Qinghai Linguistic Complex. Paper presented at the 34th International Conference of Sino-Tibetan Languages and Linguistics, Kunming.

JANHUNEN, JUHA. 2002. On the Convergence of the Genitive and Accusative Cases in Languages of the Ural-Altaic Type. Guest Lecture at the University of Hamburg, Institut für FinnoUgristik.

NiCHOLS, JOHANNA. 1986. Head-marking and Dependent-marking Grammar. Language 62: 1, 56119.

SlAter, KeITH W. 2003. A Grammar of Mangghuer: A Mongolic Language of China's QinghaiGansu Sprachbund. RoutledgeCurzon Asian Linguistics Series. Routledge Curzon: London, and New York.

YE.SHES.VOD.GSAL XA.TSHOGS [YIXIWOSA ACUO]. 2003. Zang Han yuyan zai "Daohua" zhong de kunhe ji yuyan shendu jiechu yanjiu. [English abstract: Research on Mixing of Tibetan and Chinese in Daohua and Relative Languages Deep-contact Study]. Ph.D. thesis, Nankai University: Tianjin.

ZHu YongZhOng, ÜJIYedin ChuluU, KeIth Slater, AND Kevin Stuart. 1997. Gangou Chinese Dialect: A Comparative Survey of a Strongly Altaicized Chinese Dialect and its Mongolic Neighbor. Anthropos 92, 433-450. 


\title{
ARGUMENT STRUCTURE AND CASE ASSIGNMENT IN THE CAUSATIVE CON- STRUCTIONS OF WESTERN NEW INDO-ARYAN LANGUAGES (HINDI-URDU, PUNJABI, GUJARATI, RAJASTHANI)
}

\author{
LJUDMILA VIKTOROVNA KHOKHLOVA \\ Moscow State University \\ Department of Indian Philology, \\ Institute of Asian and African Studies
}

This paper explores the properties of the causative constructions found in some Western NIA languages. It shows that: 1) assignment of instrumental vs. dative/accusative case to the causee reflects the thematic role of the argument in that construction (agent vs. beneficiary); 2) morphological operations (e.g., addition of a second causative morpheme) do not always parallel syntactic operations such as changes in argument structure.

The process of causativization in Western NIA languages depends upon the syntactic and semantic properties of the underlying verbs. Four main syntactic subclasses of verbs may be singled out in Western NIA languages: 1) 'intransitives' (of the type 'to be cut'); 2) the so called 'ingestive' transitives (e.g., 'to eat'); 3) 'non-ingestive transitives' ('to do' and the like) and 'double transitives' (e.g., 'to give').

The first level of derivation results in (a) single-object transitive verb if the underlying verb is intransitive: 'to be cut' - 'to cut'; (b) double object transitive verb if the underlying verb belongs to the 'ingestive' class: 'to eat' - 'to feed'; (c) causative verb if the underlying verb belongs either to the transitive? class: 'to do' - 'to get done' or to the class of inherent double object verbs: 'to give' - 'to arrange receiving'. As the verbs of the third class form causatives already at the first level of derivation, the second level of derivation does not imply any addition of an 'extra agent' to their verbal case frame. The verbs of the first two classes form causatives at the second level of derivation.

The causee of 'ingestive' verbs is Recipient, marked by Dative/Accusative case. The causee of non-ingestive verbs is usually Mediator (causee agent) marked by Instrumental/Ablative case. However, some 'non-ingestive' verbs are regularly used with dative causees in special meanings, usually separately mentioned by dictionaries: for example, the causative from 'to write' with the dative causee means 'to dictate', while the same causative with the instrumental or ablative causee means 'to ask to write'.

Non-ingestive verbs form also 'assistive' causative constructions where the causee plays the role of Beneficiary. In fact, 'assistive' meaning does not incorporate the meaning 'cause', but in many mutually unrelated languages it may be expressed by the same marker as used for ordinary causatives. (Kulikov 2001). 'Assistive' causatives are usually mentioned but their usage in Western NIA is not really investigated by linguists, that is why they will be discussed in detail in this paper.

The usage of 'assistive causatives' varies in different Indo-Aryan languages. Hindi seems to be most intolerant to 'assistive' causative constructions when the causer and the causee perform one and the same 'physical' action like 'Ram helped Mohan to lift the luggage'. In Punjabi, Rajasthani and Gujarati equivalents of this construction are not rejected by many native speakers.

'Assistive' causatives are most acceptable in all described languages in situations when the causer performs an action different from that of the causee, but both actions are aimed at one and the same result. The causer's action may be explicitly described: 'Having poured water mother helped the child to wash face and hands', or it may be not described, but understood from the context: 'We arrest you on accusation of helping the criminal to escape'.

'Assistive' causatives represent one of the deviations from the general pattern: the causative verb differs from the non-causative counterpart in presence of an extra agent in its case frame (Balachandran 1973), (Kachru 1966), (Kachru 1973), (Kashi Wali 1989), (Mistry 1969), and others. The argument added to the case frame of 'assistive' causatives is Beneficiary, not Agent.

The properties of some other causative constructions are incompatible with the claim that morphological operations (e.g., addition of a second causative morpheme) parallel syntactic operations such as changes in argument structure (Baker 1988). When a causative morpheme is added to a verb, an extra argument is not necessarily added to the argument structure of the verb from which the 
causative morpheme is derived. The paper explores the semantic factors that can encourage the use of the causative construction without changes in the argument structure.

1) Non-volitional causation: the causer may be inanimate, animate non-human and human; the action is always performed unintentionally, accidentally; the human causer may perform some other action, that (without his desire) results in causation of the action expressed by the predicate; the action may affect either the goal or the causer himself (Gujarati does not use causatives when the action affects the causer himself).

2) Volitional causation: a) the causer and the goal demonstrate the 'whole-part' relation; b) the causee is unspecified; c) the causatives are used honorifically (mostly in Rajasthani).

\section{REFERENCES}

Balachandran, L.B. 1973. A Case Grammar of Hindi. Decennary Publication Series 7. Agra: Central Institute of Hindi.

COMRIE, B.1981. Language Universals and Linguistic Typology. Syntax and Morphology. Oxford: Basil Blackwell.

KACHRU Y. 1966. An Introduction to Hindi Syntax, 62-81. Urbana: University of Illinois.

GUASTI, MARIA T. 1996. Semantic Restrictions in Romance Causatives and the Incorporation Approach. Linguistic Inquiry 27: 2, 294-313.

KACHRU, Y. 1973. Causative Sentences in Hindi Revisited. In Braj Kachru et al. (eds.), Issues in Linguistics. Papers in Honour of Henry and Renee Kahane. 377-393. Urbana: University of Illinois Press.

KaChRU, Y. 1976. On the Semantics of the Causative Construction in Hindi-Urdu. In Masayoshi Shibatani (ed.), Syntax and Semantics 6: The Grammar of Causative Constructions, 353-369. New York: Academic Press.

KULIKOV, LEONID I. 1993. The 'second causative': A typological sketch. In Bernard Comrie, and Maria Polinsky (eds.), Causatives and Transitivity.. Studies in Language Companion Series 23, 121-151. Amsterdam/Philadelphia: John Benjamins Publishing Co.

KULIKOV, LEONID I. 2001. Causatives. Language Typology and Language Universals 2, 886-898. Berlin, and New York: Walter de Gruyter.

LIPEROVSKY, V.P. 1984. Glagol v jazyke Hindi [Verb in Hindi Language]. 45-47. Moscow: Nauka.

MISTRY, P.J. 1969. A Generative Syntax of Gujarati. Unpublished Dissertation, University of California at Los Angeles.

SAKSENA, A. 1980. The Sourse of Causative Contrast. Lingua 51, 125-136. North-Holland Publishing Company.

SYEED, SAYYID M. 1985. Morphological Causatives and the Problems of the Transformational Approach. Bloomington. Indiana University Linguistic Club.

WALI, KASHI. 1989. Marathi Syntax. A Study of Reflexives. Patiala: Indian Institute of Language Studies. 


\title{
IS THERE CASE IN HEAD-MARKING LANGUAGES?
}

\author{
ANDREJ A. KIBRIK \\ Institute of Linguistics, Russian Academy of Sciences, Moscow
}

The distinction between head- and dependent-marking of semantic relations, formulated in the work of Johanna Nichols, constutes one of the central typological parameters. Consistently head-marking languages express semantic relations on the heads rather than on dependents. In particular, relations between verbs and their arguments (actants) and adjuncts (circumstants) are expressed on verb forms, rather than on noun phrases. Traditional linguistic theory, still dominating the thinking of the majority of linguists, has assumed (implicitly) the dependent-marking pattern to be the basic one, and the head-marking the exotic one. This of course results from the dominance of the dependent-marking pattern in the languages that European linguists became familiar with in the first place, including Indo-European, Turkic, and Finnic.

Such dominance remains true with respect to the whole area of Europe and Central/Northern Asia. However, fragments of the head-marking pattern are scattered throughout this area here and there, in particular in the North-East. In this paper I propose to look at the data of languages that are technically beyond the area under consideration but are its immediate neighbors. I mean Athabaskan languages of North America that are generally thought to descend from the last wave of immigration from Siberia into America (not counting the Eskimo-Aleut languages that still reside on the both side of the Bering Straits).

Athabaskan languages constitute the core of the Na-Dene phylum that also comprises more distantly related Eyak and Tlingit languages. Athabaskan is a relatively closely related family, probably comparable to deeper branches of Indoeuropean, such as Balto-Slavic or Iranian. The Athabaskan family is composed of three geographical groups - Northern (Alaska and Western Canada), Southern, or Apachean (Southwest of the U.S.), and Pacific (U.S. Pacific coast, from Northern California northwards). My research has focused on three languages each representing one of these groups Upper Kuskokwim (Alaska), Navajo (New Mexico and Arizona), and Hupa (California).

As is very typical of native North American languages, Athabaskan languages are strongly head-marking and polysynthetic. $1^{\text {st }}$ and $2^{\text {nd }}$ person arguments are coded only as pronominal affixes on the verb. In the $3^{\text {rd }}$ person, of course, independent NPs can be used but they appear bare, without case markers. They are cross-referenced within the verb by pronominal affixes which in certain cases are null. Pronominal affixes occupy certain positions in the morphological template of the verbal word. Since almost all affixes in Athabaskan are prefixes, they are counted from right to left (root has position number 0 ). Pronominal affixes are organized according to the accusative pattern:

- arguments of one-place verbs align together with agentives (that is, agents or agent-like arguments) of two-place verbs and occupy morphological position \#2 or \#5 (depending on individual pronominal affix)

- they are contrasted to patientives (patients or patient-like arguments) of two-place verbs that occupy morphological position \#6

See some examples from Navajo. ${ }^{1}$

(1) One-place verb with an agentive argument - dahnishjáád 'I jump'

- dah ni- sh- jáád

Morph. position \# $3 \quad 2$

upward Impf- 1Sg.Nom- jump

(2) One-place verb with a patientive argument - Èinishgai 'I am white, I whitened'

\footnotetext{
${ }^{1}$ ABBREviations IN GLOSSES. Pf - perfective, Nom - Nominative, AnO - Animate object, Impf - imperfective Acc - Accusative, Sg - singular, TI - transitivity indicator, Dat - Dative, Prf - prefix of irrelevant function, Obl- Oblique.
} 
$\begin{array}{rlr}\text { - Èini- } & \text { sh- } & \text { gai } \\ \text { Morph. position \# } & 2 & \\ \text { - Prf- } & \text { 1Sg.Nom- } & \text { white }\end{array}$

(3) Two-place verb, agentive monitored

- nishteeh 'I carry him (here)'

- P- ni- sh- È- teeh

Morph.position \# $3 \quad 2$

-3.Acc- Impf- 1Sg.Nom- TI-handle.AnO

(4) Two-place verb, patientive monitored

[GôkÊÊEC] shøÈteeh 'He carries me (over there) [e.g. an invalid speaking]'

Morph. position \#

shi- b- ni- E- teeh

[to.there] 1Sg.Acc- 3.Nom- Impf-TI-handle.AnO

As is well known, there is a long debate in modern linguistics on the status of this kind of pronominal affixes. Many have proposed that they are genuine arguments of the clause, while full NPs (on the occasions when they are present) are some kind of referential supplements to morphologically coded arguments. The radical formulation of this approach encounters some problems (that are not the central concern of this paper), but it is clear that pronominal affixes bear significant resemblance in many ways to what is arguments in more familiar languages.

Traditionally, in Athabaskan studies positions \#2 (for some affixes, \#5) and position \#6 are dubbed "subject position" and "object position", respectively. My claim is that such extension of the terms "subject" and "object" is misguided. If the function of verbal positions in which pronominal affixes are inserted can be compared with anything in traditional Indoeuropean languages, it should be case markers rather than grammatical relations. Linear morphological positions code the referent's semantic roles, pretty much like case desinences in Latin.

Just as Latin would formally code the patientive argument in the equivalent of (4) by means of an Accusative form of the pronoun, Navajo codes it by means of locating the pronominal element into position \#6. This approach is more systematically represented in Table 1 where Navajo phenomena are compared with Latin and English.

Navajo

Position \#2/5

Position \#6

Position \#6/9

Preverbs (position \#11a)

\section{Latin analogy}

Nominative case

Accusative case

Dative case

Oblique cases and prepositions
English analogy

Pre-VP syntactic position

Post-verbal syntactic position

Preposition to

Various prepositions

TABLE 1: Three techniques of role marking: morphological positions (Navajo, head-marking), nominal case markers (Latin, dependent-marking) and syntactic positions (English, null-marking)

Thus morphological positions in Navajo verb are direct analogs of Latin Nominative and Accusative. I propose to call them "Nominative position", "Accusative position", etc. This terminology is reflected in the glossing I am using in the examples. One may like or dislike the idea of extending the grammatical case terminology to refer to verbal morphological positions, but in any case these two types of role coding are functionally identical. In English the coding technique is also order-based, but it is word order rather than morpheme order. Note that Sergej Jaxontov used to describe analytic languages of Eastern Asia, that are typologically similar to English in this respect, in terms of "syntactic cases".

Navajo verbal positions \#2/5 and \#6 are functionally very different from grammatical relations "subject" and "object", and extending grammatical relations terms to role marking is not just nontraditional, but notionally flawed. Grammatical relations are statuses related to behavioral properties of arguments. They can be (partly) defined in terms of coding techniques, such as nominal case desinences, morphological positions or syntactic positions, but they don't coincide with coding techniques. Calling Navajo verbal positions "subject position" and "object position" is identical to calling 
Latin - $\varnothing$ and - $m$ in Puer-ø puella- $m$ amat 'The boy loves the girl' subject and object cases, respectively. Latin is postulated to possess subject and object relations not because it has such case markers but because grammatical relations associated with the markers have a range of stable syntactic properties, such as formation of participial and infinitive constructions, reflexivization, passive, and the like.

A language like Navajo can be tested for relevance of grammatical relations, independently of the head-marking technique of coding roles that is employed by this language. Theoretically, such a language may have some of the properties that substantiate the need for postulating grammatical relations. But then it would be pronominal elements that would bear grammatical relations rather than morphological positions wherein these elements are inserted. In reality, Navajo does not stand the tests for relevance of grammatical relations, and this will be demonstrated in the paper.

Note that in Table 1 not only Nominative and Accusative, but also Dative and Oblique are postulated for the Navajo case system. Examples in (5) demonstrate the reason for postulating the Dative case in Navajo. As is clear from example (3) above, the $3^{\text {rd }}$ person Accusative pronominal element is zero. In certain constructions, such as causative in $(5 \mathrm{~b})$, non-zero $3^{\text {rd }}$ person pronoun $b(i)$ - occurs.

$\begin{array}{ll}\text { (5)a. EawóóEE } & \text { P-si-dô } \\ \text { baby } & \text { 3.Nom-Pf-sit }\end{array}$

'The baby is sitting up'
b. EawóóđE bi-s-ó-1-dô
baby 3.Dat-Pf-1Sg.Nom-TI-sit
'I am keeping the baby sitting up'

The Dative $3^{\text {rd }}$ person pronoun may appear in the same position $\# 6$ as Accusative pronoun, but the shape of the pronominal morpheme itself is different. Thus Navajo employs a mixed technique for coding semantic roles: morphological position on the verb plus the alteration of the shape of the pronominal element.

Curiously, linguists that use the terms "subject" and "object" indiscriminately to refer to an unrestricted range of phenomena, often supplement this pair of terms with the term "dative", as if it were also a grammatical relation term. This is another illustration of the frequent confusion of coding techniques and behavioral statuses.

In addition to core arguments, Navajo allows for many peripheral clause participants to also be coded on the verb. The pronominal element corresponding to such a participant occurs at the fartherst left end of the verb (position \#11b), and is followed by a preverb specifying the participant's semantic role (position \#11a).

(6)a. hastiin Easdzİ̀ ĖááCE y-e-i-P-nø-lùùz $\operatorname{man}_{\mathrm{i}} \quad$ woman $_{\mathrm{j}}$ horse 3 .Obl $\mathrm{j}_{\mathrm{j}}$-to-3.Acc $\mathrm{k}-3 . \mathrm{Nom}_{\mathrm{i}}$-Pf-lead

'The man brought/led the horse to the woman'

b. y-e-i-P-nø-lùùz

3.Obl $\mathrm{j}_{\mathrm{j}}$-to-3.Acc $\mathrm{k}$-3. Nom $_{\mathrm{i}}$-Pf-lead

'He brought/led it to her'

The example in (6a) is a three-place clause, and the verb displays three distinct case positions: counting from right to left, Nominative, Accusative, and Oblique. The Oblique pronoun is followed by the preverb - $a a$ - 'to', here surfacing as -e-. Example (6b) demonstrates that the role-marking structure remains intact when no full NPs are present in the clause.

Traditionally, grammatical relations have been viewed as nearly-elementary linguistic notions, easily identifiable in any random language. Some linguists still adhere to this view. However, there is plentiful evidence that grammatical relations are in fact very complex notions and must be attributed to individual languages with significant caution. This paper presents one additional kind of evidence supporting this view. Grammatical relations and role-coding techniques must be very clearly distinguished, both in the thinking of linguists and in linguistic terminology.

The treatment of pronominal affixes in head-marking, polysynthetic languages is a necessary prerequisite for a cross-linguistically meaningful understanding of argument structure, grammatical relations, and role-marking techniques. In Eurasia, this problem is particularly important for AbkhazAdyghean, some Uralic, and quite a few Paleoasiatic languages. 


\title{
TRANSITIVIZER VS. CAUSATIVIZER IN KOREAN AND JAPANESE
}

\author{
HEE-SOO KIM \\ University of Michigan, Ann Arbor \\ Department of Linguistics
}

Along with the decomposition analysis of a transitive verb as CAUSE plus an intransitive verb or an adjective (e.g., Lakoff 1965), transitivization (henceforth, Trns) and causativization (henceforth, Caus) have been often used without distinction, and the confusion is especially salient in languages like Korean, which has one morpheme, the $I$-suffix with phonological variants of $-i-,-h i-,-l i$ - and $k i-$, for both functions $(1,2)$. However, there has been no attempt to distinguish between them, and transitivization and causativization have been assumed to be not distinguishable (Baek 1997, Lee 1983, Chung per.com.). With a semantic notion of 'event-control', I show both the distinctions and the relationships among transitivization and different types of causation.

Shibatani and Chung (2001) is one of the most recent and well-received semantic approaches to Korean and Japanese causatives. As Figure 1 shows, they argued that there are three kinds of causations, direct $(3 \mathrm{i}, 5)$, associative $(3 \mathrm{ii}, 6 \mathrm{i})$, indirect $(4,6 \mathrm{ii})$, and these are differentiated by two factors: (i) the degree of the causer's involvement in the caused/root event (physical, partial, no involvement); (ii) whether the causing event and the root event occur at the same location (L) and time (T). They also showed that the causative semantics covered by 'lexical' or 'productive' mediums are different between Korean and Japanese (Figure 1). For example, while the 'associative causation' is encoded as a 'lexical causative' in Korean, it is constructed as 'productive causative' in Japanese. According to Shibatani and Chung (2001), a Korean I-causative (3ii) and a Japanese lexical causative (5) are both predicted that the causing event and the root event happen at the same location and time: $\mathrm{L}_{1} \mathrm{~T}_{1}$. However, native speakers say that these constructions can be used when there is not even an overlap between the LT of the causing event and the LT of the root event. Thus, Shibatani and Chung's (2001) descriptions of different causations should be reconsidered. Also, Shibatani and Chung (2001) did not mention what the 'lexical causative' morphemes are in Japanese, but Kitagawa (1999) analyses these idiosyncratic-looking morphemes as actually systematic variants of the transitivizers $-E$ and $-A S$. However, neither 'lexical causativizer' nor 'transitivizer' has ever been clearly defined though, among examples of them $(1,5,7)$, there may be fine-grained semantic difference.

I propose that a continuum of event-control can illuminate both the differences and the relationships among transitivization and different causations. By 'event-control', I mean a semantic or pragmatic relation of an NP to the event denoted by the root verb: the force or responsibility of bringing about the root event. For example, in all kinds of causatives (2 6), the NP going through a change, the child, has the ability to achieve the root event (i.e. can have event-control over the root event) no matter whether it actually works for it or not. In contrast, in (1) and (7), there is no way that the NP going through a change, the road or the door, can be considered as having event-control over the root event. However, this is not just because the argument of 'be wide (Adj)' or 'open (Vi)' is an inanimate argument. Actually, even in a typical transitive with two animate arguments such as 'Mary kicked Tom', the NP going through a change Tom has no control over someone else (e.g., Mary)'s action (e.g. kicking). ${ }^{2}$ Thus, based on these facts, I present Figure 2 and suggest that the difference between transitivization and causativization depends on whether the NP going through a change, $\beta$, can be considered to have event-control over the root event or not. ${ }^{3}$ Also, to distinguish among dif-

\footnotetext{
${ }^{1}$ I thank Prof. Acrisio Pires at the University of Michigan for his comments/suggestions.

2 This observation agrees with Jacobson (1992): transitivity is about unidirectional or at least asymmetric dominance relationship between 2 arguments.

${ }^{3}$ Since the causer's deeper/bigger involvement implies less even-control on the part of the causee, this aspect can be considered as reflected in Shibatani and Chung (2001). However, in terms of the 'causer', the differences among transitivization and diverse causations are not captured uniformly.
} 
ferent causations, I replace Shibatani and Chung's (2001) criteria (the causer's involvement and the location and time) with the degree of the event-control that $\beta$ has. Though one might say that the distinction between "co-operationg" in the associative causation and "taking charge" in the indirect causation is vague, an implicature test could serve this purpose; the grammaticality contrast between (8) and (9) shows that the indirect causation does not necessarily imply the achievement of $\gamma$ (the root event) and that its success depends more on $\beta$ rather than $\alpha$ (the NP making the change). ${ }^{4}$

In sum, by the continuum of event-control, both the semantic differences and the relationships among transitivization and different causations are captured in a unified way.

\begin{tabular}{|l|c|c|c|}
\hline & $\begin{array}{l}\text { Direct Causation } \\
\left(\mathrm{A} \rightarrow \mathrm{P}: \mathrm{L}_{1} \mathrm{~T}_{1}\right)^{5}\end{array}$ & $\begin{array}{l}\text { Associative Causation } \\
\left(\mathrm{A} \rightarrow \mathrm{A}^{\prime} \rightarrow \mathrm{P}:\right.\end{array}$ & $\begin{array}{l}\text { Indirect Causation } \\
\left(\mathrm{A} \rightarrow \mathrm{A}^{\prime}: \mathrm{L}_{1} \mathrm{~T}_{1} . \mathrm{A} \rightarrow \mathrm{P}: \mathrm{L}_{2} \mathrm{~T}_{2}\right)^{7}\end{array}$ \\
\hline Korean & lexical $-I-(-i-,-h i-,-l i-,-k i-)$ & productive $-k e y$ ha-ta \\
\hline Japanese & lexical & productive -sase- \\
\hline
\end{tabular}

FIGURE 1.

\begin{tabular}{|l|l|l|l|l|}
\hline & $\begin{array}{l}\text { Transitivization } \\
(\beta \text { cannot have any } \\
\text { control over } \gamma .1,7)\end{array}$ & $\begin{array}{l}\text { Direct Caus } \\
(\beta \text { neither works for } \\
\text { nor resist } \gamma .3 \mathrm{i}, 5)\end{array}$ & $\begin{array}{l}\text { Associative Caus } \\
(\beta \text { co-operates with } \\
\alpha \text { working for } \gamma .3 \mathrm{ii},\end{array}$ & $\begin{array}{l}\text { Indirect Caus } \\
(\beta \text { takes charge of } \gamma . \\
4,6 \mathrm{ii})\end{array}$ \\
\hline Korean & \multicolumn{2}{|c|}{$-I-(-i-,-h i-,-l i-,-k i-)$} & $-k e y$ ha-ta \\
\hline Japanese & $-E-,-A S$ & & -sase- \\
\hline
\end{tabular}

FIGURE 2. ( $\alpha$ : NP making the change. $\beta$ : NP going through the change. $\gamma$ : root event).

(1) inpwu-ka cop-un kil-ul nelp-hi-ess-ta. $\quad$ Kor. $^{8}$ worker-Nom narrow-Rel road-Acc wide(Adj)-I ${ }^{9}$-Past-Dec

'The worker widened the narrow road.'

(2) sensayngnim-i cip-ey ka-nun ai-lul uyca-ey anc-hi-ass-ta. teacher-Nom house-at/to go-Rel child- Acc chair-at/in sit(Vi)-I-Past-Dec

'The teacher made the child, who was going home, sit down on the chair.'

(3) emeni-ka ai-eykey os-ul ip-hi-ess-ta. - Kor.

mother-Nom child-Dat clothes-Acc wear(Vt)-I-Past-Dec

(i) 'The mother put the clothes on the child (and the child didn't make any effort).' -

Direct Caus

\footnotetext{
${ }^{4}$ Though the achievement of the root event is implied in transitivization and direct and associative causations, these three can easily be differentiated by $\beta$ 's role.

${ }^{5}$ The causer (A) is actively and physically involved in achieving the root event, without the causee (A')'s action involved ( $\mathrm{P}$ : the patient of the root event). The causing event and the root event occur at the same location/time $\left(\mathrm{L}_{1} \mathrm{~T}_{1}\right)$.

${ }^{6}$ The causer's physical involvement in partial; the causer accompanies/assists/supervises the causee(A')'s achieving the root event. The causing event and the root event occur at the same location/time $\left(\mathrm{L}_{1} \mathrm{~T}_{1}\right)$.

${ }^{7}$ The causer is not at all physically involved in achieving the root event, and the causee(A') works alone on the Patient $(\mathrm{P})$. The causing event and the root event occur at different locations/times $\left(\mathrm{L}_{1} \mathrm{~T}_{1}, \mathrm{~L}_{2} \mathrm{~T}_{2}\right)$.

${ }^{8}$ Korean.

${ }^{9}$ The $-I-$ is the archimorpheme for $-i-,-h i-,-l i$ - and $-k i-$, that are treated either as transitivizer/intransitivizer or as causativizer/passivizer.
} 
(ii) 'The mother helped/supervised the child's putting on the clothes.' - Associative Caus

(4) emeni-ka ai-eykey os-ul ip-key-ha-yess-ta. - Kor. mother-Nom child-Dat clothes-Acc wear-Comp-do-Past-Dec

'The mother had (e.g., by telling) the child put on the clothes (the mother: no action).'

- Indirect

(5) hahaoya-ga kodomo-ni huku-o ki-se-ru. - Jap. ${ }^{10}$ mother-Nom child-Dat clothes-Acc wear(Vt)-AS(Trns)-Infinitive

'The mother put the clothes on the child (and the child didn't make any effort).' - Direct Caus

(6) hahaoya-ga kodomo-ni huku-o ki-sase-ta. - Jap. mother-Nom child-Dat clothes-Acc wear-SASE(Caus)-Past

(i) 'The mother helped/supervised the child's putting on the clothes.' - Associative Caus

(ii) 'The mother had (e.g., by telling) the child put on the clothes (the mother: no action).' - Indirect Caus

(7) Hanako-ga doa-o ak-e-ru.

Nom door-Acc open(Vi)-E(Trns)-Infinitive

'Hanako opens the door.'

(8) *emeni-ka ai-eykey os-ul ip-hi-ess-una ai-ka ip-cianh-ass-ta. mother-Nom child-Dat clothes-Acc wear-I-Past-but child-Nom wear-not-Past-Dec

'The mother helped/supervised the child's putting on the clothes, but the child didn't put them on.'

(9) emeni-ka ai-eykey os-ul ip-key-ha-yess-una ai-ka mother-Nom child-Dat clothes-Acc wear-Comp-do-Past-but child-Nom ip-cianh-ass-ta. wear-not-Past-Dec

'The mother had the child put on the clothes, but the child didn't put them on.'

\section{REFERENCES}

BAEK, M. 1997. The Korean I-Suffix: A Functional Approach. PhD Dissertation. Rice University. JACOBSEN, WeSLEY M. 1992. The Transitive Structure of Events in Japanese. Tokyo: Kuroshio Shuppan.

Kitagawa, Chisato, and Fuji, Hideo. 1999. Transitivity Alternation in Japanese. MIT Working Papers in Linguistics 33. MIT.

LAKOFF, G. 1965. On the Nature of Syntactic Irregularity. Mathematical Linguistic and Automatic Translation, Report No. NFS, 16. The Computation Laboratory of Harvard University.

LEE, IK-SUP, and YIM, HONG-BIN. 1983. Kwuke Mwunpeplon.

ShiBATANI, M., and ChUNG, S-Y. 2001. Japanese and Korean Causative Revisited. Japanese / Korean Linguistics 11.

\footnotetext{
10 Japanese.
} 


\title{
PREDICATE-ARGUMENT STRUCTURES IN TAZ-TURUKHAN \\ DIALECT OF SELKUP
}

\author{
ARIADNA I. KUZNETSOVA \\ Moscow State University
}

The present paper tells about different predicate-argument structures of the government in Selkup. The verb can govern the concrete case and predicate, if predicate depends on the predicate of the main clause. Predicate-argument structures are based on grammatical relations and on semantics of verb. 


\title{
COMPLEMENTS SYSTEMATICALLY FOLLOW THEIR HEAD AND ATTRIBUTES PRECEDE IT IN THE RELATOR AREA
}

\author{
WiLly VAn LANGENDONCK, PierRe SWigGers \& MARK VAN DE VeldE \\ University of Leuven, Belgium
}

This paper discusses the importance of argument structure for the word order of a large number of European languages. It presents some preliminary results of a research project on word order typology at the University of Leuven. We will first point out striking similarities in the word order of several genetically unrelated European languages. Then we will explain these in terms of our model of competing motivations and finally we will compare our solution to the Head-Complement Theory, a proposal made and immediately rejected by Matthew Dryer (1992:106).

1. The Relator AREA. From the point of view of classic word order theories (i.e. those before Dryer's Branching Direction Theory and Hawkins' Performance Theory), English word order is problematic : there is a split between pairs of elements in which the head precedes the dependent and pairs of elements in which the head follows the dependent. This can be illustrated with the following examples :

$\begin{array}{ll}\text { head-dependent: } & \\ \text { V-O } & \text { (I) read-a book } \\ \text { Prep-NP } & \text { in-the basket } \\ \text { Sub-Cl } & \text { because-she loves } \\ \text { N-Rcl } & \text { examples-that I } \\ \text { N-Gen } & \text { uncle-of Gerald } \\ & \\ \text { dependent-head: } & \\ \text { Adj-N } & \text { good-guys } \\ \text { Gen-N } & \text { Gerald's-uncle } \\ \text { Dem-N } & \text { this-cake } \\ \text { S-V } & \text { he-drinks } \\ \text { Adv-Adv } & \text { very-well }\end{array}$

English is not an isolated case in this respect. It is the westernmost language of a large area with strikingly similar word order, which cuts across genetic subgroupings. This area includes the Scandinavian languages, Mordva, the Fennic languages (Livonian, Estonian, Votic, Ingrian, Finnish, Karelian \& Veps), Northern Saamic, the Slavic languages and to a certain extent Karaim.

2. THE RELATOR PRINCIPLE. It would lead us too far to criticise Hawkins' and Dryer's approaches here. Instead, we will limit ourselves to presenting our description and explanation of the facts. Two preliminary remarks have to be made. First, we consider words to be the basic elements of which serialisation has to be described and explained, not constituents, grammatical relations or other units. Second, constructions should be considered in their own right. The traditional approach of only considering binary patterns is arbitrary. These remarks can be illustrated by means of two genitive constructions in English:

\section{Edward's brother}

the corner of the house

Usually these are presented as word order alternatives for a binary structure of a noun and a semantically defined genitive, i.e. of the house is fully identified with Edward's. In our view these are not word order alternatives whatsoever, but alternative encoding strategies for the genitive relation. The internal ordering in both constructions has to be accounted for individually. In the case of the ' $s$ genitive two words are involved, in the case of the prepositional genitive three. Thinking in terms of binary patterns makes it impossible to see that elements like of, which we call relators, are iconically 
placed in between their relata (corner and house) in English. In fact, $2^{\text {nd }}$ relata can be equated with complements.

A relator, a notion we adapted from Functional Grammar (e.g. Dik 1989), is a word or morpheme that has two syntagmatic slots (relata) in its semantic-syntactic structure such that the relator defines a specific semantic-syntactic relation between the two relata. The first relatum is more prominent, but is also more varied in nature than the second, its presence being in general less obligatory. As a rule, the second is obligatory because it has a tighter bond with its relator. The slot of the $2^{\text {nd }}$ relatum sometimes contains more than one filler. Adpositions, relative pronouns, subordinators, verbs and case markers are all relators.

It is now easy to describe the word order of the languages enumerated above ("relator languages"). Relators with word status are placed iconically in between their relata, more precisely after the first and before the second relatum. Constructions involving no relator have dependent-head serialisation. Carola Trips recently argued that modern English word order was to a very high extent shaped under Danish influence. It might be no coincidence that the relator area coincides with the regions once dominated by Vikings. Investigating this possibility lies beyond the scope of our project, however.

3. THE HEAD COMPLEMENT THEORY. Matthew Dryer's large cross-linguistic survey of word order is confined to binary patterns and compares the order of pairs of different kinds of elements to the order in the pair verb-object. Nevertheless, some of his empirical findings are in line with ours. He found that not all pairs of head and dependent are correlation pairs (i.e. correlate with the pair verb-object) and concluded that the head-dependent theory in its simplest form must be wrong. But on the other hand he noted that all pairs of head and complement are correlation pairs, e.g. complementizer-S and copula-predicate. Therefore he formulated the following principle (p106):

The Head-Complement Theory (HCT): Verb patterners are heads and object patterners are complements. That is, a pair of elements $\mathrm{X}$ and $\mathrm{Y}$ will employ the order $\mathrm{XY}$ significantly more often among VO-languages than among OV languages if and only if $\mathrm{X}$ is a head and $\mathrm{Y}$ is a complement.

The validity of this observation is predicted by the relator principle since a second relatum is always a complement of the relator. However, Dryer rejected the HCT because of correlation pairs such as verb-PP, adjective-Standard of comparison and noun-relative clause, in which the second element is not subcategorized for by the first (i.e. the object patterner is not a complement). The problem is that Dryer does not recognize the relator here and fails to take into account the first relatum. This can be illustrated by the order of noun and relative clause. The relativizer is a relator here. It is placed iconically between its first relatum (the nucleus) and its complement or second relatum (the head of the relative clause). The other problematic constructions can be treated along the same lines. The pair VPP should be split up into Verb (1st relatum) - preposition (relator) - Noun (second relatum). Comparison is encoded in a range of different ways in the languages of the world, but most European languages have a (typologically marginal) comparative particle. This particle (than in English) is a relator, the so-called standard of comparison being its second relatum (or complement). The first relatum is the comparee.

Thus, it turns out that the Head-Complement Theory can be remedied if one looks at the right constructions, taking into account the iconic order of the relator constructions: 1st relatum - relator $2^{\text {nd }}$ relatum. 


\title{
RUSSIAN: ACCUSATIVE OR ACTIVE?
}

\author{
ALEKSEJ MIXAJLOVIČ LAVRENT'EV \\ Institute for philology, Siberian Branch of Russian Academy of Science \\ Department of Russian language in Siberian \\ Novosibirsk
}

It is generally believed that all modern European languages are basically accusative. This seems to be evident for such languages as Latin (with a clear opposition of the markers $-s$ for nominative and $-m$ accusative singular) or modern English (with its rigid SVO word order). More complicated is the case of the modern Russian. "Classical" accusative constructions can be found there in the singular of $-a$ nouns and feminine adjectives, but in all other morphological types (75-80\% of occurrences) the construction is different: the "accusative" has the form of nominative for inanimate nouns, and the form of genitive for personal pronouns and animate nouns. According to traditional Russian grammars, the word order (generally pragmatic in Russian) becomes grammatical if the case markers do not permit to distinguish between the subject and the object. However, counter-examples can easily be found in sentences with rhematic subject (e.g. answers to "Who..." questions).

In other words, in a two-actant action sentence the marked "objective" form is only required for an animate Patient, whose actual inactivity conflicts with its potential activity. This shows the importance of the category of animacy (or activity) for the Russian morphosyntax and evokes immediately the idea of the active language type.

Actually, two different approaches to the definition of this language type are found in literature. The first approach is purely syntactic (Kibrik 1992; Lazard 1998). The active (or "dual") type is defined as the language type where the "Subjective" of one-actant verbs takes the mark of "Agentive" with active verbs (like 'run' or 'swim'), and the mark of "Objective" with inactive verbs (like 'die' or 'fall'). The second approach is "content-oriented" (Klimov 1977). According to this approach the basic feature of "active" languages is the importance for their grammatical structure of expressing an opposition between active and inactive (or animate and inanimate) nouns. It is in the second sense that Russian can be considered to be an "active" language.

In this paper I will argue that Russian morphosyntax is very sensitive to the effective inactivity of animate nouns and vice versa. The Dative case is used to mark actual inactivity of animate semantic subjects. The predicate in these constructions is expressed either by the "impersonal" form ( $3 \mathrm{sg}$, neutral, reflexive) of ordinary verbs, or by a word from a special morphological class of predicates without standard verb markers, called the "category of state" in some traditional grammars (Vinogradov 1947). Inanimate Agents tend to be presented by form of Instrumental (the verb taking the impersonal form, as in the previous case). Generally speaking, the "impersonal" verb forms and the "category of state" may be interpreted as a special class of "inactive" verbs. The real Agent in such constructions seems to be an unnamed natural force.

Should this hypothesis on the presence of the "active" strategy in Russian morphosyntax be adopted, the question is what caused the Russian language to develop this strategy. The answer to it would require extensive investigations based on corpora of Old Russian texts and the history of nonIndo-European languages that were in contact with Russian. However, as a primary hypothesis, the influence of old Finno-Ugrian languages can be assumed.

\section{REFERENCES}

KIBRIK A. E. 1992. Ocherki po obshchim i prikladnym voprosam jazykoznanija: universal'noe, tipovoe i spetsifichnoe v jazyke. Moscow: Izddatel'stvo Moskovskogo universiteta.

KLIMOV G. A. 1977. Tipologija jiazykov aktivnogo stroja. Moscow: Nauka.

LAZARD G. 1994. L'actance. Paris: PUF.

VINOGRADOV V. V. 1947. Russkii jazyk: grammaticheskoe uchenie o slove. Moscow - Leningrad: Uchpedgiz. 


\title{
ARGUMENT STRUCTURE AND (A)TELICITY: EVIDENCE FROM KARACHAY-BALKAR
}

\author{
EKATERINA LJUTIKOVA \\ Moscow State University
}

PROBLEM. There is a number of common assumptions about the relation between argument structure and (a)telicity. One of them, adopted within compositional theories of aspect (Verkuyl 1993, 1999; Krifka 1989, 1992, 1998), is that telicity of verbal predicates is determined, under appropriate conditions, by properties of the Patient. In particular, under Krifka's analysis, quantized internal arguments yield telic verbal predicates while cumulative arguments contribute to the atelic interpretation provided that they stand in incremental relation to the event denoted by the predicate. Thus, eat an/the apple and is telic (quantized) as an/the apple is quantized whereas eat apples is atelic (cumulative) since apples is cumulative.

In this paper, I will argue that in Karachay-Balkar (and presumably, in other Turkic languages as well) atelicity can come from two different sources: incremental change associated with the $\mathrm{Pa}-$ tient and activity performed by the Agent.

DATA. First, in Karachay-Balkar, there are result verbs (as opposed to manner verbs, see Rappaport Hovav \& Levin 1998, Ramchand 2003) which, unlike their English counterparts, do not exclude atelic interpretation:

(1) fatima xaly-ny zyrt-ty.

Fatima thread-ACC tear-PST

1. Fatima tore a thread (in 5 minutes) $\{$ telic $\}$

2. lit. Fatima tore a thread (for 5 minutes) \{atelic\}

('Fatima spent 5 minutes attempting to tear a thread')

Secondly, quantized arguments standing in incremental relation to events can yield both telic and atelic interpretations, as represented in (2):

(2) alim baxca-sy-n sUr-gen-di.

Alim kitchen.garden plough-PST-3:SG

1. Alim ploughed the kitchen garden (in two hours) \{telic\}.

2. Alim ploughed the kitchen garden (for two hours) \{atelic\}.

('Alim spent two hours ploughing the field')

Intuitively, it might seem that what happens in (1) and (2) is the same. In (1), as attempts at tearing a thread advance, at some moment the thread would have been torn, but the agent's activity stops before this moment is reached. In (2), as the ploughing advances, at some moment the garden would have been ploughed to completion, but the process terminates earlier, and only a part of the garden has been ploughed. If it had been the case, both (1) and (2) could have received a unified account, for instance, in terms of Koenig \& Muansuwan's (2001) semi-perfectivity.

However, (1) and (2) are not alike as to their aspectual properties. In (3), the passive counterpart of (1), the atelic interpretation disappears, while in (4), the passive counterpart of (2), it survives:

(3) xaly zyrt-y-1-dy. thread tear-ST-PASS-PST

1. The thread has been torn (in two minutes) \{telic\}.

2. lit. *The thread has been torn (for two minutes) \{atelic\}

('the thread was about to tear for five minutes')

(4) baxca sUr-U-1-du.

kitchen garden plough-ST-PASS-PST

1. The kitchen garden has been ploughed (in two hours) \{telic\}.

2. lit. The kitchen garden has been ploughed (for two hours ) \{atelic\}.

('the kitchen garden underwent the process of being ploughed that lasted for two hours') 
ANALYSIS. To account for these data, we propose that (1) and (2) represent two essentially different sources of atelicity: whereas in (1) atelicity emerges trough the Agent's activity that causes change of state of the internal argument, in (2) it is bound to the material extent of the Patient itself.

Consider result verbs like 'tear' in (1). Assuming, with Rappaport Hovav \& Levin 1998 (who rely heavily on Dowty 1979), the decompositional analysis of such verbs, one can suggest that they must be decomposed into two subevents, a causing subevent and a resultant state. For (1), existentially binding the state variable at some level of representation builds the property of events which cause the emergence of state of being torn:

(5) $\|$ Fatima tear a thread $\|=\lambda \mathrm{e} \exists \mathrm{s}$ [tear' (e) \& Agent (Fatima, e) \& cause (e, s) \& become [torn (s)] \& Holder (thread, s)]

Note that the event predicate in (5) is quantized: it does not hold for proper parts of e, correctly representing the fact that if one performs less activity than needed to tear a thread the resulting state does not come into existence. For this reason, a shift from events which are in the extension of the predicate in (5) to their parts is exactly what we need to capture the atelic reading in (1) which signals that unsuccessful attempt of tearing a thread occurred:

(6) $\|$ Fatima tear a thread $\|=\lambda \mathrm{e} \exists \mathrm{e}^{\prime} \exists \mathrm{s}\left[\mathrm{e} \leq \mathrm{e}^{\prime} \&\right.$ tear $\left(\mathrm{e}^{\prime}\right) \&$ Agent (Fatima, $\left.\mathrm{e}^{\prime}\right) \&$ cause $\left(\mathrm{e}^{\prime}, \mathrm{s}\right) \&$ become [torn (s)] \& Holder (thread, s)]

$\mathrm{e}$ is not necessarily a proper part of $\mathrm{e}^{\prime}$, so (6) correctly predicts both telic $\left(\mathrm{e}=\mathrm{e}^{\prime}\right)$ and atelic $\left(\mathrm{e}<\mathrm{e}^{\prime}\right)$ readings of (1). Besides, the fact that the latter reading is absent in passive (3) is not unexpected either. Passive sentences disregard a causing subevent associated with the agent, foregrounding the change of state associated with the patient. As it is exactly a causing subevent which is the source of atelicity in (1), this results in an unambiguously telic interpretation of (3).

(6) is derived from (5) by the operator that maps an entity into its parts. As far as event predicates are concerned, this job is normally done by the imperfective/progressive operator (Krifka 1992, Filip 1999). This agrees with what Koenig \& Muansuwan's 2001 suggest for languages like Thai: $\operatorname{Impfv}$ operator is embedded into the lexical representation of accomplishments, thus capturing the fact that they do encode completion of the event.

Manner verbs like 'plough', on the other hand, do not include reference to the resultant state in their lexical representation; whether or not they are telic is determined by reference properties of the internal argument. Accordingly, it is these properties that must be responsible for both readings of (2).

To account for (2), let us assume change in the nominal predicate that allows it to refer to parts of entities in its original extension. This amounts to the claim that the phonologically empty partitive operator PART $=\lambda \mathrm{P} \lambda \mathrm{y} \exists \mathrm{x}[\mathrm{P}(\mathrm{x}) \wedge \mathrm{y} \leq \mathrm{x}]($ Krifka 1992) applies to the nominal predicate in (7) yielding a predicate in (8):

$$
\| \text { baxCa } \|=\text { field } \quad(8) \| \text { baxCa } \|=\lambda x \exists y[\text { field(y) \& } \mathrm{x} \leq \mathrm{y}]
$$

Unlike the predicate field, which is quantized, the predicate $\lambda \mathrm{x} \exists \mathrm{y}$ [field(y) $\& \mathrm{x} \leq \mathrm{y}$ ] is cumulative: if the individual $x$ is a part of the object $y$, and the individual $x^{\prime}$ is a part of $y$, then their sum $x \oplus x^{\prime}$ is also a part of $y$. Due to the fact that the 'field' is the Incremental Theme, its reference properties are mapped into the event denoted by the verbal predicate yielding both telic $(\mathrm{x}=\mathrm{y}$, the whole field has been ploughed) and atelic $(\mathrm{x}<\mathrm{y}$, the part of the field has been ploughed) interpretations. As shift in the denotation happens to the internal argument and affects a corresponding event only indirectly, telicity of predicates like plough a field is not expected to change in passive sentences; cf. (4).

Therefore, in both (1) and (2) the atelic reading results from partitivity, but in considerably different ways: by selecting a portion of the agent's activity which is less then needed to cause change in the internal argument, and by selecting a portion of the Incremental Theme, thus implying that not the whole object has been involved in the event referred to. 


\section{REFERENCES}

Koenig, JeAn-Pierre, and NutTanart Muansuwan. 2001. How to end without ever finishing: Thai semi-perfectivity. Journal of Semantics 17: 2, 147-184

KRIFKA, MANFRED. 1989. Nominal reference, temporal constitution and quantification in event semantics. In Bartsch, R., J. van Benthem, and P. van Emde Boas (eds.) Semantics and contextual expression, 75-115. Dordrecht: Foris.

KRIFKA, MANFRED. 1992. Thematic relations as links between nominal reference and temporal constitution. In Sag, I. A. and A. Szabolsci (eds.), Lexical matters, 29-53. Stanford: CSLI.

KRIFKA, MANFRED. 1998. The origins of telicity. In Rothstein, S. (ed.), Events and Grammar, 197235. Dordrecht: Kluwer Academic Publishers,

LEVIN, Beth, and RAPPAPORT HOVAV, MALKA. 1998. Building verb meanings. In Miriam Butt and Wilhelm Geuder, eds., The Projection of Arguments: Lexical and Compositional Factors, 97134. Stanford: CSLI Publications.

Ramchand, Gillian. 2003. Aktionsart, L-syntax and Selection. To appear in H.J.Verkuyl (ed.), Perspectives on aspect. Kluwer.

VERKUYL, HENK J. 1993. A theory of aspectuality. The interaction between temporal and atemporal structure. Cambridge: Cambridge University Press.

VERKUYL, HENK J. 1999. Aspectual Issues. Studies in Time and Quantity. Stanford, CSLI. 


\title{
EQUIPOLLENT DIFFERENTIAL PARTICIPANT MARKING
}

\author{
ELENA Maslova \& TATIANA NiKitina \\ Fremont, USA
}

This paper examines a special class of differential participant marking (DPM), i.e. of case marking patterns in which the encoding of core participant roles depends on semantic and/or referential properties of NPs (sometimes in addition to other factors). Typological and theoretical accounts of such dependencies have been concerned primarily with a class of DPM patterns that can be referred to as privative, where the presence of an overt role marker is opposed to a form unmarked for participant role. The goal of this paper is to explore the theoretical ramifications of equipollent DPM patterns, in which all competing encoding options involve overt morphological marking.

The empirical core of the paper is formed by two case studies of equipollent DPM from the Paleo-Siberian group of languages: the differential A marking in the Chukotko-Kamchatkan languages and the differential $\mathrm{O}$ marking in the Yukaghir languages. In spite of being diametrically opposed in terms of participant-role semantics of overt case markers, these DPM patterns are very similar in their paradigmatic makeup: in both systems, the competing role-marking forms are synchronically identical and/or diachronically related to the Locative and Instrumental case forms of their respective language families. In each case, the distribution of these marking options lends itself very naturally, with minor adjustments, to a description in terms of the universal animacy/topicality hierarchy (ATH), as established on the basis of cross-linguistic investigations of privative DPM patterns (Silverstein 1976; inter alia). Insofar as privative and equipollent DPM patterns appear to invoke essentially the same clusters of semantic and referential distinctions, it seems plausible to hypothesize that the reason(s) why these distinctions can be relevant for case-marking systems must also have something in common.

In the privative DPM systems, the higher-ranked NPs are more likely to be overtly marked for the $\mathrm{O}$ role and less likely to be marked for the A role; in other words, case marking tends to be confined to those situations where the actual participant role differs from the one expected for the given animacy/topicality value. Such distributions are widely taken to reveal a universal constraint against superfluous structural elements, or, in more general terms, the functional pressure towards economy of expression. This type of explanation cannot directly account for equipollent DMP patterns. In the systems under investigation, it is the Locative-like encoding that is associated with the higher end of $\mathrm{ATH}$, while the Instrumental-like encoding is reserved for its lower end, independently of the participant role (A vs. O) being marked. A preliminary cross-linguistic survey suggests that the same holds true if a Locative-like or an Instrumental-like encoding participates in a privative DPM system. In our view, this strongly supports the need to complement economy-based accounts with the analysis of diachronic routes by which different oblique case markers can enter the domain of A vs. O marking (cf. Garrett 1990 on Instrumental-to-Ergative route via the lower end of ATH in Anatolian and Gorokan). In particular, we hypothesize that locative markers enter this domain through the higher end of ATH, since this development is closely associated with the semantic extension involved in the combination of locative with animate NPs.

\section{REFERENCES}

GARRETT, ANDREW. 1990. The origin of NP split ergativity. Language 66, 261-96.

SilversteIn, MichaEL. 1976. Hierarchy of features and ergativity. In Dixon, R.M.W. (ed.), Grammatical Categories in Australian Languages, 112-71. Canberra: Humanities Press. 


\title{
TYPE-NAMING PREDICATIONS VERSUS EVENTUALITY-DENOTING PREDICATIONS
}

\author{
OLAV MUELLER-REICHAU \\ University of Leipzig, Leipzig
}

Natural language sentences are generally viewed to syntactically consist of a predicate and its arguments, whereby the predicate may correspond either to a primitive lexical item or to a complex expression derived by lexical and/or syntactic rules. It is often claimed that every predicate denotes some sort of eventuality and that the syntactic arguments of the predicate are in a particular way semantically related to the denoted eventuality: every argument is analysed as being associated with a certain semantic role in such a way that the argument expression will be interpreted as denoting a participant playing this semantic role in the respective eventuality. The particular kind of semantic role an argument plays is dependent upon grammatical rules linking syntactic arguments with semantic roles as well as upon the sort of eventuality denoted by the predicate. If the predicate denotes a (dynamic) event, its argument(s) will be associated with the role of one event participant such as 'actor/causer', 'patient/undergoer', 'benefactive' etc. The subject of (1) denotes an individual participating in the give-a-talk event as an actor:

(1) The linguist from India is giving a talk

If the predicate does not denote an event, but rather a state, then the semantic role played by the argument's denotation is different in nature - labels such as 'holder' or 'bearer' have been suggested to characterise the "participant of a state", as in (2) '1:

(2) The linguist from India is an invited speaker

The present paper aims at showing that there are natural language sentences which it is not reasonable to think of as denoting eventualities at all - such sentences do neither denote events, nor states. The claim is that categorising sentences such as (3) and taxonomy sentences such as (4) do not denote eventualities. An alternative semantic treatment will be outlined.

(3) The linguist from India is a phonologist

(4) Phonologists are linguists

The subject of a taxonomy sentence like (4), to begin with, names an object type, the predicate nominal names a second object type and the sentence as a whole reports on an "underlying map" (Macnamara et al. 1994) from the former type to the latter type: (4) states that every possible instance of the type PHONOLOGIST is at the same time an instance of the type LINGUIST. By contrast, the subject of a categorising sentence like (3) denotes an instance of the object type named by the head noun of the subject phrase, the predicate nominal names a second object type and the sentence as a whole states that the referent instantiating the former type at the same time instantiates the latter type: (3) states that there is an instantiation of the type LINGUIST (namely the linguist from India) and that the underlying map from PHONOLOGIST to LINGUIST is relevant in the sense that it can be concluded that the linguist from India is not only an instantiation of the type LINGUIST but even of the (more specific) type PHONOLOGIST.

Thus, predicates of taxonomy sentences and categorising sentences are type-denoting (better: type-naming) rather than particular-denoting. The predicates of (1) and (2), by contrast, denote eventualities, i.e. particulars.

The syntactic argument of a type-naming predicate must somehow be semantically related to the type. Otherwise the semantic composition would fail. For taxonomy sentences this is straighfor-

\footnotetext{
1 Note, by the way, that so-called "dynamic states" (Bach 1986) denoted by verbal predicates like sit, lie, sleep etc. go with events rather than states.
} 
ward since the subject itself is purely type-naming. Little as the formulation buys, one could say that the denotation of the subject of a taxonomy sentence plays the role of a 'subtype' of the type denoted by the predicate. For categorising sentences with particular-denoting subjects the situation is more interesting. In order to identify the relation among types in these cases, we must pick up an argument made in Macnamara et al. 1994 (see also Xu 1997, Carey \& Xu 1999). According to these authors, reference to particulars always must be accompanied by the specification of a type. "[P] eople do not have conceptual access to bare particulars, or attribute-free individuals" (Xu 1997). On this view, every referring expression is by necessity typed (even proper names!) 2. Adopting this argument, one could say that the subject of a categorising sentence denotes an instantiation of the type it is typed with, whereby this type plays the role of a 'supertype' of the type named by the predicate.

This view complicates (in a welcome way) the semantic analysis of state-denoting sentences like (2). We say that the subject denotes an instantiation of the object type LINGUIST (furthermore characterised as being from India), the predicate nominal denotes an instantiation of the object type INVITED SPEAKER, the predicate nominal together with the copula forms the predicate-as-such denoting a state and the subject referent participates in this state as a 'holder'. At least, eventdenoting sentences such as (1) can be characterised as follows: The subject denotes an instantiation of the object type LINGUIST (furthermore characterised as being from India), the predicate denotes an instantiation of the event type GIVE A TALK (i.e. denotes an event) and the denotation of the subject participates in the event denoted by the predicate as an 'actor'.

In sum, in order to adequately capture the semantic properties of taxonomy and categorising sentences, it is proposed that every contentful linguistic expression is first of all (=lexically) purely type-naming 3. From such a type-naming expression a particular-denoting expression can be derived. If this is done, the particular-denoting expression will be typed by the type from which it is derived such that the particular-denoting expression refers to instances of the type it is typed with. Two sorts of types are assumed to be linguistically relevant: object types (named by nominals) and event types (named by verbs). Instantiations of object types are objects, instantiations of event types are events. To characterise a predicate as eventuality-denoting (as containing a referential event or state argument in its semantic structure) makes sense only for particular-denoting predicates. Since a denoted eventuality is a necessary prerequisite for a syntactic argument to be semantically related to the predicate via semantic roles such as 'actor', 'undergoer', 'benefactive', 'holder' etc., it must be concluded that the argument of a type-naming predicate cannot be associated with one of these canonical semantic roles.

Thus, the present proposal rejects the often held view that every kind of predication is eventuality denoting. Taxonomy sentences and categorising sentences are not. This implies that not every kind of syntactic argument can be analysed as semantically bearing one of the canonical event-related roles. Drawing a line of demarcation between type-naming predications on the one hand and eventuality-denoting predications on the other hand is not a new idea. Virtually the same has been suggested in Bulygina 1982 for Russian. Bulygina's "qualities" (kaÿestva) correspond to type-level predications, whereas her "appearances" (javlenija) correspond to eventuality-denoting predications.

The present proposal furthermore offers a new semantic analysis for the range of linguistic phenomena discussed in the literature under various lables such as "essential property assignments", "genericity markers", "generic constructions", "individual-level predications" and the like. Turkish verbs marked by the Aorist, Spanish predicates formed by means of the copula ser and Modern Hebrew predications realised along the lines of the so-called +Pron construction are arguably typenaming predications. Indeed, it can be shown that every instance of a Hebrew +Pron sentence can be traced back to either a taxonomy sentence or a categorising sentence. In order to do so, systematic lexical semantic differences between nouns, verbs and adjectives must be taken into account. Only verbs and nouns are sortals and by themselves have the capacity to name object types or event types,

2 These authors critise standard Formal Semantics in its commitment to bare particulars.

3 Ignoring proper names. 
respectively. Adjectival descriptions are non-sortal descriptions which must be conceptually enriched in an accommodation process in order to supply the required type (see Mueller-Reichau 2003).

\section{REFERENCES}

BACH, E. 1986. The Algebra of Events. Linguistics and Philosophy 9, 5-16.

BULYGINA, T.V. 1982. K postroeniju tipologii predikatov v russkom jazyke. In O.N. Seliverstova (ed.), Semantiÿeskie tipy predikatov, 7-85. Moskva: Nauka.

CAREY, S., and XU, F. (1999): Sortals and Kinds: An Appreciation of John Macnamara. R. Jackendoff, P. Bloom, and K. Wynn (eds.), Language, Logic, and Concepts, 311-335. MIT Press.

Macnamara, J., Reyes, G., and La Palme Reyes, M. 1994. Reference, Kinds, and Predicates. J. Macnamara, and G. Reyes (eds.), The Logical Foundations of Cognition, 91-143. Oxford: OUP.

MUELLER-ReichAU, O. 2003. Hebrew copula-predicative constructions. Implications for a general theory of linguistic meanings. Ms.

XU, F. 1997. From Lot's Wife to a Pillar of Salt: Evidence that Physical Object is a Sortal Concept. Mind and Language 12: 3/4, 365-392. 


\title{
SYNTACTIC RELATIONSHIP AREAS IN SOME LANGUAGES OF EUROPE, CENTRAL AND NORTH ASIA: A COMPARATIVE TYPOLOGICAL SKETCH
}

\author{
SHAMIL NAFIQOFF \\ Russian Academy of Science, Institute for History, Language, and Literature, Ufa
}

The geographical region in question is covered by various languages of two superfamilies the Boreal sive Nostratic and the Palaeo-Euroasiatic sive Sino-Caucasian.

From the viewpoint of syntactic typology the Nostratic languages belong to the Nominative or Accusative type while the Sino-Caucasian languages often display features of the Ergative type.

Yet from an historical, diachronic viewpoint certain language families from the Boreal stock reveal their Ergative past. This may be exemplified by the Indo-European languages (Gamkrelidze, Ivanov 1984 and other sources).

The Sino-Caucasian idioms are justly considered to be predecessors of their evolutionally younger Boreal congeners (J. Kerns 1994 and other sources).'

Several major syntactic principles characterize the Nostratic languages continuum:

a) Modifier before its Head or $\mathrm{A} \leftarrow \mathrm{B}$ (left branching);

b) The SOV word order in the majority of the superfamily;

c) The dependant Genitive position in a phrase;

d) Measure of analytical and syntactic constructions;

e) Measure of parataxis $v s$ hypotaxis in the sentence structure of a given language.

A handful of languages in the areas traditionally escape the hard-and-fast lines of the mainstream taxonomy. Far west we have the Basque which falls within the West Caucasian languages' syntactical pattern of Head before Adjunct or B $\rightarrow$ A (Trombetti; 1925), that is attributive adjectives are postnominal there; the same thing is in the Eskimo idiom, Far NE Asia.

In the Far Eastern Ainu the word order is SOV (Batchelor 1905) as much as in the UraloAltaic and other East Nostratic languages.

On the border of Europe and Asia, in the Caucasus area all the vernacular languages tend to be SOV and to place the modifier before the head of grammatical structures (cf. Klimov, 1969: 40, 52). In the Tibeto-Burman language group of the Sinitic family the SOV sentence pattern is also observed as in the Tanghut language, for instance.

The sentence word order regarded diachronically is also known to be changeable. Many IndoEuropean languages at present feature the SVO pattern (Slavonic, Germanic, etc.) but the PIE was predominantly SOV (Lehmann 1972). "Though English is now a VO language, it still retains some features reminiscent of prehistoric SOV origin" (Kerns, op.cit.: 162).

In the Afroasiatic stock one can also come across relics of the earlier SOV syntax (Kerns, op.cit:: 168).

In the Syntax of the phrase not a few languages of the areas analyzed are noted for frequent use of the so-called Serial verbs. Take Bengali ura 'fly' with the ure utha 'to take to wing' i.e. 'to soar flying'. There a great similarity in employing such verbs in the Indo-Aryan and Dravidian languages, on the one hand, and in Turkic and Tajik, on the other. In this respect the Dravidian sentence structure is congruent since the law Rectum ante regens is observed in the idioms of the Dravidian area which historically had been located close to Central Asia.

Another peculiar syntactic feature of the discussed languages is frequent use of the so-called Echo-words or twin(ned) words of the type seen in Georgian are mare 'here and there', Turkish et met 'meat and flesh' and so on (Trombetti 1923: 619).

In many a language of the Boreal and Sino-Caucasian macrofamilies the relative Subordinate clauses are employed with no relative pronouns or any relational words in general. Specimens of this particular syntactic phenomenon can be cited from as diverse languages as Turkic and North East Caucasian like Chechen, etc. (Desheriev 1959: 272) 
Such is a brief sketch of the syntactic relationship areas in certain language families and idioms of Europe, Central and Northern Asia (for more see such sources as Kozinski 1995: 130-132, as well as Kibrik 1993, Comrie 2000 and so forth).

\section{REFERENCES}

BATCHELOR, J. 1905. An Ainu-English-Japanese Dictionary. Tokyo.

COMRIE, B. 2000. Jazyk i doistorija: k mnogodistsiplinarnomu podkhodu. Voprosy jazykoznanija 5, 28-31.

DESHERIEV, Yu. 1959. Chechenski jazyk. Mladopis mennyje jazyki narodov SSSR. Moskva - Leningrad.

T. GAMKRELIDZE, T. \& V. Ivanov. 1984. Aktivnaja tipologija praindoevropejskogo jazyka. Izvestija AN, Serija literatury i jazyka 1.

KIBRIK, A. 1993. Ocherki po obshchim i prikladnym voprosam jazykoznanija. Moskva: Izd-vo MGU. KLIMOV, G. 1969. Tipologicheskije issledovanija v SSSR. Moskva: Nauka.

KOZINSKI, I. 1995. Tri zametki po tipologii. Voprosy jazykoznanija 1.

J. KERNS., and A. Bombhard. 1994. The Nostratic Macrofamily: a Study in distant linguistic relationship. Berlin, N.Y.

LEHMANN, W. 1972. Historical Linguistics.

TROMBETTI, A. 1923 Elementi di glottologia II Bologna.

TrombetTI, A. 1925. Le origini della lingua basca. Bologna. 


\section{IDENTIFYING THE HEAD IN TOPONYMIC CONSTRUCTIONS}

\section{DENIS PAPERNO}

0. THE NOTION OF A TOPONYMIC CONSTRUCTION. In this paper, I call two nouns or noun phrases a toponymic construction if the following is true:

- one of them (A) is a toponym;

- the other one (B) specifies the class of geographical object to which A belongs;

- A and B are within the same noun phrase (we omit some technical details here);

- the fact that $\mathrm{A}$ is the name for $\mathrm{B}$ is not stated in the noun phrase that contains them.

We'll refer to the element that specifies the class of geographical object (B) as the generic component.

Accordingly, the city of Moscow, New York State and Lake Michigan are toponymic constructions (although it may be argued that the last two are proper names). The following expressions are not: Moscow, New York, city, the state, beautiful country, this wonderful Moscow, New York is big (lack of one component); Everest is a mountain, this city is called Kyiv (the components are not in the same NP); and the village named Ouassadougou (the naming relation is stated explicitly).

In many of the world's languages, the syntactic relationship between the components of toponymic constructions is of the same type as in some of the language's possessive constructions. The toponymic constructions that show the same syntactic properties as possessive phrases may be called genitive toponymic constructions, as opposed to appositive toponymic constructions.

A genitive toponymic construction can be marked in a number of ways, e. g. with a preposition (Spanish ciudad de Madrid 'the city of Madrid'), an izafet marker (Persian shahr-e Tehran 'Tehran city'), a genitive case marker (Finnish Helsingi-n kaupunki 'the city of Helsinki'), a possessivity marker (Hungarian Moszkva varos-a 'Moscow city'), a possessive adjective suffix (Old Church Slavonic гора елеоньска), or simply null (Komi Ухта кар 'Ukhta city', which shows the same syntactic properties as Вася керка 'Vasya's house').

1. IDENTIFYING THE HEAD OF THE PHRASE. It appears that within genitive toponymic constructions, the generic component is always the head of the noun phrase, just as it is in the corresponding possessive construction, e.g. the city of Moscow and the father of Mary. For appositive constructions this issue is not so clear.

To deal with this, we make the following assumptions: 1) one of the components (the generic or proper term) is the head of the phrase; 2) the construction is endocentric (that is, the dependent component can be omitted without affecting the grammaticality of the sentence).

The omission test resolves the issue in most cases and identifies the generic component as the head of the phrase. It resists being omitted for a number of reasons:

(1) the generic component may control the agreement of the noun phrase as a whole (Serbo-

Croatian Grad $[M]$ Sarajevo $[N]$ je lijep $[M]$ / Sarajevo je lijepo $[N]$

'Sarajevo city/ Sarajevo is beautiful.');

(2) the generic component, unlike the toponym, may co-occur with the article (Afrikaans $E k$ woon in die dorp Stellenbosch / in Stellenbosch

'I live in Stellenbosch village.' / 'in Stellenbosch.');

(3) only the generic component, not the toponym, takes the article or case affixes required by the noun phrase (Albanian ${ }^{1}$ qytet-i [river-DEF] Elbasan

'Elbasan river' / Elbasan-i [Elbasan-DEF];

Moksha Mordva мон качэнь касонь Оияду веле-са [LOC] / Оияду-са [LOC]

'I was born and grew up in Achadovo village.' / 'in Achadovo.')

I am aware of only three cases where the head is the toponym.

\footnotetext{
${ }^{1}$ Plank 2003: 34.
} 
The first example is an English toponymic construction where the generic component is preceded by the toponym. Other than in established proper names (like New York City), the distribution of this construction is restricted to the names of states (only in order to disambiguate the context, e.g. "Did you see the White House when you were in Washington?" - "I was in Washington state, not the city." Cansas state is also attested, but not *California state), cities (e.g. San Francisco city, which is attested, though some speakers find it strange) and some others (e.g. Hudson river), where the omission of the toponym leads to ungrammaticality unless the article is inserted: It's unusual to see elephants in Washington city/ in the city/ *in the Washington city. Note that within other toponymic constructions that English is rich with the article is necessary: Hudson river, Boston city, but the river Hudson, the city of Boston (here the generic component is the head of the phrase).

Another example is taken from Adygh ${ }^{2}$, where the generic component has a special case marking: (Псыхъо-у [river-ADV]) Москва мычыжжьэу щыл 'Moscow (river) is not far.' / Псыхъо мычыжь-эу щыыI 'River is not far.'

The third example is provided by modern Chinese, where special lexemes (not allowed elsewhere) are used within a toponymic construction: chengshi 'city' / Taipei (*cheng)shi 'Taipei city.'

Our assumptions are not sufficient to identify the head of appositive toponymic constructions in Spanish and Portuguese. In these languages substantives don't have morphologically marked case; both toponyms and generic components require an article (as all common nouns do); the gender of the components of the appositive construction is always the same (Spanish estoi en el [M] lago [M] Titicaca [M] / en el Titicaca / en el lago 'I'm at Titicaca lake.' / 'at Titicaca.' / 'at the lake.') The examples from these languages seem ambiguous.

2. THE ORDER OF THE COMPONENTS. Let's set aside for the moment the non-productive constructions that may be regarded as proper names, attributed to specific toponyms, e.g. the Russian Москва-река and the English Lake Michigan. An interesting observation can be made regarding toponymic constructions, both genitive and appositive. In left-branching ("postpositional") languages the head's unmarked $^{3}$ position is to the right of the dependent component, while in right-branching ("prepositional") languages it is to its left. The ambiguous data of Spanish and Portuguese don't contradict this generalization. The generalization holds, no matter which of the components (the toponym or the generic component) is the head.

The toponymic constructions are similar to pre- and postpositional phrases and possessive phrases in one other respect: the components of toponymic constructions can be separated with the same set of elements that the corresponding possessive constructions can be separated with: the city of Boston, like the mother of Mary; the Russian, poetically marked город прекрасный Москва 'the beautiful city of Moscow' like город прекрасный Петра 'the beautiful city of Peter.'

In other words, it seems very natural to regard the dependent component of the toponymic construction as filling a complement position of the head. This position corresponds to the generic component's semantic valence for a toponym (in most cases) or that of the toponym for a generic component (in several cases). The principles (cognitive, pragmatic, etc.) governing the choice of one or another syntactic (and semantic) structure for toponymic expressions in a given language is a separate issue that I leave without analysis for now.

\section{REFERENCE}

PLANK, FRANS. 2003. Double articulation. In Noun Phrase Structure in the Languages of Europe. Berlin-NY. 337-396.

\footnotetext{
${ }^{2}$ The Adygh data were kindly provided by Yu. Lander.

${ }^{3}$ Some languages allow the reverse order as well (Avar МахІачхъала шагъар/ шагьар МахІачхъала' 'the city of Makhachkala'); such languages are not numerous.
} 


\title{
CLAUSE STRUCTURE IN THE RUSSIAN-CHINESE PIDGIN
}

\author{
ELENA V. PEREKHVALSKAYA \\ St. Peterburg State University, Department of General linguistics
}

1. Clause Structure IN THE RUSSIAN-ChineSE PIDGin. The pidgin in question is known as the Kyachta language, the Maimachin idiom, the Far East Pidgin Russian or the Siberian pidgin, yet the most usual name is the Russian-Chinese pidgin (RChP). This name presupposes that the main contributing languages in the formation of this pidgin were Russian and Chinese. Was it really so? Certain features in the clause structure may contribute to the solving of this problem.

The RChP in its basilect form practically lacks the inflectional morphology which contrasts with a very complicated morphological structure of the lexifier. In the Russian language the clausal structure is overtly expressed by the system of grammatical cases and prepositions and to a lesser extent by the word order. The RChP lost both grammatical case and prepositions so the clausal arguments are interpreted mainly by the general semantic context:

Agent-Patient

$\begin{array}{llll}\text { (1) Eta l'udi } & \text { patom } & \text { dzimli } & \text { kapadzi }(\mathrm{K}) \\ \text { This person } & \text { then } & \text { ground } & \text { dig }\end{array}$ 'Then this person dug the ground.'

(2) Hedzu -- liba kupi-la (Sh)

Hedzu--- fish buy-PAST

'Hedzu bought fish'

\section{Other arguments}

Location

(3) Sam ---gorod pashol jivo.' (FEP) Himself-city went $3 \mathrm{Sg}$.

'He himself went to the city'

(4) My prijehal kareisa fanza (Tz)

1Pl came Korean house

Instrument

'We came to the Korean houses.'

(5) Buldozera rovno delaj (K)

bulldozer even make

' $<$ they $>$ leveled the ground with the help of bulldozer.'

All arguments are identically expressed by noun phrases which may consist of a noun with or without dependant words (demonstratives or adjectives) or a personal pronoun. Thus, we rely mostly on the semantic role of the argument in order to determine its grammatical role in the clause. The Pidgin has only the active voice so the semantic role of agent always corresponds to the grammatical relation of the subject and the semantic role of patient corresponds to the grammatical relation of the direct object, $\operatorname{cf}(1)$ and (2).

Thus the actual interpretation of the grammatical structure of the clause is mainly based on the general semantic context. It may also be interpreted by the word order.

2. WORD ORDER. As has often been pointed out the RChP tends to have the SOV word order. If the clause contains both the Object and the Benefactive or other arguments, the Object occupies the place nearer to the Verb.

(6) evó dúmaj majá jevó čéna daváj (Ja)

$3 \mathrm{Sg}$ think $1 \mathrm{Sg} 3 \mathrm{Sg}$ price give

'He thinks that I give him the $<$ real $>$ price.' 
(7) Nada lipahoza kater cho vazi-la (K)

Necessary lumber.company cutter what carry-PAST

'It was necessary to carry things to the lumber company by motor boat.'

All the secondary arguments (Location, Instrument, Means of transportation etc), with the exception of the adjunct of Time tend to occupy the position between S and V:

Eto kotory l'udi kalotsa lazi-l (K)
This which person well climb-PAST
'That man who climbed into the well'

As RChP was always an oral auxiliary language it probably never had any norm, even a norm "de facto". Therefore the grammatical rules were often violated and the word order was never really strict. Cf. (3), (4), (17). Without the strict word order rule the task of argument interpretation of a clause becomes almost impossible taking into account the lack of both inflectional morphology and prepositions. The last resort here would be to use the general context of the expression.

3. CONTEXT INTERPRETATION. The exact interpretation of a single clause is impossible in RChP. In fact, the expression kaban taskaj (wild.pig drag) would be probably understood as "wild pigs usually drag (steal)", because the word taskaj is highly polysemantic in the pidgin. It may mean "pull, drag, steal, carry". But the wider context makes it possible to figure out the real meaning of this clause: " $<$ we had $>$ to carry $<$ carcasses of $>$ wild pigs $<$ to the riverbank $>$ ".

(9) Isho kada kasa stali, kaban taskaj, panty

So when sand.bar stop wild.pig drag antlers

pili chivo, a dom dal'oko (FEP)

saw something but house far

'When we stopped at sand bars, it was necessary to carry $<$ carcasses of $>$ wild pigs $<$ to the boat $>$, to saw off antlers $<$ of elks $>$, but the house was far away $<$ and it was necessary to bring all that home $>$.'

In order to make the argument structure more transparent the whole situation is often cut into minor situations so that each predicate would have only one or at the most two arguments.

(10) Hedzu liba kupi-la, eta liba pamilaj netu, eta vada

Hedzu fush buy-PAST this fish die NEG this water puskaj-la, eta liba ubizha-la (Sh)

let-PAST this fish escape-PAST

'Hedzu bought a fish $<$ it was alive and Hedzu put it into the water $<$ river $>$, so the fish went away.'

(11) Tak hudo hodi, ego mogu strel'aj. Ego dumaj, so badwalk $3 \mathrm{Sg}$ can shoot $3 \mathrm{Sg}$ think

nasha chushka est' (Ar).

1Pl pig be

'We shouldn't walk like that, they may shoot taking us for wild pigs'

The segmentation of the text into very simple clauses is a characteristic feature of all variants of the RChP. Practically all the texts available, be it modern recordings, citations in fiction or examples in linguistic articles present this feature.

4. LEXICAL MEANS OF EXPRESSING THE CLAUSE STRUCTURE. At some point of its history the RCHP was expanding. This process was connected with the formation of new grammatical means on the basis of lexical items. The RChP was clearly in the process of forming a class of postpositions. Postpositions are also characteristic for Govorka, the Taimyr Russian-based pidgin. In Govorka the posposition mesto is used to mark different adjuncts. In RChP certain nouns, adjectives and adverbs could also be used as postpositions 


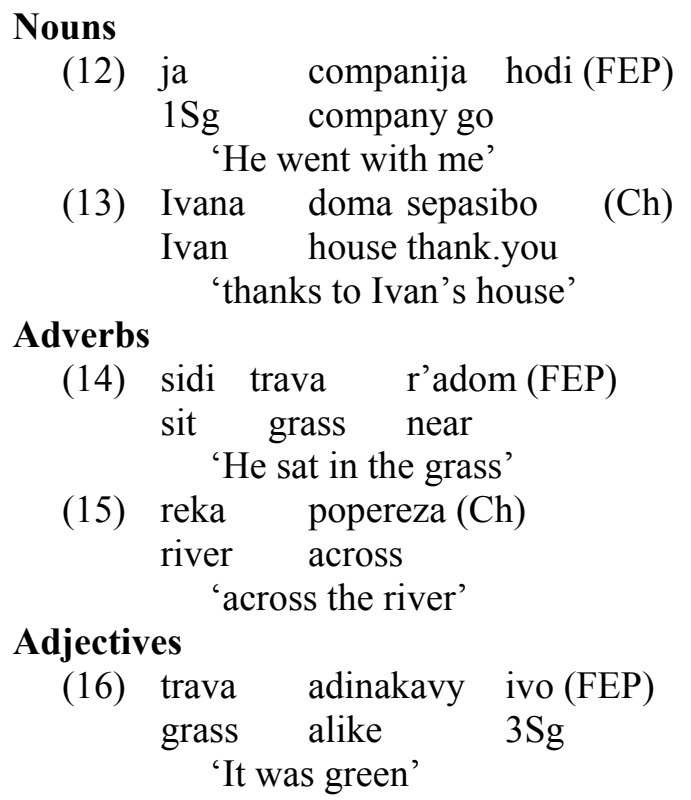

Another model is presented by the use of deictic adverbs which help to define more precisely the meaning of a Locative argument. Such adverbs do not necessarily follow the argument and can be put elsewhere, though they also express a certain tendency of following the argument in question.

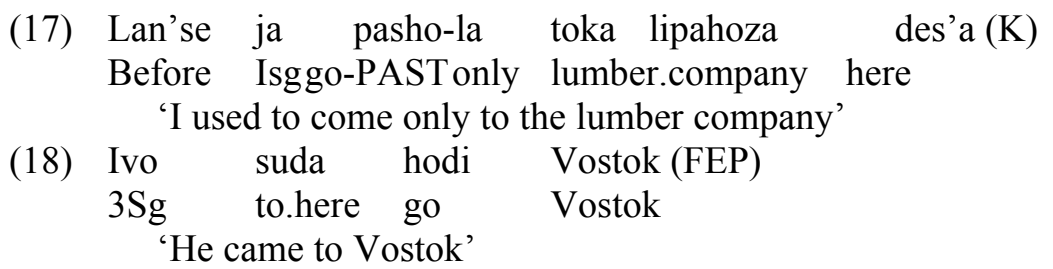

5. CONCLUSION. While expanding the RChP clearly had a tendency to establish the SOV word order, the system of postpositions and the system of deictic adverbs make the locative arguments more precise. The first two features are not characteristic of either the Russian or Chinese languages but are common for languages of the Altaic family which is spread all over Siberia. Native speakers of theses languages often used the RChP for communication with Russians and other Europeans, as it is attested by the sources for the RChP. It seems obvious that this pidgin probably originated in the process of Russian-Aborigine Siberian trade and only after that it began to be used by the Chinese. As J. Nichols pointed out "the contribution of the Chinese ... was not so much the nature of the pidgin as its stability" (J. Nichols, Pidginization and foreign talk: Chinese Pidgin Russian \ Papers from the $4^{\text {th }}$ Int. Conference on historical linguistics, John Benjamins, 1980, 405). The name RussianChinese pidgin seems erroneous and it seems more adequate to speak about the Siberian pidgin formed on the Russian lexical basis in the course of communication with Altaic speaking peoples of Siberia.

\section{SOURCES}

(Ar) ARSEN'EV V. K. 1976. Po Ussurijskomu kraju [Across the Ussury region]. Moscow: Gosgeorgizdat.

(Ch) CHEREPANOv S. I. 1853. Kjahtinskoje kitaiskoje narechije russkogo jazyka [The Kyahta Chinese dialect of the Russian language]. Izdestija II Otd. Imperatorskoj Akademii nauk, 2, 10.

(FEP) Far-East Pidgin recorded by the author in the settlement of Krasnyj Yar (Primorsky area, Russia) in 1985.

(Ja) JABLONSKA, A. 1957. Jezyk mieszany chinsko-rosyjski v Mandzurii [Mixed Chinese-Russian language in Manchuria]. Przeglad Orientalistyczny 21, 157-168. 
(K) Kukan variety recorded by the author in the settlement of Kukan (Amurskaya area, Russia) in 1991.

(Sh) SHPRINTSIN,A. G. 1968. O russko-kitaiskom dialekte na Dal'nem Vostoke [On the RussianChinese dialect in the Far East]. Strany i narody Vostoka 6, 78-85.

$(\mathrm{Tz})$ Tazy variety recorded by the author in the settlement of Mikhailovka (Primorsky kray) in 1991.

(Vr) VRUBEL, S. A. 1931. Russko-kitaiskije jazykovyje skreshchenija [Russian-Chinese language mixing]. Kul'tura i pis'mennost'vostoka 7-8, 131-139. 


\title{
CONTACT-INDUCED CHANGES IN FINNISH ROMANI: PASSIVE VOICE
}

\author{
HELENA PIRTTISAARI \\ University of Helsinki, Department of General Linguistics
}

This paper discusses the language contact between Finnish Romani (Indo-Aryan, with earlier IndoEuropean contact influence) and Finnish (Uralic), with particular attention to the form and function of voice. I intend to show that the coding of the passive voice in Finnish Romani manifests Finnish features, resulting in changes in the argument structure. The paper adopts the theoretical concepts of contact linguistics and the study of language universals. The study is based on a corpus of 147,000 words, compiled mainly by Lars Borin (2001).

The term 'influence' is used as adoption of any elements or features from the contact language. We can define somewhat simplified convergence as the elimination (loss) of non-congruent forms in languages in contact, and interference as the introduction of new forms or rules in one language under influence from another (Beniak \& al. 1984-5).

The verbal system of Finnish Romani shows a complex mosaic of archaisms and innovations. As a residue of the late Middle-Indo-Aryan ergativity system, finitized past participles are continuously used in past tense 3SG. At the same time, Finnish influence is manifested in various parts of the verbal system. First, Finnish interference is manifested in the occurrence of Agentless passive and Agent participle, or coding the voice in the past participle. Second, constructions and morphological oppositions not found in Finnish are (gradually) lost. An example of convergence is the loss of the synthetic passive in Finnish Romani. Instead, there are two kinds of analytic passives, formed by combining the copula with the Indic, 'thematic' past participle, or with the Greek, 'athematic' past participle in -men $(<-$ ménos). In what follows, I shall discuss three related phenomena, triggered by Finnish influence, (i) coding of the voice in the two participle suffixes, (ii) Agent participle, and (iii) Agentless passive.

Unlike most other dialects that continuously use active past participles in the 3SG past tense (cf. Matras 1995), the finitization of participles is not restricted to intransitive verbs in Finnish Romani, even the past participles of transitive verbs being used actively in the 3SG past tense. The logical Subject of the sentence is then the grammatical one, and the construction is not ergative. Finitized participles can take same arguments as finite verb forms; cf. Example (1). Finitized participles no longer show gender agreement with the Subject, as was still the case in the 1930s (see Example (1a)) and not necessarily number agreement because of the influence of colloquial Finnish, consider Examples $(1 b-c)$.

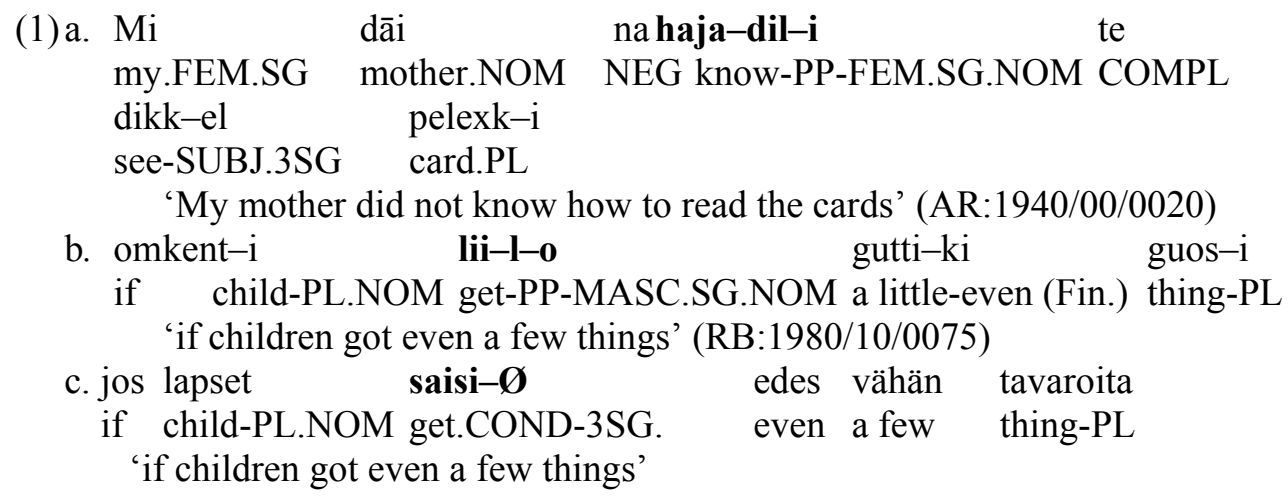

The same tendency can also be noted in other past tense forms. In Finnish Romani the active perfect and pluperfect are formed as compound tenses, the result of Finnish influence, with the copula som/aahhaa 'to be' and the past tense form of the main verb (cf. Vuorela \& Borin 1998). There is double marking of number and person, since these categories are coded both in the auxiliary and in the main verb, as in Example (2). 


$$
\begin{aligned}
& \text { Butvares me s-om aah-t-om mulani } \\
& \text { often I be-PRES.1SG be-PAST-PRES.1SG sad.FEM }
\end{aligned}
$$

This is against the definition of the Indo-European tradition of linguistics that only auxiliaries are inflected in the verbal complex (cf. Ramat 1987). However, the past participle can be used in active function even in compound tenses instead of the inflected form; cf. Example (3a). Since it is even more usual in compound tenses than in the past tense, this could be the first sign of its grammaticalization as the uninflected constituent of the verbal complex, as in Indo-European languages and in Finnish. In Finnish it shows number agreement with the Subject (Example 3c), but in Romani the category number is occasionally lost; consider Example (3b).

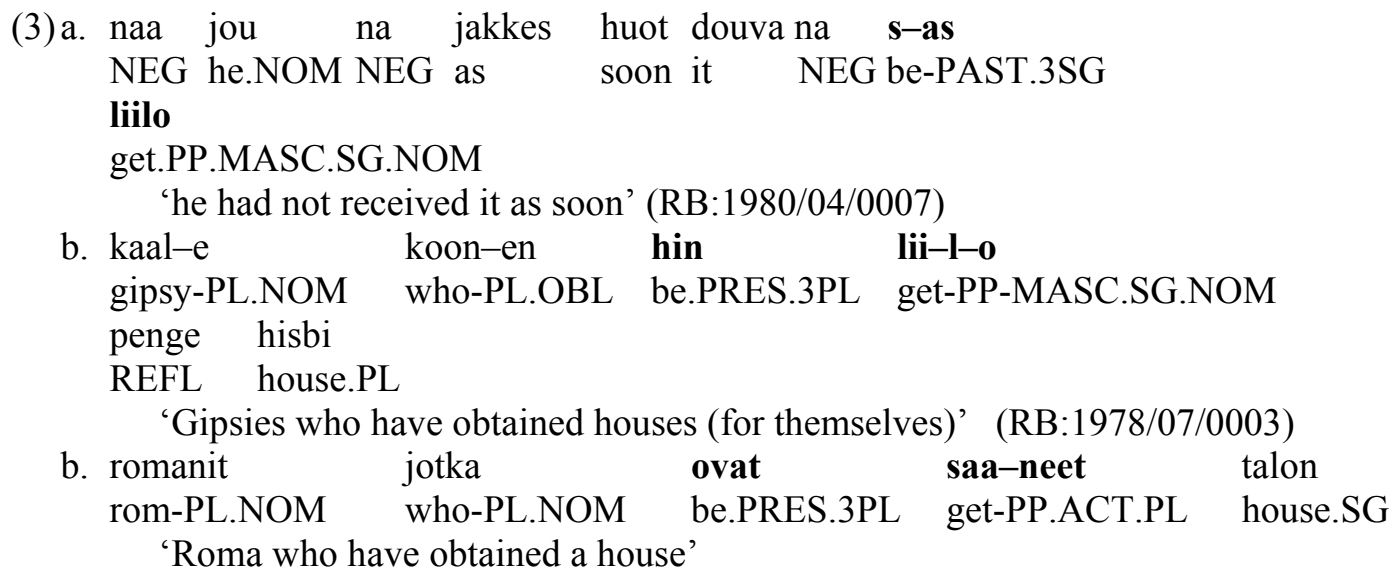

Because the past participle has acquired the aforementioned active functions, it is in accordance with the principle of isomorphism, i.e., the 1:1 -relation of form and function, that its function as the past participle passive is coded in another form. As Bubeník (2000) has noted, the weakening of the opposition between active and passive perfect is an old Indo-Aryan dilemma, and there have been several attempts at its solution. One possible solution in Romani is borrowing the Greek participle suffix men. My corpus suggests that the tendency in Finnish Romani appears to be the coding of the voice in the participle: the active voice in the thematic and the passive in the athematic suffix in transitive verbs, which show interpretative ambiguity - but not in all cases or in every idiolect, since it occurs mostly among speakers born in the 50s and later. For example, the syntagm hin diile is ambiguous between the active and the passive, having two context-dependent interpretations: 1) have given, 2) has/have been given (the 3PL functions as Agentless passive with no agreement in number with the grammatical Subject, cf. below). In the suggested development the thematic participles get the active interpretation, the athematic ones the passive; consider the next Examples:

(4) hin dii-l-e '1. have given 2. has/have been given'

-> (a) hin dii-l-e 'have given'

(b) hin diij-ime 'has/have been given' = innovation, interference

The morphological coding of the voice results in unambiguous alignment between morphology and semantics, i.e., whether the Subject is the Agent or the Patient. This development shows strong Finnish interference, because in Finnish the active and passive voice are coded in different participle suffixes; see Example (5).

(5) a

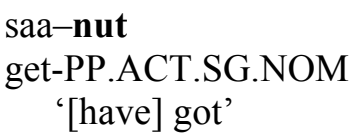

\author{
b. saa-tu \\ get-PP.PASS.SG.NOM \\ '[have been] got'
}

Further, there is asymmetry in the participle patterns over different tense-aspects, with the present passive participle missing in Finnish Romani, which is a cross-linguistically typical phenomenon (cf. Haspelmath 1994). This is shown in Example (6). 
(6) Active

Present rann-ime 'writing'
Past ran-lo 'having written'
Passive

ran-lo $\sim$ rann-imeN 'written'

When the athematic suffix is replacing the thematic one in the passive function, the system of voice is developing towards greater symmetry. However, there are simultaneous tendencies towards greater complexity in other parts of the system, for instance, when the athematic suffix also codes the active present participle.

In what follows, I shall discuss two related phenomena with a specific argument structure. In the written language, four of the five Finnish participles, represented in Example (7), have an equivalent in Finnish Romani. The fifth participle, luke-ma for instance, is labelled as [the second] Perfect participle passive by Haspelmath (1994) and Agent participle in the Finnish tradition of linguistics. To avoid ambiguity, I shall adopt the latter notation.
Active
Passive
Present luke-va 'reading'
Perfect luke-nut 'having read'
lue-tta-va 'readable, to be read' lue-ttu/luke-ma 'read'

(based on Haspelmath 1994:156; but I understand the PRES.PART.PASS as expressing necessity in addition to potentiality)

Finnish Romani does not allow an overt Agent in the passivization (8b), whereas an inanimate Instrumental, marked by case, may occur (8a). The Instrumental cannot be promoted to Subject.

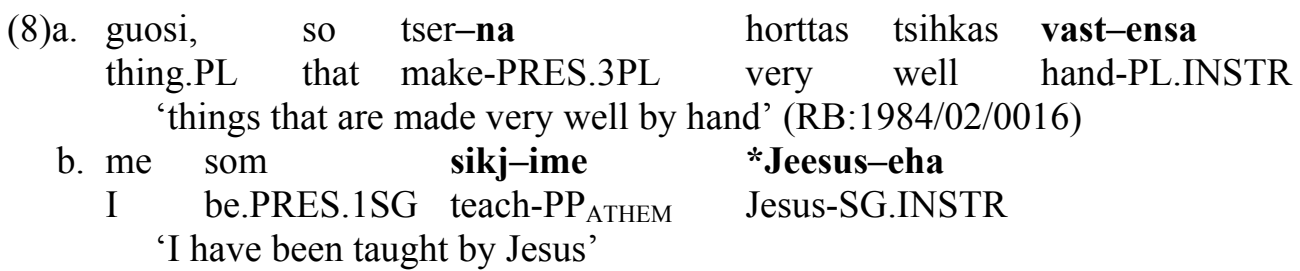

By contrast, the so-called Agent participle demands an overt Agent in the Genitive case. Finnish uses a specific participle form, i.e., the fifth participle for this construction (9b), whereas Finnish Romani uses the athematic participle in -men for the same purpose (9a); contrast (9a) with (8b). It is to be noted that interference features in Finnish Romani are mostly triggered by spoken Finnish but in this case by a written language, since the Agent participle hardly occurs in spoken Finnish.

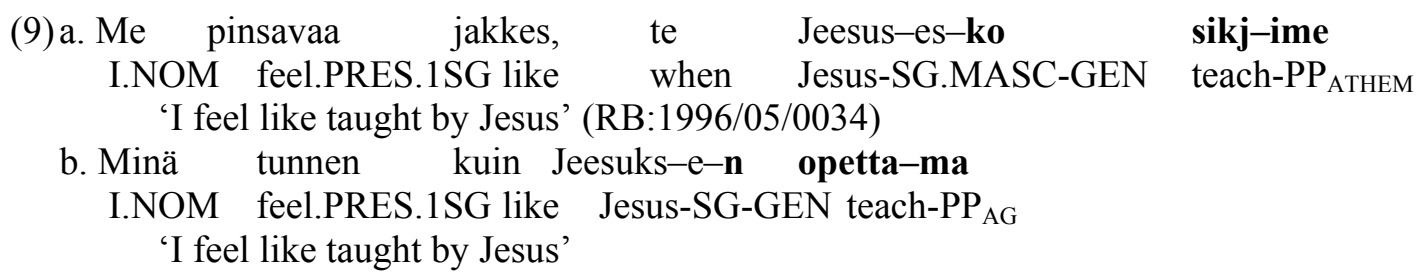

We now turn to the third phenomenon to be discussed in this paper. While Finnish lacks a 'true' passive, it manifests Agentless passives, hence 'PASS'. It is not undisputed whether these are to be considered as passives or as actives with an indefinite Subject (cf. Palmer 1994). They can be treated as 'backgrounding' passives, which can occur without Object promotion (Foley and Van Valin 1984; cf. Palmer 1994). Finnish uses a specific verb form for this purpose (10), whereas Finnish Romani uses the 3PL, which is typical of the world's languages (Keenan 1985) (8a). The use of the Agentless passive has probably extended on the impact of the Finnish pattern, even though the form differs.

$$
\begin{aligned}
& \text { Tavarat, joita tehdä-än } \\
& \text { thing.PL that make-PRES.'PASS' oikein hyvin käsin } \\
& \text { 'things that are made very well by hand' }
\end{aligned}
$$

In colloquial Finnish, the Agentless passive form is used instead of the 1PL (11b). It has been suggested that Finnish Romani uses the 1PL in a similar way, omitting the Agent (11a). 
(11)a.

$$
\begin{array}{ll}
\mathrm{j}-\text {-aha } & \text { toori mark } \\
\text { go-PRES.1.PL } & \text { there marketplace }
\end{array}
$$

'we go/let's go to the marketplace' (Valtonen 1968:145)

b. mennä-än sinne markkinoille

go-'PASS' there market.PL.LOC

'we go/let's go to the marketplace'

To conclude, the verbal morphosyntax of Finnish Romani shows, at least to some extent, Finnish features. Three phenomena triggered by Finnish contact influence were discussed in this paper: (i) there is a functionally motivated tendency to distinguish morphologically between active and passive perfect, resulting in unambiguous grammaticalization of the participant roles, (ii) a passive-like construction with an overt Agent in Genitive case occurs, (iii) 3PL and 1PL are used as an Agentless passive. Only (i) can be regarded as a (partial) simplification of the system.

There is nothing new in that the speakers of Romani use Romani morphology in this way to "copy" the structure of a European contact language (cf. Matras 1995). Structural borrowing is possible wherever languages are in intense contact (Thomason \& Kaufman 1988). The situation becomes more complicated when the great amount of idiosyncrasies is taken into account. This makes the system less regular and less predictable. The assumption of a monolithic linguistic system needs to be questioned, as argued by Vuorela and Borin (1998).

\section{REFERENCES}

BeNIAK, E., R. MOUGEON, and D. VALOIS 1984-1985. Sociolinguistic evidence of a possible case of syntactic convergence in Ontarian French. Journal of the Atlantic Provinces Linguistics Association 6/7, 73-88.

BORIN, LARS. 2001. A Corpus of Written Finnish Romani Texts. http://www.ling.uu.se/lars/pblctns/lrec2-romani.pdf

Bubení, VíT. 2000. Was Proto-Romani an ergative language? In Viktor Elšik \& Yaron Matras (eds.), Grammatical Relations in Romani. The Noun Phrase. CILT 211, 205-227. Benjamins, Amsterdam.

Foley, W. A., and R. D. VAN VALIN 1984. Functional syntax and universal grammar. Cambridge University Press.

Haspelmath, Martin. 1994. Passive Participles across Languages. In Barbara Fox \& Paul Hopper (eds.), Voice: Form and Function. Benjamins, Amsterdam.

KEENAN, EDWARD. 1985. Passive in the world's languages. In Timothy Shopen (ed.), Language typology and syntactic description, 243-281. Cambridge: Cambridge University Press.

MATRAS, YARON. 1995. Verb evidentials and their discourse function in Vlach romani narratives. Yaron Matras (ed.) Romani in Contact. The History, Structure and Sociology of a Language. CILT 126, 95-124. Benjamins, Amsterdam.

PALMER, F. R. 1994. Grammatical roles and relations. Cambridge: Cambridge University Press,

RAMAT, PAOLO. 1987. Introductory Paper. In Martin, Harris \& Paolo Ramat (eds.), Historical development of auxiliaries, 3-19. Berlin: Mouton de Gruyter.

Thomason, SARAh Grey, and Terrence Kaufman. 1988. Language Contact, Creolization and Genetic Linguistics. Berkeley: University of California Press.

VAlTONEN, PERTTI. 1968. Suomen mustalaiskielen kehitys eri aikoina tehtyjen muistiinpanojen valossa. Licentiate's Dissertation. Unpublished. University of Helsinki.

VuORElA, KATRI, and LARS BORIN. 1998. Finnish Romani. In Ó. Corráin, A. \& S. Mac Mathúna (eds.), Minority Languages in Scandinavia, Britain and Ireland. Acta Universitatis Upsaliensis. Studia Celtica Upsaliensia 3, 51-76. Uppsala. 


\title{
SINGLE, DOUBLE OR TRIPLE: WHAT AFFECTS THE NUMBER OF CAUSATIVE MARKERS IN BEZHTA
}

\author{
ALEXANDR PODOBRJAEV \\ Moscow State University
}

This investigation explores the valency-changing phenomena in Bezhta. It is the result of one-week fieldwork in the village of Tliadal (Daghestan, Russia) in August 2003 (MSU linguistic expedition under the direction of K.I. Kazenin, A. E. Kibrik and Ya.G. Testelets). Bezhta (Nakh-Daghestanian, Avar-Andi-Tsez, Tzesic) is an ergative language spoken by less than 7000 people in the Tsunta region of Daghestan.

The morphological causative in Bezhta is formed means of an affix -(i)l, which (under certain circumstances) can be duplicated or even triplicated, which is rather untypical for Daghestanian languages. A few examples are given below:

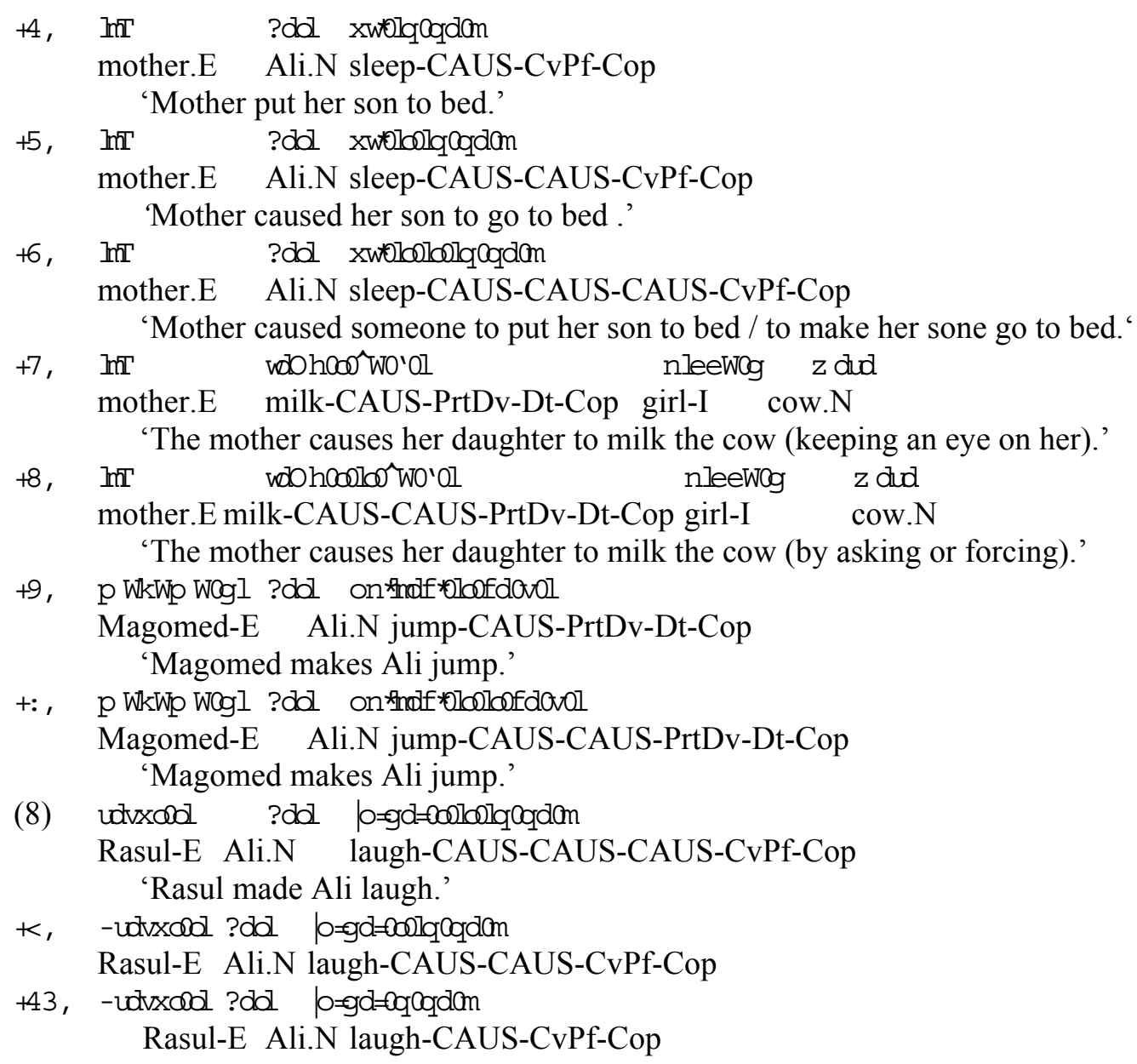

The earlier description of the causative construction in Bezhta was based on the idea that transitive verbs are causativized only by reduplicated or triplicated causative morpheme (tiple causative encoding strong causation) - see [Kibrik, Testelets 1982 ("causatives" by A. Dybo)], which is evidently wrong (see (5)), though it reflects a very strong tendency.

At first glance, double and triple causatives encode the meanings of distant vs. contact causation (1-2), double vs. simple causation $(1,2-3)$ or strong vs. weak causation. In some cases they tend to be meaningless (6-7) (semi-causative in terms of [Kulikov 1993], analyzing the examples of the related Tsez language). What is to be discovered is the constraints on the reiterating causative affix in sentences with different sets of paricipants and semantic background.

The probable solution of the problem is achieved by placing causer and causee both on the scale of agency / activity control. Cognitively, the scale is continual. Language divides it in two axes: 
in the first one the participant is conceptualized as week, in the second one it is conceptualized as strong, these two have a certain intersection (Figure 1). The coplacement of causer and causee on this continuous scale seems to be the only way to predict the number of causative affixes attaching to a verb.

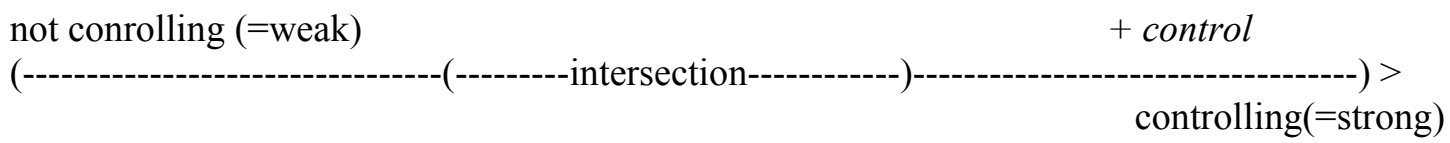

\section{FIGURE 1.}

The basic principles are as follows: if the causer is weak and the causee is as weak or stronger, double causative will occur; if the causee is weak and the causer is as weak or stronger, single causative is observed; if both causer and causee are strong, triple causative. Reduplication of the causative morpheme is the means to mark that the situation is controlled by the causee rather than the causer. This model explains also the presence of "meaningless" second causative, which occurs in the conflict siuations (causer and causee in the intersection).

There is a huge tradition explaning the presence of different causativizing possibilities in language (in our case: single, double and triple causatives). Certain typologically-oriented works (e. g. [Dixon 2000]) are rather close, though not identical, to our views. Dixon describes the set of analogous parameters concerning causer and causee taken separately, but that analysis fails to explain Bezhta data, where the relation between causer and causee is to be measured.

The proposed explanatory model may be useful in the analysis of causative constructions in the other related and non-related languages, especially the facts concerning "semantically empty" markers.

Finally, we should mention that the semantic features involved have some interesting parallels in syntax (e.g. causee case marking).

\section{REFERENCES}

DiXon, R.M.W. 2000. The typology of causatives. In Dixon \& Aikhenvald (eds.), Changing valency. Case studies in transitivity. Cambridge.

KIBRIK, A.E. and TeSTELETS, Ya.G. 1982. Bezhta. Moscow.

KUlikOV, L. 1993. The "second causative": a typological sketch. In Bernard Comrie \& Maria Polinsky (eds.), Causatives and Transitivity. Benjamins. 


\title{
SYNTACTIC AND INFORMATION STRUCTURE OF STATIVE VERB SENTENCES WITH EXPERIENCER NP-S IN KOREAN
}

\author{
ELENA RUDNITSKAYA \\ Institute of Oriental Studies, Language Division, Moscow
}

This paper considers bivalent stative verbs with 'EXP(eperiencer)' and 'TH(eme)'/ 'Patient' arguments in Korean, such as mwusep-ta 'be afraid of' or coh-ta 'like'. Whereas the 'TH' argument of mwusep-ta 'be afraid of' is NOM(inative), the 'EXP' argument can, besides DAT(ive) (1a), be marked TOP(ic) or NOM (1b-c). Such verbs often have a non-stative counterpart (mwusep-ha-ta 'beafraid-of-do') with an ACC(usative) 'TH' object (1d). The 'TH' NP in (1a-c) is not ACC because a stative verb in Korean cannot govern an ACC complement.

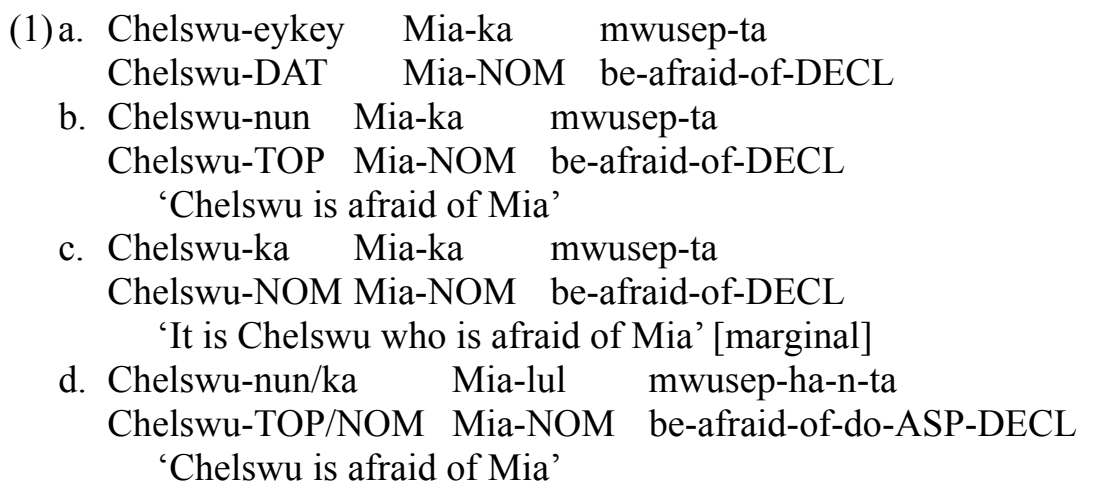

It has been proposed (originally by Heycock and Lee 1989) that the pattern in (1b-c) includes two (syntactic) predications, similar to well-known "double predication" sentences with "two subjects" $(2 \mathrm{a}-\mathrm{b})$. This proposal is mainly based on the NOM-NOM pattern in (1c) and the assumption that a NOM NP is a subject (that is, (1c) has two subjects: Chelswu and Mia). According to Teng 1974 and Heycock 1993, in a sample "double predication" sentence (2a-b), the first TOP/NOM NP (Waikhikhi) is not an argument, but the logical and at the same time the "major" subject of the sentence. The second NOM NP (kyongchi) is the grammatical subject included into the sentential predicate of Waikhikhi: [kyongchi-ka coh-ta] ([NP(NOM)-V]). Waikhikhi and kyongchi-ka coh-ta in (1b-c) form an additional verb-less "syntactic" (and semantic) predication.

Lee and Kim 1988, and Yoon 2003, on the contrary, claim that (1b-c) correspond to only one predication: the 'EXP' NP is the syntactic subject, whereas the 'TH' NP is the syntactic object.

TOP in Japanese/ Korean is a marker of a logical subject rather than of a discourse topic $(\mathrm{Ku}-$ roda 1972), but NOM marks rheme or focus (cf. (2a-b)). In an embedded context, all subjects are $\operatorname{NOM}(2 \mathrm{c})$.

(2)a. Waikhikhi-nun kyongchi-ka coh-ta

Waikiki-TOP landscape-NOM good-DECL

'Waikiki has good landscape'

b. Waikhikhi-ka kyongchi-ka coh-ta

Waikiki-NOM landscape-NOM good-DECL

'It is Waikiki that has good landscape'

c. Na-nun Waikhikhi-ka kyongchi-ka

I-TOP Waikiki-NOM landscape-NOM

coh-ta-ko sayngkakha-n-ta

good-DECL-QUOT think-ASP-DECL

'I think that Waikiki has good landscape'

Based on my data, TOP/NOM sentences $(1 \mathrm{~b}-\mathrm{c})$ have one predication based on the argument structure of bivalent stative verbs with an 'EXP' semantic role (mwusep-ta 'be-afraid-of'). However, the TOP/NOM 'EXP' is grammaticalized as a logical subject of its [NP(NOM, 'TH') - V] sentential 
predicate. This results in the "frozen" information structure of $(1 \mathrm{~b}-\mathrm{c})$ and certain restrictions on the information status of the 'EXP' and the 'TH' NP-s.

In the (1b-c) pattern, the 'EXP' NP always controls honorific verb agreement ( $3 a-b)$; only the 'EXP' NP - 'TH- NP binding relation is possible (4a-b). Thus, agreement and reflexivization tests allow us to conclude that TOP/NOM-NOM sentences contain one predication, based on a bivalent predicate, with the 'EXP' NP as a grammatical subject.

(3) a. Chelswu-nun halape-nim-kkeyse Chelswu-TOP grandfather-HON-NOM.HON mwusew-(*usi)-ta be-afraid-of-(*HON)-DECL

'Chelswu is afraid of the grandfather'

b. Halape-nim-kkeyse Chelswu-ka grandfather-HON-NOM.HON Chelswu-NOM mwusew-usi-ta be-afraid-of-HON-DECL

'The grandfather is afraid of Chelswu'

(4) a. Mia-nun caki-casin-i mwusep-ta Mia-TOP self-self-NOM be-afraid-of-DECL

b. *Caki-casin-nun Mia-ka mwusep-ta self-self-TOP Mia-NOM be-afraid-of-DECL

'Mia is afraid of herself'

What are the grammatical features of the $(1 \mathrm{~b}-\mathrm{c})$ TOP/NOM-NOM pattern that distinguish it from (1d) with the regular TOP/NOM-ACC pattern?

Certain syntactic similarities between $(1 b-c)$ and $(2 a-b)$ can be regarded as evidence for a "double predication" analysis of $(1 \mathrm{~b}-\mathrm{c})$. First, the order of the 'EXP' and the 'TH' NP-s in (1b-c) (Chelswu and Mia) is fixed: (1b) cannot be translated as 'Mia is afraid of Chelswu'. Similarly, kyongchi 'landscape' cannot be the "major" subject marked TOP in (2a) with the 'As for landscapes, Waikiki's one is good' interpretation. (In general, word order in Korean is free, and a both subject and object can be marked as TOP.) Second, the 'TH' NP in (1b-c) cannot be relativized, as in (5a), similar to the "second subject" in a "double predication" sentence - cf. (5b). Lee and Kim 1988 and Mirto 1998 view this restriction as evidence for the "predicative NP" status of the "second subject" (similar to director in John is a director).

(5)a. Namphyen-i mwusew-un pwuin un husband-NOM be-afraid-of-PART wife-TOP 'A wife that is afraid of her husband is a bad wife',

*'A wife that her husband is afraid of is a bad wife'

b. *Mikwuk-i manh-un kes-un catongcha-0-ta America-NOM a-lot-PART thing-TOP car-be-DECL 'Things that are numerous in America are cars.

The information structure of $(1 \mathrm{~b}-\mathrm{c})$, however, is kind of "frozen", unlike (2a-c), which allows all regular information structure options. First, the TOP-NOM pattern in (1b) is highly preferred to the NOM-NOM pattern in (1c). Second, $(1 \mathrm{~b}-\mathrm{c})$, unlike $(2 \mathrm{a}-\mathrm{b})$, cannot be embedded with the 'EXP' NOM NP being non-focused (cf. (2c) and (6)). Third, neither the 'EXP' NP, nor the 'TH' NP can be a wh-question focus $(7 \mathrm{a}-\mathrm{b})$, whereas both of the two "subject" NP-s in "double predication" sentences can $(8 \mathrm{a}-\mathrm{b})$.

(6) Na-nun Chelswu-ka Mia-ka mwusep-ta-kosayng I-TOP Chelswu-NOM Mia-NOM be-afraid-of-DECL-QUOT

kakha-n-ta

'I think that it is Chelswu who is afraid of Mia';

*'I think that Chelswu is afraid of Mia' think-ASP-DECL 
(7)a. *Nwu-ka Mia-ka mwusep-ni?

somebody-NOM Mia-NOM be-afraid-of-QUEST

'Who is afraid of Mia?'

b. *Chelswu-nun nwu-ka mwusep-ni?

Chelswu-TOP sombody-NOMbe-afrai-of-QUEST

'Who is Chelswu afraid of?'

(8)a. Enu kos-i kyongchi-ka cohni?

some place-NOM landscape-NOM good-QUEST

'What place has a good landscape?'

b. ??Waikhikhi-nun mwues-i coh-ni?

Waikiki-TOP something-NOM good-QUEST

'What is good in Waikiki?',

'What good things does Waikiki have?'

The information structure restrictions mentioned above suggest that the 'EXP' NP in (1b-c) is not only the grammatical subject but also a grammaticalized logical subject, whose sentential predicate is the $[\mathrm{NP}(\mathrm{NOM})-\mathrm{V}]$ constituent. Unlike "double predication" sentences, the 'EXP' NP in (1b-c) is not a "major" subject (that is, not a subject of an additional semantic predication).

The logical subject status of the 'EXP' NP can account for the marginal status of (1c) and the "'EXP' as focus" interpretation of (6), as well as for (7). Since the 'EXP' NP is a grammaticalized logical subject, it cannot be a neutral embedded subject in (6) or be questioned in (7a). The 'TH' NP cannot form a separate information structure entity (e.g. question focus in (7b)) because it is part of the $[\mathrm{NP}(\mathrm{NOM})-\mathrm{V}]$ constituent, which is a grammaticalized predicate for the 'EXP' NP logical subject.

The restriction on the 'EXP' NP - 'TH' NP order mentioned above and the ban on the 'TH' NP relativization in (5a) can also be explained by the "grammaticalized logical subject" hypothesis. 'EXP' must precede 'TH' because logical subject cross-linguistically precedes the sentential constituent predicated over it (Aissen 1999). The 'TH' NP cannot be relativized because a relativized NP must be able to form a separate information structure entity (for instance, because it is realized as a null NP in the relative clause).

To conclude, the 'EXP' and the 'TH' NP-s in TOP/NOM-NOM sentences are arguments of the stative verb, corresponding to grammatical subject and object. In the information structure, the 'EXP' NP is grammaticalized as logical subject, whereas the 'TH' NP is part of the sentential [NP(NOM)V] constituent, predicated over the 'EXP' NP. Such "frozen" information structure results in restrictions on information status options available for both argument NP-s.

Another instance of a clause with two argument NOM NP-s (Agent and Patient), in which the Agent NP has the logical subject status, is the Caucasian "binominative construction" (Kazenin and Testelets 1999, and Kibrik 2003: 353).

\section{REFERENCES}

AISSEN, J. 1999. External possessor and logical subject in Tz'utujil. In: D. L. Payne and I. Barshi (eds.), External possession, 167-193. Amsterdam/Philadelphia: John Benjamins.

HEYCOCK, C. 1993. Syntactic predication in Japanese. Journal of East Asian Linguistics 2, 167-211.

HEYCOCK, C. and Y.-S. LEE. 1989. Subjects and predication in Korean and Japanese. In H. Hoji (ed.), Japanese/Korean Liguistics 1, 239-253. Stanford: SLA Publications.

KAZENIN, K. I. and YA. G. TESTELETS. 1999. Porjadok slov i struktura sostavljajuschix [Word order and constituent structure]. In: A. E. Kibrik (ed.), Elementy tsaxurskogo yazyka $v$ tipologicheskom osveschenii [Studies in Tsakhur: a typological perspective], 293-346. Moskva: Nasledie.

KIBRIK, A. E. 2003. K probleme yadernyx aktantov i ix "nekanonicheskogo kodirovanija": svidetel'stva archinskogo yazyka [On the problem of terms and their "non-canonical coding": evidence from Archi]. In Konstanty i peremennye yazyka [Constants and variables of language], 332-368. S.-Petersburg: Aleteya,

KURODA, S.-Y. 1972. The categorical and the thetic judgment. Evidence from Japanese syntax. 
Foundations of Language 9: 2, 153-185.

LEE, H.-B. and M.-K. KIM. 1988. Double-Nominative constructions in Korean. In Linguistic Society of Korea (ed.), Linguistics in the Morning Calm 2, 489-505. Seoul: Hanshin Publishing Co.

MIRTO, I. M. 1998. The syntax of the meronymic constructions. Pisa, ETS.

TENG, S. 1974. Double Nominatives in Chinese. Language 50, 455-473.

Yoon, J.-H. 2003. Non-nominative (Major) Subjects and Case-stacking in Korean. To appear in: P. Bhaskararao, and K. V. Subbarao (eds.), Non-nominative subjects. Berlin: Mouton de Gruyter. 


\title{
THE SYNTACTIC SUBJECT IN ERZYA WITH POSSESSIVE MARKING
}

\author{
JACK RUETER \\ Mordovian State University, Saransk, Mordovia, Russia
}

In the Erzya language there are suffixes which correlate with the personal pronouns provided that the latter are in the nominative or the genitive. The correlation is so extensive that personal suffixes correlating to the nominative personal pronouns are readily attached to predicative NPs, as well as the finite verb in predicative sentence types. Likewise, possessive suffixes correlating to genitive-form personal pronouns are added to the head of the possession NP in certain cases.

NPs in the Erzya language with genitive-form attributes can be marked with possessive suffixes or determinate/definite markers, which are in apposition to zero-marking indeterminate/indefinite. All three forms of the NP can be observed as the syntactic subject - the indeterminate form, with no marking, and the determinate and possessive forms indicated by suffixes. What makes the possessive suffix interesting is that possessive relations in Erzya are generally anaphoric, whereas the referent of a third person POSSESSOR might be located in the previous sentence or even more remotely; a possessive suffix is an adequate marker for the person of the possessor. Determinate marking, on the other hand, usually indicates contrast or topicalization and tends to require the presence of the possessor.

Possessive suffixes in Erzya indicate virtually the same thing as the genitive forms of the correlating personal pronouns. In the case of third person possession both the pronouns and the possessive suffixes can make direct reference to a genitive-form NP, a feature contrary to that of the Finnish system where the PX appears to be subordinated to the third person genitive-form pronoun. Furthermore possessive suffixes in the Erzya language are used in both possessive and habitive expressions, whereas a habitive construction would be a predication of the possessive relation.

A possessive suffix on the subject of a sentence tends to be used without an accompanying genitive-form pronoun when the possessor is obvious from the THEME of the/a preceding sentence. Hence a lone PX tends to indicate a positionally more remote or by discourse more familiar referent than a personal-pronoun. A construction with the latter, on the other hand, usually entails contrast or topicalization of the focus or more prominent elements of the preceding sentence.

In the Erzya language body-parts such as 'eyes', 'nose', 'ears', etc. are common to the subject of sentences indicating perception. One might immediately regard these as referring to the INSTRUMENT of the verb of perception. The additional usage of possessive suffixes might therefore be seen as an indication of an EXPERIENCER notion in the primary argument of a verb of perception regardless to whether that primary argument involves an ACTOR or an INSTRUMENT, see (1) and (2) below. ${ }^{1}$

(2) Не +и?

$$
\begin{array}{ll}
\text { Сельме +нзэ } & \text { неи+ть } ? \\
\text { еyе/eyes + POSS-PX3SG } & \text { see + PRED-PX3PL } ?
\end{array}
$$

'Do his/her/its eyes see?' > 'Can he/she/it see?'

to-see + PRED-PX3SG?

'Does he/she/it see?'

Constructions with the role INSTRUMENT attributed to the primary argument of the type observed in (1) above, can be attributed a MODAL nuance. Such is the case of other verbs of perception, as well, regardless to whether the verb operates as an intransitive with a single argument or a transitive with two. Nevertheless, it is difficult to find a correlation between the expression of INSTRUMENT and the aforementioned MODAL nuance.

\footnotetext{
${ }^{1}$ ABBREVIATIONS: GEN_DET_SG = Genitive Singular Determinate, GEN-INDET = Genitive Indeterminate (singular or plural), INE+POSS-PX3SG = Inessive (singular or plural) Possessive Suffix Third Person Singular, POSSPX3SG = Possessive Suffix Third Person Singular, PRED-PX3PL = Verbal Conjugation Third Person Plural Subject, PRED-PX3PL_OBJ3 = Verbal Conjugation Third Person Plural Subject, and Third Person Object.
} 
To better assess the usage of this MODAL nuance it is important that we return to the meaning of the Erzya genitive, and the semantics of a statement involving a perception verb with the INSTRUMENT as subject. Firstly body-parts are indicative of a meronymic relation part-to-whole, and secondly perception verbs can take primary arguments with the notion of ACTOR or INSTRUMENT.

From a meronymic viewpoint of example (3) only the INSTRUMENT as a part of the whole is involved. Hence there is no presupposition of a reaction made by the possessor. It is as though the eyes see but no other part of the person becomes involved.

$$
\begin{array}{lll}
\text { Сельме +нзэ } & \text { не +изь } & \text { киска +нть. } \\
\text { eye/eyes+ POSS-PX3SG } & \text { see + PRED-PX3PL_OBJ3 } & \text { dog + GEN_DET_SG? } \\
\text { 'His/her/its eyes saw the dog?' } &
\end{array}
$$

In order to insure the presupposition of involvement of the possessor, the primary argument of the verb of perception 'to see' must be attributed the notion of ACTOR, see (4). Here the verbal marking alone is sufficient.

$$
\begin{aligned}
& \text { eye/eyes+INE+POSS-PX3SG see+ PRED-PX3SG_OBJ3SG dog+ GEN_DET_SG? } \\
& \text { 'He/she/it saw the dog with his/her/its eyes?' }
\end{aligned}
$$

киска + нть.

It will interesting to see whether other instances with the alternation of notions of ACTOR (possessor) versus INSTRUMENT (body-part) attributed to the primary argument also involve a modal nuance. 


\title{
THE SO-CALLED 'BACKWARD CONTROL' AND CLAUSAL COMPLEMENTS OF 'BEGIN' TYPE VERBS IN ADYGHE'
}

\author{
SERGEY SAY \\ Russian Academy of Science (PAH), \\ Institute for linguistics research (ILI), Saint Peterburg
}

Adyghe is a morphologically ergative, predominantly head-final (SOV), pro-drop language with extremely rich system of verb agreement. Basically, the verb agrees with all its arguments. There are distinct sets of agreement markers for A (root adjacent position), and for $\mathrm{O}$ and $\mathrm{S}$ treated uniformly (either leftmost or post-root position within the word form). Since the system of verb agreement normally matches case assignment, these agreement markers are conventionally glossed below as e.g. 1sg.erg, 1sg.abs, 1sg.obl etc. as in the following examples (for the sake of simplicity examples are given in traditional Cyrillic-based Adyghe orthography):

(1) сэ ахэ-р с-щ-агъ-эх

$\mathrm{I}(\mathrm{abs})$ they-abs 1sg.erg-lead-past-3pl.abs

'I led them'

(2) ахэ-р кІу-агъ-эх

they-abs go-past-3pl.abs

'they went'

Importantly, non-finite verb forms (converbs, the so-called supines, etc.) in various complement clauses take exactly the same agreement markers as they would in an independent clause.

The paper focuses on the case-assignment patterns in the Adyghe constructions with 'begin' type verbs that take clausal complements. There are 5 more or less synonymous verbs 'begin' that are discussed below. They fall into three types based on their argument structures, namely, there are two transitive verbs that take ergative nominals as their subjects (егъээсэн and ублэн, cf. 3), one two-argument intransitive verb (фежьээн) that takes an absolutive subject and oblique ergative complement (cf. 4) and two one-argument verbs that take event as their sole argument.

(3) ащ урок-хэ-р ри-гъэжь-агъ-эх

he.erg lesson-pl-abs 3sg.erg-begin-past-3pl.abs

'he starts doing his homework'

(4)

$$
\begin{array}{ll}
\text { сэ урок-хэ-м } & \text { с-а-фежьа-гъ } \\
\text { I(abs) lesson-pl-erg(=obl) } & \text { 1sg.abs-3pl.obl-begin-past } \\
\text { 'I start doing my homework' }
\end{array}
$$

All the five verbs at issue can take either transitive or intransitive verbs as their complements and (somewhat unexpectedly cross-linguistically) convey the meaning of either purposeful or spontaneous initiating of the embedded event.

Before proceeding to the problems of case assignment on subjects of analytical inchoative constructions, it would be germane to mention an option that is available in those cases when the embedded verb is a verb of perception, emotion, etc., namely the possibility of impersonal constructions, such as:

$$
\begin{aligned}
& \text { [сэ орэд-хэ-р } \quad \text { зэхэ-с-хэ-н-х-эу] } \\
& \text { I(erg) song-pl-abs prev-1sg.erg-hear-fut-3pl.abs-conv 3sg.erg-begin } \\
& \text { 'I begin to hear the songs' }
\end{aligned}
$$

Here the phase verb does not agree with any argument corresponding to the participant of the event, although an alternative construction with 1sg.erg agreement on the matrix verb is also possible

\footnotetext{
1 The study reported here was partially supported by the grant of the President of the Russian Federation for the support of leading scientific schools HШ-2325.2003.6
} 
(there is a slight difference in meaning, with (5) not implying conscious intention on the hearer's part; this semantic discrepancy recalls the contrast that is often posited for raising vs. control structures). There is further evidence that proves correctness of the syntactic structure shown by bracketing in (5). In other words, the subject of (5) is overtly represented as an argument of the embedded verb in non-finite form. This option of Adyghe grammar must be kept in mind when discussing personal phase constructions constructions; in these, there is a so-called like-subject constraint (that is, nothing like English "Mother started the maid cleaning the bathroom at ten o'clock" is possible). In other words, the subject of the phase verb (an argument with which the phase verb agrees) must be coreferential with the S-argument of the embedded verb in case the latter in intransitive and with the A-argument of the embedded verb if the latter is transitive. We now will examine case assignment in constructions with intransitive (I) and transitive (II) matrix verbs.

I. Intransitive phase verbs. If both the matrix verb and the embedded verbs are intransitive there appears to be no problem in case assignment on the subject, and it is marked for the absolutive case. However, if the embedded verb is transitive the subject of the construction receives ergative marking:

(6)

$$
\begin{aligned}
& \text { ахэ-мэ сэ с-а-щэ-н-эу фежьа-гьэ-х } \\
& \text { they-erg I(abs) 1sg.abs-3pl.erg-lead-fut2-conv begin-past-3pl.abs } \\
& \text { 'They began to lead me' }=7,8
\end{aligned}
$$

Thus, the argument that is marked for the ergative case triggers agreement of the intransitive phase verb, and the agreement marker belongs to the set of absolutive agreement markers - an otherwise unattested option in Adyghe. In such constructions the subject can receive absolutive marking only under an unusual word order pattern (which may be due to pragmatic factors), e.g.:

$$
\begin{array}{llll}
\text { aхэ-р } & \text { фежьа-гъэ-х } & \text { сэ } & \text { с-а-щэ-н-эу } \\
\text { they-abs } & \text { begin-past-3pl.abs } & \text { I(abs) } & 1 \text { sg.abs-3pl.erg-lead-fut2-conv }
\end{array}
$$

The contrast between (6) and (7) together with some further evidence, and in view of the aforementioned ability of subjects to remain overtly expressed within the embedded clause, allows one to conclude that the ergative pronoun in (6) is the subject of the embedded clause. Similar patterns have been reported for some dozen of languages (though never, to my knowledge, for Adyghe); such a configuration is usually referred to as 'backward control' (see Polinsky and Potsdam 2002 and references therein), since a fuller structure reconstructed for (6) would be something like (8), which is strongly reminiscent of the usual (forward) control pattern except for the fact that it is the structurally superior 'copy' that remains mute, unpronounced, deleted or whatever is the terminological convention of a particular formalism:

$$
\begin{aligned}
& 0_{\mathrm{i}} \quad \text { [ахэ-мэ } \\
& \text { they-abs they-erg I(abs) 1sg.abs-3pl.erg-lead-fut2-conv begin-past-3pl.abs }
\end{aligned}
$$

There are, however, further facts that pose problems for the 'backward control' type of analysis. First, even one-argument 'begin' verbs can appear in structures totally parallel to those in (6). However, the control analysis for those verbs seems to be unmotivated, since control structure presupposes an external argument of the matrix verb, which is not the case of the Adyghe one-argument verbs ежьэн 'start' and хъун 'begin, become'. Second, there seem to be no constraints on the use of the pattern represented in (6) that are usual for the control verbs, such as animacy (volitionality, agentivity etc.) of the subject.

II. Transitive phase verbs. If both the matrix and the embedded verbs are transitive the subject is as expected marked for ergative. However, if the embedded verb is intransitive, then a mirror image of the structure in (6) is possible for the (transitive) verbs егъэжьэн and ублэн 'begin' (9) along with more expected (10):

$$
\begin{aligned}
& \text { [ахэ-р къэшъо-н-х-эу] } \\
& \text { they-abs dance-fut-3pl.abs } \\
& \text { 'they began to dance' }=10
\end{aligned}
$$

р-а-гъэжьа-гъ

3sg.abs-3pl.erg-begin-past 
(10) ахэ-м [къэшъо-н-х-эу] they-erg dance-fut-3pl.abs 3sg.abs-3pl.erg-begin-past

The basic 'strangeness' of (9) is that the absolutive argument that receives its case from the embedded verb triggers agreement on the matrix verb. Once again, word order phenomena together with some further indications allow us to assume that the overt subject belongs to the embedded clause in (9) and to the matrix clause in (10), as suggested by bracketing. The preference for ergative vs. absolutive marking of subjects in 'begin (tr.) + V (intr.)' constructions seems to be dependent on a number of factors: i) the matrix verb: out of the two transitive 'begin' verbs there is one (ублэн) that strongly favors ergative marking; ii) the semantic type of embedded event and agentivity of subject; iii) the morphological type of complement. Once again, the data seem to resist the usual formalist approach, in which the contrast between structures in (9) and (10) would be treated as merely a contrast between 'forward' and 'backward' control. Out of the three properties in (i)-(iii), this contrast cannot capture only the first one.

\section{CONCLUSIONS AND SUGGESTIONS.}

1) In the spirit of Kibrik (2003: 472) who discusses a Lak pattern very similar to that in (6), I would prefer to leave the problem of formal characterization of the discussed phenomena unanswered, noticing in passing that they may posit some inconvenience for the usual formal syntactic models. In order to avoid unnecessary theoretical implications it seems to be more theoretically neutral to label the structures in e.g. (6) or (9) 'backward concord' rather than 'backward control' (cf. Kozinsky et al. 1988: 701, fn. 11).

2) Case assignment in Adyghe verb complexes appears to be dependent on a whole range of various factors, syntactic as well as lexical and semantic. On closer examination, the latter group of factors seems to show some relevant hierarchies compatible with the Transitivity hypothesis (Hopper \& Thompson 1980) with ergative subject marking gravitating towards the Transitive pole of the corresponding continua.

3) The paper adds to the growing database of already documented 'backward subject control' configurations. There seems to be some interest in the areal-typological assessment of this typologically unusual phenomenon, since it has been reported for several Caucasian (Daghestanian) languages, such as e.g. Tsez, Bezhta, Tsaxur, Lak. Besides, the lists of verbs allowing backward concord in various languages appear to be strikingly and not quite yet understandably homogenous, with 'begin' verbs as probably the likeliest entry in such a list.

\section{REFERENCES}

HopPer, P.J. and S. A. ThOMPSON. 1980. Transitivity in grammar and discourse. Language 56: 2 , 251-350.

KIBRIK, A.E. 2003. Konstanty i peremennye jazyka. Sankt-Peterburg: Aleteja. POLINSKY, MARIA, and ERIC POTSDAM. 2002. Backward control. Linguistic Inquiry 33, $245-282$. 


\title{
FUNCTIONS OF JAPANESE ZERO-PREDICATE FINAL PARTICLES
}

\author{
YUKA SHIGEMITSU \\ Tokyo Polytechnic University, Kanagawa, Japan
}

The purpose of this study is to introduce the usages of zero-predicate final particles. Isolated final particles are often used in oral communication in Japanese, although Japanese final particles are usually located after predicates.

Final particles convey how a speaker transmits his or her message to the target hearer. For example, $-k a$ as in Ikimasu-ka ('Are you going') is used when the speaker does not have the information and believes the target hearer has the information. So the example should be interpreted as 'I (the speaker) do not know whether you (the target hearer) will go or not. Therefore, I am asking it to you.' '-ne' as in Oishi-ne ('It is delicious') is used when the speaker believes both the speaker and the target listener have and share the same information. So the example should be interpreted as 'I (the speaker) know you (the target hearer) feel the food is delicious and I have the same idea. Therefore, I am confirming.' '-yo' as in Gohan desu yo ('The dinner is ready') is used when only the speaker has the information and the speaker knows that the target hearer does not have the information. So the example should be interpreted as 'I (the speaker) know you (the target hearer) do not know that the dinner is ready. Therefore I am informing it to you.'

Although these final particles are usually located after the predicate, we find isolated final particles that do not have a preceding predicate. For example, ' $N e$ ' conveys 'do you agree with me?' or 'but' according to the context. 'Ne, ne, $n e$ ' is used when the speaker forced the target hearer to agree with the speaker's idea.

This presentation illustrates such isolated usages of zero-predicate final particles, then discusses the usages from the morphological and pragmatic points of view. 


\title{
DERIVATIONAL ACTIVITY OF FOREIGN ELEMENTS IN KARACHAY-BALKAR
}

\author{
EWA SIEMIENIEC-GOŁAŚ \\ Jagiellonian University, Institute of Oriental Philology, Kraków, Poland
}

Karachay-Balkar is one of the Turkic languages upon which many other languages had active influence.

The homeland of the Karachay-Balkar speakers is the Northern Caucasus. During the course of history the ancestors of contemporary Karachays and Balkars had contacts with various peoples and their languages, such as: Arabic, Iranian languages (including Persian and Ossetian), Turkic languages (including Turkish), Kabardian, and Russian.

Since the XIXth century, when the Caucasus was incorporated into Russia, a large number of Russian loan words entered the Karachay-Balkar language. The activity of Russian lexical elements in Karachay-Balkar is noticeable and manifested in various aspects. Together with Russian loan words so called "international" words also entered Karachay-Balkar and their number inevitably grows.

The purpose of this paper is to present how Russian and "international" elements are active on the ground of Karachay-Balkar word formation.

Given the agglutinative character of the Karachay-Balkar language, only suffixes are involved in the process of its word formation. In our analysis we take into consideration only suffixes of native origin, i.e. Turkic.

To have a possibility of estimating the scale of formative activity of the above mentioned elements we took into consideration both nominal and verbal derivatives. The analysis of the lexical material collected from the modern sources shows that on the basis of nominal word formation the following suffixes are very active: $-(a \backslash i) u$, $-\check{c} i$, $-l i$, - lik, - siz. Examples:

Suffix $-(\mathbf{a} \backslash \mathbf{i}) \mathbf{u}$ :

avtomatlau 'automatization' < avtomatlanirga 'to automatize';

demonstracijalau 'demonstration' < demonstracijalarga 'to demonstrate';

Suffix -či :

astronomijači 'astronomer' < astronomija 'astronomy';

avantürači '1.wrangler. 2.adventurer' < avantüra '1. wrangle. 2. adventure';

fabrikači 'factory owner' < fabrika ' factory ';

revolucijači 'revolutionist ' < revolucija 'revolution';

Suffix -li :

absolutlu 'absolute' < absolut 'the absolute';

diskussijali 'controversial' < diskussija 'discussion';

kalibrli 'having a certain calibre' < kalibr 'calibre';

Suffix - lik :

banditlik 'banditism' < bandit 'bandit';

bankrotluk 'bankruptcy' < bankrot 'bankrupt';

direktorluk 'the function of a director' < direktor 'director';

redaktorluk 'editorship, editoring' < redaktor 'editor';

Suffix -siz :

kalorijasïz 'caloryless' < kalorija 'calory';

kvalifikacijasiz 'without qualification' < kvalifikacija 'qualification';

magnitsiz 'demagnetized' < magnit 'magnet'.

Not only nominal suffixes take part in the process of derivation from Russian and "international" bases but also verbal and infinitive forming suffixes. The process is observed on a wide scale. 
The suffixes -la, -lan, added to the nominal elements, form the verbal bases. There are quite frequent examples that these suffixes are also added to Russian and "international" bases, e.g.:

demokracijalan- 'to democratize' < demokracija 'democracy' +suf. -lan; duxla- 'to scent somebody' $<d u x$ 'perfume' + suf. -la.

The infinitive forms are made with suffixes: -arga, -erge; -irga, -ïrga -urga, -ürge.

Not only native elements but also "international" and Russian words are involved in the process forming infinitive, e.g.:

demokracjalanirga 'to democratize' < demokracijalan- +suf. -ïrga; mašinalarga 'to mechanize' < mašinala- + suf. -rga.

From such bases are also formed some forms expressing the categories of mood and voice.

The analysis presented leads to some conclusions.

First of all, it is noticeable that Russian and "international" words (mostly nominal forms) constitute very active formative bases in the process of derivation in Karachay-Balkar.

In this process new, both nominal and verbal forms are formed. Paralel to these conclusions we have to pay attention to the great productivity of several formative suffixes such as: $-(a \mid i) u,-c \check{c} i,-l a$, $-l a(n),-l i,-l i k,-s i z$.

Most of those suffixes are also known in other Turkic languages where some of them are very productive as well. 


\title{
RECONSIDERING GRAMMATICAL RELATIONS IN FUNCTIONAL GRAMMAR
}

\author{
ANNA SIEWIERSKA, University of Lancaster \\ DIK BAKKER, University of Amsterdam
}

Functional Grammar (FG; Dik 1997) has a very restricted view of on GRs. Employing the traditional notions Subject and Object, FG recognises grammatical relations only in case they generalize over both arguments of a bivalent predicate. For its functional motivation, Subject is assumed to be the grammatical implementation of the extra-grammatical notion of perspective on the state of affairs which is represented in a sentence. Perspective is exclusively expressed by a combined set of morphosyntactic coding and behavioural properties typically associated with subjects in the linguistic literature, such as zero case marking, verb agreement, constituent order, conjunction reduction, raising etcetera. Objects provide a secondary perspective, and are associated mainly with dative shift. Under this strict definition, only very few languages turn out to have Subjects, and even fewer have Objects. Also, FG does not allow for multiple subjects, as in Role \& Reference Grammar (Van Valin $\&$ LaPolla 1997) and other theories. In our paper, we would like to reconsider this position in FG, making GRs applicable to a wider set of languages. At the same time, this will provide us with a broadly applicable typology and a diachronic scenario relating the respective language types historically. Taking a sample of languages of Europe and North and Central Asia for our empirical basis, we will discuss a definition of GRs in terms of the linkage of the core arguments to the Dynamic Expression Rules of FG as introduced in Bakker (2001). Rather than implement a type of competence model of a grammar, these rules seek to model what speakers actually do when uttering a sentence. We will look at a restricted set of morphosyntactic phenomena as proposed in Givon (1997) as the explanandum and a language specific subset of functional features as the explanans of our exercise.

\section{REFERENCES}

BAKKER, D. 2001. The FG expression rules: a dynamic model. Revista Canaria de Estudios Ingleses $42,15-54$.

DIK, S.C. (1997). The Theory of Functional Grammar, part I. Berlin: Mouton de Gruyter.

GIVÓN, T. (1997). Grammatical Relations: An Introduction. In T. Givón (ed.) Grammatical Relations, 1-84. Amsterdam: John Benjamons,

VAN VALin, R.D. and R. LAPOLla (1997). Syntax: Structure, Meaning and Function. Cambridge: Cambridge University Press. 


\title{
PREDICATE PLURALITY AND PREDICATE-ARGUMENT STRUCTURE: ON THEIR INTERACTION
}

\author{
ANDREY SHLUINSKY \\ Moscow State University, Philological faculty
}

In contemporary aspectology the distinction between "phase" and "quantitive" aspect is generally accepted (cp., for example, Plungian 1997). As regards quantitive aspectual meanings, the distinction between "iterative" (in the broad sense, i. e. including "multiplicative" type) and "distributive" types of predicate (or "verbal") plurality (cp. Dressler 1968: 62-74; Khrakovskij 1989: 22-50; Dolinina 1996: 232-245) is also generally accepted. In the first case a situation with the same set of participants is repeated several times (as in Russian: $U$ etoj ženš iny izbivali syna 'This woman's son was beaten'). In the second case every time another participant (or another participants) take part in the situation, and that is the reason why the situation is repeated several times (as in Russian: U mnogix ženš' in po-izbivali synovej 'Many women's sons were beaten', where the prefix po- is the marker of the distributivity). In other words, "iterative" meanings in the domain of predicate plurality don't presuppose any changes in the predicate-argumnet structure of the sentence (the predicate maintains the initial set of the arguments and their marking in the syntactic structure), and "distributive" meanings entail changes in the predicate-argument structure (the predicate changes its set of the arguments, and this change is often attended with changes in the syntactic structure (cp. Russian: Mal'čik dal d'evočke jabloko 'The boy gave the girl an apple', and Mal'čik dal d'evočkam po jabloku 'The boy gave each girl an apple', where the preposition phrase po jabloku '(lit.) at an apple' is used instead of direct object noun phrase jabloko 'apple').

The opposition of "iterative" and "distributive" types should mean that if a language has a special marker of predicate plurality meanings, then it can be either a special marker of "iterative" plurality, or a special marker of "distributive" plurality, or there are two different special markers for the both types.

However, in Tundra Nenets (Malozelemlsky dialect) ${ }^{1}$ both types of the predicate plurality are combined in the same marker of so-called Frequentative (in terms of [Salminen 1997]) -or-.

When the Frequentative marker is added to an intransitive verbal stem, the "iterative" type of predicate plurality is always the result: ${ }^{2}$

$$
\begin{aligned}
& \text { (1) a. wan'axarda-xonanda xaji. } \\
& \text { Van'ahouse-1SG.LOC.SG stay.3SGs } \\
& \text { 'Van'a stayed home.' } \\
& \text { b. wan'axusuwej jal'a xarda-xonanda xaj-ur-na. } \\
& \text { Van'a every day house-1SG.LOC.SG stay-FREQ-3SGs } \\
& \text { 'Van'a stays home every day.' }
\end{aligned}
$$

When the Frequentative marker is added to transitive verbal stems the result can be both the "iterative" (as in (2)) and the "distributive" (as in (3)) types:

$$
\begin{aligned}
& \text { (2)a. wan'ap'et'am? p'is'ila-pta. } \\
& \text { Van'a P'et'a-ACC.SG laugh-TRANS.3SGs } \\
& \text { 'Van'a made P'et'a laugh.' } \\
& \text { b. wan'ap'et'am? xusuwej jal'a p'is'ila-pt-or-na. } \\
& \text { Van'a P'et'a-ACC.SGevery. day laugh-TRANS-FREQ-3SGs } \\
& \text { 'Van'a makes P'et'a laugh every day.' }
\end{aligned}
$$

\footnotetext{
${ }^{1}$ Tundra Nenets material was collected during the field research of the Nenets Linguistic Research of the Philological faculty, MSU, 2003, with support of RFH, grant №03-04-18005e.

${ }^{2}$ AbBreviations. 1, 3 - 1, 3 person, FREQ - Frequentative, LOC - Locative, s - "subject", conjunction type, $\mathrm{SG}$ - singular, PL - plural, RANS - Transitive.
} 


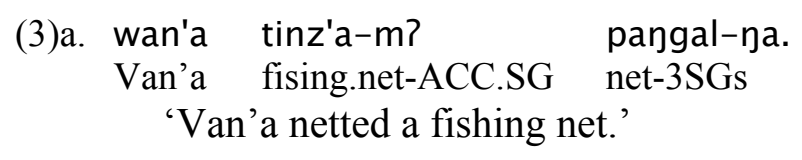

b. wan'axusuwej jal'a tinz'a-?mna pangal-or-na.

Van'a every day fishing.net-PROS.PL net-FREQ-3SGs

'Van'a nets a fishing net every day.'
c. "wan'a tinz'a-m? pangal-or-na.
Van'a fishing.net-ACC.SG net-FREQ-3SGs

In (2b) the second argument of the predicate is the same when the situation repeats; there are no semantic or syntactic changes while buliding Frequentative. In (3b) the second argument of the predicate is another object when the situation repeats the next time; this argument syntactically is not an Accusative (as in (3a)), but Prosecutive (in [Tereschenko 1956] there is some information on this frame). Particularly crucial is the fact that the Frequentative of this group can never be used with an Accustive argument (3c).

In the paper will be examined some constraints on building a Frequentative with the properties like (2b) and like (3b).

\section{REFERENCES}

DOLININA, INGA B. 1996. Kolichestvennost' v sfere predikatov (kategorija "glagol'noj mnozhestvennosti"). [Quantity in the domain of predicates]. In Bondarko, Aleksandr V. (ed.). Teorija funkcional'noj grammatiki. Kachestvennost'. Kolichestvennost'. [Theory of the functional grammar. Quality. Quantity]. St. Petersburg,

Plungian, VLADIMIR A. Vid i tipologija glagol'nykh sistem. 1997. Aspect and verbal systems' typology. In Chertkova, Marina Ju. (ed.) Trudy aspektologicheskogo seminara filologicheskogo fakul'teta MGU im. M.V. Lomonosova. [Papers of the aspectology seminar at the philological faculty, M.V.Lomonosov Moscow State University]. Vol. 1. Moscow,

TERESCHENKO, NATAL'JA M. 1956. Materialy i issledovanija po jazyku nencev. [Materials and research on the Nenets]. Moscow - Leningrad.

KHRAKOVSKIJ, VIKTOR S. 1989. Semanticheskije tipy mnozhestva situacij i ikh jestestvennaja klassifikacija. [Semantic types of the situations' plurality and their natural classification]. In Khrakovskij, Viktor S. (ed.) Tipologija iterativnykh konstrukcij. [Typology of iterative constructions]. Leningrad.

DRESSLER, WOLFGANG. 1968. Studien zur verbalen Pluralität. Wien.

SALMINEN, TAPANI. 1997. Tundra Nenets inflection. Helsinki: The Finno-Ugrian Society. 


\title{
ASPECT IN RUSSIAN AND TURKISH: SEMANTICS AND PRAGMATICS OF A GRAMMATICAL CATEGORY
}

\author{
BARBARA SONNENHAUSER \\ University of Leipzig, Department of Slavic Languages
}

The multitude of readings of the Russian aspects - particularly the ipf ${ }^{1}$ (Table 1) - and the comparison with aspectual usage in the respective English and Turkish equivalents raises the question of how to account for those different readings and the cross-linguistic differences. This paper deals in particular with the following questions: is there an invariant meaning to be found in the Russian pf and ipf aspect, or are we dealing with grammatical polysemy? Are there any regularities in deriving the different readings - language-internally as well as cross-linguistically? What is the common denominator that justifies the subsumption of certain phenomena under the heading of 'grammatical aspect'?

This paper will argue for a so-called 'selectional theory' (Bickel 1996; Johanson 1971; 2000) of aspect in combination with well spelled-out pragmatic principles in the sense of Levinson's heuristics (Levinson 2000). This approach has certain advantages: it captures the crucial assumption that lexical content and aspect ('situation aspect' and 'viewpoint aspect', Smith 1997) strictly have to be separated, and it provides a cross-linguistic skeleton that allows for systematic language-specific derivation of aspectual readings and for systematic explanation of the cross-linguistic differences.

Within a selectional theory of aspect (Figure 1) phases and boundaries constitute the decisive units accessible for aspectual selection by special markers like the English progressive -ing, the Turkish markers -iyor $(d u)$ and -miş, and the Russian pf aspect. Assumed is a tripartite event structure, consisting of a preparation phase (dynamic phase $\varphi_{\mathrm{dyn}}$ ), a culmination point (boundary $\tau$ ) and a consequent state (static phase $\varphi_{\text {stat }}$ ). Selection is to be understood as making visible a relevant part of an event and making it accessible to truth-conditional evaluation at a certain interval of time ('točka otsčeta'/TO; Padučeva 1996) that may be located after that relevant part of the event or within that part of the event (retrospective/synchronous; Padučeva 1996), thereby distinguishing different groups of aspectual readings (Table 1). Selecting a certain part of an event does not mean dropping or cutting of the rest of the event, rather selection means 'asserting' and leaving the other parts of that event for presupposition or implicature.

Verbs are classified in terms of combinations of phases and boundaries (Johanson 2000; Bickel 1996), that may be part of the semantic representation of the verb, emerge as the result of VPcomposition, or may be pragmatically induced. So the question of class-affiliation of verbs to one of the Vendlerian classes becomes irrelevant, at least with regard to issues of grammatical aspect. The advantage of such an approach is that 'coercion' or 'recategorization' can be captured by simple composition - semantically or pragmatically achieved. No combinations are excluded a priori, as appears to be the case within Vendlerian approaches that classify verbs according to their internal temporal properties and exclude, e.g., the combination of the progressive with stative verbs. The same holds for the argument structure of the verb that is fixed only during interpretation and not in the lexicon. This assumption avoids the difficulties of Vendlerian approaches with classifying verbs like 'eat' and 'eat something' (cf. Marten 2002 who argues within the framework of dynamic syntax for an underspecified representation of verbal argument strucuture that is to be fixed only during interpretation).

Figure 1 shows only the marked members of the aspectual categories in the respective languages. This does not imply that the unmarked members are semantically vacuous. Rather, they are sense-general (Atlas 1989), i.e. they have a definite meaning, but this meaning is neutral insofar as it is neither identical to one of the readings nor to the sum of them. Accordingly, theses forms are instances of underspecification that receive the appropriate specific reading in the course of interpretation. This serves as an argument against grammatical polysemy and strongly suggests that semantics alone is not enough in deriving aspectual readings, and that some pragmatics is needed, pragmatics being understood as "taking context into account in a principled way" (Bunt 2000: 25).

\footnotetext{
${ }^{1} \mathrm{ipf}=$ imperfective aspect, $\mathrm{pf}=$ perfective aspect.
} 


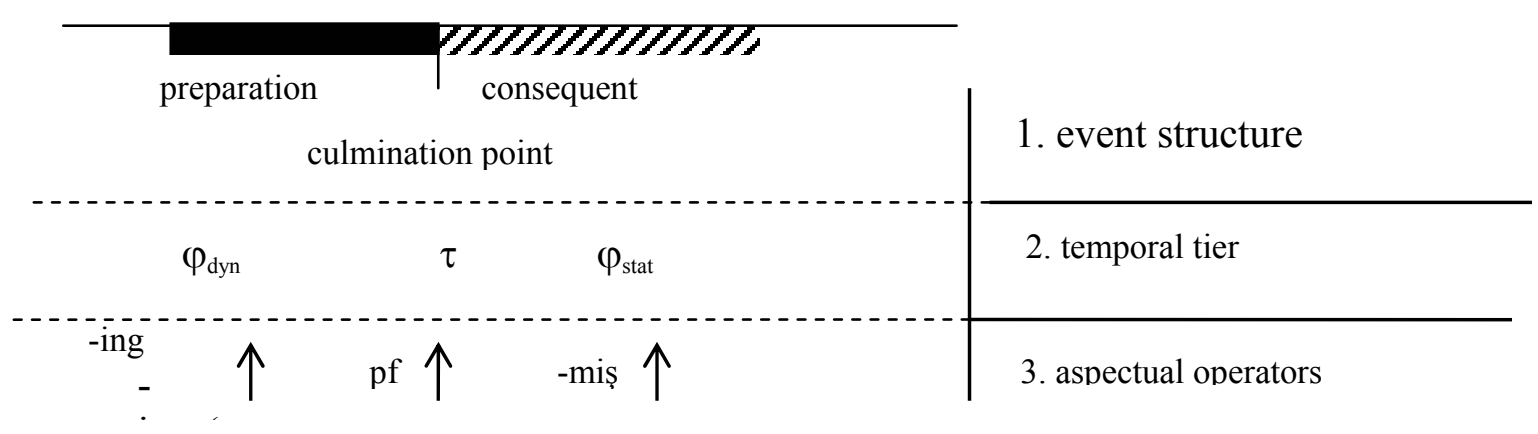

FIGURE 1: A schematic sketch of selection theory.

Here we will concentrate mainly on the pragmatic principles involved in the derivation of aspectual readings. These principles are basically Levinson's three heuristics, which are based on the Gricean Maxims of Conversation and constitute default rules for interpretation that act on different levels of aspectual composition: the I-heuristic elaborates the underspecified semantic representations to yield truth-evaluable propositions, which are taken as input to purely pragmatic inferences governed by the Q- and M-heuristics.

Q-implicatures act on the level of grammatical aspect and are based on the principle of providing the strongest statement possible, thereby inducing scalar implicatures based on hierarchically ordered sets of linguistic alternates. As regards Russian aspect, this scale is $\left\langle\mathrm{pf} ; \varnothing^{2}>\right.$, the pf aspect explicitly selecting a boundary, whereas the ipf aspect does not exclude that selection, thus allowing also for the denotation of completed and bounded events (general-factual and durativer reading). The possibilities for the concrete interpretation of this Q-implicature are constrained by the interaction of the aspectual value of the marker with the aspectual reference interval TO which can be synchronous ('normal' and 'over-long', Padučeva 1996) or retrospective. At TO the viewpoint value of the respective marker is asserted and truth-conditionally evaluated. That aspectual value can be captured by Klein's (1995) temporal-relational analysis of aspect, where aspect is defined as the relation between the situation-time T-Sit and T-Ast, the time for which an assertion is made. According to selection theory, T-Sit has to be further specified in terms of the respective phases and boundaries that are selected.

M-implicatures are based on the principle of indicating anormal, nonstereotypical situations by using marked expressions. 'Marked' here means the application of an aspectual marker on a verbal basis that has to undergo a pragmatic inferential process to be a suitable basis for that marker to apply. This is what traditionally is labelled 'recategorisation' or 'aspectual coercion' and for which usually coercion operators are postulated (Pulman 1997). These implicatures work on the level of aspectual class, i.e. they yield to the induction of phases and boundaries if necessary.

The derivation of Q- and M-implicatures, that is the selection/induction of phases and boundaries and the specification of the temporal relation is not yet enough for specifying the concrete, contextually relevant reading. This is achieved by the derivation of I-implicatures. They differ from the former kinds of implicatures in that they are not based on linguistic alternates and thus are not metalinguistic, but instead invoke world-knowledge of stereotypical relations thereby enriching the lexical content of the aspectual phrase. As these implicatures are necessary for the generation of truth-evaluable propositions, they can not be regarded as implicatures in the sense of the above mentioned. They rather constitute what Relevance-Theory calls explicatures.

The selectional and pragmatic principles of computation can be claimed to be crosslinguistically valid, but their concrete realization depends on language-specific grammatical and lexical features. This is partly exemplified in Table 1, which shows the readings of the Russian ipf aspect and how TO helps in disambiguating: Whereas in Turkish TO is morpho-logically encoded in the aspectual marker, it has to be fixed contextually in Russian. The concrete readings then have to be further specified within the groups I-III (Padučeva 1996) by means of I-implicatures:

${ }^{2} \varnothing$ means 'semantically unmarked' 


\begin{tabular}{|c|c|c|c|c|}
\hline & Russian & Turkish & TO & Relation \\
\hline I. & $\rightarrow$ actual-processual, iterative & -iyor $(\mathrm{du})$ & $\begin{array}{c}\text { synchronous, } \\
\text { normal }\end{array}$ & T-Ast included in $\left[\varphi_{\text {dyn }}\right]$ \\
\hline II. & $\rightarrow$ general-factual, durative, it- \\
erative & $-\mathrm{di}$ & retrospective & T-Ast includes $\left[\varphi_{\text {dyn }} \tau \varphi_{\text {stat }}\right]$ \\
\hline III. & $\begin{array}{c}\rightarrow \text { habitual, continuous, } \\
\text { potential, permanent, atemporal }\end{array}$ & Aorist & $\begin{array}{c}\text { synchronous, } \\
\text { over-long }\end{array}$ & $\begin{array}{c}\text { T-Ast simultaneous with } \\
{\left[\varphi_{\text {dyn }} \tau \varphi_{\text {stat }}\right]}\end{array}$ \\
\hline
\end{tabular}

TABLE 1. Ipf aspect in Russian and Turkish.

This approach allows for a systematic account of aspect, in that it captures the cross-linguistic common denominator, namely selection of phases and boundaries. Language-internal as well as cross-linguistic regularities in deriving aspectual readings are captured by the interaction of the aspectual value with TO and the combination with the pragmatic principles stated. The cross-linguistic differences in aspectual usage are due to language-specific factors that have to be taken into account to systematically flesh out the semantic and pragmatic skeleton presented here. Within this approach, these differences can be systematically predicted and explained.

This paper has concentrated mainly on the ipf aspect in Russian and its equivalents in Turkish. But the theoretical assumptions provided can be applied along this lines to the Russian pf aspect and to the Turkish postterminality marker -miş, and should also be applicable to other languages with grammatical aspect.

\section{REFERENCES}

ATLAS, J. 1989. Philosophy without Ambiguity. Oxford.

BICKEL, B. 1996. Aspect, Mood, and Time in Belhare. Zürich.

BLAKEMORE, D. 2002. Relevance and Linguistic Meaning. Cambridge.

BUNT, H., and B. BLACK. 2000. The ABC of computational pragmatics. In: Bunt, H., and W. Black (eds), Abduction, Belief and Context in Dialogue, 1-46. Amsterdam.

CARSTON, R. 2000. Thoughts and Utterances. Oxford.

GRICE, P. 1989. Studies in the Way of Words. Cambridge.

JACKENDOFF, R. 1997. The status of thematic relations in linguistic theory. Linguistic Inquiry 18: 3, 369-411.

JOHANSON, L. 1971. Aspekt im Türkischen. Uppsala.

JoHANSON, L. 2000. Viewpoint operators in European languages. In: Dahl, Ö. (ed.), Tense and Aspect in the Languages of Europe, 27-179. Berlin, New York.

KLEIN, W. 1995. A time-relational analysis of Russian aspect. Language 71: 4, 669-695.

LEVINSON, S. 2000. Presumptive Meanings. Cambridge, London.

MARTEN, L. 2002. At the Syntax-Semantics Interface. Verbal Underspecification and Concept Formation in Dynamic Syntax. Oxford.

Moens, M., and M. STEEDMAN. 1988. Temporal ontology and temporal reference. Computational Linguistics 14: 2, 15-28.

NAKHIMOVSKY, A. 1988. Aspect aspectual class, and the temporal structure of narrative. Computational Linguistics 14: 2, 29-43.

PADUČEVA, E.V. 1996. Semantičeskije Issledovanija. Moskva.

PUlman, S. 1997. Aspectual shift as type coercion. Transactions of the Philological Society 95: 2, 279-317.

SMITH, C. 1997. The Parameter of Aspect. Dordrecht.

SteEdman, M. 2002. The Productions of Time. Draft. 


\title{
EVENT STRUCTURE, ASPECT, AND QUANTIFICATION: A CASE STUDY ON FINNISH AND UDMURT
}

\author{
PIRKKO SUIHKONEN \\ University of Helsinki, Department of General Linguistics
}

This paper deals with quantification in event structures, and relationships between event structure and quantifying adverbials. The goal is to investigate how quantification expressed with sentential adverbials, or adverbials quantifying over verbal phrases interact with internal quantification of events (situation types), and quantification expressed with morphological means included in the predicates.

Argument structure consists of a predicate and NPs which have the main syntactic and semantic functions in the sentence structure. Structure building operations, e.g., passivization, and causativization which change the syntactic and semantic relationships of functional elements in sentences have their scope in the argument structure. Semantic properties, such as quantification and aspect which can be expressed with different kind of structural means reflect and specify syntactic and semantic relationships in the argument structure. The concept "event structure" is close to the concept "argument structure", but, when argument structure acts at syntactic and semantic levels, in the event structure, also the semantic relationships based on the inherent properties of predicates, and external temporal framework are taken into account. ${ }^{1}$

A basic classification of predicate types can be done on the basis of the number of obligatory arguments the predicate accepts: we speak of one-place, or two-place predicates, etc. All the NPs in the sentence structure are not arguments: e.g., the NPs which are semantically instruments are located outside the argument structure. Descriptions of the argument/event structure vary with respect to the theoretical approach of the analysis. According to the terms presented in Role and Reference Grammar, the predicate is located in the nucleus, and the arguments in the core of the sentence structure. Some adverbs, e.g. those expressing modality or aspect are located in the core. The argument structure is seen as a relationship between the elements located in the nucleus and core (Van Valin \& LaPolla 1997: 154-178). In generative theory, the argument structure is considered to refer to grammatical relationships dependent on the properties of predicates and their relationships with the arguments. Argument structure is a combination of inference between lexical semantic structure and grammatical relationships. "Argument structure is projected from lexical semantic structure, and dstructure is projected from argument structure and principles of X-bar theory" (Grimshaw 1994: 2). In Grimshaw's own description, in addition to the common generative framework, also the aspectual relationships of sentences are taken into account (Grimshaw 1994).

In the classification of aspect, Grimshaw follows the classical study of Zeno Vendler (1967) (in fact, "Aristotele-Ryle-Kenny-Vendler" (cf. Dowty 1979: 51-52)), according to which the predicate types are classified into four basic aspectual groups: states, activities, achievements, and accomplishments (cf. Table 1). This classification which represents aspectual types of situations (Comrie 1976: 13, 48-51) has been a basis of numerous works done in describing the aspectual semantics of predicates (cf., e.g., Tenny \& Pustejovsky 2000). According to the most widely accepted definition of aspect, aspect is defined as a temporal course of an event or a situation (cf. Comrie 1976). Terms such as continuative, frequentative, progressive, perfective, or momentary, are used in this classification (Comrie 1976; cf. also Cinque 1999: 83-106). The systems of how aspect is expressed in the languages vary remarkably. E.g., in Russian, the aspect is expressed with verbal prefixes and suffixes, but in Finnish, case marking of the main syntactic arguments has an important role in marking aspectual relationships: the arguments marked with the nominative or genitive case occur in sentences which express closed situations, and the arguments marked with the partitive case represent unclosed situations or states (Table 1, example 4; Suihkonen 2003). Both aspect types imply information on quantification. Quantifying temporal relationships with regard to the aspect of situation were already described by Zeno Vendler and particularly David Dowty (1979: 71-). Functionally, quantifiers are operators. For characterizing different types of quantification, Barbara $\mathrm{H}$.

${ }^{1}$ There are several terms which are used to characterize situations or event types. On the history of the study of event structures, cf., e.g. Tenny \& Pustejovsky 2000. 
Partee has introduced the term "D-quantification" for quantification expressed with determiners, and "A-quantification" for quantification expressed with affixes, auxiliaries, adverbs, and argumentstructure adjusters. The elements which are classified as belonging to A-quantification are complex, and A-quantification can be divided to sub-types (Partee 1995: 544-556, 577-). In the predicate level, quantification concerns modification of predicate and its relationship to the obligatory argument. The terms used in classifying aspect types typically are terms that characterize different kind of quantification: the terms "iterative", "momentary", or "continuative", represent, in addition to aspect types, also A-type quantification expressed with predicates.

Finnish and Udmurt are synthetic languages in which suffixation has an important role in word formation. The verbal derivational system of Finnish contains suffixes which change the meaning of the predicate to momentary, frequentative, causative, etc. Also the derivational system of Udmurt shows variety comparable with that of Finnish. Derivation system of Udmurt is different from that in Finnish in the way that Udmurt has two conjugational classes, $-y$ - and - $a$-conjugation. Usually, when connected with non-derived verbal roots, the suffix $-a$ - occurs with verbs expressing continuative predicates, and the suffix $-y$ - with verbs which are non-continuative. Stems that already contain a derivational suffix can be a basis of a new derivational process.

Fin $h e i l+u+a$ 'swing (R+REFL-PASS +INF)' $-h e i l+u+t t a+a$ 'sway, wave (R+MID+CAUS+INF)' $h e i l+u+t+e l+l a$ 'sway, swing, keep swinging (R+MID+CAUS+FREQ+INF)' $-h e i l+a h t a+a$ 'sway, swing (once) $(\mathrm{R}+\mathrm{MOM}+\mathrm{INF})$ '.

Udm šon $+t+y+n y$ 'to wave, lift (one's hand) (R+CAUS+SEMF+INF)' - šon $+a+n y$ 'to wave; shake (one's head) (R+CONT+INF)'- šon $+a+l ' l$ ' $+a+n y$ 'to wave; shake (one's head) (R+CONT+FREQ$+\mathrm{CONT}+\mathrm{INF}$ )' $-\check{s}$ on $+a+l t+y+n y$ 'to wave; shake (one's head) (once) (R+CONT+MOM+SEMF+INF).

\begin{tabular}{|c|c|c|c|}
\hline Finnish & Udmurt & English & AST \\
\hline \multicolumn{4}{|c|}{ 1. States: classifying predicative sentences } \\
\hline $\begin{array}{l}{[\text { Tyttö] }]_{\text {SUBJ/A }} \mathrm{O}+\mathrm{n}} \\
\text { girl.NOM be+PRES.3SG } \\
\text { kaunis. } \\
\text { beautiful }\end{array}$ & $\begin{array}{ll}{[\mathrm{Nyl}]_{\mathrm{SUBJ} / \mathrm{A}}} & \text { ćeber. } \\
\text { girl.NOM } & \text { beautiful }\end{array}$ & $\begin{array}{l}\text { 'A/The girl } \\
\text { is beautiful.' }\end{array}$ & $\begin{array}{l}\text { 1-place } \\
\text { predicate } \\
\mathrm{A}=\text { thema }\end{array}$ \\
\hline \multicolumn{4}{|c|}{ 2. Activities: sentences sensory predicates } \\
\hline $\begin{array}{l}\text { Poika }]_{\mathrm{SUBJ} / \mathrm{A}} \\
\text { boy.NOM } \\
\text { kuu+ntel+i. } \\
\text { listen+FREQ+PAST.3SG }\end{array}$ & $\begin{array}{l}{[\mathrm{Pi}]_{\mathrm{SUBJ} / \mathrm{A}}} \\
\text { boy.NOM } \\
\text { kylzi+śk+i+z. } \\
\text { listen+REFL- PASS+PAST-+3SG }\end{array}$ & $\begin{array}{l}\text { 'The boy was } \\
\text { listening.' }\end{array}$ & $\begin{array}{l}\text { 1-place } \\
\text { predicate } \\
\mathrm{A}=\text { experiencer }\end{array}$ \\
\hline \multicolumn{4}{|l|}{ 3. Achievements } \\
\hline $\begin{array}{l}(\operatorname{mies} \text { men }+\mathrm{i} \quad \text { ja) } \\
\text { man go+PAST.3SG and } \\
\text { löys }+\mathrm{i} \quad \text { [se }+\mathrm{n} \\
\text { find }+ \text { PAST.3SG that }+ \text { GEN } \\
\text { vaimo+nsa }]_{\mathrm{OBJ} / \mathrm{A} 2} \\
\text { wife+PX.3SG }\end{array}$ & $\begin{array}{l}\text { (myn+em no) šett+em } \\
\text { go+PERF.3SG and) find+PERF.3SG } \\
\text { [so kyšno+z+e] }]_{\text {OBJ/A2 }} \\
\text { that wife+PX.3SG+ACC } \\
\text { (Wichmann 1954: 25) }\end{array}$ & $\begin{array}{l}\text { "(the man went) } \\
\text { and find that his } \\
\text { wife." }\end{array}$ & $\begin{array}{l}\text { 2-place } \\
\text { predicate } \\
\text { A1 = experi- } \\
\text { encer } \\
\text { A2 = theme }\end{array}$ \\
\hline \multicolumn{4}{|c|}{ 4. Two- and three-place accomplishments (and activities) } \\
\hline $\begin{array}{l}{[\text { Pankki }]_{\text {SUBJ/A1 }}} \\
\text { bank.NOM } \\
\text { raho+itt }+\mathrm{i} \\
\text { finance+CAUS+PAST.3SG } \\
{[\text { yritykse+n }} \\
\text { firma }+ \text { GEN } \\
\text { toiminna }+ \text { n/ toiminta }+ \text { a }]_{\mathrm{OBJ} / \mathrm{A} 2} \\
\text { work+GEN/ work+PTV }\end{array}$ & $\begin{array}{l}\text { [Bank] suBJ/A2 } \\
\text { bank.NOM } \\
\text { [predpijatije+leś } \\
\text { firma+ABL } \\
\text { už+z+e }]_{\mathrm{OBJ} / \mathrm{A} 2} \\
\text { work+ACC } \\
\text { finanśirova+t' } \\
\text { finance+INF } \quad \text { do }+\mathrm{i}+\mathrm{PAST}+3 \mathrm{SG}\end{array}$ & $\begin{array}{l}\text { 'The bank fi- } \\
\text { nanced the work } \\
\text { of the enter- } \\
\text { prise.' }\end{array}$ & $\begin{array}{l}\text { 2-place } \\
\text { predicate } \\
\text { A1 = agent, } \\
\text { A2 = theme/ }\end{array}$ \\
\hline
\end{tabular}

TABLE 1. Examples of semantic sentence types in Finnish and Udmurt. ${ }^{2}$

\footnotetext{
${ }^{2} \mathrm{~A}=$ argument, $\mathrm{ABL}=$ ablative, $\mathrm{ACC}=$ accusative, $\mathrm{ADVL}=$ adverbial, $\mathrm{ALL}=$ allative, $\mathrm{AST}=$ argument structure type, CAUS $=$ causative, $+/$-CLSD $=+/$-closed, CONT $=$ continuous, DAT $=$ dative, $\mathrm{F}=$ facultative NP, FREQ $=$ frequentative, $\mathrm{GEN}=$ genitive, $\mathrm{IMP}=$ imperative, $\mathrm{INF}=$ infinitive, $\mathrm{INTR}=$ interrogative particle, $\mathrm{MOM}=$ momentary,
} 
Semantic properties of the derived forms are based on lexicalization processes, and also basic lexical semantic properties of the verbs: derivation can change the type of the aspect of situation expressed with the verbs. In Udmurt, there are some semantic restrictions concerning possibilities to combine derivational suffixes (cf. $p o n+y+n y$ : * $p o n+y+l$ 'l' $+a+n y$ 'to put, place, set; to stand'; Suihkonen, Zagulyayeva \& Tronina 2004 [1995]). Also in Finnish, possibilities to apply derivational processes are lexically restricted.

The semantics of predicate determines the basic argument structure of the situation types. Each of the four classes of types of situation included in Vendler's classification (Table 1) (or three: states, processes, and events) contains a lot of variety that is based on inherent semantics of predicates. In the first example, quantifying adverbials are not accepted: *a girl is beautiful all the time/three times/often. The sentences with sensory predicates can be interpreted as a process or an event, and the acceptability of the adverbial is dependent on the interpretation. In example 3, there is a typical achievement predicate, and only countable adverbials are accepted. Example 4 represents accomplishment sentences: case marking in the Finnish example tells if the activity is completed or not.

At least some quantifying adverbials are opaque in the way that they can be interpreted as predicate or sentential adverbials (cf. Cinque 1999: 25-28). In the sentence below, the scope of the countable quantifying adverbial kolmesti 'three times' ranges over the VP and the S:

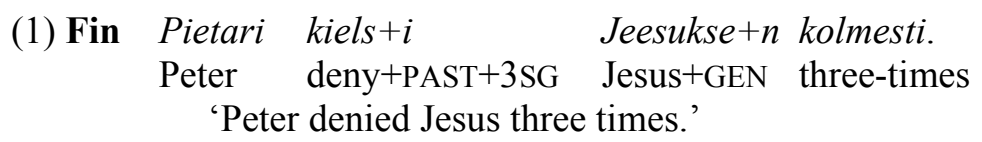

$\mathrm{S}[\mathrm{NP}[$ Peter] VP[denied Jesus three-times] $\mid \mathrm{S}[\mathrm{NP}[$ Peter] VP[denied Jesus] AP[three-times]]

The same rules can be found in Udmurt (PC, Leonid Ivšin; example (2)). It will be shown in this paper that acceptability of the adverbial type is dependent on the closure of the aspect. When a countable quantifying adverbial is interpreted as a sentential one, iterative/frequentative derivational suffixes are not accepted in the predicate (cf. (1')). Non-countable adverbials which stress and extend continuative properties of the predicate having a frequentative derivational suffix are accepted (example (3)).

(1') Pietari kiels $+i / * k i e l t+e l+i$ Jeesukse $+n$ kolmesti.

(2) Udm Kyd'ok+yn, busy šor+yn, t'uragaj kyrdz'a

far-off+INE, field+SG.NOM centre+INE, lark.SG.NOM sing.PRES.3SG

(UHLCS, Konovalov) *(ukmis pol 'nine times')

'Far off, in the centre of the field, a lark is singing (literally: sings, continuously) *(nine times).'

$\begin{array}{llll}\text { (3) Fin } & j a \quad \text { sano } & \text { itse, sopi+i+ko arvo }+l l e+n i & h y p+e l+l a ̈ \\ \text { and say.IMP } & \text { self be-befitting }+3 \mathrm{SG}+\mathrm{INTR} \text { dignity }+\mathrm{ALL}+1 \mathrm{SG} \text { jump+FREQ } \\ o j+i+e n & y \text { litse (UHLCS, Waltari); (...jatkuvasti 'continuously') } \\ \text { ditch+PL+GEN over } & \\ \text { 'and say yourself, if it is with dignity proper to my rank jumping over ditches,' }\end{array}$

The hypothesis is that sentence and predicate level quantifying adverbials can be accepted, when they both represent the same semantic type with respect to the closure of the aspect of the sentence. In Finnish, the change of the closure of the aspect type is marked in the case marking of the obligatory arguments. In Udmurt, the division of predicates into two conjugational classes is the main method used in creating the opposition between countable and non-countable eventualities. A basic division characterizing derivational suffixes can be done on the basis their ability to change the closure of aspect. Quantification will be investigated within the framework of the theory of Generalized Quantifiers (cf., e.g., Keenan 1996). The greatest part of the data to be investigated is collected from the

$\mathrm{NOM}=$ nominative, $\mathrm{NP}=$ noun phrase, $\mathrm{OBJ}=$ object, $\mathrm{PAST}=$ past, $\mathrm{PERF}=$ perfect, $\mathrm{PL}=$ plural, $\mathrm{PRES}=$ present, $\mathrm{PRG}=$ progressive, $\mathrm{PTV}=$ partitive, $\mathrm{PX}=$ possessive suffix, $\mathrm{R}=$ root, $\mathrm{REFL}-\mathrm{PASS}=$ reflexive-passive, $\mathrm{S}=$ sentence, $\mathrm{SEMF}=$ semelfactive, $\mathrm{SG}=$ singular, $\mathrm{SUBJ}=$ subject, $*=$ ungrammatical. 
computer corpora of Finnish and Udmurt located at the University of Helsinki Corpus Server (UHLCS; cf. http://www.ling.helsinki.fi/uhlcs/).

\section{REFERENCES}

CinQue, Guglielmo. 1999. Adverbs and Functional Heads. A Cross-Linguistic Perspective. Oxford Studies in Comparative Syntax. New York and Oxford: Oxford University Press.

COMrIe, Bernard. 1976. Aspect. An Introduction to the Study of Verbal Aspect and Related Problems. Cambridge Textbooks in Linguistics. Cambridge University Press. Cambridge.

DowTY, DAVID. 1979. Word Meaning and Montague Grammar. The Semantics of Verbs and Times in Generative Semantics and in Montague's PTQ. Synthese Language Library 7. Dordrecht: D. Reidel Publishing Company.

GrimshaW, JaNE. 1994. Argument Structure. Linguistic Inquiry, Monograph Eighteen. Cambridge, Massachusetts: The MIT Press.

KeEnAN, EDWARD L. 1996. The Semantics of Determiners. In Lappin, Shalom (ed.), The Handbook of Contemporary Semantic Theory, 39-63. Oxford: Blackwell Publishers.

PARTEE, BARBARA. 1995. Quantificational Structures and Compositionality. In Bach, Emmon, Eloise Jelinek, Angelika Kratzer, \& Barbara H. Partee (eds.): Quantification in Natural Languages II. Studies in Linguistics and Philosophy 54, 541-601. Dordrecht: Kluwer Academic Publishers.

Suihkonen, PirkKo, Bibinur ZagulyayeVA, and Galina TroninA. 2004 [1995]. UdmurtEnglish-Finnish Dictionary with a Basic Grammar of Udmurt. Lexica Societatis FennoUgricae XXIV. Suomalais-Ugrilainen Seura. Helsinki. Revised and completed version in preparation.

SUIHKONEN, PIRKKO. 2003. On the semantics of quantification and case marking in Finnish. In Suihkonen, Pirkko \& Comrie, Bernard (eds.) with the assistance of Sergej Anatol'evič Maksimov. International Symposium on Deictic Systems and Quantification in Languages Spoken in Europe and North and Central Asia. Udmurt State University, Izhevsk, Udmurt Republic, Russia, May 21-24, 2001. Collection of papers, 32-41. Udmurt State University, Izhevsk, and Max Planck Institute for Evolutionary Anthropology, Leipzig. In print.

TENNY, CAROL, and JAMES PusteJOVSKY. 2000. History of Events in Linguistic Theory. In Tenny, Carol, \& James Pustejovsky (eds.): Events as grammatical objects: the convergence perspectives of lexical semantics and syntax. CSLI Lecture Notes 100, 3-37. Stanford: CSLI Publications.

VAN VALIN, ROBERT D.JR. and RANDY J. LAPOLLA. 1997. Syntax: structure, meaning and function. Cambridge textbooks in linguistics. Cambridge: Cambridge University Press.

VENDLER, ZENO. 1967. Linguistics in philosophy. Ithaca (NY): Cornell University Press.

WICHMANN, YRJÖ (1954). Votjakische Chrestomathie mit Glossar. Hilfsmittel für das Studien der finnisch-ugrischen Sprachen 


\title{
IDEOPHONES AS DEPICTIVE SECONDARY PREDICATES
}

\author{
MARIA TOLSKAYA \\ Holliston, USA
}

The paper is based on the analysis of depictive secondary predicates proposed by Eva SchultzeBerndt \& Nikolaus P. Himmelmann in (Himmelmann 2003). In their thorough investigation a crosslinguistically applicable definition of the genuine depictive construction is introduced and criteria of depictiveness are suggested. I would like to consider in this perspective data from Udeghe, a Manchu-Tungusic language, in which secondary predication is widespread. In this connection, one observation in (Himmelmann 2003) attracts special attention:

It is to be expected that uninflecting predicates ... in depictive function can also be found outside the Northern Australian area. Potential candidates are some types of those uninflecting elements variously known as ideophones, "expressives" or "sound-symbolic adverbs", found e.g. in many African languages. (p. 37)

The prediction, made for African languages, might prove to be also for Udeghe, a Manchu-Tungusic language with a striking amount of ideophones. My aim is to provide evidence from Udeghe in support of this hypothesis, and to investigate what properties of ideophones make them typical lexical fillers for depictives.

The examples come from our field materials, recently published (in this case reference is not provided) and from the following sources: (Kormushin 1998), (Simonov et al. 1998), (Kanchuga 2002) and (Kjalundzjuga 1998-1999). Although Udeghe is represented by two main dialects, the divergences between them with respect to the phenomena in question are not significant. The analysis is consistent with the theoretical framework used in A Grammar of Udihe (Nikolaeva 2000).

Ideophones are a large and distinctive, though not uniform class of words, which create a figurative image related to visual, audible or tactile impressions, and not necessarily by sound-poetic means. They form a specific lexical subsystem with phonetic peculiarities such as presence of marginal consonant / $\mathrm{r}$, expressive lengthening of final /i/ or sonorant or, on the contrary, drop of final vowel. Most of them are not derived from a synchronic point of view, although there are several productive patterns, including reduplication. We are concerned with ideophones ending in $-r$ (like puniar, rendering the impression of the smoke rising over a traditional dwelling, seen from a distance), -li (like lumbulili 'impression of waving long tail or hair'), -'oi (like mogz'oi 'naked') and - $m$ (like jolom 'ajar'), which seem to be used as genuine depictives.

In Udeghe, not only ideophones can function as depictive elements, and, on the other hand, ideophones have also other grammatical tasks besides involvement in depictive constructions, but they share a number of semantic, syntactic and prosodic characteristics with depictives:

1) The two major syntactic functions of Udeghe ideophones are (i) verbal modifiers, and (ii) components of compound adjectives that are mostly used in the predicative position. This allows them to be used as secondary predicates, specifically as depictives, which are assumed to participate in two overlaping independent relationships: (i) between the depictive and the main predicate (adjunction) and (ii) between the depictive and its controller (predication).

2) Ideophones do not have morphological verbal properties, though some of them are probably derived from ideophonic verbs not preserved in the modern language. It makes them candidates for depictive status, since depictives are required not to be marked for tense or mood categories.

3) The common feature of ideophones and depictives is their optionality, that is, both can be omitted without changing the structural relationships, although the text will lose much in expressiveness:

$$
\begin{array}{ll}
\begin{array}{l}
\text { Kasanziga [bombolie] } \\
\text { puppy tukia-wasi:-ti. }
\end{array} & \text { round } \\
\text { run-DIV-3SG }
\end{array}
$$

'Puppies are running around, [(like) little balls].' (Simonov, 456) 
This delimits them from constructions with "semantically bleached" predicates, such as bagdi- 'live, grow', isepte- 'seem, look', te:- 'sit', which are very close to copulas. In the following example the depictive ideophone $c a: m$ cannot be dropped:

$$
\begin{array}{llll}
\text { Uli xe:-ni, } & \text { sugzia } & \text { ca:m } & \text { ise-pte. } \\
\text { river bottom-3SG } & \text { fish } & \text { white } & \text { look-DEC } \\
\text { 'River bottom and fish seem white.' (Kanchuga) }
\end{array}
$$

4) Since Udeghe requires preverbal position of the focus element, which is highlighted by a high pitch intonation, preverbal position of this group of ideophones and their failure to adhere to the Udeghe phonotactics clearly mark them as focused elements. Depictives, in their turn, are inherently focused, which is supported by their prosodic characteristics: a separate pitch accent and individual intonational domains (Winkler 1997).

5) Depictives are restricted with respect to semantics and most frequently encode a physical or psychological state or condition, including bodily posture (e.g. 'upright', 'sitting', 'barefoot', 'with one's mouth open'). The same range of meanings, especially the states which can leave visual, audible or tactile impressions, is typical for ideophones. A few ideophones form compound idiomatic expressions with the word denoting body parts: dili 'head', igi 'tail', bugdi 'legs', ja: 'eyes'. These are, e.g. ja: bugdam 'with goggled eyes', ja: pam 'with black eyes' (from anger), ja: kilum 'with suspicious eyes', igi kicom 'with tail up', dili gingom 'with head up'. Such compound depictives can be subjector object-controlled. The noun, denoting the body part, may be dropped (let us note, this noun is not depictive controller in this construction).

$$
\begin{aligned}
& \text { Meiexi kialani [(igi) lumbulilie] sul'ai tukia:-ni. } \\
& \text { M. near tail waving fox run.PAST-3SG } \\
& \text { 'A fox with [a waving tail] ran past Meiexi.' (Simonov, p.524) }
\end{aligned}
$$

Udeghe formally distinguishes depictives from other semantically depictive constructions, such as adverbials or resultatives, but this requires special investigation. Thus, although depictive ideophones and adverbials are restricted to different syntactic environments (depictive ideophones characterise a subject or object participant and modify a noun phrase, whereas adverbials modify the verb) this distinction is not always clear-cut. This difference is indirectly shown by the fact that depictive ideophones, like depictive adjectives, express Plural agreement with the controller, while adverbs are never morphologically marked for the Plural. The following examples demonstrate different strategies for plural marking, used in depictive adjectives (-ngku) and depictive ideophones (zigA):

$$
\begin{aligned}
& \text { Nuati zo:ngku-ngku-zi bagdi:-ti. } \\
& \text { they poor-PL-INST live-3PL } \\
& \text { 'They live poorly.' } \\
& \text { Exe-zege bigzam-ziga xetigesi-li-e-ti. } \\
& \text { frog-PL bow-legged-PL jump-INH-PAST-3PL } \\
& \text { 'The frogs started jumping bow-legged.' (Simonov p.167) }
\end{aligned}
$$

The subject and the object control number agreement on the depictive adjective, but the controller does not have to be an overtly expressed argument of the main predicate, cf. the controllerless objectoriented depictive in plural bokchom-ziga 'tied, in crooked position':

$$
\begin{aligned}
& \text { A:na xe:-le-ni wentegi-e-ni } \quad \text { o:-ti } \\
& \text { boat bottom-LOC-3SG throw-PAST-3SG do.PAST-3PL crooked-PL } \\
& \text { '(The enemies) threw (them) crooked on the bottom of a boat.' }
\end{aligned}
$$

Apart from the accusative direct object, in Udeghe the patient/theme argument may be encoded by the destinative object, marked by the destinative case and the possessive affix. The head noun denotes an object designated for a particular person (benefactive) or purpose. Like a regular direct object, the destinative object can control copredicates. However, this destinative- 
controlled copredicative construction is semantically ambiguous, since it allows both depictive and resultative readings, which follows from semantics of the main predicate (it is a transitive verb of transition, and creation, such as gada-'buy', uli-'sew', ule-'dig', olokto- 'cook' and wo:-'make, build', in contrast to the genuine depictive predicates). The fact that ideophones almost never occur in sentences with destinative object argues in favour of their resultative reading. Depictive adjectives with instrumental marking are used instead:

$\begin{array}{llll}\text { Tuxi-we } & \text { o:-mi, Ilige-ne-ni } & \text { guigda-zi } & \text { o:. } \\ \text { sledge-ACC } & \text { make-INF (a part of the sledge)-DEST-3SG } & \text { high-INSTR } & \text { make.PRP } \\ \text { 'Making a sledge, they make a certain part of it high.' (Simonov p. 248) } & \end{array}$

I will conclude by arguing that the class of ideophones in question is used almost exclusively as depictives. They may not be used as attributes, but only as predicates, with or without a copula, and their prototypical function is copredicative.

\section{REFERENCES}

SChultze-Bernd, E. and N. P. Himmelmann. Depictive secondary predicates in cross-linguistic perspective. To appear in Linguistic Typology. www.linguistics.ruhr-unibochum.de/ himmelmann/Depict 1t.pdf.

KanchugA, A. A. 2002. A Udehe autobiographical text with Russian Translation (edited by Toshiro Tsumagari) Kyoto: Endangered Languages of the Pacific Rim Publications.

KoRMUŠIN, I. V. 1998. Udyhejskij (udegejskij) jazyk: Materialy po ètnografii. Očerk fonetiki $i$ grammatiki. Teksty i perevody. Slovar'. [The Udihe (Udeghe) language. Materials on the ethnic culture. A sketch of phonetics and grammar. Texts and translations. Glossary]. Moscow: Nauka.

NikolaeVA, I. and M. Tolskaya. 2001. A grammar of Udihe. Berlin: Mouton de Gruyter.

Nikolaeva, I., E. PereKhVAlsKaya, and M. TolskayA. 2003. Udeghe (Udihe) texts. Kyoto: Endangered Languages of the Pacific Rim Publications.

Nikolaeva, I., Perekhvalskaya, E. and M. Tolskaya. 2002. Udeghe (Udihe) folk tales. Tunguso-Sibirica 10. Wiesbaden: Otto Harrassowitz.

Simonov, M. D., KJalundzJuga, V. T. and M. M. XASANOVA. 1998. Fol'klor udegejcev. Nimanku, telungu, jexe. [The folklore of the Udihe. "Nimanku", "Telungu", "Jexe"]. (Pamjatniki fol'lkora narodov Sibiri i dal'nego Vostoka). Novosibirsk.

WINKLER, SUSANNE. 1997. Focus and Secondary Predication. Berlin, New York: Mouton de Gruyter. 


\title{
PARTITIVE CASE IN ESTONIAN AN ANALYSIS BY WAY OF MACROROLES
}

\author{
VIRVE VIHMAN \\ University of Edinburgh, Theoretical and Applied Linguistics, Edinburgh
}

This paper presents a unified analysis of partitive case-marking in Estonian using the notion of macroroles, as employed in Role and Reference Grammar (RRG, Van Valin \& LaPolla 1997). The partitive case has been described as a default object-marking case in both Finnish and Estonian (Sulkala 1996:170, Tauli 1968:216, Heinämäki 1984). It marks 'partial objects', signalling primarily partiality and low transitivity (related to but not limited to partial affectedness of the object, Helasvuo 1996), and it alternates with an abstract 'accusative' total object case (realised as either nominative or genitive, Hiietam 2002).

The fact that partitive case marks low transitivity can be called upon to partially account for a few facts about Estonian grammar, such as the following:

- While 'total objects' are marked with nominative case in the absence of an overt nominative subject, as in impersonal and imperative clauses, partial objects are consistently marked with partitive case, e.g. in impersonals and imperatives.

- Partitive case marks non-canonical 'subjects' in existential clauses. These clauses involve intransitive verbs and are low in transitivity (à la Hopper \& Thompson 1980), expressing the existence of something in a locative or temporal space and representing a state, not an action (Sands \& Campbell 2001: 263).

However, this explanation does not account for the differential behavior of partitive objects among predicates which only assign partitive case, as shown in examples (1) and (2).

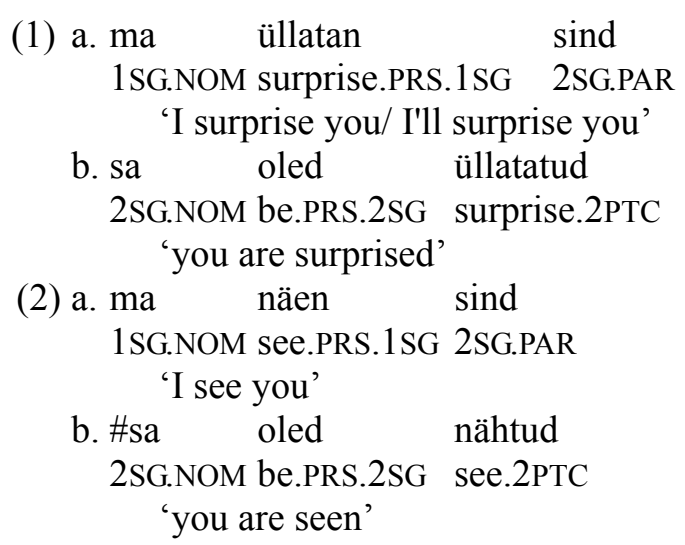

The verbs in these examples both only take partitive objects. Personal passivisation promotes even partitive objects to full subjects, but it does not apply equally to these two predicates. While (1b) shows that the passive counterpart of (1a), with üllatama 'surprise', is natural and grammatical, the passive of (2a) requires a very particular interpretation, acquiring semantics unrelated to the active clause. Example (2a) would be understood to mean "you are caught", rather than the stative "you are seen". Rajandi (1999) also mentions examples like that repeated in (3), of transitive verbs with human subject referents which can be impersonalised (as in 3a) but not passivised (3b).

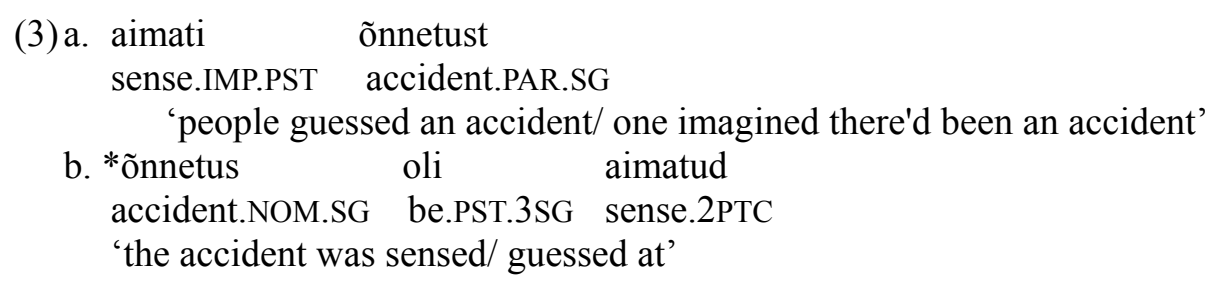


There is no explanation for why this verb is ungrammatical in the personal passive in Rajandi (1999). However, these facts fall out of an analysis using macroroles with no further stipulation: the puzzle of bivalent verbs which cannot be passivised is easily explained by the theory of macroroles.

Semantic macroroles derive from the assumption that thematic roles can be ordered in a hierarchical continuum. The RRG notion of transitivity reflects the number of macrorole arguments a verb takes. Verbs can have a maximum of two macrorole (MR) arguments, the generalised actor MR and the generalised undergoer MR. The actor MR includes semantic roles on the agentive side of the thematic role hierarchy (such as agent, experiencer, instrument), while the undergoer MR covers patientive roles (such as patient, theme, recipient). Macrorole selection is based on the logical structures of verbs, which can include zero, one or two macroroles.

Not all core arguments have macrorole functions. The maximum number of macroroles a predicate can have is two, namely the actor and the undergoer. Just as there are verbs which take one syntactic argument which is not a macrorole (e.g. English rain), so are there also verbs which have two core arguments, both syntactic and semantic, yet only one macrorole argument.

An example of this relation between logical structure and the number of macroroles is a verb like eat, which in many languages can take either one or two core arguments. In Estonian, its second core argument also exhibits case alternation. Importantly, the object argument of eat has been claimed not to always fill a macrorole. This verb has both variable transitivity and variable Aktionsart, e.g. in Italian and Estonian. The bivalent form of eat can align itself with either transitive or intransitive predicates in terms of syntactic behavior, and this is crucial for macrorole allocation and valency operations. Van Valin \& LaPolla claim that "the majority of activity verbs, regardless of how many arguments they have, take no more than one macrorole" (1997:153). The Estonian data fits this generalisation, tying in with partitive object marking.

The second argument of the activity predicate when it is not assigned a macrorole function is an inherent argument: it "serves to characterize the action rather than pick out any of the participants... If it does not refer to any specific participant in a state of affairs, it cannot be an undergoer" (1997:149). The partitive object is lower in transitivity and sometimes does not fill a macrorole function, serving merely to characterise the activity rather than denoting an independent object affected by the activity.

An object with undergoer MR status is licensed for more syntactic object-related operations than one without MR status. Personal passivisation in Estonian is one of the syntactic operations that require an undergoer MR object. This explains the different behaviour under passivisation of the object of nägema 'see' and üllatama 'surprise', in examples (1-2). Nägema 'see' - a stative verb - does not assign MR status to its object. If that object is promoted to subject in a personal passive, the aspectual class of the predicate is forced to change, as the object of stative nägema is simply not available for passivisation. The object is coerced into a macrorole status (and hence, a higher-transitivity affected undergoer semantic role) by the simple operation of being promoted through passivisation. The object of üllatama 'surprise', on the other hand, is available for passive promotion. This is an achievement verb which assigns affected undergoer MR status to its patient.

The explanation using MRs also accounts nicely for the ungrammaticality of the personal passive in (3). It is not only variable verbs like sööma 'eat', but also invariable bivalent verbs with only one MR (nägema, aimama), which do not allow passivisation. The verb in (3), aimama 'guess at, divine', clearly does not have a semantically affected patient. This non-affected object, in turn, does not have MR status, and hence is unavailable for passive promotion to subject. The macrorole explanation is entirely compatible with the general facts about partitive case as well as the idiosyncratic facts mentioned above. It derives from semantic explanations using the scalar notion of transitivity, but, as this paper shows, it is more powerful than previous semantic explanations have proved to be.

\section{REFERENCES}

HEINÄMÄKI, O. 1984. Aspect in Finnish. In C. de Groot \& H. Tommola, eds., Aspect Bound: A voyage into the realms of Germanic, Slavonic, and Finno-Ugrian aspectology, 153-177. Foris Publications: Dordrecht.

HelaSvUO, M.-L. 1996. A discourse perspective on the grammaticization of the partitive case in Fin- 
nish. In T. Haukioja, M.-L. Helasvuo \& E. Kärkkäinen, eds. SKY 1996. Linguistic Association of Finland: Helsinki.

HIIETAM, K. 2002. On definite object marking in Estonian. Paper presented at the Linguistics Association of Great Britain Meeting, UMIST, Manchester.

HOPPER, P.J., and S.A. THOMPSON. 1980. Transitivity in grammar and discourse. Language 56, 251299.

RAJANDI, H. 1999 (orig. 1968). Eesti impersonaali ja passiivi süntaks [The syntax of the Estonian impersonal and passive]. Eesti Keele Instituut: Tallinn, Estonia.

SANDS, K., and L. CAMPBELL. 2001. Non-canonical subjects and objects in Finnish. In A.Y. Aikhenvald, R.M.W. Dixon \& M. Onishi (eds.), Non-Canonical Marking of Subjects and Objects. John Benjamins: Amsterdam.

SulKalA, H. 1996. Expression of aspectual meanings in Finnish and Estonian. In M. Erelt, ed., Estonian: Typological Studies I, 165-225. Tartu, Estonia: Department of Estonian at the University of Tartu.

TAULI, V. 1968. Totaalobjekt eesti kirjakeeles [The total object in written Estonian]. Suomalaisugrilaisen Seuran Toimituksia, 216-224.

VAN VAlin, R.D., and LAPOLLA, R.J. 1997. Syntax: Structure, meaning and function. Cambridge University Press: Cambridge. 


\title{
ON THE ERGATIVE RECIPROCAL TSOTSAZ CONSTRUCTION IN STANDARD AVAR*
}

\author{
HISANARI YAMADA \\ University of Tokyo, Japan
}

When the transitive $\mathrm{A}$ and $\mathrm{O}$ stand in a reciprocal relation, standard Avar uses the construction with the ergative free-standing reciprocal pronoun tsotsaz in the A position and its antecedent in the $\mathrm{O}$ position. This configuration will be referred to in what follows as the ergative reciprocal tsotsaz construction. This is illustrated in (1). ${ }^{1}$

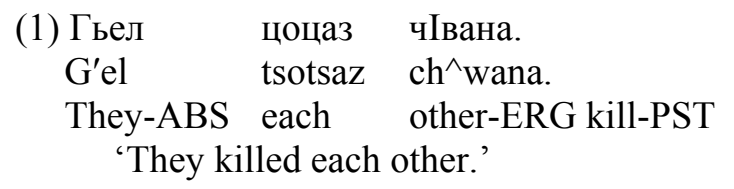

Avar is one of Daghestanian (Northeast Caucasian) languages and it is spoken mainly in the Republic of Daghestan in the Russian Federation and in the Republic of Azerbaijan. Avar exhibits the absolutive-ergative case marking pattern: The intransitive $\mathrm{S}$ and the transitive $\mathrm{O}$ are marked with the absolutive case, whereas the transitive A is marked with the ergative case. In (1) an absolutive NP $g^{\prime} e l$ antecedes an ergative reciprocal tsotsaz. The standard Avar reciprocal pronoun tsotsa- does not use the absolutive form, and therefore standard Avar does not have the construction in which the ergative NP antecedes the absolutive form of the reciprocal tsotsa-. The aim of this presentation is to show that the ergative reciprocal tsotsaz construction is not transitive but intransitive. In this respect this construction is similar to the Romance reflexive clitic construction, which is discussed by many scholars (Grimshaw 1982, etc.). Two arguments for the intransitive analysis of the ergative reciprocal tsotsaz construction are presented. The first argument is provided by the case marking in the causative construction. The intransitive $\mathrm{S}$ embedded under the causative verb $g^{\prime} a$-AM-ize appears in the absolutive case, whereas the embedded transitive A occurs in the first locative case and the transitive $\mathrm{O}$ takes the absolutive case, as is exemplified in (2) and (3).

\begin{tabular}{|c|c|c|c|c|}
\hline (2) Мусаца & ГІали & \multirow{2}{*}{$\begin{array}{l}\text { ьедезе } \\
\text { l"edeze }\end{array}$} & \multicolumn{2}{|c|}{ гьавуна. } \\
\hline Musatsa & $\mathrm{G}^{\wedge}$ ali & & & \\
\hline $\begin{array}{l}\text { Musa-ERG } \\
\text { 'Musa m }\end{array}$ & Ali-ABS tc & swim-INI & Fmake-PS & \\
\hline (3) Мусаца & ГІалида & ГІиса & чЈвазе & гьавуна. \\
\hline Musatsa & $\mathrm{G}^{\wedge}$ alida & $\mathrm{G}^{\wedge}$ isa & $\mathrm{ch}^{\wedge}$ waze & g'awuna. \\
\hline Musa-ERG & Ali-LOC1 & Isa-ABS & to kill & make-PST \\
\hline
\end{tabular}

When a clause with a reciprocal in the A position and its antecedent in the $\mathrm{O}$ position is embedded in a causative construction, the reciprocal is marked not with the first locative but with the ergative case and its antecedent stands in the absolutive case, as is illustrated in (4).

$\begin{array}{cllll}\text { (4) Мусаца } & \text { гьел } & \text { цоцаз } & \text { чІвазе гьаруна. } \\ \text { Musatsa } & \text { g'el } & \text { tsotsaz } & \text { ch }^{\wedge} \text { waze } & \text { g'aruna. } \\ \text { Musa-ERG } & \text { they-ABS } & \text { each other-ERG } & \text { to kill-INF } & \text { make-PST } \\ \text { 'Musa made them kill each other.' } & & \end{array}$

This fact is explained by the intransitive analysis of the ergative reciprocal tsotsaz construction. The second argument for the intransitive analysis of the ergative reciprocal tsotsaz construction comes from case marking of arguments of the verb embedded under the verb l"ug'ine 'to begin'. The verb

\footnotetext{
${ }^{1}$ ABREVIATIONS: ABL1 = first ablative case, $\mathrm{ABS}=$ absolutive case, $\mathrm{AM}=$ agreement marker, $\mathrm{ERG}=$ ergative case, $\mathrm{INF}=$ infinitive, $\mathrm{LOC} 1=$ first locative case, $\mathrm{PST}=$ past tense.
} 
l"ug'ine 'to begin' takes an infinitive complement. With the verb l"ug'ine 'to begin', the embedded $\mathrm{S}$, $\mathrm{A}$, and $\mathrm{O}$ all stand in the absolutive case, as is shown in (5) and (6).
(5)ГІали
лъедезе
лъугьана.

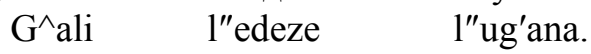

Ali-ABS to swim-INFto begin-PST

'Ali began to swim.'
(6)ГІали ГІиса веццизе льугьана.
$\mathrm{G}^{\wedge}$ ali $\quad \mathrm{G}^{\wedge}$ isa wetstsize 1"ug'ana.
Ali-ABS Isa-ABS to praise-INF to begin-PST
'Ali began to praise Isa.'

When the verb l'ug'ine 'to begin' takes an infinitive complement with a reciprocal in the A position and its antecedent in the $\mathrm{O}$ position, the reciprocal take not absolutive but ergative case and its antecedent stands in the absolutive case, as is exemplified in (7).
(7) Гьел
цоцаз
tsotsaz
реццизе
льугьана.
They-ABS
each other-ERG
retstsize
1"ug'ana.
'They began to praise each other.'

This fact supports the intransitive analysis of the ergative reciprocal tsotsaz construction. This presentation additionally shows that the ergative reciprocal tsotsaz does not lose a slot in the syntax and it is demoted to the oblique function. In this respect, there is a difference between the standard Avar ergative reciprocal tsotsaz and the Romance reflexive clitic, which is argued to have no position in the syntax (Grimshaw 1982 etc.). Zec (1985) uses the comparative construction as the evidence that the Serbo-Croatian reflexive clitic has no position in the syntax and many studies uses her test for the analysis of the Romance reflexive clitic (Alsina 1996 etc.). In the ergative reciprocal tsotsaz construction, the ergative reciprocal tsotsaz can be the object of comparison, as is illustrated in (8).

$\begin{array}{clll}\text { (8)Гьел } & \text { дидаса } & \text { цоцаз } & \text { реццана. } \\ \text { G'el } & \text { didasa } & \text { tsotsaz } & \text { retstsana. }\end{array}$

They-ABS I-ABL1 each other-ERG to praise-PST

'They praised each other more than me.'

This fact supports the conclusion that the ergative reciprocal tsotsaz has a position in the syntax.

\section{REFERENCES}

Alsina, ALEX. 1996. The Role of Argument Structure in Grammar: Evidence from Romance, Stanford, California: CSLI Publications.

GRIMSHAW, JANE. 1982. On the Lexical Representation of Romance Reflexive Clitics. In Joan Bresnan (ed.), The Mental Representation of Grammatical Relations, 87-148, Cambridge, Mass.: MIT Press.

ZeC, DRAGA. 1985. Objects in Serbo-Croatian. In Proceedings of the Eleventh Annual Meeting of the Berkeley Linguistics Society, 358-371. 


\title{
THE ROLE OF LEXICAL SEMANTICS IN UNACCUSATIVE-UNERGATIVE DISTINCTION IN TURKISH
}

\author{
DENIZ ZEYREK \\ Middle East Technical University, Ankara
}

One of the approaches to understanding argument structure, lexical semantics, and verbal alternations is to presume that verbs belong to distinct classes. I will deal with unaccusativity in Turkish in the spirit of this line of research. Following the lead of Levin \& Rappaport Hovav (1995), I will assume that unaccusativity is semantically determined but syntactically represented. Building on Levin and Rappaport-Hovav (1995) and the studies of Sorace and her colleagues (Sorace 1995, 2000, Keller \& Sorace 2003, Sorace \& Shomura 2001), I will argue that impersonal passivization, suggested as a diagnostic for unaccusativity (Perlmutter 1978, Ozkaragoz 1986, Nakiboglu 1998, among others) is sensitive to a thematic/aspectual hierarchy of verb classes, and adjectival passivization shows a split between core unaccusatives and core unergatives. I will propose that certain subsets of verbs manifest indeterminate behaviour, which is either attributable to compositional factors, or to eventstructure properties of verb classes. The data I will review will shed light on the semantic determinants of the single argument of intransitive verbs, which in turn will have implications for the argument structure of intransitive verbs.

The Auxiliary Selection Hierarchy (ASH) (Sorace 1995, 2000) is the basic framework of this study. It is a thematic/aspectual hierarchy based on the auxiliary selection properties of four Western languages. It maintains that certain intransitive verbs manifest 'core' unaccusativity, certain verbs exhibit core unergativity, while others are invariant in their syntactic behaviour. The behaviour of an intransitive verb is largely predictable from its position on the hierarchy (Figure 1).

Change of location

Change of state

Continuation of state

Existence of state

Uncontrolled process

Controlled process (motional)

Controlled proces (non-motional)

selects BE (least variation)

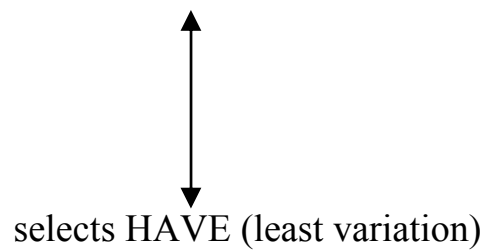

FIGURE1. Auxiliary Selection Hierarchy (ASH).

The ASH predicts that intra and crosslinguistically, native speaker judgements about core unaccusatives and core unergatives are categorical, while the judgements about the verbs close to the center are consistently unstable. According to the ASH, there is no language where the position of the verbs occupying the highest and the lowest positions is completely reversed. However, languages may make finer distinctions within individual classes represented on the ASH, merge verb classes, and may have different cut-off points along the hierarchy.

I will regard the ASH as a working hypothesis to analyse unaccusativity in Turkish. I believe that it is a legitimate starting point mainly because it predicts systematic variability in a verb's behaviour, which is the central motivation behind the semantic approach I am using here. Furthermore, it has been shown that acquisition studies do not fail to confirm the hierarchy's predictions (Sorace 1995, Sorace \& Shomura 2001).

I will limit the discussion to monadic verbs, leaving the verbs entering the causativeanticausative/inchoative pattern for further research (e.g. Kapiyi kapadim 'I closed the door'/Kapi kapandi 'The door was closed'. The results I will report on will be based on native speaker judgements ellicited informally.

I will first deal with impersonal passivization (IP) and propose that it is sensitive to agentivity and telicity. I will present data illustrating the fact that as the verbs appearing in IP are increasingly more agentive, the acceptability of the construction would increase. The acceptability of the IP construction would also increase when the telicity of the verb decreases. I will show that these observations are consistent with the predictions of the ASH. 
Nakiboglu-Demiralp (2001) has observed that IP is grammatical with some unaccusative verbs in the aorist, e.g. ol- 'die', dog - 'be born'; inducing a generic and an existential reading. She has suggested that this is due to variable verb behaviour, a phenomenon discussed by Rosen (1984) and many others. Building on this observation, I will show that variability extends to a larger number of verbs covering most verbs in the class of change of state verbs. I will propose that the indeterminacy of this class is attributable to compositional factors contributed by the grammatical context in which a verb appears (Pustejovsky 1995, Pustejovsky \& Busa 1995).

I will also touch on the behaviour of motion verbs, which are known to participate in eventshift alternations crosslinguistically. Similarly in Turkish, some telic and directional motion verbs (e.g. alcal 'descend') and all atelic and nondirectional ones (e.g. yuz 'swim', kos 'run') are sensitive to temporal adverbs and Path expressions. On the other hand, not all directional and telic verbs (i.e. the change of location class on the ASH) allow adjectival passivization. If adjectival passivization is a test for unaccusativity, it seems that pure path verbs like cik 'exit', gir 'enter', etc. would pose a problem for the ASH as they do not allow adjectival passivization. I will attempt to provide an explanation for this situation relying on the generalizations about verb-framed languages (Talmy 2000) and Slobin's (to appear) refinements of Talmy's generalizations. I will propose that Turkish merges change of location verbs with change of state verbs.

\section{REFERENCES}

LeVin, B. \& Hovav M. RAPPAPORT. 1995. Unaccusativity at the Syntax-Lexical Semantics Interface. Cambridge: MIT Press.

NAKIBOGLU, M. 1998. Split intransitivity and the syntax-semantics interface in Turkish. Unpublished $\mathrm{Ph}$.D. Dissertation, University of Minnesota.

NAKIBOGLU-DEMIRALP, M. 2001. The referential properties of the implicit arguments of impersonal passive constructions. In Erguvanli Taylan, E. (ed.), The Verb in Turkish. Amsterdam: Benjamins.

OzKaragoz, I. 1986. The relational structure of Turkish Syntax. Unpublished Ph.D. Dissertation, University of San Diego.

PerlmutTER, D. 1978. Impersonal passives and the unaccusative hypothesis. In A. C. Woodbury, F. Ackerman, C. Chiarelo, O. D. Gensler, J. J. Jaeger, J. Kingston, E. E. Sweetser, H.T. Thompson, and W.Whistler (eds.), Proceedings of the Fourth Annual Meeting of the Berkeley Linguistics Society, 157-189. Berkeley: University of California.

Pustejovsky, J. 1995. The Generative Lexicon. Cambridge: The MIT Press.

PUSTEJOVSKY, J. \& F. Busa. 1995. Unaccusativity and event composition. In P. M. Bertinetto, V. Bianchi, and M. S. Higginbotham (eds.), Temporal Reference, Aspect and Actionality, 1. Semantic and Syntactic Perspectives. 158-177.

Rosen, C. G. 1984. The interface between semantic roles and initial grammatical relations. In Perlmutter, D.M. and C. Rosen (eds.), Studies in Relational Grammar, 2. Chicago, Ill.: University of Chicago Press.

SLOBIN, DAN I. To appear. The many ways to search for a frog: Linguistic typology of the expression of motion events. In S. Stomqvist, and L. Verhoeren (eds.), Relating Events in Narrative: Typological and Contextual Perspectives. Mahwah, NJ: Lawrence Erlbaum Associates.

SORACE, A. 1995. Acquiring linking rules and argument structures in a second language. The unaccusative/unergative distinction. In Eubank, L., L. Selinker, and M. S. Sharwood (eds.), The Current State of Interlanguage. Amsterdam: Benjamins.

SORACE, A. 2000. Gradience in auxiliary selection with intransitive verbs. Language 76: 4, 859-890.

SORACE, A., and F. KELLER. 2003. Gradient auxiliary selection and impersonal passivization in German: An experimental investigation. Journal of Linguistics 39, 57-108.

SORACE, A., and Y. SHOMURA. 2001. Lexical constraints on the acquisition of split intransitivity. Evidence from L2 Japanese. Studies in Second Language Acquisition 23, 247-278.

TALMY, L. 2000. Toward a Cognitive Semantics. Cambridge: The MIT Press.

TENNY, C. 1994. Aspectual Roles and the Syntax-Semantic Interface. Kluwer Academic Publishers. 